Recharge Area, Base-Flow and Quick-Flow Discharge Rates and Ages, and General Water Quality of Big Spring in Carter County, Missouri, 2000-04

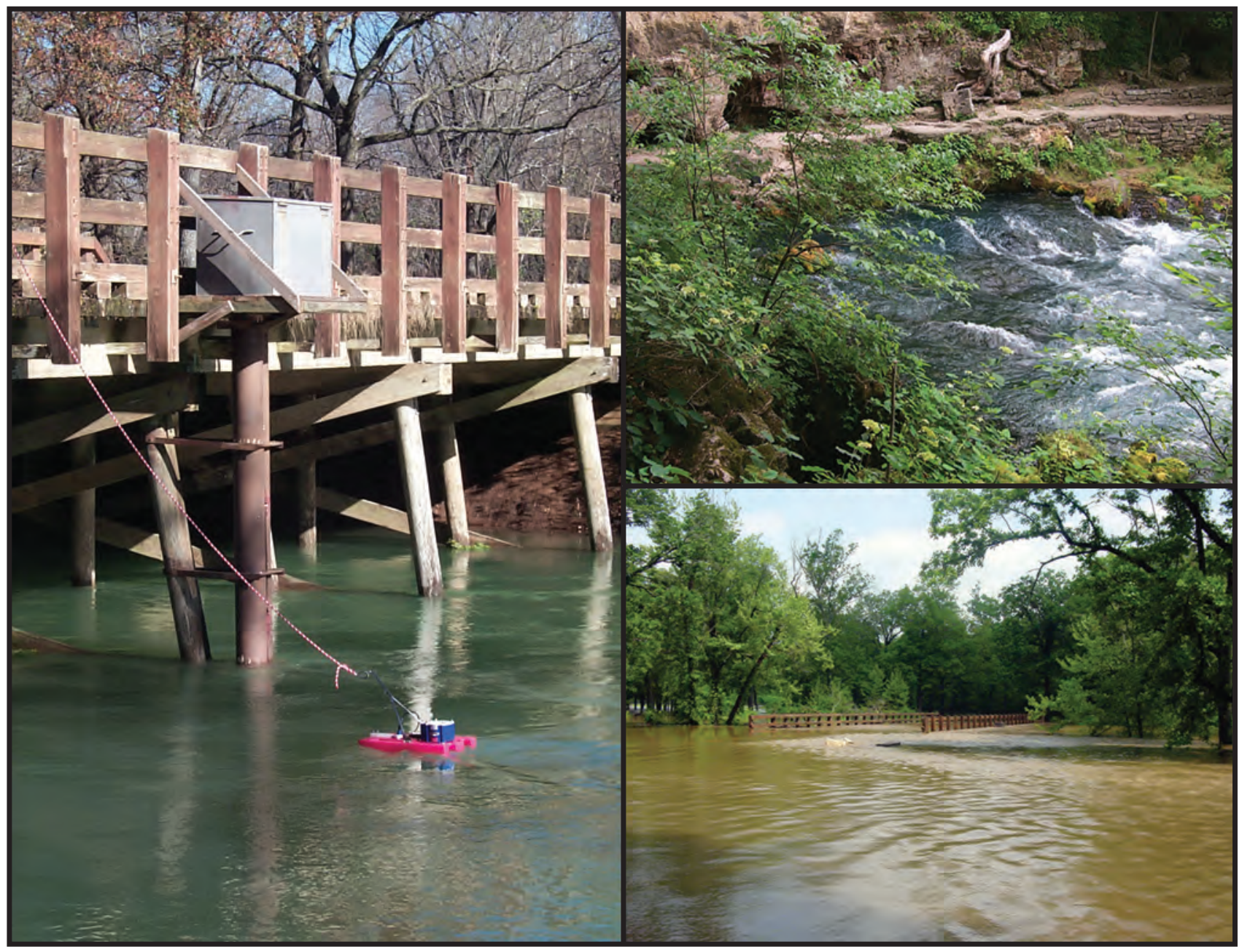

Scientific Investigations Report 2007-5049 
Cover photographs: U.S. Geological Survey gaging station on National Park Service wooden handrail bridge over Big Spring branch. A tow-behind acoustic Doppler current profiler used to make discharge measurements in the spring branch is tethered to bridge (left). Big Spring discharging from the base of dolostone bluff (upper right). Big Spring gaging station inundated by flood waters from the Current River, May 8, 2002 (lower right). Photographs by Michael J. Kleeschulte, U.S. Geological Survey. 


\section{Recharge Area, Base-Flow and Quick-Flow Discharge Rates and Ages, and General Water Quality of Big Spring in Carter County, Missouri, 2000-04}

By Jeffrey L. Imes, L. Niel Plummer, Michael J. Kleeschulte, and John G. Schumacher

Scientific Investigations Report 2007-5049 


\section{U.S. Department of the Interior DIRK KEMPTHORNE, Secretary}

\section{U.S. Geological Survey \\ Mark D. Myers, Director}

\section{U.S. Geological Survey, Reston, Virginia: 2007}

For product and ordering information:

World Wide Web: http://www.usgs.gov/pubprod

Telephone: 1-888-ASK-USGS

For more information on the USGS--the Federal source for science about the Earth, its natural and living resources, natural hazards, and the environment:

World Wide Web: http://www.usgs.gov

Telephone: 1-888-ASK-USGS

Any use of trade, product, or firm names is for descriptive purposes only and does not imply endorsement by the U.S. Government.

Although this report is in the public domain, permission must be secured from the individual copyright owners to reproduce any copyrighted materials contained within this report.

Suggested citation:

Imes, J.L., Plummer, L.N., Kleeschulte, M.J., and Schumacher, J.G., 2007, Recharge area, base-flow and quick-flow discharge rates and ages, and general water quality of Big Spring in Carter County, Missouri, 2000-04: U.S. Geological Survey Scientific Investigations Report 2007-5049, 80 p. 


\section{Contents}

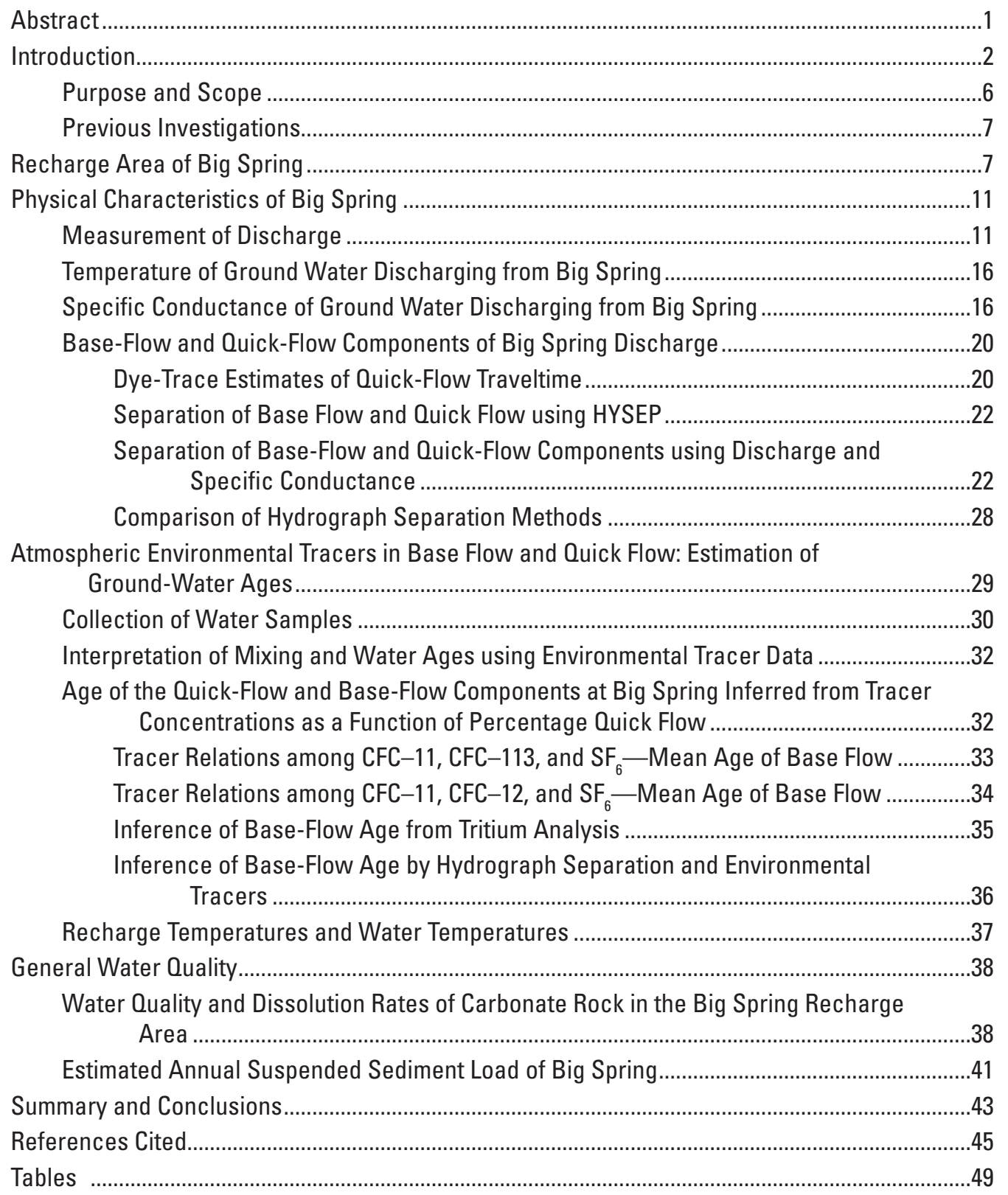




\section{Figures}

1. Photograph showing Big Spring during a low-flow period in September 2001 at a daily mean discharge of 272 cubic feet per second ....................................................

2. Topographic map of Big Spring vicinity showing selected features .................................3

3. Generalized geohydrologic section from eastern Howell County to eastern Carter County through the Big Spring and Greer Spring recharge areas.

4. Map showing results of dye-trace investigations that successfully identified a hydrologic connection between a sinkhole or losing stream reach and a

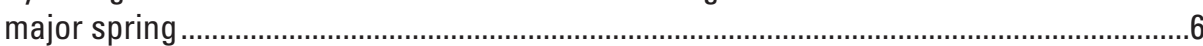

5. General Land Office coordinate system .........................................................................

6-7. Maps showing-

6. Shallow measured potentiometric surface of the Ozark aquifer, summer 2000 .......9

7. Deep potentiometric surface of the Ozark aquifer, summer 2000 . 10

8-21. Graphs showing-

8. Big Spring accumulated daily mean discharge and residual discharge and accumulated departure from normal precipitation, water years 1922 through 2004

9. Comparison of gage heights at the National Park Service staff gage and the U.S. Geological Survey gaging station.

10. Relation between water velocity and gage height in the Big Spring branch at the U.S. Geological Survey gaging station.

11. Gage height and average acoustic Doppler velocity recorded in 6-hour time increments from February 1, 2002, to January 23, 2004...

12. Big Spring mean monthly $(A)$ and daily mean water temperatures and daily mean discharge (B) for water years 2001-04 .

13. Big Spring daily mean discharge and specific conductance for water years 2001-04.

14. Emission intensity of dye in water samples collected from Big Spring as a function of time after dye injection

15. Base-flow and quick-flow components of Big Spring discharge derived using HYSEP hydrograph separation method.

16. Base-flow and quick-flow components of Big Spring discharge derived using spring discharge and specific conductance data.

17. Normalized rate of decline of quick-flow discharge for seven hydrograph events

18. Concentrations of chlorofluorocarbons (CFC-11, CFC-12, and CFC-113) and sulfur hexafluoride $\left(\mathrm{SF}_{6}\right)$ in North American air and tritium in precipitation in Missouri decayed to 2002, 1940 to 2002

19. Discharge from Big Spring as a function of percentage quick flow, water years 2001-04

20. Concentrations of chlorofluorocarbons (CFC-11, CFC-12, and CFC-113) and sulfur hexafluoride $\left(\mathrm{SF}_{6}\right)$ in discharge from Big Spring as a function of percentage quick flow.

21. Concentrations of chlorofluorocarbon (CFC-11) and sulfur hexafluoride $\left(\mathrm{SF}_{6}\right)$ in discharge from Big Spring and Greer Spring in relation to several possible mixing models. 
22-30. Graphs showing-

22. Concentrations of chlorofluorocarbon (CFC-113) and sulfur hexafluoride $\left(\mathrm{SF}_{6}\right)$ in discharge from Big Spring and Greer Spring in relation to several possible mixing models.

23. Concentrations of chlorofluorocarbons (CFC-11 and CFC-12) in discharge from Big Spring and Greer Spring in relation to several possible mixing models

24. Concentrations of chlorofluorocarbon (CFC-12) and sulfur hexafluoride $\left(\mathrm{SF}_{6}\right)$ in discharge from Big Spring and Greer Spring in relation to several possible mixing models.

25. Tritium concentrations in precipitation, decayed to 2002, with concentrations of chlorofluorocarbons (CFC-11 and CFC-113) and sulfur hexafluoride $\left(\mathrm{SF}_{6}\right)$ in discharge from Big Spring and Greer Spring

26. Calculated and median concentrations of chlorofluorocarbons (CFC-11, CFC-12, and CFC-113) in base flow as a function of percentage quick flow for Big Spring discharge.

27. Recharge temperature determined from analyses of dissolved nitrogen $\left(\mathrm{N}_{2}\right)$ and argon (Ar) gas with the field-measured water temperature, 2001-03

28. Relations between specific conductance, concentrations of selected inorganic constituents, fecal coliform densities, and discharge at Big Spring, 1973-2002

29. Relation between bicarbonate and the sum of calcium, magnesium, and strontium, 1973-2005.

30. Suspended sediment load in water discharging from Big Spring, 2001-04 ...........42

\section{Tables}

1. Ground-water levels measured in domestic and public-supply wells during the summer (April-July) 2000 and fall (October-November) 2000 and altitudes of selected perennial springs.

2. Annual departure from normal precipitation and annual mean discharge data for Big Spring, water years 1922 through 2004

3. Water temperature and specific conductance measurements at the U.S. Geological Survey gaging station and Big Spring orifice, January 2001 to May 2005

4. Summary of base-flow and quick-flow hydrograph-separation methods for Big Spring, 2001-04

5. Atmospheric concentrations of CFC-11, CFC-12, CFC-113, $\mathrm{SF}_{6^{\prime}}$ and ${ }^{3} \mathrm{H}$ in precipitation in southern Missouri, 2001-03.

6. Concentrations of dissolved gases in water samples from Big Spring and Greer Spring, 2001-03

7. Summary of average chlorofluorocarbon (CFC) concentrations, CFC apparent ages, and CFC-113/CFC-11 binary mixing model results from Big Spring and Greer Spring, 2001-03

8. Summary of sulfur hexafloride $\left(\mathrm{SF}_{6}\right)$ and tritium $\left({ }^{3} \mathrm{H}\right)$ data from Big Spring and Greer Spring, 2001-03

9. Concentrations of selected chemical constituents, calcium and magnesium ratios and loads, bicarbonate loads, and calcite saturation index for water samples collected from Big Spring under various flow conditions, 2000-02. 
10. Suspended sediment concentrations and sediment load of water discharging from Big Spring, 2001-04

\section{Conversion Factors and Datum}

\begin{tabular}{|c|c|c|}
\hline Multiply & By & To obtain \\
\hline \multicolumn{3}{|c|}{ Length } \\
\hline inch (in.) & 2.54 & centimeter $(\mathrm{cm})$ \\
\hline foot $(\mathrm{ft})$ & 0.3048 & meter (m) \\
\hline mile (mi) & 1.609 & kilometer $(\mathrm{km})$ \\
\hline \multicolumn{3}{|c|}{ Area } \\
\hline square mile $\left(\mathrm{mi}^{2}\right)$ & 259.0 & hectare (ha) \\
\hline \multicolumn{3}{|c|}{ Volume } \\
\hline gallon (gal) & 3.785 & liter (L) \\
\hline million gallons (Mgal) & 3,785 & cubic meter $\left(\mathrm{m}^{3}\right)$ \\
\hline cubic foot $\left(\mathrm{ft}^{3}\right)$ & 0.02832 & cubic meter $\left(\mathrm{m}^{3}\right)$ \\
\hline \multicolumn{3}{|c|}{ Flow rate } \\
\hline foot per second (ft/s) & 0.3048 & meter per second $(\mathrm{m} / \mathrm{s})$ \\
\hline cubic foot per second $\left(\mathrm{ft}^{3} / \mathrm{s}\right)$ & 0.02832 & cubic meter per second $\left(\mathrm{m}^{3} / \mathrm{s}\right)$ \\
\hline gallon per minute (gal/min) & 0.06309 & liter per second (L/s) \\
\hline gallon per day (gal/d) & 0.003785 & cubic meter per day $\left(\mathrm{m}^{3} / \mathrm{d}\right)$ \\
\hline million gallons per day $(\mathrm{Mgal} / \mathrm{d})$ & 0.04381 & cubic meter per second $\left(\mathrm{m}^{3} / \mathrm{s}\right)$ \\
\hline inch per year (in/yr) & 25.4 & millimeter per year $(\mathrm{mm} / \mathrm{yr})$ \\
\hline mile per day $(\mathrm{mi} / \mathrm{d})$ & 1.609 & kilometer per day $(\mathrm{km} / \mathrm{d})$ \\
\hline \multicolumn{3}{|c|}{ Mass } \\
\hline pound, avoirdupois (lb) & 0.4536 & kilogram (kg) \\
\hline pound, avoirdupois (lb) & $0.4536 \times 10^{14}$ & picogram (pg) \\
\hline ton, short $(2,000 \mathrm{lb})$ & 0.9072 & megagram $(\mathrm{Mg})$ \\
\hline ton per day (ton/d) & 0.9072 & metric ton per day \\
\hline \multicolumn{3}{|c|}{ Hydraulic conductivity } \\
\hline foot per day (ft/d) & 0.3048 & meter per day $(\mathrm{m} / \mathrm{d})$ \\
\hline
\end{tabular}

Temperature in degrees Celsius $\left({ }^{\circ} \mathrm{C}\right)$ may be converted to degrees Fahrenheit $\left({ }^{\circ} \mathrm{F}\right)$ as follows:

$$
{ }^{\circ} \mathrm{F}=\left(1.8 x^{\circ} \mathrm{C}\right)+32
$$

Vertical coordinate information is referenced to the "National Geodetic Vertical Datum of 1929 (NGVD 29)."

Horizontal coordinate information is referenced to the "North American Datum of 1927 (NAD 27)."

Altitude, as used in this report, refers to distance above the vertical datum.

Specific conductance is given in microsiemens per centimeter at 25 degrees Celsius $(\mu \mathrm{S} / \mathrm{cm}$ at $\left.25^{\circ} \mathrm{C}\right)$.

Concentrations of chemical constituents in water are given either in milligrams per liter (mg/L) or micrograms per liter $(\mu \mathrm{g} / \mathrm{L})$.

Water year in U.S. Geological Survey reports dealing with surface-water supply is the 12month period 0 ctober 1 through September 30 . The water year is designated by the calendar year in which it ends and which includes 9 of the 12 months. Thus, the year ending September 30,2007 , is called the "2007 water year." 


\title{
Recharge Area, Base-Flow and Quick-Flow Discharge Rates and Ages, and General Water Quality of Big Spring in Carter County, Missouri, 2000-04
}

\author{
Jeffrey L. Imes, L. Niel Plummer, Michael J. Kleeschulte, and John G. Schumacher
}

\section{Abstract}

Exploration for lead deposits has occurred in a mature karst area of southeast Missouri that is highly valued for its scenic beauty and recreational opportunities. The area contains the two largest springs in Missouri (Big Spring and Greer Spring), both of which flow into federally designated scenic rivers. Concerns about potential mining effects on the area ground water and aquatic biota prompted an investigation of Big Spring.

Water-level measurements made during 2000 helped define the recharge area of Big Spring, Greer Spring, Mammoth Spring, and Boze Mill Spring. The data infer two distinct potentiometric surfaces. The shallow potentiometric surface, where the depth-to-water is less than about 250 feet, tends to mimic topographic features and is strongly controlled by streams. The deep potentiometric surface, where the depth-towater is greater than about 250 feet represents ground-water hydraulic heads within the more mature karst areas. A highly permeable zone extends about 20 mile west of Big Spring toward the upper Hurricane Creek Basin. Deeper flowing water in the Big Spring recharge area is directed toward this permeable zone. The estimated sizes of the spring recharge areas are 426 square miles for Big Spring, 352 square miles for Greer Spring, 290 square miles for Mammoth Spring, and 54 square miles for Boze Mill Spring.

A discharge accumulation curve using Big Spring daily mean discharge data shows no substantial change in the discharge pattern of Big Spring during the period of record (water years 1922 through 2004). The extended periods when the spring flow deviated from the trend line can be attributed to prolonged departures from normal precipitation. The maximum possible instantaneous flow from Big Spring has not been adequately defined because of backwater effects from the Current River during high-flow conditions. Physical constraints within the spring conduit system may restrict its maximum flow. The largest discharge measured at Big Spring during the period of record (water years 1922 through 2004) was 1,170 cubic feet per second on December 7, 1982.
The daily mean water temperature of Big Spring was monitored during water years 2001 through 2004 and showed little variability, ranging from 13 to $15^{\circ} \mathrm{C}$ (degree Celsius). Water temperatures generally vary less than $1{ }^{\circ} \mathrm{C}$ throughout the year. The warmest temperatures occur during October and November and decrease until April, indicating Big Spring water temperature does show a slight seasonal variation.

The use of the traditional hydrograph separation program HYSEP to determine the base flow and quick flow or runoff components at Big Spring failed to yield base-flow and quick-flow discharge curves that matched observations of spring characteristics. Big Spring discharge data were used in combination with specific conductance data to develop an improved hydrograph separation method for the spring. The estimated annual mean quick flow ranged from 15 to 48 cubic feet per second for the HYSEP analysis and ranged from 26 to 154 cubic feet per second for the discharge and specific conductance method for water years 2001 to 2004.

Using the discharge and specific conductance method, the estimated base-flow component rises abruptly as the spring hydrograph rises, attains a peak value on the same day as the discharge peak, and then declines abruptly from its peak value. Several days later, base flow begins to increase again at an approximately linear trend, coinciding with the time at which the percentage of quick flow has reached a maximum after each recharge-induced discharge peak. The interval between the discharge peak and the peak in percentage quick flow ranges from 8 to 11 days for seven hydrograph peaks, consistent with quick-flow traveltime estimates by dye-trace tests from the mature karst Hurricane Creek Basin in the central part of the recharge area.

Concentrations of environmental tracers chlorofluorocarbons (CFCs: CFC-11, CFC-12, CFC-113), and sulfur hexafluoride in discharge from Big Spring vary approximately linearly with percent quick flow from about 5 to 45 percent of discharge. Linear extrapolation to 100 percent quick flow implies $\mathrm{CFC}$ and $\mathrm{SF}_{6}$ concentrations nearly identical to those in the 2002 atmosphere and indicates a modern age for the quick-flow component. Tracer concentrations for less than 
about 5 percent quick flow are increasingly lower than those expected from linear extrapolation to zero percent quick flow, indicating that the reservoir of older water in the Big Spring watershed may be a series of water mixtures with piston-flow ages greater than those obtained by extrapolation to zero percent quick flow. Each sample point with a low percentage of quick flow (less than 5 percent) may be a unique mixture.

Environmental tracer data from Big Spring plot intermediate to the simple binary mixing of modern and old, pretracer water and results from the exponential mixture model. The mean ages of waters in the base-flow component approximately range from 30 to 200 years. The mean age of the base-flow component is youngest ( 30 to 40 years) in samples containing the highest quick-flow component (45 percent quick flow) and increases to 200 years or more as the fraction of quick flow decreases to less than 5 percent. Tritium data are consistent with a model of dilution of a modern component with an old, pre-tracer component and indicates that the old fraction is mostly pre-1960s in age with mean residence time of more than several hundred years. All of the samples from Big Spring and Greer Spring have water temperatures warmer than their nitrogen-argon recharge temperature, which range from approximately 10.5 to $14{ }^{\circ} \mathrm{C}$, suggesting recharge to the Big Spring watershed occurs primarily in late winter to early spring. The water temperatures at Big Spring are consistent with relatively shallow circulation (less than about 600 feet), and the water does not appear to be warmed by deep circulation along a geothermal gradient.

Specific conductance values and concentrations of most inorganic constituents in water samples from Big Spring generally decrease with increasing discharge because of dilution with quick-flow water of lower ionic strength. Concentrations of some constituents such as chloride and nitrite plus nitrate, and fecal coliform densities, however, did not decrease with increasing discharge, indicating that quick flow probably is a more important source of these constituents compared to base flow. Water samples from Big Spring plot along the line of dolomite dissolution by carbonic acid, are at equilibrium with dolomite and calcite, and have a molar ratio of $\mathrm{Ca}: \mathrm{Mg}$ of near 1, indicating dissolution of the mineral dolomite as the primary control on concentrations of calcium, magnesium, and bicarbonate. The flux of calcium and magnesium from Big Spring represents the dissolution of about 1,950 cubic feet of dolomite per day. The suspended sediment load of Big Spring was estimated to range from about 1 to about 70 tons per day, and the sediment load during base-flow periods ranged from about 1 to about 7 tons per day.

\section{Introduction}

Big Spring (fig. 1) in Carter County, Missouri, emerges from an exposed hydraulic conduit at the base of a dolostone bluff along the western edge of the Current River floodplain (fig. 2). The spring water forms a pool about $200 \mathrm{ft}$ (feet)

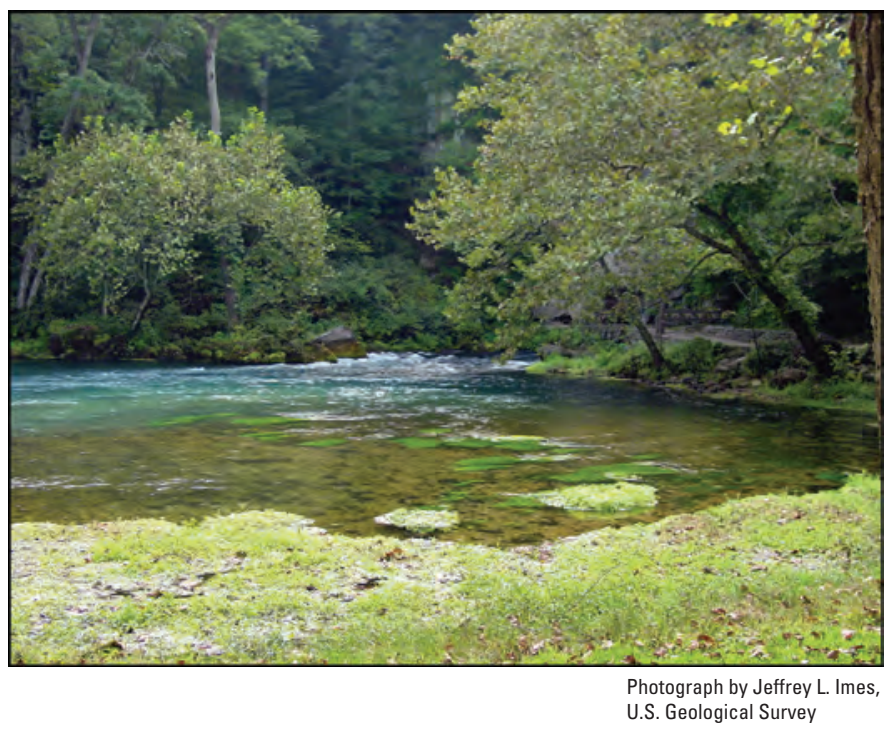

Figure 1. Big Spring during a low-flow period in September 2001 at a daily mean discharge of 272 cubic feet per second.

in diameter before flowing southeasterly $2,000 \mathrm{ft}$ along the spring branch to the main channel of the Current River. The alluvial valley and adjacent uplands near the spring are part of the Ozark National Scenic Riverways (ONSR), administered by the National Park Service (NPS). Visitors drive over the NPS small wooden-handrail bridge that spans the spring branch, park across from the spring pool, and walk along a well-maintained path to the spring orifice. The mean annual discharge of Big Spring is $445 \mathrm{ft}^{3} / \mathrm{s}$ [(cubic feet per second); 288 million gallons per day; (Hauck and Harris, 2006)], sufficient discharge to create an impressive aural and visual display of power as the ground water is forcefully ejected from the bedrock. Vineyard and Feder (1982) give an overview of Big Spring and its related karst features.

Water is transmitted to Big Spring through rocks that form part of the Ozark aquifer (Imes, 1990a), the most productive aquifer in the Ozark Plateaus aquifer system (Imes and Emmett, 1994) of southern Missouri. The Ozark Plateaus aquifer system rests on granite and rhyolite rocks of Precambrian age that form the Basement confining unit (fig. 3). The Basement confining unit nearly is impermeable except where faults and fractures are present or where it crops out and has been extensively weathered. Well yields in these more permeable areas commonly are less than 10 gallons per minute. Isolated knobs are common on the eroded Precambrian surface and may extend hundreds of feet into the overlying bedrock. The St. Francois aquifer (Imes, 1990b) overlies the Basement confining unit and consists of the Lamotte Sandstone and the Bonneterre Formation. Where the St. Francois aquifer is near land surface, the aquifer yields adequate supplies of water for domestic and small-capacity public-supply wells. The St. Francois confining unit (Imes, 1990c) overlies the St. Francois aquifer and is formed by the Davis Formation and the DerbyDoerun Dolomite. The St. Francois confining unit is composed 


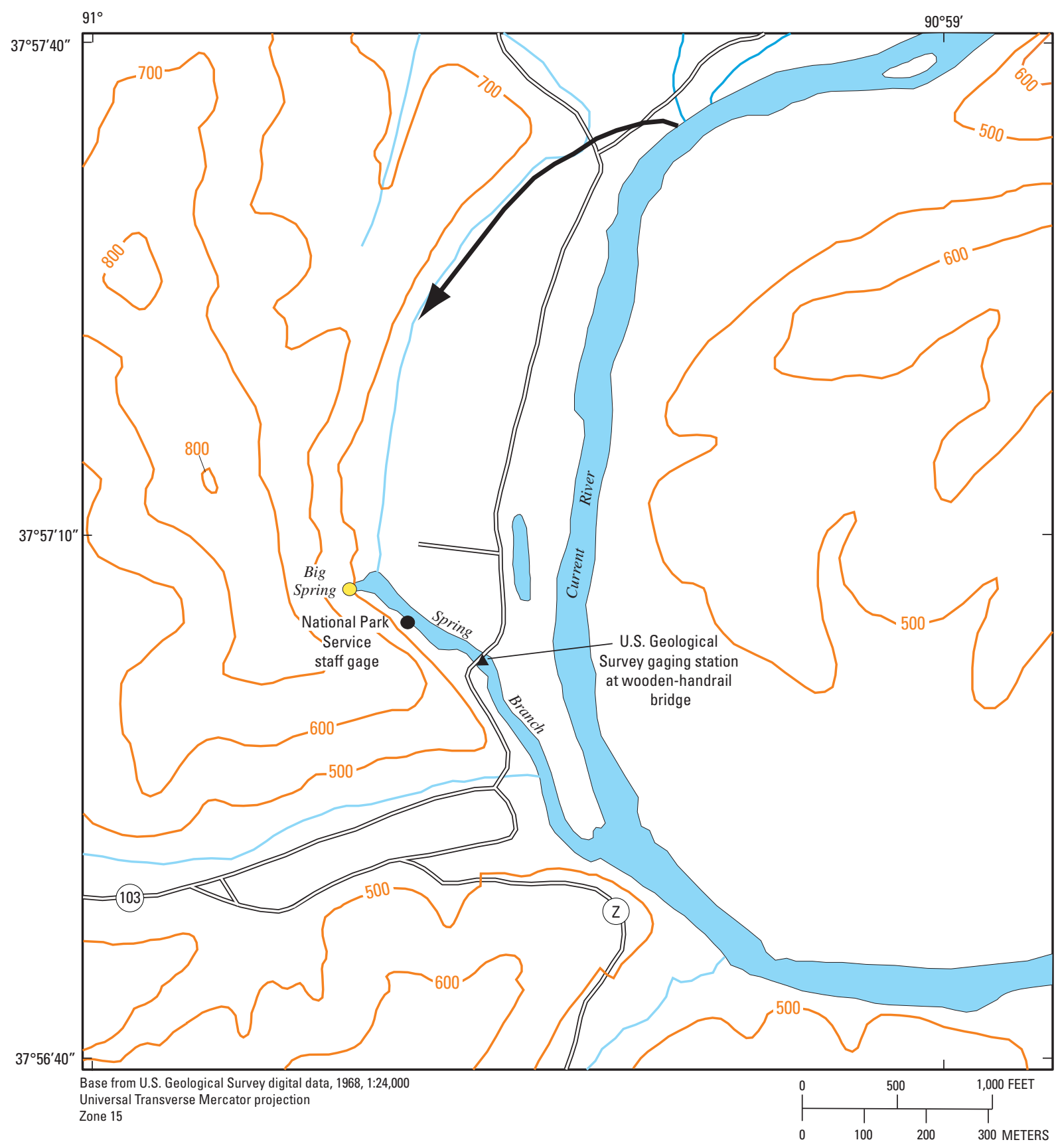

EXPLANATION

— 600 — Topographic contour — Shows altitude of land surface. Contour interval is 100 feet. Datum is North American Vertical Datum of 1927

Flow path-Flow path of flood waters from the Current River

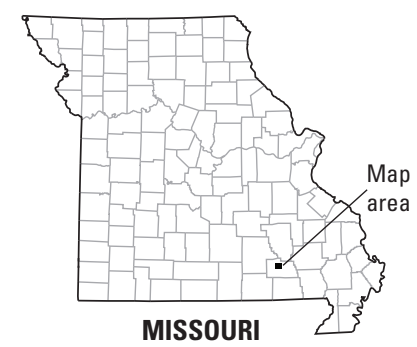

Figure 2. Topographic map of Big Spring vicinity showing selected features. 


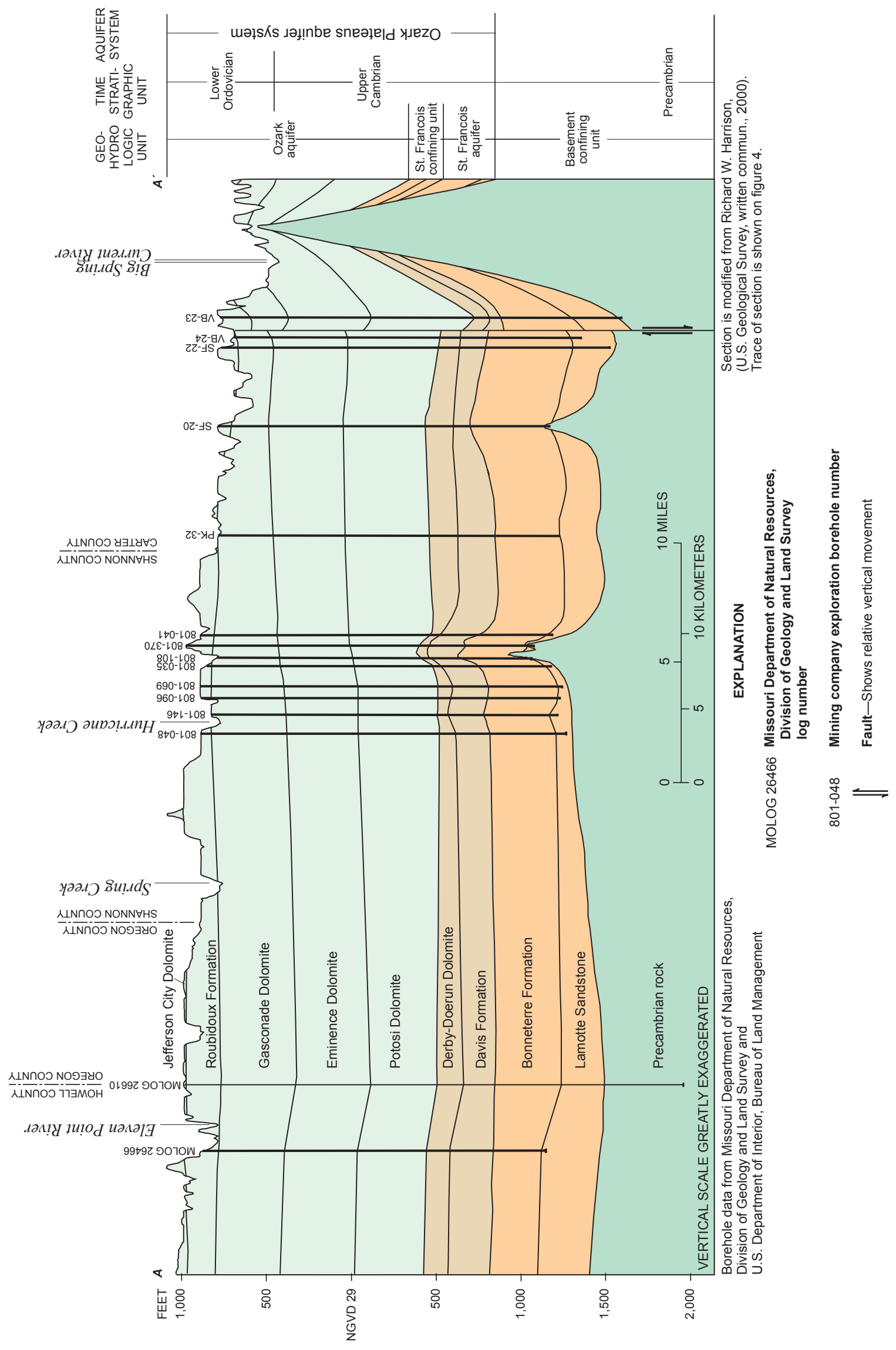


of dense, fine-grained carbonate rock and shale with little primary permeability, and is an effective barrier to ground-water flow between the St. Francois aquifer and Ozark aquifer. Near Big Spring, the overlying and uppermost Ozark aquifer consists of the Potosi Dolomite, Eminence Dolomite, Gasconade Dolomite, Roubidoux Formation, and Jefferson City Dolomite. The predominantly dolostone aquifer contains some thick sandstone units and is the most productive and widely used aquifer in southern Missouri. The Ozark aquifer supplies water to numerous springs in southern Missouri, including several springs that are among the largest in the United States.

Historic dye-trace investigations (fig. 4) in the region show that water flowing to Big Spring originates as precipitation that falls on the Ozark aquifer in drainage basins west of the spring. The general extent of the Big Spring recharge area is known from potentiometric mapping and dye-trace investigations, but the precise boundaries of the recharge area are not well defined in some areas. The difficulty in defining the recharge area is caused by the mature karst terrain that created the spring. Spring recharge areas cannot simply be delineated from the topographic surface-water divides that contain the spring.

In karst areas, subsurface interbasin transfer of water from one surface-water drainage basin to another is common. In the absence of karst, precipitation that falls in a particular watershed becomes recharge to the ground-water flow system and normally would flow through permeable bedrock or alluvium and discharge to streams within the same basin. The presence of a mature karst terrain can increase the quantity of precipitation that recharges the ground-water flow system and also can increase the flow rate of ground water through the bedrock. If the extent of the karst is sufficiently large to cross surface-water divides, an interbasin transfer of ground water can occur. Consequently, precipitation falling in one surfacewater basin can be discharged in a neighboring basin.

The karst terrain present throughout the Big Spring recharge area was formed principally by the dissolution of the carbonate bedrock and is characterized by sinkholes, vertical joints, losing streams, caves, and springs linked by a complex underground drainage system of fractures and conduits. Sinkholes are formed when bedrock is dissolved by slightly acidic ground water and bridged rock and soil overburden collapse into the resulting void. Losing streams occur where areas of high streambed hydraulic conductivity exists in combination with ground-water levels below the streambed elevation. This causes a substantial part of the stream to flow through the streambed into the bedrock. For more information, a report by Orndorff and others (2006) gives a detailed description of how the Ozark karst system may have developed.

Most of the land in the recharge area west of Big Spring is part of the Mark Twain National Forest (fig. 4). The surface rights to the forest are administered for the public by the U.S. Department of Agriculture, Forest Service (FS), and the subsurface rights are administered by the U.S. Bureau of Land Management (BLM). Smaller areas of private land holdings are scattered throughout the forest.
Southeastern Missouri has been a prominent lead-mining area since shortly after the first French explorations occurred in the area in about 1700 . During the 1700 s, lead mining was conducted on a small scale and the first mines were mostly surface diggings performed with pick and shovel by manual labor. Additional mines were opened during the $1800 \mathrm{~s}$, especially after the Civil War fueled an increased need for lead. By 1900, a network of surface and shallow subsurface mines (several hundred feet below the ground surface) were in operation throughout the area now known as the Old Lead Belt (fig. 4). By the 1940s, lead reserves in the Old Lead Belt were seriously depleted and the exploration for new lead reserves moved west. Lead ore was discovered near Eminence in the late 1950s, and in the Viburnum Trend in the 1960s. The shallower (500 to 1,500 ft deep) Viburnum Trend discoveries were developed first and eventually 10 mines were opened (Burford, 1978; Warner and others, 1974).

In anticipation of future declining reserves of lead ore in the Viburnum Trend, mining companies continued to explore the area south of Winona and north of the Eleven Point River (fig. 4). More than 300 exploration boreholes have been drilled in this exploration area since the 1980s. Much of the exploration has occurred in the Mark Twain National Forest under prospecting permits issued by the FS and BLM. The exploration area is within a region, highly valued for its scenic beauty and recreational opportunities, which more than 2 million people visit annually. The focus of this exploration has been ancient reef structures associated with buried Precambrian knobs beneath the Spring Creek and Hurricane Creek basins (Kleeschulte and Seeger, 2000). Hurricane Creek is a major losing stream located within the recharge area of Big Spring.

Greer Spring, the second largest spring in Missouri, with an annual mean discharge of $342 \mathrm{ft}^{3} / \mathrm{s}$ [(221 million gallons per day; (Hauck and Harris, 2006)] is located at the southern edge of the exploration area within the Eleven Point National Wild and Scenic River (EPNWSR), which is administered by the FS (fig. 4). Based on dye-trace studies and water-level maps [unpublished data on file at the USGS (U.S. Geological Survey) office, Rolla, Missouri], the primary recharge area of Greer Spring may be about 25 mi northwest of the spring at the western edge of the exploration area.

Several smaller springs are present along three streams (Eleven Point River, Spring Creek, and Hurricane Creek; fig. 4) that flow through or near the exploration area. There are concerns that mine dewatering in this area could lower water levels and cause a decrease in ground-water discharge to the springs. The presence of losing streams in the exploration area is of concern because contaminants released during mining activities or from stored mine waste (tailings piles) potentially could migrate into the ground-water flow system, degrade the quality of water at the nearby springs, and threaten aquatic biota. The investigation of Big Spring is part of a larger investigation of the geology, hydrology, and aquatic biology of the exploration area and Viburnum Trend initiated in response to these environmental concerns (Imes, 2002). 


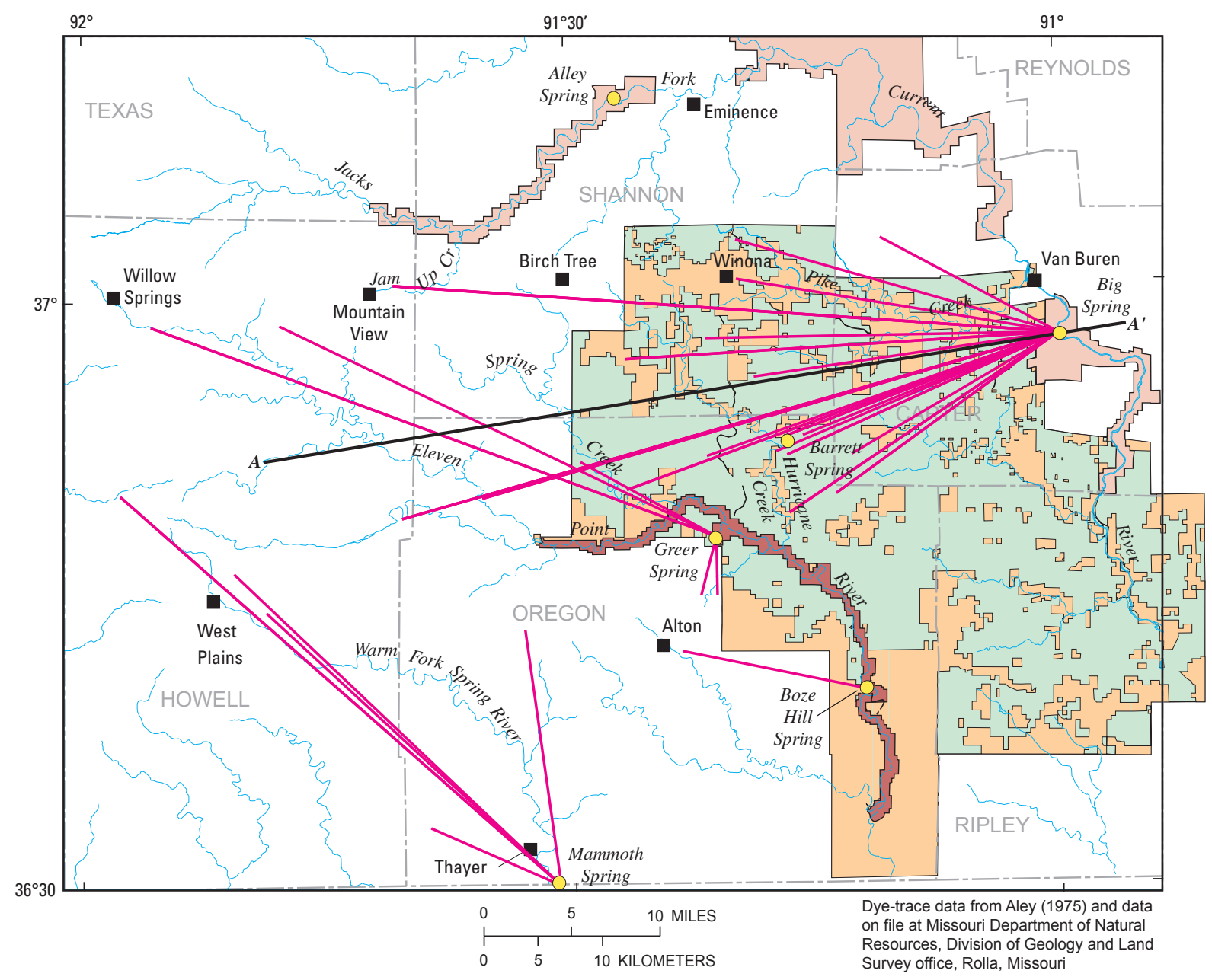

EXPLANATION

Ozark National Scenic Riverways

Eleven Point National Wild and Scenic River

Mark Twain National Forest

Private land ownership

- Dye trace

$A-A^{\prime}$ Generalized trace of section

(section shown in fig. 3)

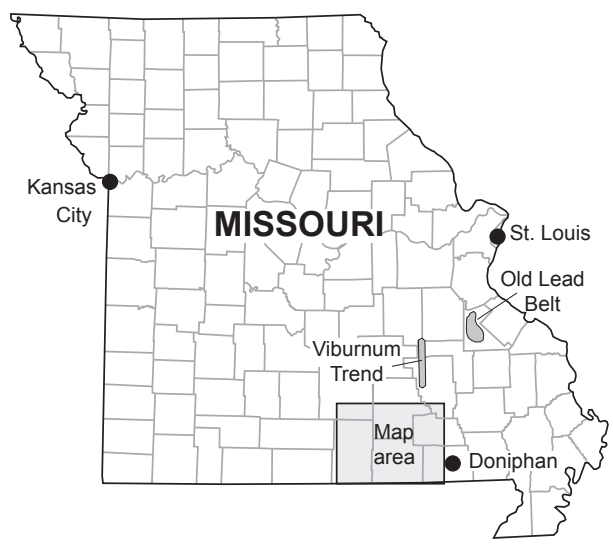

Figure 4. Results of dye-trace investigations that successfully identified a hydrologic connection between a sinkhole or losing stream reach and a major spring.

\section{Purpose and Scope}

This report characterizes different aspects pertaining to the general hydrology of Big Spring and includes a delineation of the possible recharge area for Big Spring, a description of the physical characteristics of the spring and results of hydrograph separation methods used to determine the base-flow and quick-flow components of Big Spring discharge, age dating of the Big Spring base-flow and quick-flow components from isotope data, and the determination of the water-quality, 
carbonate-aquifer dissolution rates, and suspended sediment loads. The data collection for this report included the recharge area for Big Spring with the most intense data collection effort occurring at the spring and along the spring branch (fig. 2). The possible recharge areas for adjacent large springs in the region also were defined as a result of data collected during this study. Whereas Big Spring discharge data used in this report span almost the entire period of record (1922 to 2004), most of the analyses were done using hydrologic information collected during water years 2000 to 2004. Water year in U.S. Geological Survey reports is the 12-month period October 1 through September 30. The water year is designated by the calendar year in which it ends and which includes 9 of the 12 months.

\section{Previous Investigations}

The unique mature karst geology of the region has initiated many geohydrologic studies over the decades by many land management agencies, academia, and scientists. Some of these studies were general and were intended to give a broad overview of the geohydrology of the area or document existing conditions. Other studies were conducted for more specific purposes. The following discussion provides a basic understanding of the hydrologic information previously collected from the region.

Many dye-tracing investigations have been conducted in the region to determine ground-water flow directions and time of travel. Some of the earliest dye traces were reported by Aley (1975; data on file at the Missouri Department of Natural Resources, Division of Geology and Land Survey) as part of a predictive hydrologic model that was developed for the area. These dye traces generally were conducted using fluorescein dye; however, occasionally stained Lycopodium spores were used. All results were determined by visual detection. Thirtyfour dye traces were tabulated (Aley, 1975), showing injection and recovery locations, time of travel, straight line distances, and altitude of injection to recovery sites. The results of these dye traces helped to better define the recharge area of both Big Spring and Greer Spring. A dye-trace investigation conducted by the USGS using rhodamine-WT dye and a scanning spectrofluorophotometer as the dye-detection device was performed as a part of another study, and verified a previous trace performed by Aley (Imes and Fredrick, 2002).

The USGS determined ground-water altitudes and seasonal ground-water fluctuations in the study area by measuring the depth-to-water in 57 wells during the spring and fall from 1990 through 1993. The water-level data were used in conjunction with the previously available dye-trace data to determine ground-water flow directions in the area between the exploration area and Big Spring and to further identify areas of mature karst development where water is rapidly transported to Big Spring (Imes and Kleeschulte, 1995). Continuous water-level recorders also were installed on three deep wells during the study to assess the seasonal response of water levels in the wells.
A seepage run (a series of stream discharge measurements made in a short period of time) was conducted in 1995 during a base-flow period (minimum streamflow and minimum daily fluctuations) in the Eleven Point River, Spring Creek, and Hurricane Creek (Kleeschulte, 2000). Losing stream reaches and areas of ground-water discharge to streams were identified. No losing reaches were identified in the mainstem of the Eleven Point River, but the upstream reaches of Spring Creek and Hurricane Creek contain losing stream reaches. Dye-trace information confirms water lost by Hurricane Creek flows eastward through the ground-water flow system, beneath a surface-water basin divide and eventually discharges at Big Spring.

In a series of reports (Kleeschulte and Seeger, 2000; 2001; and 2003), the confining ability of the St. Francois confining unit was assessed in three separate areas (exploration area, region between Big Spring and the exploration area, and Viburnum Trend). Based on the calculated vertical hydraulic conductivity ranges, the St. Francois confining unit is considered "tight" in all three areas as compared to the ranges in the adjacent aquifers. However, in relation to each other, the confining unit in the exploration area has the smallest vertical hydraulic conductivity and the unit in the Viburnum Trend is the most conductive. Other studies (Warner and others, 1974; and Kleeschulte, 2001) have concluded no apparent large cones of depression have developed in the potentiometric surface of the Ozark aquifer as a result of mining activity in the Viburnum Trend. Therefore, using similar mining practices as those along the Viburnum Trend, no large cones of depression in the Ozark aquifer would be expected in the exploration area, unless preferred-path secondary permeability has developed along faults or fractures or resulted from exploration activities (Kleeschulte and Seeger, 2003).

\section{Recharge Area of Big Spring}

Two extensive synoptic water-level measurements were made in and around the estimated recharge areas of Big Spring and Greer Spring (as inferred from previous dye-tracing investigations and limited potentiometric mapping) to better define the recharge areas of these springs. The area in which water levels were measured also was large enough to include Boze Mill Spring and part of the Mammoth Spring (fig. 4) recharge area. Water levels were measured or observed in 346 wells and 7 springs during the summer and fall of 2000 (table 1, at the back of this report). The altitudes of water levels in these wells and the altitude of several springs reported in table 1 were used in the construction of potentiometric maps. The 24.5 inches of measured rainfall in 2000 at Alley Spring [fig. 4, about $10 \mathrm{mi}$ (miles) north of the Big Spring recharge area] was 17.5 inches less than the normal annual rainfall of 42 inches per year, and reflected the drought conditions that began in late summer 1999 (University of Missouri-Columbia, 2006) and generally dry conditions experienced to fall 2001. 
Ground-water levels generally were low because of these dry conditions and even lower in areas drained by karst features in the mature karst terrain.

The locations of measured wells and springs (table 1) are shown by latitude and longitude coordinates and by the local site number, which follows the General Land Office coordinate system (fig. 5). According to this system, the first three sets of numbers representing a site location designate township, range, and section. The letters that follow indicate quarter section, quarter-quarter section, and quarter-quarter-quarter section. The quarter sections are represented by letters A, B, $\mathrm{C}$, and $\mathrm{D}$ in counterclockwise order, starting in the northeastern quadrant. Land-surface altitude at the wells and springs were determined by interpolating contour data on 7.5-minute topographic maps and are considered accurate to one-half the contour interval, which is generally plus or minus $10 \mathrm{ft}$. Well construction information usually is difficult to obtain for the older domestic wells encountered during the well survey. Total well depth is known for 210 of the wells with measured water levels, and casing depth is known for 74 of the wells.

The total well depth and the open interval of the well bore can be used to determine if the water level in the well is a good approximation of the water table or is more representative of the potentiometric surface of a deeper part of the aquifer. During this study, the depth to ground water in the measured wells ranged from 0 to more than $400 \mathrm{ft}$. In areas with little or no karst development, the depth to water commonly ranges from only a few feet in perennial stream valleys to as much as $150 \mathrm{ft}$ in upland areas. The depth to ground

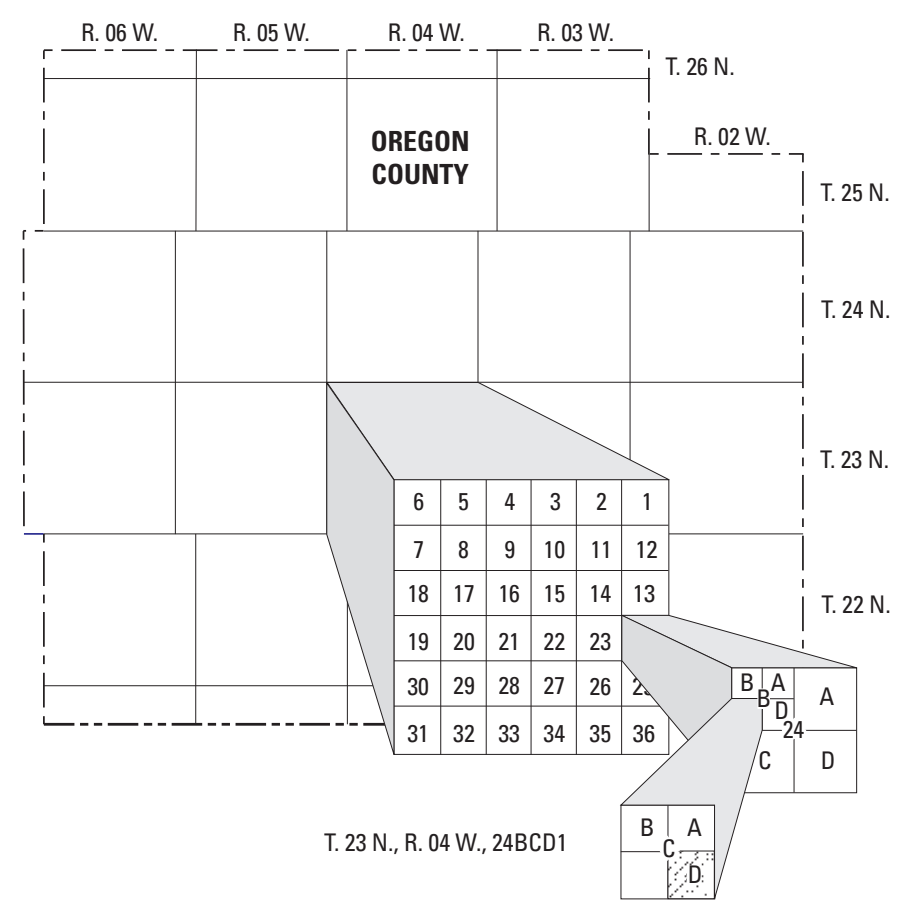

Figure 5. General Land Office coordinate system. water in areas underlain by karst can exceed $150 \mathrm{ft}$, with the greater depths to water occurring in upland areas and areas of more mature karst development. Zero depth-to-water values in table 1 indicate data from springs. The land-surface altitude of springs is assumed to represent the approximate altitude of the water table.

The measured depth-to-water during the summer of 2000 ranged from 2.1 to $448.4 \mathrm{ft}$, but exceeded $200 \mathrm{ft}$ in most wells in the headwater areas of the Eleven Point River, Spring Creek, Hurricane Creek, and Pike Creek (table 1; fig. 4). These upland areas have land-surface altitudes ranging from about 900 to $1,200 \mathrm{ft}$ and are areas of mature karst that supply water to Big Spring (altitude $413 \mathrm{ft}$ ) and Greer Spring (altitude $565 \mathrm{ft}$ ). Depth-to-water ranged from 200 to $300 \mathrm{ft}$ in several wells along the Warm Fork Spring River near West Plains and in a small area west of the Eleven Point River near Boze Mill Spring. Land-surface altitudes range from about 750 to about 1,100 ft in the Warm Fork Spring River area, which supplies water to Mammoth Spring (altitude $506 \mathrm{ft}$ ). Land-surface altitudes range from about 750 to about 950 $\mathrm{ft}$ in the upland recharge area of Boze Mill Spring (altitude $438 \mathrm{ft}$ ). Ground-water flow directions and the approximate extent of the recharge area for four large springs (Big Spring, Greer Spring, Mammoth Spring, and Boze Mill Spring) were determined using historic dye-trace data, measured depth to water, and mapped water-level altitudes (fig. 6). The estimated sizes of the spring recharge areas are $426 \mathrm{mi}^{2}$ (square miles) for Big Spring, $352 \mathrm{mi}^{2}$ for Greer Spring, $290 \mathrm{mi}^{2}$ for Mammoth Spring, and $54 \mathrm{mi}^{2}$ for Boze Mill Spring. The designated recharge areas are only meant to be suggestive of the actual spring recharge areas, which can only be more precisely determined by more detailed mapping of vertical and horizontal changes in ground-water levels and additional dye-trace investigations.

Depth-to-water measurements indicate that at least two distinct potentiometric surfaces are represented by the data set. However, several factors make it difficult to determine which potentiometric surface a particular water-level measurement represents. Most wells are open to several hundred feet of the aquifer, and well completion depths and well casing depths are not known for many of the wells. The Ozark aquifer is not homogeneous, and different geologic formations or parts of formations that comprise the aquifer can have considerably different hydraulic conductivity. The vertical and lateral extent of karst in the aquifer and the maturity of the karst are not known in detail, but can have considerable effect on potentiometric head and ground-water flow. Despite these complexities, two distinct potentiometric surfaces can be inferred from the water-level data. A shallow potentiometric surface representing water table or near water-table conditions can be mapped using water levels where the depth-to-water is less than about $250 \mathrm{ft}$ (fig. 6). A deeper potentiometric surface representing ground-water hydraulic heads within the more mature karst areas can be mapped using water levels where the depth-to-water is greater than about $250 \mathrm{ft}$ (fig. 7). 


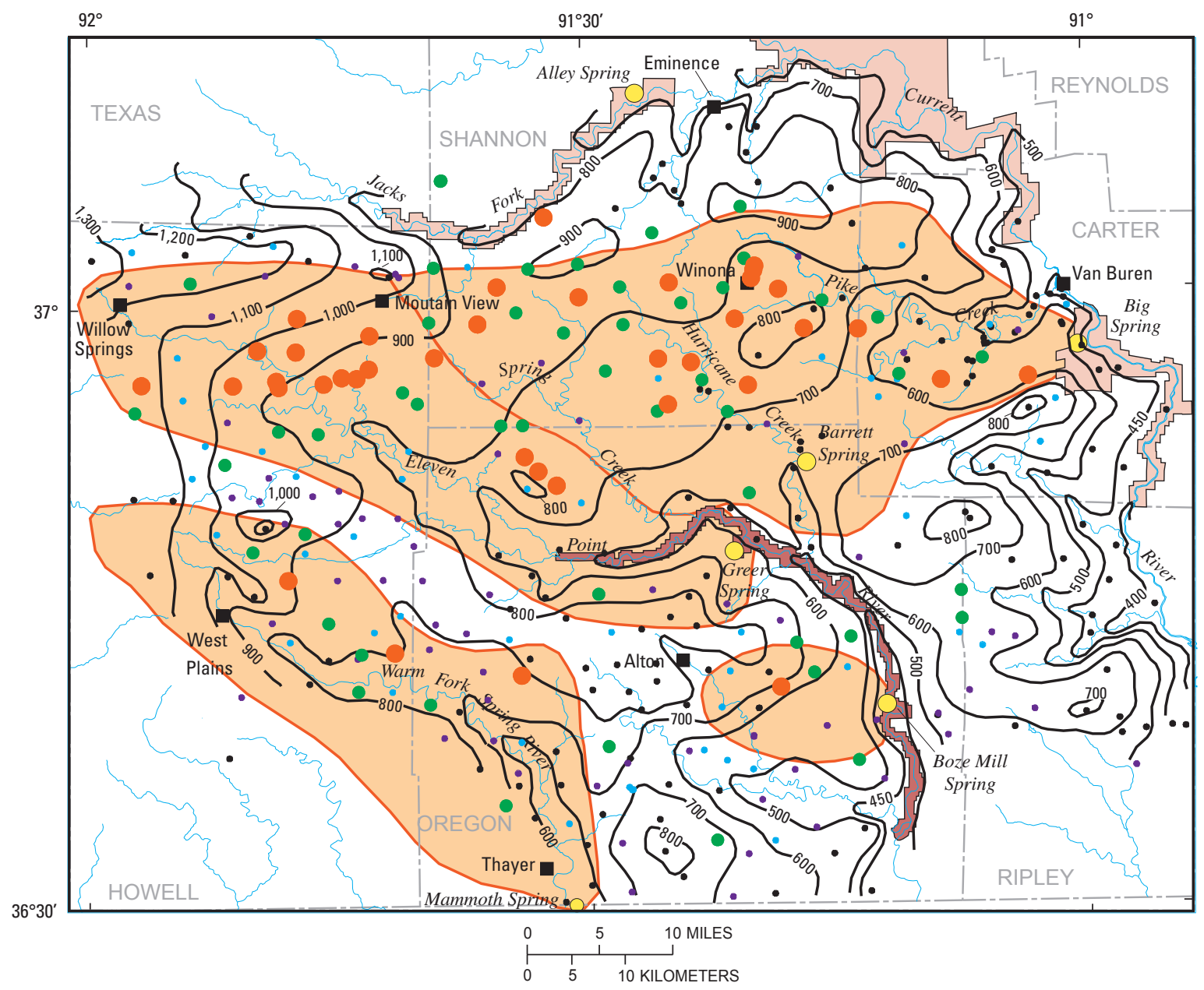

EXPLANATION

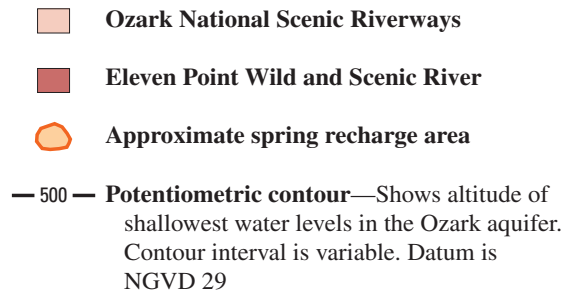

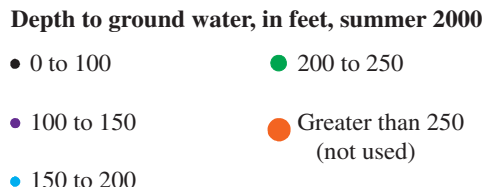

- 150 to 200 (not used)

Figure 6. Shallow measured potentiometric surface of the Ozark aquifer, summer 2000.

The shallow potentiometric surface (fig. 6) is distinctly different in the less well-developed karst areas and along the major rivers as compared to the potentiometric surface in the more mature karst areas within the delineated recharge areas. Water levels tend to mimic topographic features and are strongly controlled by streams along the Jacks Fork and Current River in the northern part of the map area, throughout most of the Current River Basin downstream from Big Spring, in the lower Eleven Point River Basin from about 30 mi upstream from Greer Spring; and in the lower Warm Fork Spring River Basin. In the recharge areas of Big Spring and
Greer Spring where mature karst features are present, water levels in many places do not mimic topographic features and generally are not controlled by the smaller streams. Spring Creek, Hurricane Creek, and Pike Creek are losing streams except near their mouths. Shallow ground-water flow in the central and eastern parts of the mature karst moves beneath these streams and discharges only at the extreme lower reaches of these streams. Shallow ground-water flow in the headwaters of the Eleven Point River (the western part of the mature karst area) appears to occur at depths as great as $300 \mathrm{ft}$ beneath the streambed surface. The potentiometric map indicates that this 


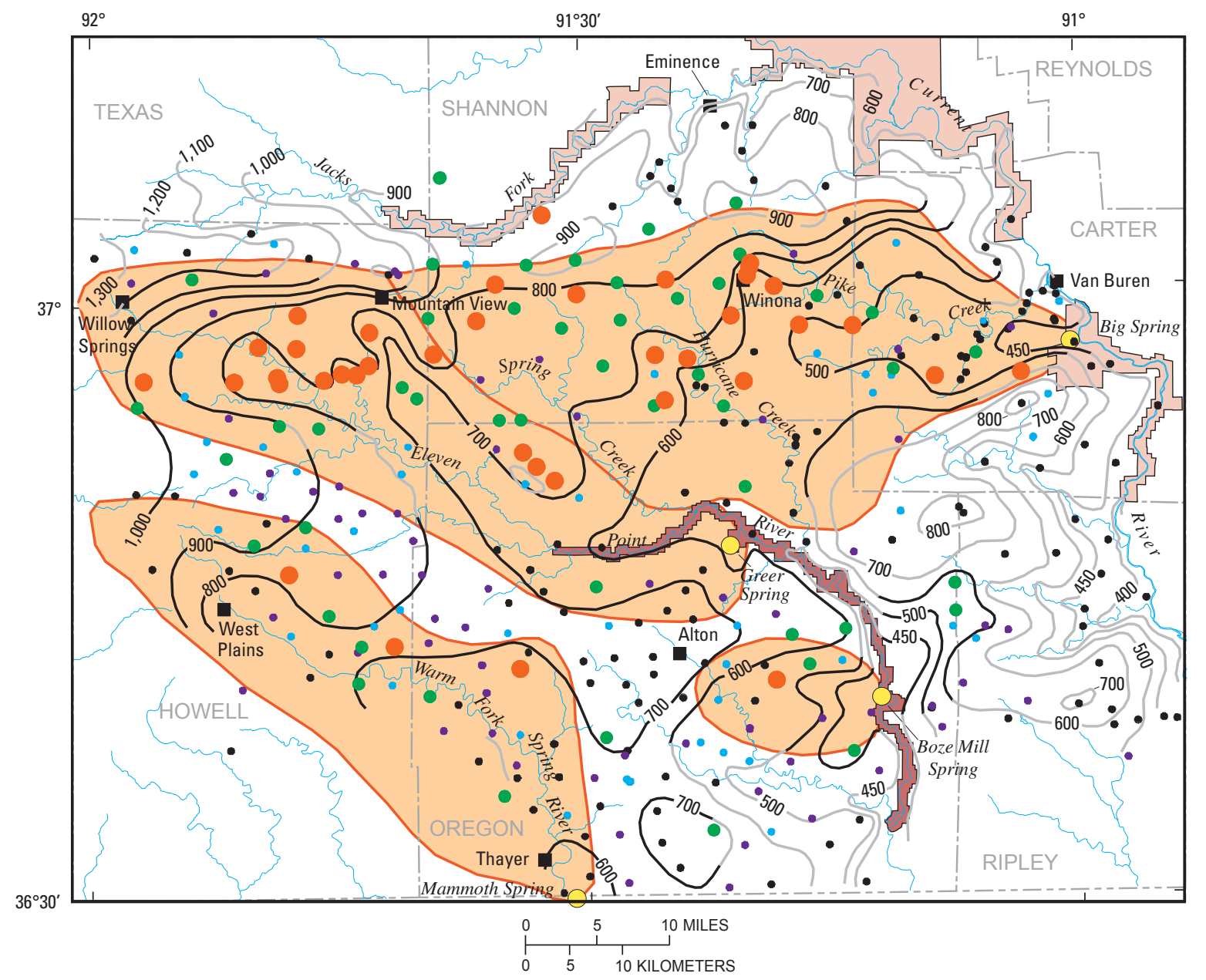

EXPLANATION

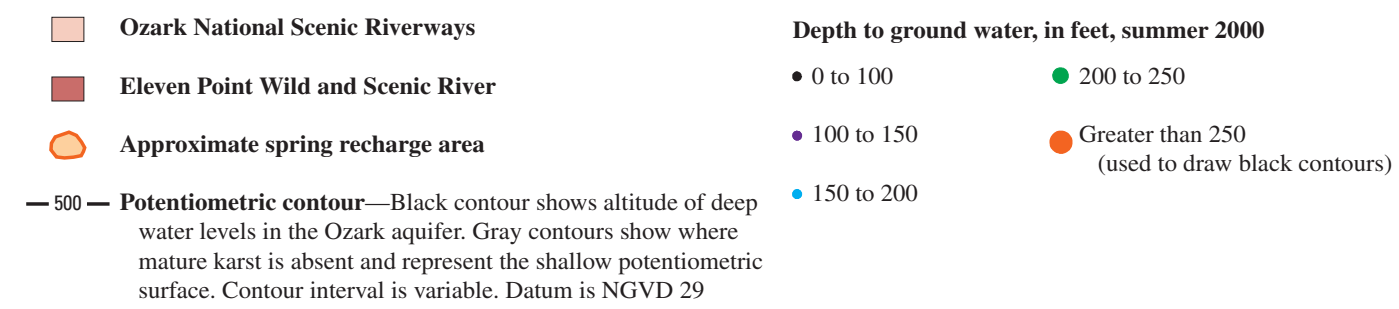

Figure 7. Deep potentiometric surface of the Ozark aquifer, summer 2000.

ground-water flow is toward lower reaches of the Eleven Point River. Shallow ground-water in the Warm Fork Spring River Basin flows into the middle and lower reaches of Warm Fork Spring River.

A deep potentiometric surface (fig. 7) is identifiable with the maturely developed karst areas. In the eastern part of the Big Spring recharge area, a trough (identified by the 500 -ft potentiometric contour) indicates the presence of a deep, highly permeable zone extending about 20 mi west of Big Spring toward the upper Hurricane Creek Basin. The potentiometric head in the western part of this trough area is about 150 to $250 \mathrm{ft}$ lower than the head in the shallower strata, and ground water in the Big Spring recharge area is directed toward this permeable zone and discharges at Big Spring. In contrast, lateral ground-water flow in the shallower strata is toward the lower reach of Pike Creek. In the absence of the mature karst, ground water from the western parts of the Big Spring recharge area would likely flow toward Spring Creek and Hurricane Creek. Increased permeability associated with the mature karst causes deeper ground water to flow more easterly beneath the upper reaches of Spring Creek and Hurricane Creek toward the deep ground-water trough to discharge at Big Spring. 
Indications are of a deep, highly permeable zone (defined by the 600 -ft through 800 -ft contours) extending about $10 \mathrm{mi}$ west of Greer Spring, then trends to the northwest about $20 \mathrm{mi}$ to an area of intensive karst development between and south of Willow Springs and Mountain View. This area comprises the northwestern end of the long and narrow Greer Spring recharge area. The ground-water trough, associated with this permeable zone appears to approximately parallel the upper dry reaches of the Eleven Point River. Whereas ground water flowing through shallower rocks in northern Howell County converges toward the headwater reaches of the Eleven Point River, deeper flowing ground water converges towards the deep permeable zone in eastern Howell County and eventually discharges at Greer Spring.

Deep flowing water in the Warm Fork Spring River Basin apparently flows beneath the river to discharge at Mammoth Spring. The lack of interbasin transfer of ground water in the Mammoth Spring recharge area (Warm Fork Spring River Basin) may indicate that the karst terrain of this area is not as well developed as in the Big Spring and Greer Spring recharge areas.

The southern one-half of the common boundary of the Big Spring and Greer Spring recharge areas depicted in figures 6 and 7 may not accurately portray the complexities of the ground-water flow pattern. Dye-trace investigations indicate the possibility of overlapping recharge areas in this region. Dye from two traces from the headwater areas of Eleven Point River near Willow Springs in northern Howell County was recovered at Greer Spring, and dye from three traces from the Eleven Point Basin in the northwestern corner of Oregon County was recovered at Big Spring (fig. 4). The straight line paths from the injection to recovery points cross. The traces to Greer Spring were conducted in 1972 and 1975 using fluorescein dye and visual detection methods. The traces to Big Spring were conducted in 1971 and 1972 using fluorescein dye and stained Lycopodium spores (Aley, 1975) using visual detection methods. None of the traces have been verified using state-of-the-art fluorescence detection instruments. The deep potentiometric surface map, measured water levels, and dye-trace data indicate the possibility of a low-gradient ground-water flow path from the lowest reach of Spring Creek and Eleven Point River immediately upstream from Spring Creek (water level at about 600-ft altitude) to the 500-ft contour bounding the deep ground-water trough west of Big Spring. The two lowest measured water levels at Hurricane Creek along this path are 566 and $579 \mathrm{ft}$, which is consistent with the possibility of flow to the northeast between these areas. However, the available data are not sufficient to map the potentiometric head in this area with the accuracy necessary to show such a flow path clearly, nor are they sufficient to show the underflow or overflow path that must be present for ground water to flow from the Eleven Point River dye injection sites in northwestern Oregon County to the vicinity of the lower reach of Spring Creek without being captured by the Greer Spring recharge area. More potentiometric head data and successful dye traces in this complex region are required to fully understand the ground-water flow pattern.
Water levels generally decreased across the area from summer to fall 2000 (table 1). Of the 303 wells in table 1 that were measured twice, 277 sites showed a water-level decline. Most of these wells (233 wells) had declines of less than 20 $\mathrm{ft}$ and were scattered evenly throughout the area. However, 29 wells had declines between 20 and $40 \mathrm{ft}$; these sites were concentrated on the western side of the study area in the Warm Fork Spring River Basin and the headwaters of the Eleven Point River. Another 15 wells had declines $40 \mathrm{ft}$ or greater (40 to $141 \mathrm{ft}$ ). Two of these were in the proposed recharge area for either Big Spring or Greer Spring and the rest were primarily in the Warm Fork Spring River Basin. Despite the extremely dry conditions, of the 26 wells that had a water level increase from summer to fall 2000, most of them were in the eastern one-half of the study area. The largest increase was $58.6 \mathrm{ft}$; however, most of these wells (20 wells) had waterlevel increases of less than $20 \mathrm{ft}$. Because the wells that had a water level increase in the fall 2000 water-level measurements were scattered across the study area and essentially isolated from each other, no changes were made to the possible spring recharge areas based on the fall 2000 data.

\section{Physical Characteristics of Big Spring}

The flow from Big Spring has been monitored for several decades using a combination of manual discharge measurements and staff-gage readings. Because of the large size and complexity of the Big Spring flow system and the complexity of the interaction among the spring discharge water, spring branch, and Current River, the accuracy of the discharge estimates made using the spring rating curve and staff measurements vary considerably for different hydrologic conditions. The spring branch was instrumented to continually measure water temperature and specific conductance in October 2000 and water velocity in June 2001. These measurements were analyzed in combination with the standard discharge measurements to provide insights on the nature of the Big Spring flow system and to devise a method to make more accurate discharge estimates.

\section{Measurement of Discharge}

The daily mean Big Spring discharge computation is based on a stage-discharge relation. The daily mean gage height (stage at Big Spring) is measured and then converted to discharge based on discharge measurements made at various gage heights according to methods described by Rantz and others (1982). The USGS, in cooperation with the NPS, has been collecting gage-height and discharge data at Big Spring near Van Buren (USGS station number 07067500) since 1921. Prior to October 1923, the data were published as Big Spring near Chicopee (Hauck and Harris, 2006). Before 1925, the computed daily discharge was derived from discharge measurements and staff readings taken two to three times a week. 
Discharge was interpolated for the days when the staff was not read. Beginning in 1925, an attempt was made to read the staff daily, although through the rest of the 1920's the discharge data were fragmented with many days of missing data. This was either because no staff reading was made for the day or because the staff was in backwater from the Current River during high-flow conditions. By the 1930's, daily discharges were commonly computed for each day. A water-stage recording gage was installed in the spring branch in February 1971 and was maintained until March 1978. However, because of lack of funding, daily staff readings were again used to compute daily discharge for March 1978 until September 1996. Data collection at the spring was discontinued from September 1996 until February 2000, when data collection was again resumed.

The accumulated daily mean discharge of Big Spring was plotted with time for the historic period of record (water years 1922 through 2004) to identify variations in the spring discharge (table 2, at the back of the report; fig. 8). Variations in discharge rates can be caused by land-use changes, extreme or prolonged wet or dry periods, or physical changes in the spring conduit system. The linear regression trend line represents the expected accumulated flow over time if the daily mean discharge were constant every day (mean annual discharge; fig. 8). Data above the trend line indicate an increase in observed discharge compared to expected discharge, and data below the trend line indicate a decrease in observed discharge.

The accumulated daily mean discharge curve shows no substantial change in the discharge pattern of Big Spring during the period of record. However, the spring discharge deviated from the trend line for extended periods. A plot of the accumulated departure from normal precipitation and Big Spring residual discharge (the observed accumulated discharge minus expected accumulated discharge from the linear regression trend line) for water years 1922 through 2004 clarifies the cause of the deviations (fig. 8). Regional annual precipitation summary data (National Oceanic and Atmospheric Administration, 1922-2004) were used when available. On rare occasions when regional data were not reported for the Ozarks Plateaus, Southeast Region, or East Ozarks, more localized rainfall data from the cities of Birch Tree, Van Buren, or Doniphan were used (table 2 and fig. 4). Observed long-term variations in spring discharge can be attributed to prolonged departures from normal precipitation (fig. 8). During extended periods of above normal precipitation, the observed accumulated spring discharge generally is larger than predicted by the trend line, and during prolonged periods of drought, the observed accumulated spring discharge generally is smaller than predicted by the trend line.

Historically, the quality of the computed discharge from Big Spring has been impaired by two factors. During lowflow conditions, especially in the warm summer months, thick watercress beds growing in the spring branch impede the natural movement of the flowing water. This temporary obstruction causes a higher gage-height reading for a particular flow (backwater) than would normally occur during flow conditions without obstructions. Another backwater condition occurs during high-flow conditions in the Current River. The storms that cause the spring flow to increase also typically cause flow to increase in the Current River. Because the spring branch is short $(2,000 \mathrm{ft})$ and the fall between the spring and the river is only about 5 to $6 \mathrm{ft}$, the rising Current River dams water at the mouth of the spring branch during high stages. The spring gaging station on the downstream side of the NPS bridge is affected by backwater after about a 2 -ft rise on the Current River. Consequently, during low flow when the watercress beds are extremely thick in the spring branch and when the Current River has increased flow, the stage-discharge relation is inaccurate.

Gage heights measured at the NPS staff gage located in the spring pool about $400 \mathrm{ft}$ upstream from the USGS gaging station on the NPS bridge from October 2, 2001, to December 17, 2002, clearly shows the backwater effect caused by a rising Current River (fig. 9). The water-level difference (fall) between the NPS staff and USGS gage decreases linearly from about 0.5 to $0.1 \mathrm{ft}$ when the gage height at the NPS bridge ranges from 1.0 to $3.0 \mathrm{ft}$. Above a gage height of $4.0 \mathrm{ft}$ at the bridge, the difference between the water levels at the two locations becomes too small to measure accurately and the spring branch appears to be pooled. The timing of the transition from free-flowing to backwater conditions is dependent on the areal distribution of rainfall in the spring recharge area and river basin and the time when the flow begins to increase in both.

Additional complications caused by backwater from a rising Current River occur when determining Big Spring discharge at gage heights above about $9.5 \mathrm{ft}$ at the bridge. Above this gage height, water from the river flows over its banks about 3,000 ft upstream from Big Spring and enters a shallow slough that lies adjacent to the bluff that bounds the western edge of the Current River alluvial valley (fig. 2). This water flows in the slough toward Big Spring and enters the spring pool immediately downstream from the spring. The slough water (Current River water) mixes with the spring discharge before flowing under the NPS bridge where high-flow discharge measurements are made. Unless the contribution of river flow can be determined and subtracted from the flow measured at the bridge, the spring discharge cannot be accurately determined. When the gage height at the bridge reaches about $11 \mathrm{ft}$, the entire area is inundated, and spring discharge measurements cannot be made by conventional methods.

Determining the maximum flow from the spring because of the backwater effect has been a concern since the beginning of the period of record. Without a discharge measurement, the assigned daily mean discharges were considered to be estimates at best during periods of high gage height. From 1921 until December 1982, the highest estimated daily discharge for the period of record (water years 1922 through 2004) was $1,300 \mathrm{ft}^{3} / \mathrm{s}$ for "sometime in June 1928 during period of backwater from Current River" (Wells, 1955). The largest measured discharge at Big Spring during the period of record was $1,170 \mathrm{ft}^{3} / \mathrm{s}$ on December 7, 1982. Because the gage height had decreased substantially from the peak 4 days earlier, the 

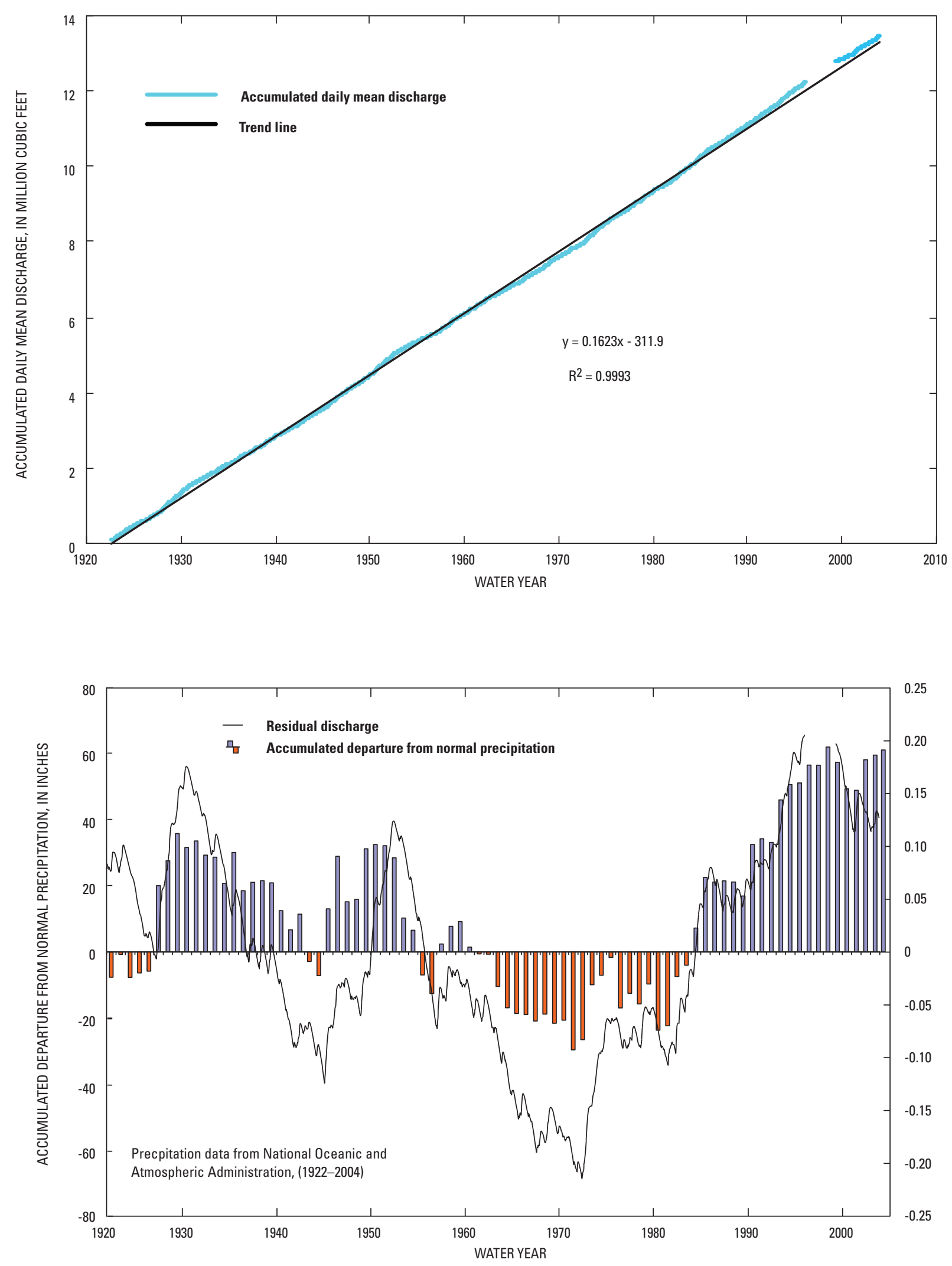

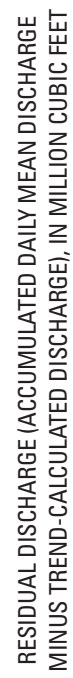

Figure 8. Big Spring accumulated daily mean discharge and residual discharge and accumulated departure from normal precipitation, water years 1922 through 2004. 


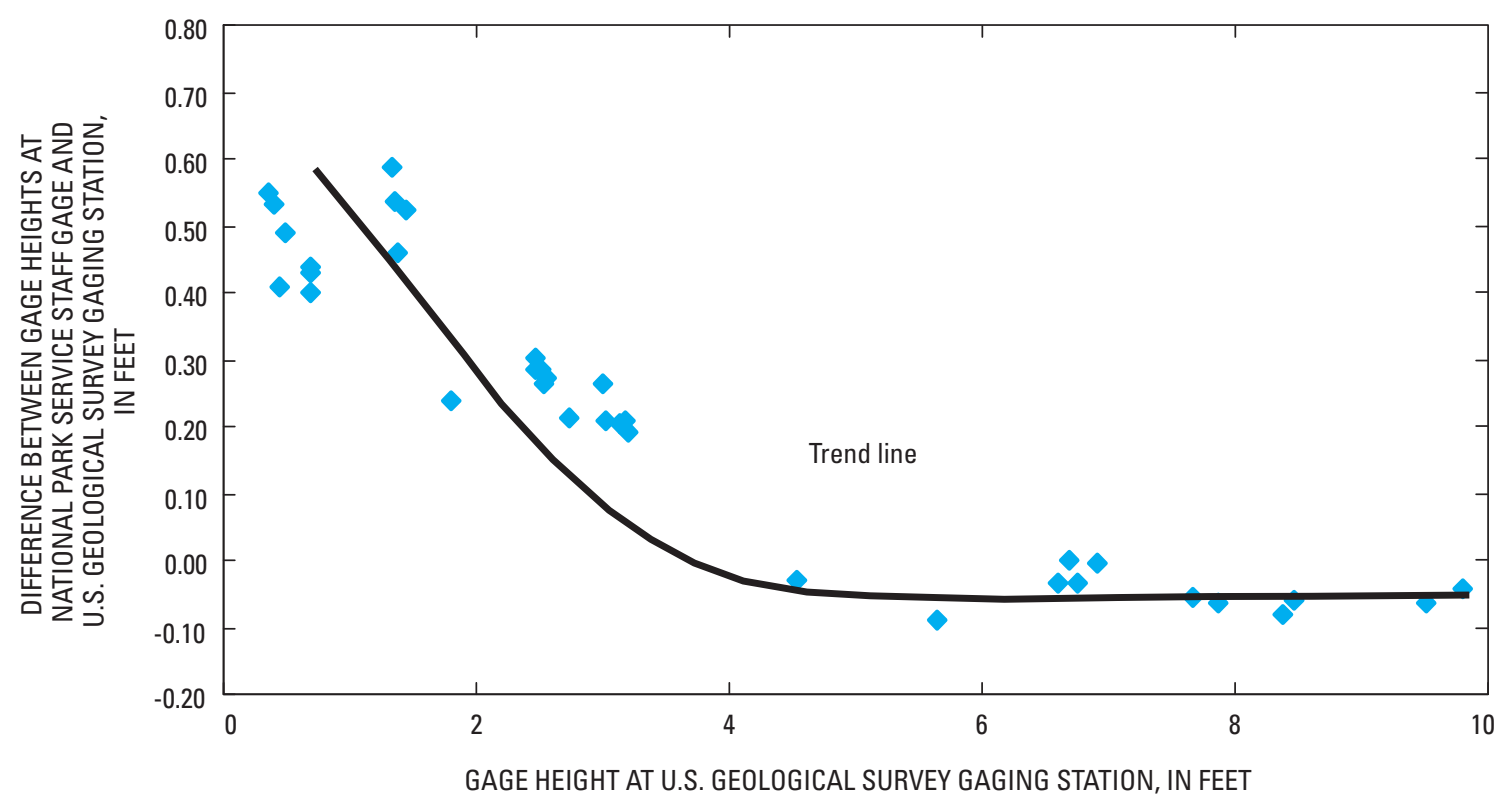

Figure 9. Comparison of gage heights at the National Park Service staff gage and the U.S. Geological Survey gaging station.

discharge also was assumed to have decreased substantially. Therefore, a daily mean discharge of $2,000 \mathrm{ft}^{3} / \mathrm{s}$ was estimated for Big Spring at the peak gage height on December 3, 1982 (Waite and others, 1984). The maximum possible instantaneous flow from Big Spring has not been adequately defined, but physical constraints within the spring conduit system possibly restrict its maximum flow to about $1,200 \mathrm{ft}^{3} / \mathrm{s}$. One seep between Big Spring and the NPS staff gage flows almost continuously. Flow from this smaller seep increases during high flow from Big Spring and resembles an overflow spring during these periods. However, this flow is minimal compared to the flow from Big Spring and is measured as part of the total flow at the gaging station. No other Big Spring overflow springs have been observed.

To better characterize the hydraulic properties and help determine the discharge from Big Spring, the USGS installed an acoustic Doppler system to measure and record stream velocities at the gaging station on the downstream side of the NPS bridge. The acoustic Doppler system emits three acoustic beams directed at different distances along a horizontal plane in the water column. Water velocity is measured by detecting the acoustic backscatter from sediment suspended in the water. The three acoustic Doppler-measured water velocities are measured across the thalweg (deepest part of the stream channel), which is about $15 \mathrm{ft}$ wide and near the east bank. These velocities are averaged and used to represent water velocity in the channel. The cross-sectional area of the spring branch also was measured at the downstream side of the bridge and a stage-area relation was developed. The velocity and gageheight data can be measured and recorded at frequent intervals, converted to discharge, and used to improve the estimates for the spring discharge when no manual discharge measurements are available.
At low stage, acoustic Doppler-measured water velocities through the thalweg are about $2.5 \mathrm{ft} / \mathrm{s}$ (feet per second; fig. 10). The velocity data show considerable scatter for gage heights less than about $3.0 \mathrm{ft}$ because of the presence of watercress in the channel. Above about 3.0-ft gage height, water velocities drop abruptly to about $1.5 \mathrm{ft} / \mathrm{s}$ as the backwater effect caused by the Current River stage propagates up the spring branch and reaches the bridge. Above about 3.5-ft gage height, water velocity in the channel decreases linearly with increasing gage height.

A mean water velocity for the channel was calculated from measured discharge divided by cross sectional area as determined from measured stage using the stage-area relation. Comparison of this mean velocity to the velocity measured by the acoustic Doppler unit shows that the calculated mean velocity for the channel is smaller than measured acoustic Doppler velocity when bridge stage is lower than about $3.0 \mathrm{ft}$. The difference in velocities ranged from -1.00 to $-0.50 \mathrm{ft} / \mathrm{s}$ and reflects the higher velocities in the thalweg because it conveys a high proportion of the water during low flow. At higher stage (from about $6.0 \mathrm{ft}$ to nearly $10 \mathrm{ft}$ ), the calculated mean velocity is uniformly larger than the acoustic Doppler velocity by about 0.10 to $0.20 \mathrm{ft} / \mathrm{s}$. In this stage range, the higher velocities shift from the thalweg to the middle of the channel, which now conveys a higher proportion of the flow.

The value of the acoustic Doppler velocity data for determining a universal correction to the stage-discharge rating is equivocal. The relation between gage height and the recorded acoustic Doppler water velocity at the USGS gaging station as seen across many hydrologic conditions shows a non-unique behavior (fig. 11). The data were tabulated every 6 hours from February 1, 2002, to January 23, 2004. Different hydrologic events show slightly different relations between gage height 


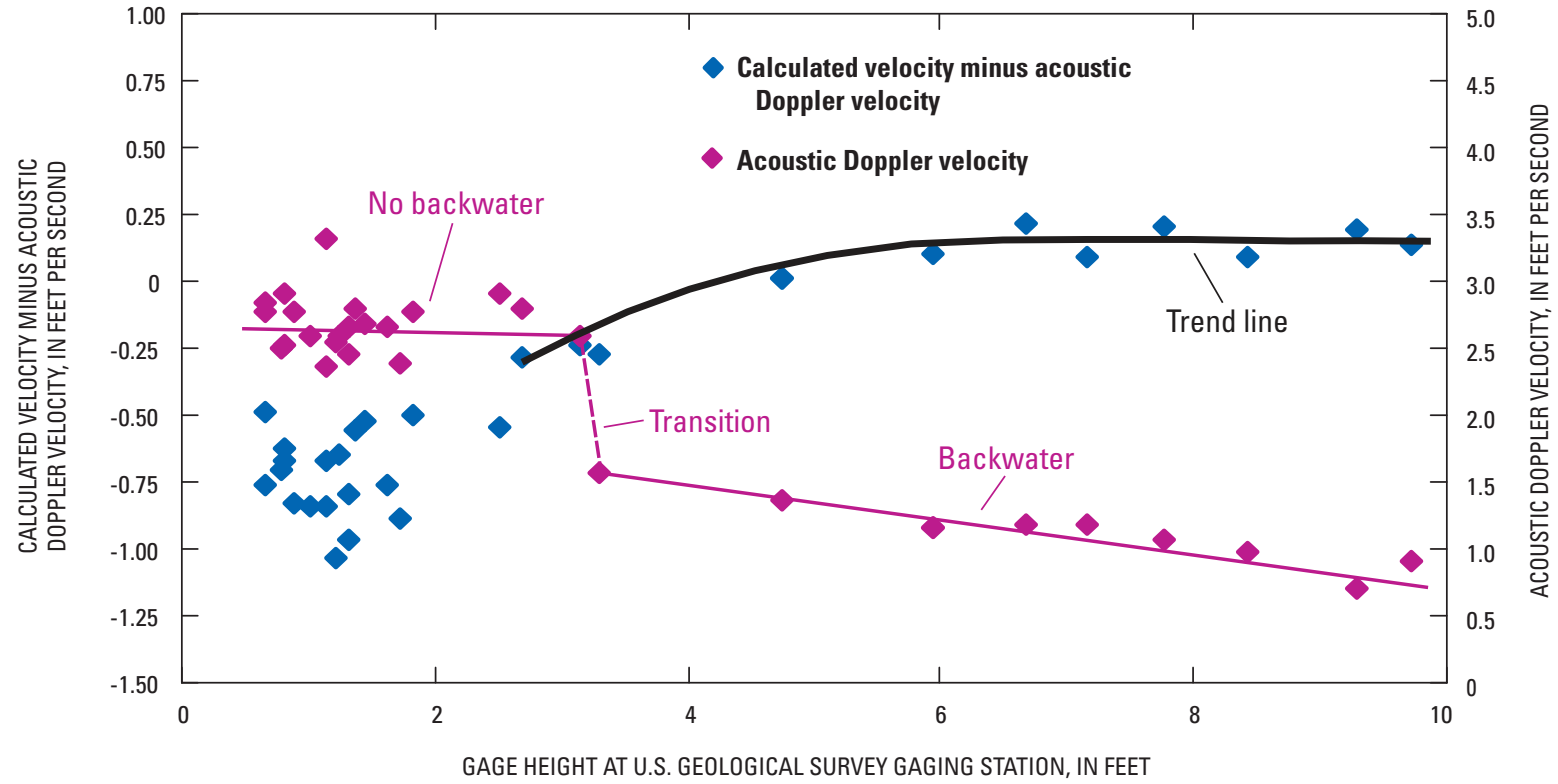

Figure 10. Relation between water velocity and gage height in the Big Spring branch at the U.S. Geological Survey gaging station.

and velocity, although the general trend is that higher spring branch gage heights correspond to smaller measured acoustic Doppler water velocities. During high flow at Big Spring and the Current River, the discharge of Big Spring increases well before flow increases in the Current River adjacent to the spring branch. During this period, no backwater occurs in the spring branch and the stage in the spring branch slowly rises in response to the increased flow from the spring. Hours later, the flow in the Current River at the mouth of the spring branch begins to rapidly increase, causing the stage of the spring branch to rise quickly and eventually causing backwater conditions in the spring branch. During this period of rapid stage increase in both the river and the spring branch, the spring discharge does not substantially change, even though

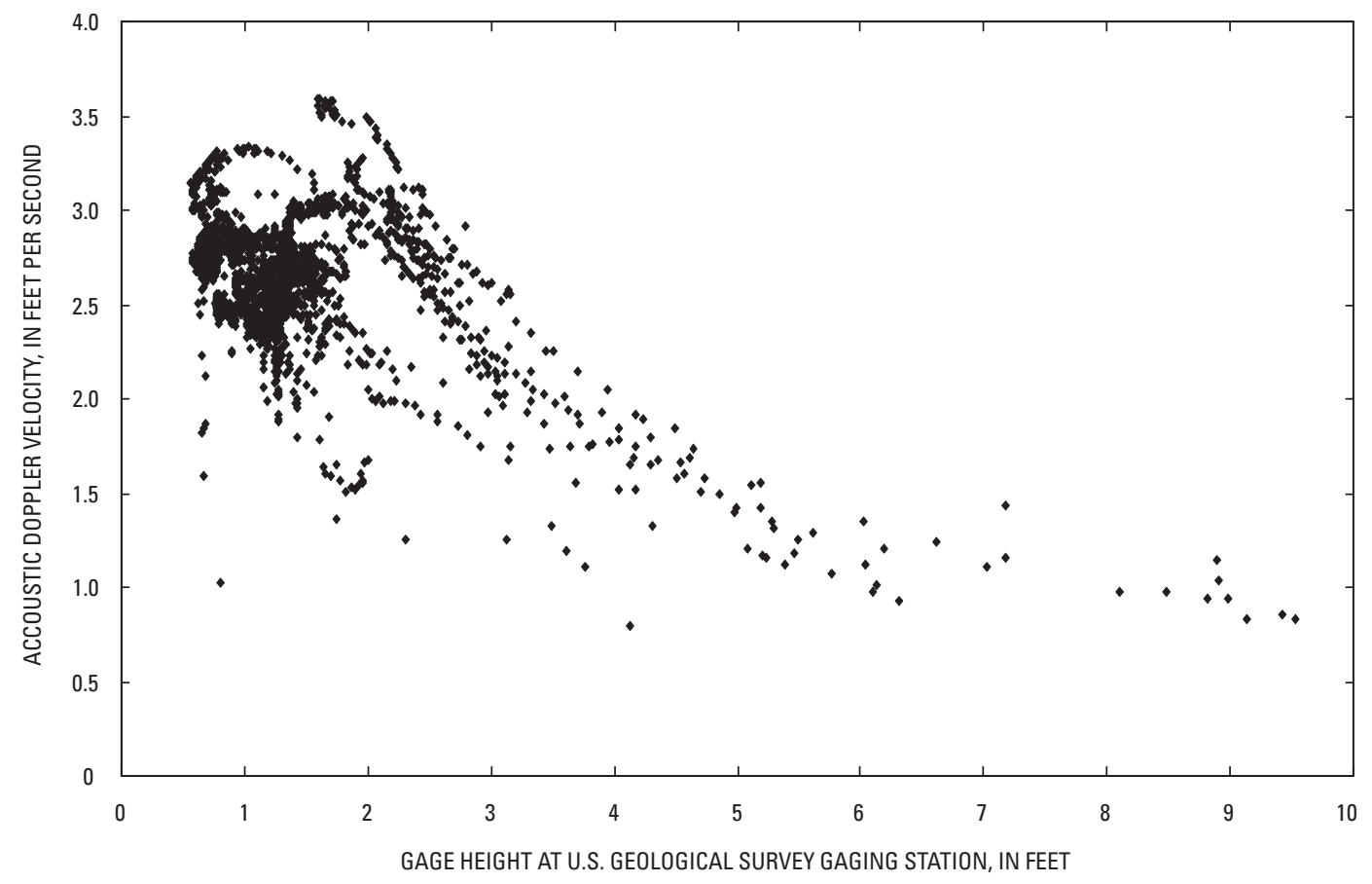

Figure 11. Gage height and average acoustic Doppler velocity recorded in 6-hour time increments from February 1, 2002, to January 23, 2004. 
the cross-sectional flow area in the spring branch dramatically increases in response to the backwater. The result is that the recorded spring branch velocities begin to decrease even though the flow from Big Spring is increasing slightly or remaining constant.

The variation between stream velocity and gage height for individual hydrologic events likely occurs because of variable timing between the increase in flow from Big Spring and the rise of the Current River at the mouth of the spring branch. The timing is affected by differences in the initial conditions encountered at the onset of each period of high rainfall and the distribution of rainfall within the Big Spring recharge area and the Current River Basin. Consequently, each event is unique. However, for spring branch stages above 3.5 to $4.0 \mathrm{ft}$ (when the backwater effect is at its greatest), the relation between stage and water velocities is more uniform, and the acoustic Doppler velocity data may be used as an aid to refine discharge data normally derived directly from the stage-discharge curve for Big Spring.

\section{Temperature of Ground Water Discharging from Big Spring}

In October 2000, a water temperature and specific conductance monitor was installed at the USGS gaging station at the spring branch. Even though the gage is $800 \mathrm{ft}$ downstream from the spring orifice, water temperature difference at the gage and orifice generally is $0.2{ }^{\circ} \mathrm{C}$ (degree Celsius) or less (table 3 , at the back of the report). The daily mean water temperature for the water years 2001 through 2004 (October 2000 through September 2004) had little variability ranging from 13 to $15^{\circ} \mathrm{C}$ (fig. 12). The lower daily mean water temperatures (13.1 to $13.5^{\circ} \mathrm{C}$ ) were recorded from March to April 2002. This was a period of above normal precipitation and flooding of the Current River. Floodwater from the Current River flowed into the spring branch upstream from the monitor during March 20 to 21, 2002. On March 21, the daily mean water temperature was less than $13.5^{\circ} \mathrm{C}$ and stayed below $13.5^{\circ} \mathrm{C}$ until May 1, 2002. Even though spring and river water mixed for less than a day, the water temperature stayed abnormally low for nearly 6 weeks. During this period, there were other storm events that caused increased spring flow and consequently lower spring water temperatures. During several periods from May 8 to 19, 2002, flood waters mixed with spring water upstream from the monitor; however, water temperatures were not less than $13.5^{\circ} \mathrm{C}$ at any time during this period, probably because of the higher ambient temperatures.

The daily mean spring water temperature dropped below $14.0^{\circ} \mathrm{C}$ several times during the 2001 to 2004 water years, and each incident was during or immediately following intense storms that occurred during the winter or spring. Not all of these incidents had mixing of river flood and spring water; consequently, spring water temperatures less then $14.0^{\circ} \mathrm{C}$ appear to be the result of recharge from storms occurring during periods of cold ambient air temperatures.
The mean monthly and daily mean water temperatures for Big Spring during the water years 2001 to 2004 show the temperatures normally vary less than $1^{\circ} \mathrm{C}$ throughout the year (fig. 12). The warmest temperatures occur during October and November, traditionally low-flow periods, and the temperature decreases until April at which time water temperatures begin to increase. Because the period of temperature determination is short, the abnormally low temperatures during March and April 2002 have an overriding effect on the general shape of the graph. Without these low temperatures, the mean monthly for March and April would be higher. Nevertheless, Big Spring water temperature does show a slight seasonal variation.

\section{Specific Conductance of Ground Water Discharging from Big Spring}

Specific conductance is a measure of the ability of water to conduct electric current (Hem, 1992). Because current is conducted in water by dissolved chemicals, specific conductance is proportional to the TDS (total dissolved solids) concentration present in water. Specific conductance also is temperature dependent, so it is commonly standardized to the conductance at $25^{\circ} \mathrm{C}$ to facilitate comparison of measurements made at different temperatures. The specific conductance of water flowing from Big Spring is a result of the mixing of waters of different specific conductance. Water that has moved more slowly through the karst terrain and surrounding bedrock in the Big Spring recharge area accumulates dissolved solids to an equilibrium concentration that yields higher specific conductance values than water that moves more quickly through the larger fractures and conduits of the recharge area in response to intense rainfall.

The specific conductance of water discharging from Big Spring (fig. 13) was continually monitored beginning in October 2000 at 15 -minute intervals by a water-quality monitor in the USGS gaging station on the NPS bridge. These values were compared to specific conductance values that were manually measured by field personnel during site visits using a portable conductivity meter with temperature compensation designed to express readings in microsiemens per centimeter at $25{ }^{\circ} \mathrm{C}(\mu \mathrm{S} / \mathrm{cm})$. The manual specific conductance measurements were considered the standard and were used to verify the accuracy of the water-quality monitor, which was adjusted as necessary.

During extended periods of little rainfall or moderate rainfall insufficient to cause measurable increase in spring discharge, the specific conductance of the spring water stabilized at about $357 \mu \mathrm{S} / \mathrm{cm}$. This conductance is representative of ground water that has remained in the smaller fractures of the rock matrix in the Big Spring recharge area for sufficient time to establish chemical equilibrium with the surrounding bedrock. The equilibrium conductance was measured during much of the last 14 months of an extended dry period that ended in the fall of 2001. During intervals of intense rainfall or 

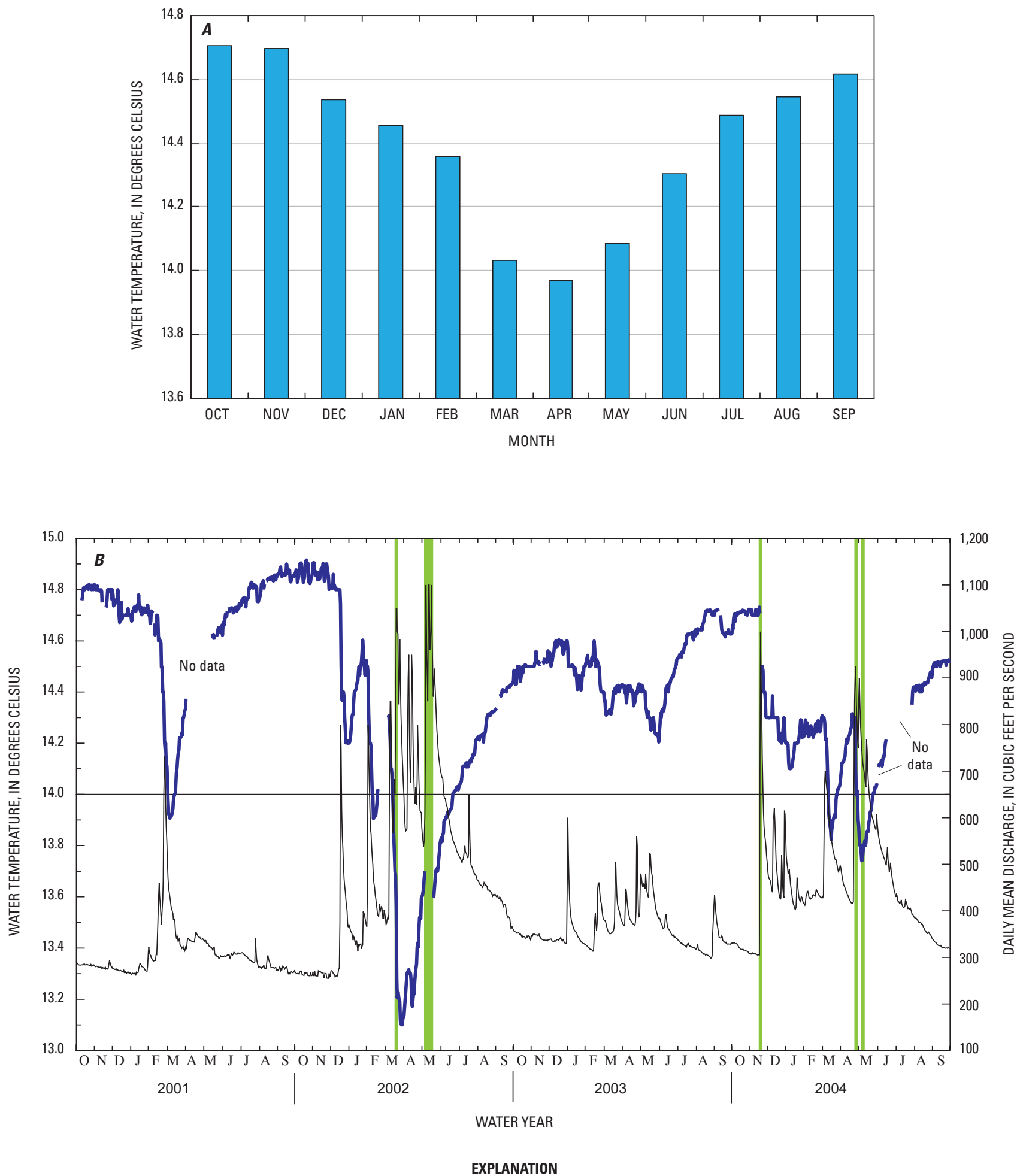

Figure 12. Big Spring mean monthly $(A)$ and daily mean water temperatures and daily mean discharge $(B)$ for water years $2001-04$. 
Recharge Area, Discharge Rates and Ages, and Water Quality of Big Spring in Carter County, Missouri, 2000-04

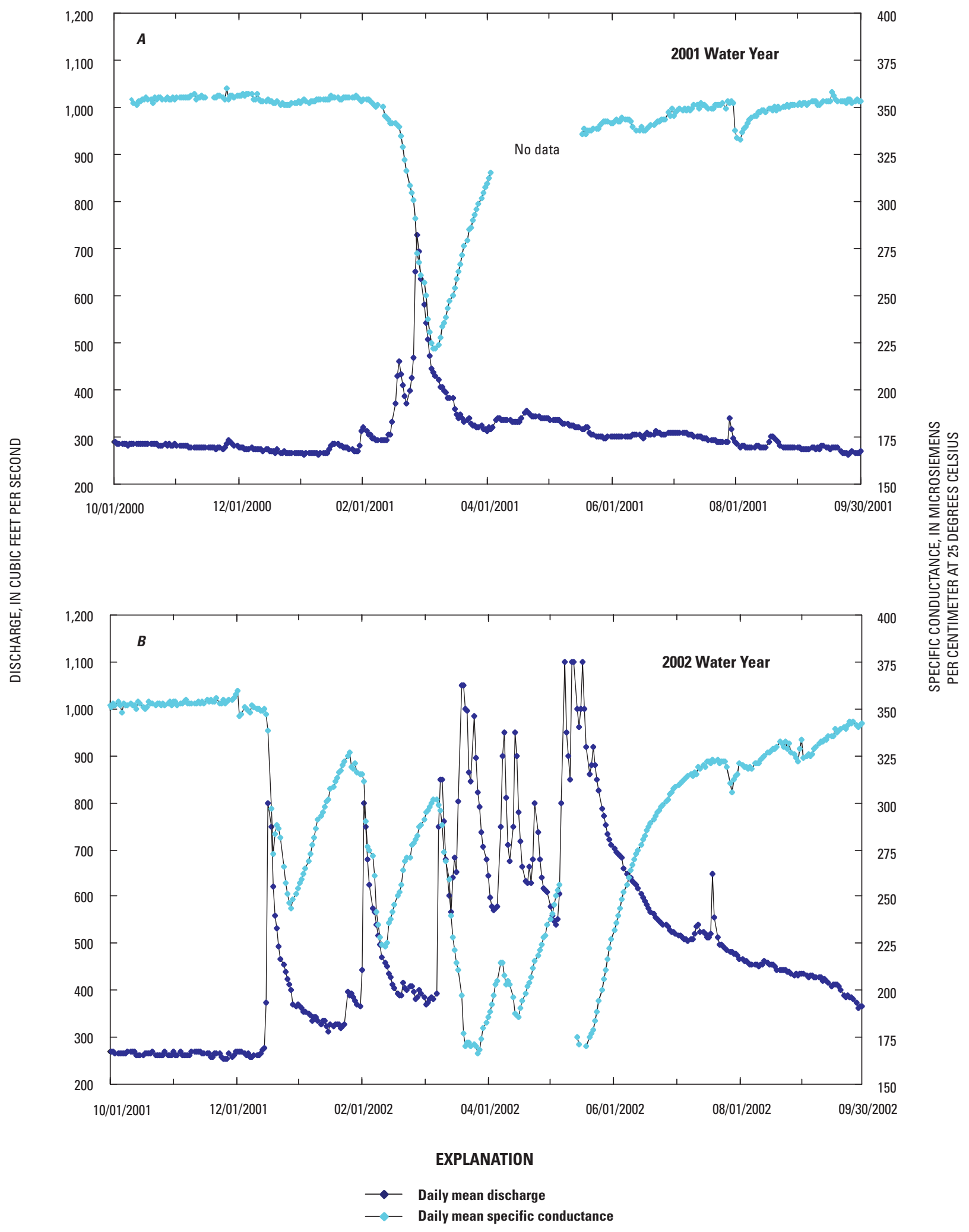

Figure 13. Big Spring daily mean discharge and specific conductance for water years 2001-04. 


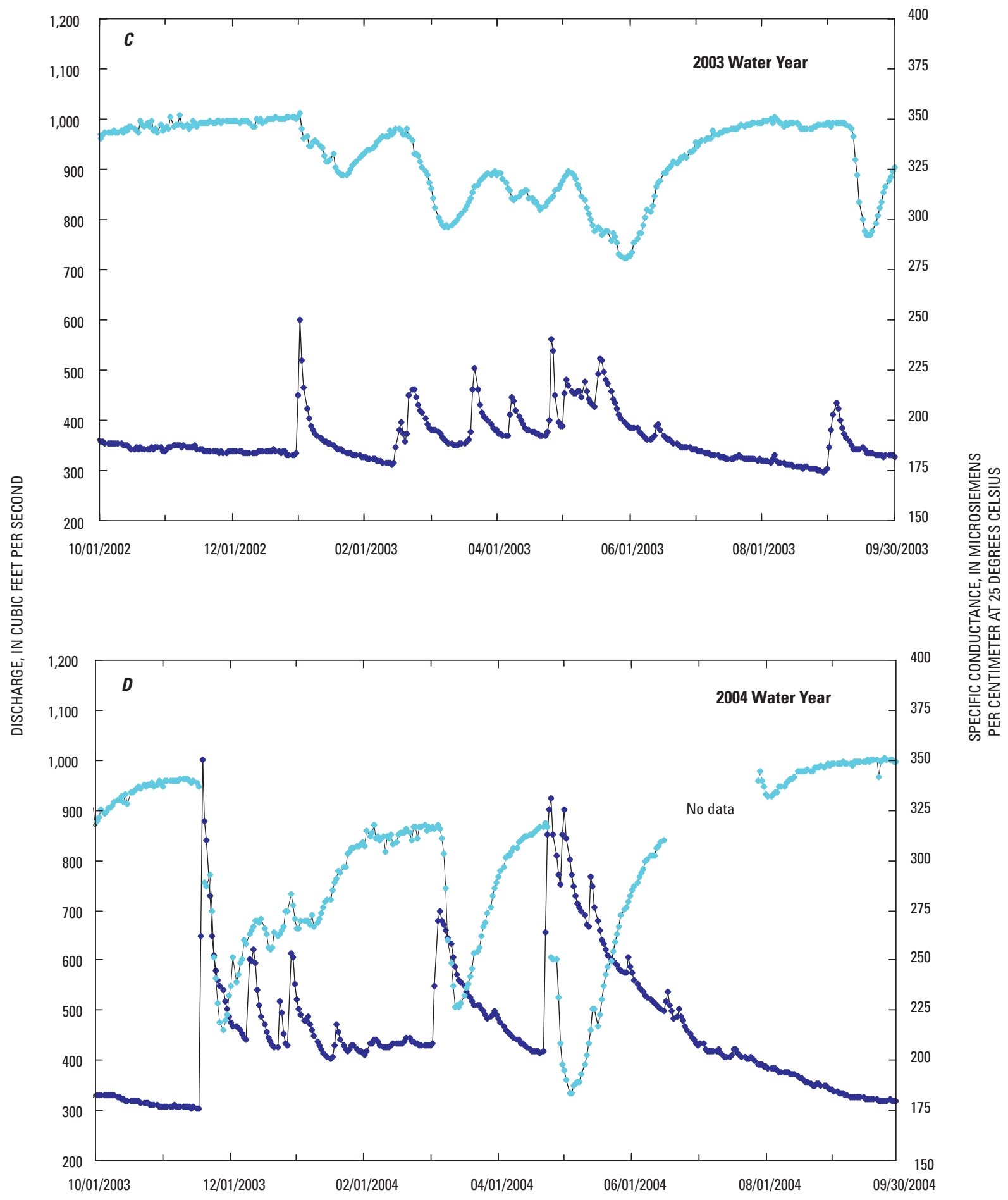

Figure 13. Big Spring daily mean discharge and specific conductance for water years 2001-04.-Continued 
prolonged periods of moderate rainfall, water of lower specific conductance that enters the larger fractures and conduits in the Big Spring recharge area quickly moves toward the spring orifice and discharges before reaching chemical equilibrium with the surrounding rock. The specific conductance of the ground water that discharges at the spring decreases as the ratio of quick-flowing water in the large fractures and conduits increases relative to the slower-flowing water in the smaller fractures. Depending on the amount and areal distribution of rainfall, the decrease in specific conductance values can be abrupt and short-lived or a complex series of increasing and decreasing values.

A short period of intense rainfall in late February and early March 2001 caused the specific conductance values of the spring water to decrease abruptly to about $220 \mu \mathrm{S} / \mathrm{cm}$, and then recover to pre-rainfall levels (fig. 13A). A series of intense storms from mid-December 2001 to May 2002 caused specific conductance values to alternately decrease and recover (fig. 13B). However, the specific conductance values never fully recovered to pre-storm levels in the intervals between storms, and the specific conductance values oscillated several times during the period, attaining the lowest value of $170 \mu \mathrm{S} / \mathrm{cm}$ in late March 2002. Lighter or less intense rainfall in the recharge area results in a smaller fraction of low specific conductance water in the system causing less abrupt and minor decreases in specific conductance values of the spring water. This is demonstrated by the smaller decreases in specific conductance values during January 2003 through June 2003 (fig. 13C) as compared to February 2002 through June 2002. Even during prolonged periods of lighter rainfall, the specific conductance values do not recover to pre-storm values between storm events. Observation of the rise in specific conductance after a rainfall-induced decline shows that the recovery is slow and that the specific conductance approaches pre-storm values exponentially with time.

\section{Base-Flow and Quick-Flow Components of Big Spring Discharge}

Base flow has traditionally been associated with groundwater discharge to streams and is defined herein as the component of spring flow derived from water that has traveled through smaller fractures and pore space in the bedrock. Base flow has a long traveltime from recharge area to the spring and rates typically decrease gradually and slowly under dry conditions. Base flow is characterized by higher specific conductance than quick flow. Quick flow is associated with storm events and is defined herein as the component of spring flow derived from water that has traveled through larger fractures and conduits as a result of rapid recharge of recent rainfall. Quick flow, therefore, has a shorter traveltime from recharge area to the spring, and flow rates vary rapidly under hydrologic conditions caused by storms. Hydrograph separation, or the extraction of base-flow and quick-flow components from a time-discharge relation for a spring, can provide clues about the mechanism by which the water moves through the spring flow system. However, hydrograph separation techniques involve many assumptions and can be difficult to apply accurately.

\section{Dye-Trace Estimates of Quick-Flow Traveltime}

Fluorescent tracer dyes have been used to ascertain the hydraulic connection between Big Spring and losing streams or sink holes in its probable recharge area for at least 35 years (Aley, 1975). When injected tracer dye is detected at a monitored spring, the calculated traveltimes and distances provide information about the quick-flow component of the spring discharge. Dye mixing with the ground water that forms the base-flow component of a spring, chemical degradation occurring during extremely long traveltimes, adherence of dye to rock and clay surfaces, and substantial dilution can all greatly decrease the amount of dye detected at the monitored spring. Results of some of these dye-trace tests have been reported in Aley (1975) and Imes and Fredrick (2002), and many more results are stored in unpublished data files at the USGS and Missouri Department of Natural Resources, Division of Geology and Land Survey offices in Rolla, Missouri. As part of this study, several dye-trace investigations were conducted to better define the common boundary between Big Spring and Greer Spring. Three dye-trace tests that were conducted are described herein because they demonstrate the range of quickflow traveltimes observed in the large Big Spring recharge area.

Pike Creek is a tributary of the Current River that drains the eastern side of the Big Spring recharge area (fig. 4) and enters the Current River about 7 mi north of Big Spring. The creek normally is dry except for the lowermost reach. Ten pounds of fluorescein dye were injected into the creek bed at an altitude of $910 \mathrm{ft}$ on May 10, 1973, and subsequently detected visually in Big Spring about $18.8 \mathrm{mi}$ from the injection site (Missouri Department of Natural Resources, Division of Geology and Land Survey, written commun., 2004). Dye was visually detected in the solvent used to elute the adsorbed dye from the charcoal packets that were placed at Big Spring from May 16 to May 22, 1973. Because of the weekly replacement schedule for the charcoal packets, the range for the traveltime for the dye to reach Big Spring was 6 to 12 days, and the quick-flow velocity was approximately 1.5 to $3.0 \mathrm{mi} / \mathrm{d}$ (miles per day).

Two dye-trace tests were conducted after storms occurred and during runoff at a small spring (Barrett Spring) in the Hurricane Creek Basin (fig. 6), a major dry and losing stream valley in the central part of the Big Spring recharge area (fig. 4). Both injection locations were about $16 \mathrm{mi}$ from Big Spring at an altitude of about $630 \mathrm{ft}$. The first test was started on January 31, 2002, when 4 pounds of Rhodamine-WT dye was placed in the Barrett Spring Branch. The spring water and dye traveled about $50 \mathrm{ft}$ to the dry bed of Hurricane Creek, before percolating through the gravel into the karstic dolostone. Water samples were collected from Big Spring by an automatic sampler at the USGS gaging station on the NPS 
bridge from January 31 to March 7, 2002, at intervals ranging from 12 to 28 hours. The samples were analyzed in a scanning spectrofluorophotometer for the presence of fluorescence emission spectra characteristic of the injection dye. The peak concentration of the dye (fig. 14) was detected in a water sample collected from Big Spring on February 10, a traveltime of about 11 days, and a quick-flow rate of about $1.5 \mathrm{mi} / \mathrm{d}$. The second test was started on March 8, 2002, with the injection of 2 pounds of Rhodamine-WT dye in the flow of Barrett Spring. The dye was again carried about $50 \mathrm{ft}$ to the dry bed of Hurricane Creek, where it percolated through the gravel into the karstic dolostone. Water samples were collected from Big Spring from March 8 to March 27, 2002, and analyzed using similar techniques as the first injection. The peak dye concentration in the water samples (fig. 14) was detected on March 16 , after traveling about 8 days at a flow rate of about $2 \mathrm{mi} / \mathrm{d}$. The dye-detection methods and quantification of recovered dye are discussed in more detail in Imes and Fredrick (2002).

A dye-trace test was conducted from the vicinity of Mountain View (fig. 4) on July 10, 2001, after the accidental discharge of approximately 50,000 gallons of partially treated wastewater into nearby Jam Up Creek (fig. 4; Imes and Fredrick, 2002). Four and one-half pounds of RhodamineWT dye were placed into Jam Up Creek downstream from the Mountain View wastewater-treatment plant. The injection site is $38 \mathrm{mi}$ from Big Spring and near the western edge of the Big Spring recharge area at an altitude of about 1,100 ft. Jam Up Creek flowed at about $0.5 \mathrm{ft}^{3} / \mathrm{s}$ at the injection site, but lost the entire flow into the subsurface within a mile of the injection site. Water samples were collected at 12- to 24-hour intervals using the automatic water sampler at Big Spring and analyzed for the presence of dye using a scanning spectrofluorophotometer. Dye was detected in the water samples from about August 12 until about September 20, and the peak dye concentrations in the water samples occurred on August 21. Based on the peak dye intensity (fig. 14), the dye traveled a distance of $38 \mathrm{mi}$ in 42 days, corresponding to an average flow rate of $0.9 \mathrm{mi} / \mathrm{d}$.

These and other dye-trace tests indicate that the quickflow traveltimes from various parts of the recharge area where precipitation can rapidly enter the karst system can range from a week to nearly a month and a half. Average flow rates for the quick-flow component can range from slightly less than 1 to 3 $\mathrm{mi} / \mathrm{d}$. The Hurricane Creek Basin occupies much of the central part of the Big Spring recharge area, and runoff during large storms is concentrated in a permeable streambed that permits rapid transport of large quantities of water into the groundwater flow system. Thus, a substantial part of the quick-flow

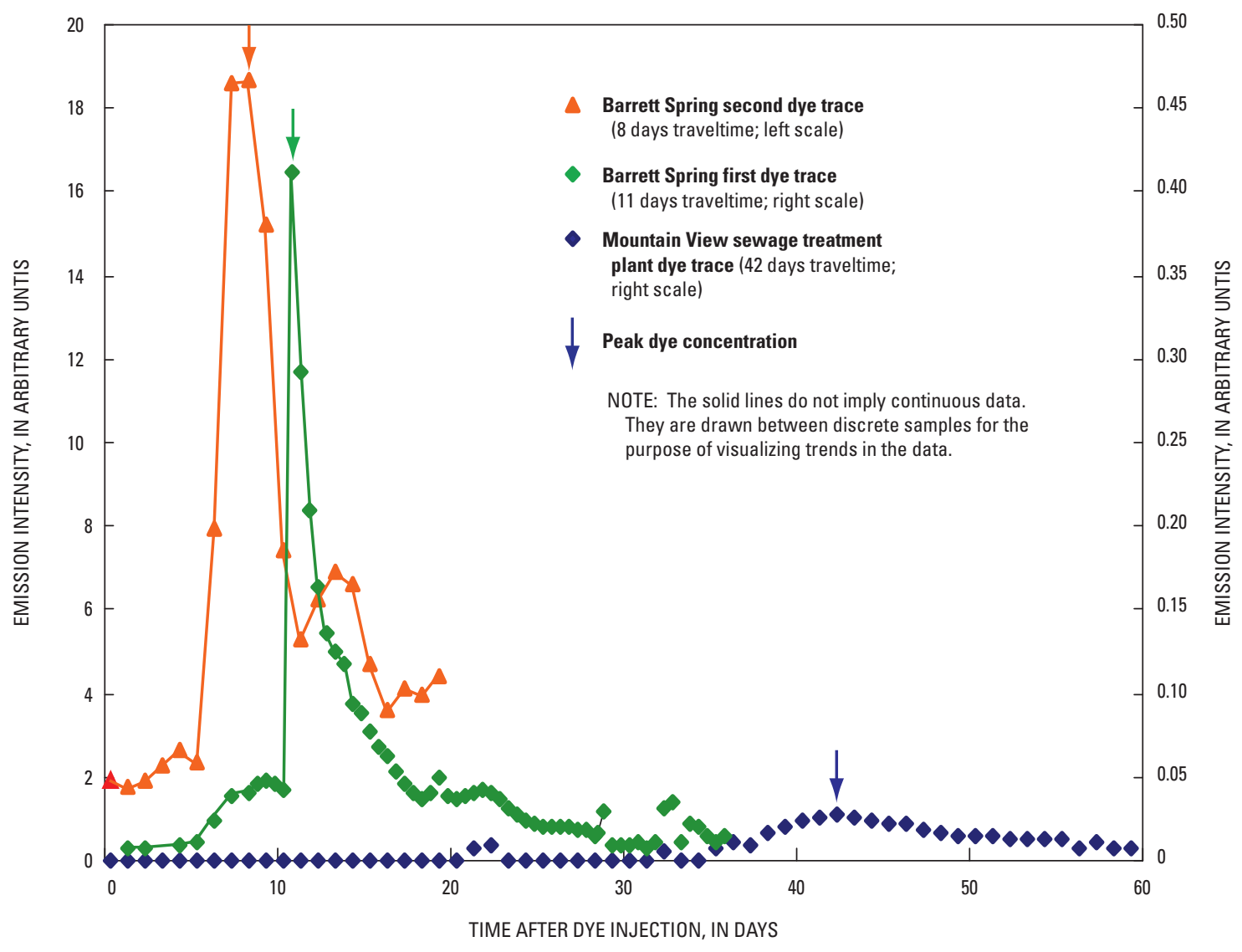

Figure 14. Emission intensity of dye in water samples collected from Big Spring as a function of time after dye injection. 
component of Big Spring when rainfall is distributed throughout the recharge area is derived from recharge in the Hurricane Creek Basin. This quick-flow component arrives at Big Spring within about 8 to 11 days after the recharge occurs.

\section{Separation of Base Flow and Quick Flow using HYSEP}

The computer program HYSEP was used to separate the Big Spring hydrograph into base-flow and quick-flow components (fig.15). HYSEP, which was developed to separate base-flow and surface-runoff components of a streamflow hydrograph, uses one of three possible algorithms to smoothly connect the low points along the hydrograph (Sloto and Crouse,1996; Rutledge, 1998). The local-minimum method was used to execute the HYSEP analysis. The area below the connecting line defines the base flow of the stream. The variables used in the computer programs included the daily mean discharge of Big Spring for water years 2001 to 2004 and an assigned recharge area of $426 \mathrm{mi}^{2}$.

The HYSEP analysis indicates that base-flow discharge at Big Spring is the source of water that sustains spring flow, and the quick-flow discharge is small compared to the base-flow discharge. During water year 2001, Big Spring discharge was mostly base flow (fig. 15A). HYSEP analysis of a rain-induced spike in spring discharge in late February 2001 showed base-flow discharge peaking several days before the total discharge, and quick-flow discharge peaking the same day as spring discharge. Quick-flow discharge is more than 50 percent of total discharge at the discharge hydrograph peak. Base flow declines approximately linearly for about 40 days after peak values, and quick-flow discharge declines abruptly from peak values. The characteristics of the base-flow and quick-flow analysis for other discharge peaks during water years 2001 to 2004 are quite similar, whether the discharge peaks are caused by isolated storms or a rapid sequence of storms, except that the base flow may be linearly increasing or linearly decreasing as the discharge hydrograph rises and falls in response to a storm. The slope of the linear base-flow segments is dependent on the time between two successive rises in the discharge hydrograph.

\section{Separation of Base-Flow and Quick-Flow Components using Discharge and Specific Conductance}

Big Spring discharge data were used in combination with specific conductance data to develop an improved hydrograph separation method to estimate the base-flow and quick-flow components of the spring discharge. The TDS concentrations of water discharging from Big Spring is a result of the mixing of a base-flow component containing higher concentrations of dissolved minerals and a quick-flow component containing lower concentrations of dissolved minerals. Nineteen spring- water samples were collected for chemical analysis from March 2000 through August 2002 at various spring discharge rates. A regression analysis of the specific conductance of the spring water samples and laboratory determinations of their TDS concentrations indicates a linear relation $\left(r^{2}\right.$ value of 0.98). Therefore, specific conductance can be used as a surrogate for TDS concentrations in a mass-balance equation that describes the mixing process of the two components. The following relations describe the discharge rate and specific conductance of the spring water at any point in time:

$$
\begin{gathered}
\mathrm{Qs}=\mathrm{Qb}+\mathrm{Qq} \\
\mathrm{Qs} * \mathrm{Cs}=\mathrm{Qb} * \mathrm{Cb}+\mathrm{Qq} * \mathrm{Cq}
\end{gathered}
$$

where,

$$
\begin{aligned}
& \text { Qs is spring discharge, in cubic feet per second; } \\
& \text { Qb is base-flow component of spring discharge, } \\
& \text { in cubic feet per second; } \\
& \text { Qq is quick-flow component of spring discharge, } \\
& \text { in cubic feet per second; } \\
& \text { is specific conductance of the spring water, in } \\
& \text { microsiemens per centimeter at } 25 \text { degrees } \\
& \text { Celsius; } \\
& \text { is specific conductance of base-flow } \\
& \text { component of spring discharge in } \\
& \text { microsiemens per centimeter at } 25 \text { degrees } \\
& \text { Celsius; and } \\
& \text { is specific conductance of quick-flow } \\
& \text { component of spring discharge in } \\
& \text { microsiemens per centimeter at } 25 \text { degrees } \\
& \text { Celsius; }
\end{aligned}
$$

The specific conductance of the base-flow component was estimated at $357 \mu \mathrm{S} / \mathrm{cm}$ using the highest measured specific conductance at Big Spring in November 2000 (table 3 ) near the end of a prolonged dry period. The specific conductance of the quick-flow component was estimated at $100 \mu \mathrm{S} / \mathrm{cm}$ based on the experience of hydrologic technicians familiar with water-quality sampling of streams in the carbonate bedrock terrain of southern Missouri during storms (R.E. Whitaker, U.S. Geological Survey; oral commun., 2004). Equations 1 and 2 can be combined and the estimated specific conductance values inserted to yield the following equations:

$$
\begin{gathered}
\mathrm{Qb}=\mathrm{Qs} *(\mathrm{Cs}-100) /(357-100) \\
\mathrm{Qq}=\mathrm{Qs}-\mathrm{Qb}
\end{gathered}
$$

Equation 3 was applied to the daily mean discharge and specific conductance data at Big Spring for the water years 2001 to 2004 to calculate the base-flow and quick-flow components of spring discharge (fig. 16). Quick flow commonly is the smaller component of the spring discharge except when unusually large or sustained storms cause the spring discharge to exceed about $800 \mathrm{ft}^{3} / \mathrm{s}$. Big Spring discharge during water year 2001 was generally near base-flow levels except in 


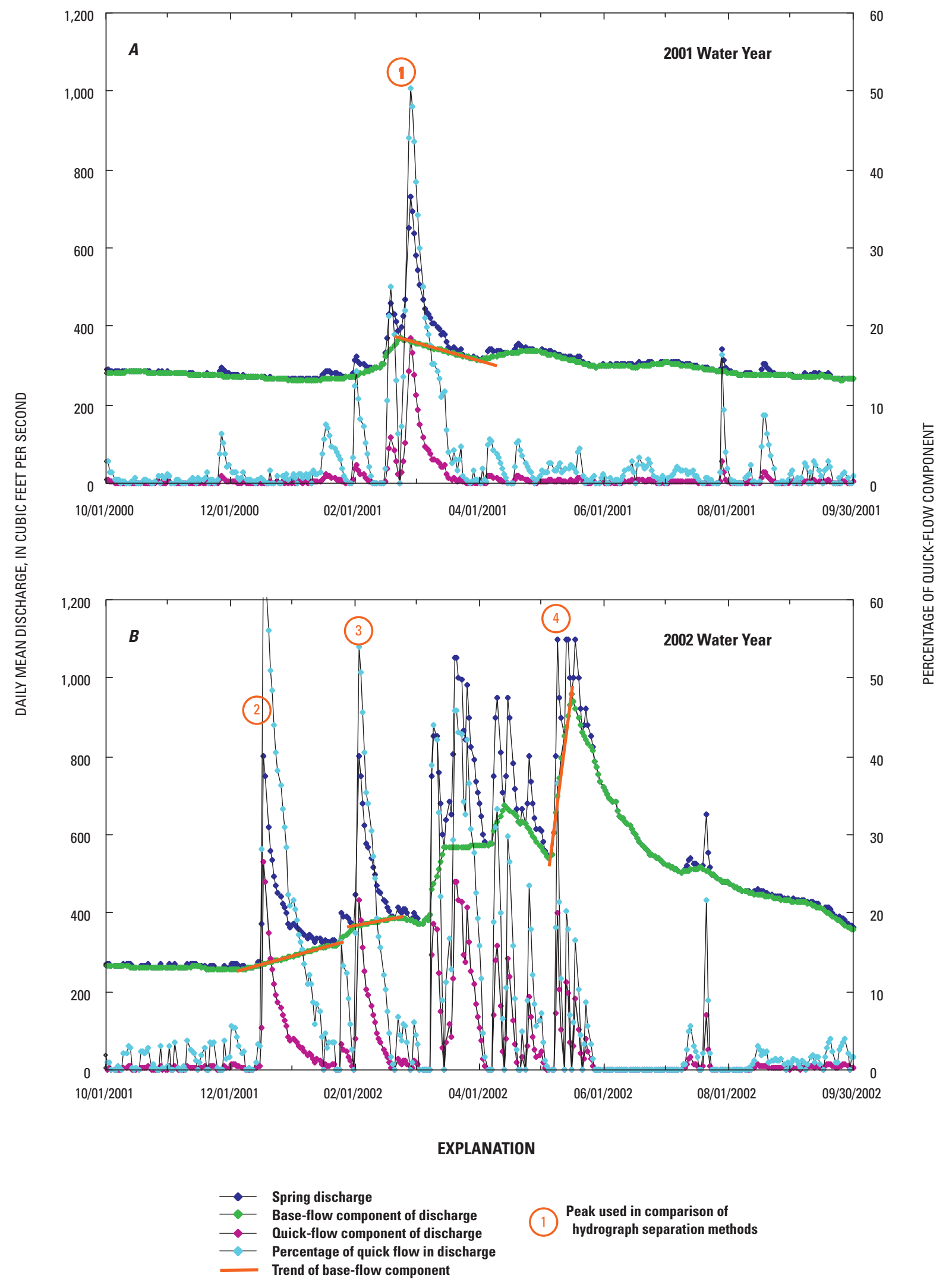

Figure 15. Base-flow and quick-flow components of Big Spring discharge derived using HYSEP hydrograph separation method. 


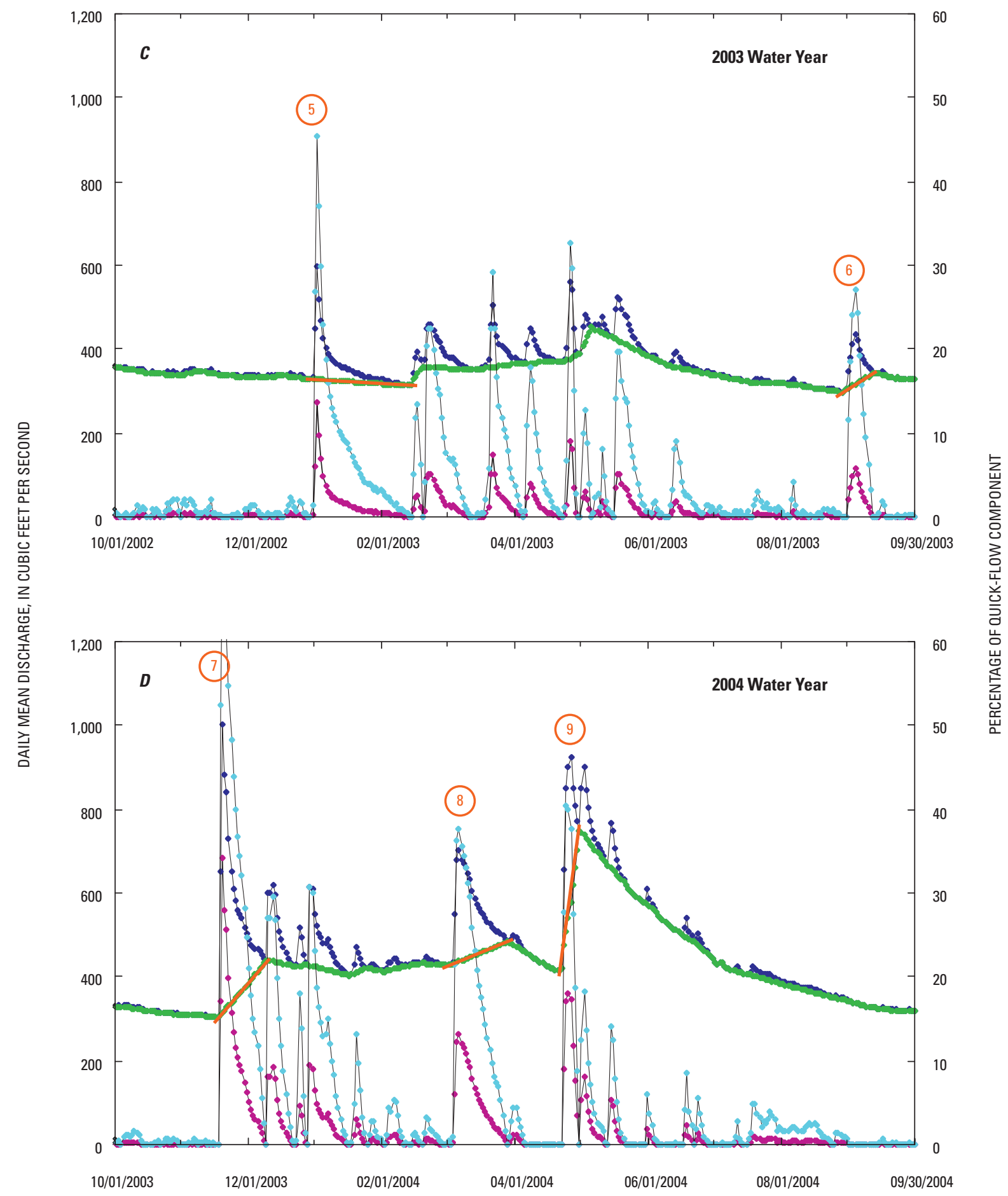

Figure 15. Base-flow and quick-flow components of Big Spring discharge derived using HYSEP hydrograph separation method.-Continued

late February and early March 2001 when rainfall increased spring discharge to more than $700 \mathrm{ft}^{3} / \mathrm{s}$ (fig. 16A; Peak 1). The characteristics of base-flow and quick-flow discharge during this isolated rainfall are more clearly visible than during periods when multiple rainfalls occur before the spring can recover to base-flow conditions. Both base-flow and quickflow discharge components rise abruptly after the rainfall. The increase in base flow is caused by the increased pressure head on the karstic aquifer as infiltrating rainwater fills fractures and voids above the water table. Base flow peaks with the total spring discharge and then declines rapidly. Quick flow also peaks with the total spring discharge, then declines slightly and remains approximately the same for nearly 10 days before declining. Because of the more rapid decrease in base flow 


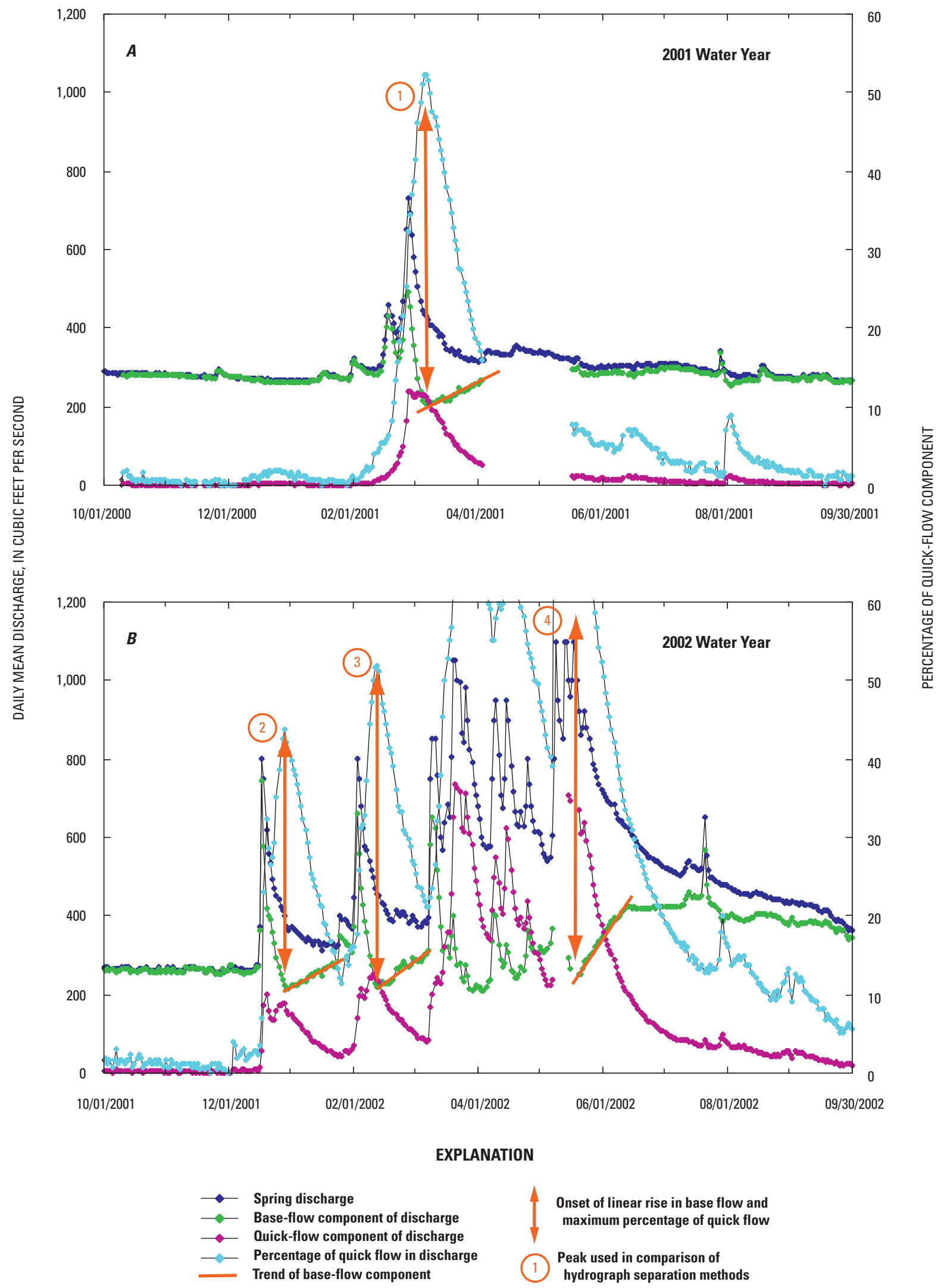

Figure 16. Base-flow and quick-flow components of Big Spring discharge derived using spring discharge and specific conductance data. 


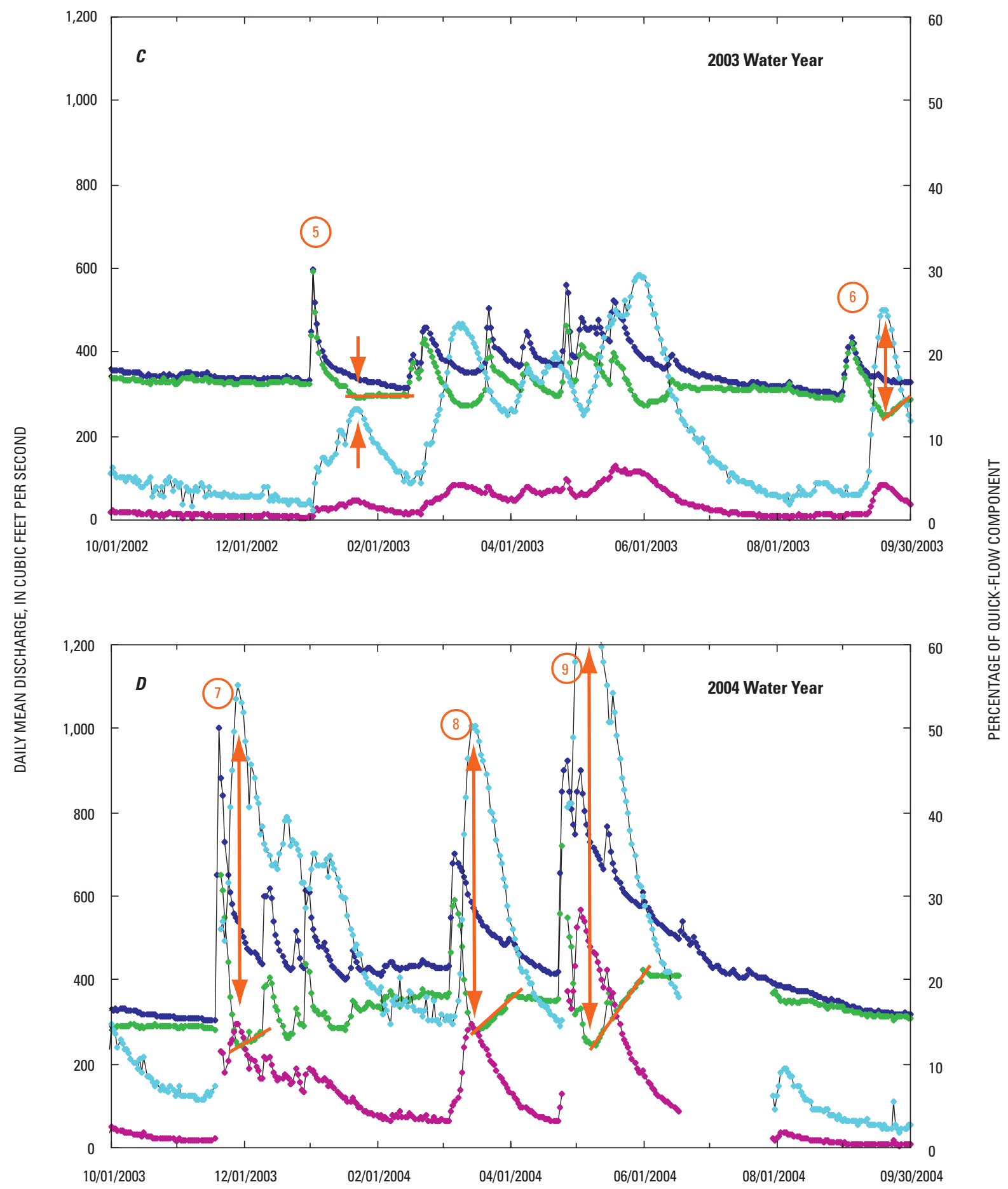

Figure 16. Base-flow and quick-flow components of Big Spring discharge derived using spring discharge and specific conductance data.-Continued

and the lag time before the quick-flow discharge recedes, the percentage of quick-flow discharge peaks at slightly greater than 50 percent of the total spring discharge about 10 days after the hydrograph peak. Spring discharge was much more complex during water year 2002 (fig. 16B) than during water year 2001. Slight hydrograph variation occurred during the fall of 2001 and spring base-flow discharge was nearly constant at approximately $260 \mathrm{ft}^{3} / \mathrm{s}$. The remainder of the water year was characterized by multiple storms in the spring recharge area from December 2001 through May 2002. Although spring discharge reached $800 \mathrm{ft}^{3} / \mathrm{s}$ during December (Peak 2), the percentage of quick-flow discharge did not exceed 50 percent of total discharge. The second major rainfall occurred in early February 2002 (Peak 3) before the spring discharge had recov- 
ered to base-flow levels, and the percentage of quick-flow discharge was slightly more than 50 percent of the total discharge. The more frequent rainfalls from early March to midMay 2002 (Peak 4) caused the quick-flow discharge to peak at more than $600 \mathrm{ft}^{3} / \mathrm{s}$ in March, April, and May and caused the percentage of quick-flow discharge to exceed 60 percent of total discharge for 26 days. This larger quick-flow percentage may also explain the lower Big Spring water temperatures that were observed during this period (fig. 12).

Rainfall in water year 2003 was not sufficient to cause the large spring discharges that were observed in water year 2002. Base flow of less than $400 \mathrm{ft}^{3} / \mathrm{s}$ occurred during much of the year with peak flows between 400 to $600 \mathrm{ft}^{3} / \mathrm{s}$ occurring in the winter and spring of 2003 (fig. 16C). Quick-flow discharge never exceeded $150 \mathrm{ft}^{3} / \mathrm{s}$ during the year and never exceeded 30 percent of the total spring discharge.

Water year 2004 was similar to water year 2002 and was characterized by larger, more-frequent storms that caused spring discharge to exceed $600 \mathrm{ft}^{3} / \mathrm{s}$ in November and December 2003 and March, April, and May 2004 (fig. 16D). Intense rainfall in late April and early May caused the instantaneous quick-flow discharge to briefly exceed $600 \mathrm{ft}^{3} / \mathrm{s}$, even though the calculated daily mean discharge was slightly less than 600 $\mathrm{ft}^{3} / \mathrm{s}$. The percentage of quick-flow discharge exceeded 50 percent in December 2003, March 2004, and May 2004.

The rate of decline of the quick-flow discharge was made for seven rainfall-induced peaks in the spring hydrograph to assess their degree of similarity (fig. 17). A typical but subtle feature of short duration occurs to the base-flow discharge component during these rainfall-induced peaks that is best shown by peak 5 on figure $16 \mathrm{C}$. The base-flow discharge initially peaks, then is followed by a short, approximately stable post-peak discharge that ends immediately prior to the start of the extended period of recession. The normalized quick-flow discharge value was calculated by dividing the quick-flow discharge during the extended period of quick-flow recession by the maximum quick-flow discharge at the beginning of this period of recession. This represents the fraction of quick-flow discharge remaining relative to the discharge at the beginning of the decline. The reference quick-flow discharge at the beginning of the seven periods of decline occurred on March 8 , 2001, December 28, 2001, February 11, 2002, May 23, 2002, June 15, 2003, March 16, 2004, and May 4, 2004. The normalized quick-flow discharge declines at a similar rate for each of the events independently of the nature of the hydrograph before rainfall stopped and spring discharge began to stabilize toward base-flow conditions. The decline trend can be approximated by an exponential decay equation with a decay constant of 0.05 per day. The quick-flow discharge component decays to one-half of its initial value in about 14 days and to one-tenth its initial value in about 46 days. Because it takes so long for the quick-flow discharge to drain from the large area of karstic terrain that supplies ground water to Big Spring, the spring flow rarely declines to base levels during wetter seasons.

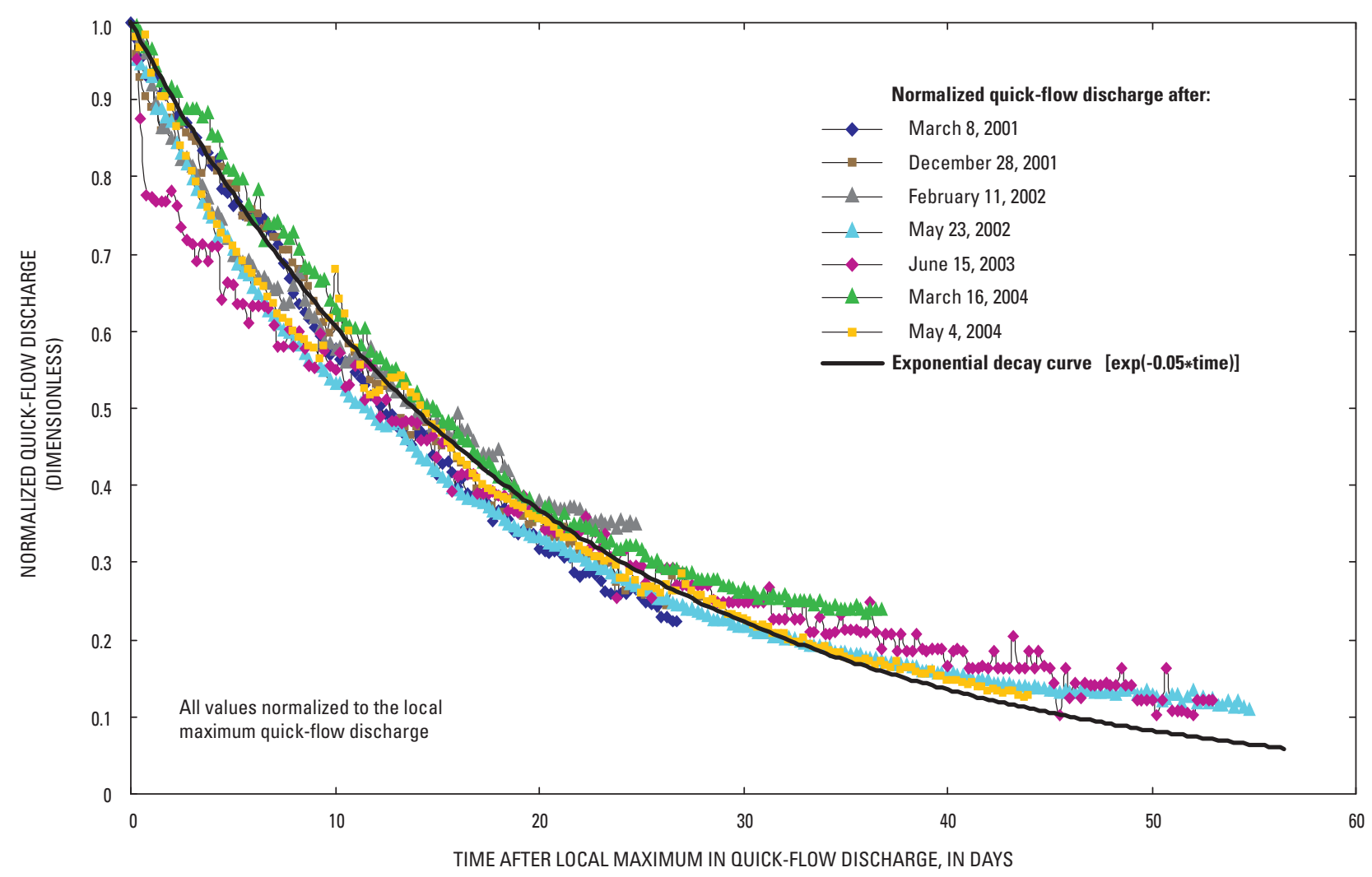

Figure 17. Normalized rate of decline of quick-flow discharge for seven hydrograph events. 


\section{Comparison of Hydrograph Separation Methods}

Daily mean values determined using HYSEP and the discharge and specific conductance hydrograph separation methods were summarized as annual mean values for water years 2001 to 2004 (table 4). Daily mean Big Spring discharge values computed using a stage-discharge relation, and therefore daily mean computed values using the HYSEP method, are available for every day of the 4-year period. Because there were some intervals when specific conductance data were not collected, there are missing data for the discharge and specific conductance method. To make the comparison among the three data sets more meaningful, the analysis includes only days where all three data sets were available. The estimated annual mean quick flow ranged from 15 to $48 \mathrm{ft}^{3} / \mathrm{s}$ for the HYSEP analysis and 26 to $154 \mathrm{ft}^{3} / \mathrm{s}$ for the discharge and specific conductance method. The discharge and specific conductance method consistently estimates a larger percentage of quick flow for each of the 4 water years. The discharge and specific conductance method estimated percentage of quick flow to be most similar to the HYSEP estimated percentage of quick flow in water years 2001 and 2003; although, the estimated percentage of quick flow using the discharge and specific conductance method was 1.8 and 2.1 times larger than the HYSEP estimate in water years 2001 and 2003. The difference between the two methods was even larger for water years 2002 and 2004. The estimated percentage of quick flow using the discharge and specific conductance method was 3.2 and 3.3 times larger than the HYSEP estimates in water years 2002 and 2004. This result occurs because recharge from precipitation in water years 2001 and 2003 was limited to isolated events that caused a moderate rise in the spring hydrograph (2001) or a series of smaller events that caused small rises in the spring hydrograph (2003). In contrast, the spring hydrograph for water years 2002 and 2004 shows evidence of large and frequent recharge events that caused spring flow to be substantial during the winter and spring months.
A more-detailed observation of base-flow and quick-flow component separation for individual hydrograph peaks indicates that the HYSEP method is not as accurate determining these components at Big Spring as the discharge and specific conductance method. During periods characterized by large and abrupt rises in the spring hydrograph, HYSEP invariably calculates a linear change in base flow. At each of nine major or more-isolated hydrograph peaks that occurred during water years 2001 to 2004 (fig. 15), calculated base flow increased linearly or near linearly during the spike in discharge [for example, December 2001 (peak 2), February 2002 (peak 3), May 2002 (peak 4), September 2003 (peak 6), November 2003 (peak 7), March 2004 (peak 8), and April 2004 (peak 9)], or decreased linearly or near linearly during the spike in discharge [for example, February 2001 (peak 1) and January 2003 (peak 5)]. The increasing or decreasing pattern appears to be a function of the length of time from the onset of a substantial rise in the hydrograph to the next recharge-induced rise; the shorter the time between recharge, the greater the slope of the base-flow trend. The local-minimum method of HYSEP checks each day to determine if it is the lowest discharge during a specified time both before and after the day that is being considered. The time that is used is based on the drainage (recharge) area for the site. If that day is the lowest discharge, then it is a local minimum and is connected by straight lines to adjacent local minimums (Sloto and Crouse, 1996). The method can be visualized as connecting the lowest points on the hydrograph with straight lines. Thus, the estimated base flow during periods of high discharge is dictated more by events that follow the hydrograph peak than the peak characteristics.

At each of the nine mentioned hydrograph peaks, the HYSEP-estimated quick flow rose abruptly and peaked on the same day as the discharge hydrograph peak, then declined to near zero within a month. Even during long periods of sustained recharge by frequent storms, the estimated quick flow declined rapidly between storms with no apparent accumula-

Table 4. Summary of base-flow and quick-flow hydrograph-separation methods for Big Spring, 2001-04.

[ $\mathrm{ft}^{3} / \mathrm{s}$, cubic feet per second; \%, percent]

\begin{tabular}{|c|c|c|c|c|c|c|c|c|}
\hline \multirow[b]{3}{*}{$\begin{array}{c}\text { Water } \\
\text { year }\end{array}$} & \multirow{3}{*}{$\begin{array}{c}\text { Big Spring } \\
\text { calculated } \\
\text { annual mean } \\
\text { discharge }^{1} \\
\left(\mathrm{ft}^{3} / \mathbf{s}\right)\end{array}$} & \multirow{3}{*}{$\begin{array}{c}\text { Number of } \\
\text { days in } \\
\text { calculation } \\
\text { of mean } \\
\text { (days) }\end{array}$} & \multicolumn{3}{|c|}{ HYSEP analysis } & \multicolumn{3}{|c|}{ Discharge and specific conductance analysi } \\
\hline & & & \multicolumn{2}{|c|}{ Annual mean } & \multirow[b]{2}{*}{$\begin{array}{c}\text { Quick flow } \\
\text { (\%) }\end{array}$} & \multicolumn{2}{|c|}{ Annual mean } & \multirow[b]{2}{*}{$\begin{array}{c}\text { Quick flow } \\
(\%)\end{array}$} \\
\hline & & & $\begin{array}{c}\text { Base flow } \\
\left(\mathrm{ft}^{3} / \mathrm{s}\right)\end{array}$ & $\begin{array}{c}\text { Quick flow } \\
\left(\mathrm{ft}^{3} / \mathbf{s}\right)\end{array}$ & & $\begin{array}{c}\text { Base flow } \\
\left(\mathrm{ft}^{3} / \mathbf{s}\right)\end{array}$ & $\begin{array}{c}\text { Quick flow } \\
\left(\mathrm{ft}^{3} / \mathrm{s}\right)\end{array}$ & \\
\hline 2001 & 306 & 308 & 291 & 15 & 4.8 & 280 & 26 & 8.4 \\
\hline 2002 & 482 & 355 & 434 & 48 & 9.9 & 328 & 154 & 31.9 \\
\hline 2003 & 363 & 365 & 345 & 18 & 4.9 & 325 & 38 & 10.5 \\
\hline 2004 & 461 & 321 & 424 & 37 & 8.0 & 338 & 123 & 26.7 \\
\hline
\end{tabular}

${ }^{1}$ Annual mean discharge calculated by stage-discharge relation using only days where both discharge and specific conductance data were available. 
tion of quick flow from storm to storm (for example, from March 2002 to June 2002, February 2003 to June 2003, and November 2003 to February 2004). The abrupt decline in quick-flow discharge appears to be inconsistent with quickflow traveltimes ( 8 to 42 days) estimated from dye-trace investigations in the recharge area of Big Spring.

The discharge and specific conductance method of hydrograph separation yields different characteristic curves for the base-flow and quick-flow components. At all nine of the major or more-isolated hydrograph peaks that occurred during water years 2001 to 2004, the estimated base-flow component rises abruptly as the spring hydrograph rises, and attains a peak value on the same day as the discharge peak (fig. 16). The base-flow component declines more abruptly from its peak value than quick flow, then several days later begins to increase at an approximately linear trend until interrupted by a following recharge event [for example, December 2001 (peak 2), February 2002 (peak 3), January 2003 (peak 5), and November 2003 (peak 7)] or until hydraulic conditions change and base flow enters a period of stable to slowly declining flow rates [for example, February 2001 (peak 1), May 2002 (peak 4), September 2003 (peak 6), March 2004 (peak 8), and April 2004 (peak 9)]. The onset of the period of linear rise in base flow approximately coincides with the time at which the percentage of quick flow has reached a maximum after each recharge-induced spring discharge peak (see linear trend lines and marker arrows in fig. 16).

The interval between the spring discharge peak and the peak in percentage quick flow is quite similar for peaks 1 , $2,3,4,7,8$, and 9 . The intervals are 8 to 9 days, 11 days, 11 days, probably 9 days, 9 days, 9 days, and 9 to 10 days for these seven hydrograph peaks. The interval for peak 4 is estimated because specific conductance values were not available during part of that peak. The average interval of about 9.5 days is a similar lag time for each peak, and indicates that large amounts of recharge from the Hurricane Creek Basin in the central part of the recharge area, where dye tracing shows an 8 to 11 day quick-flow traveltime, are arriving at the spring. The interval between the spring discharge peak and the peak in percentage quick flow for two of the mentioned peaks (peaks 5 and 6) are somewhat longer than the others. The interval for peak 5 is 12 to 13 days, and the interval for peak 6 is 15 days. These longer intervals may indicate that more of the rainfall that produced the rise in these discharge hydrographs occurred in the western parts of the large Big Spring recharge area.

To summarize, the incorporation of specific conductance values into the hydrograph separation process for springs yields more reasonable hydrograph separation results than HYSEP, which uses only the shape of the discharge hydrograph. The characteristics of the base-flow and quick-flow components of spring discharge peaks calculated using the discharge and specific conductance method indicate, and are consistent with, the following spring-flow mechanism. The initial recharge of precipitation increases the pressure head on the karstic aquifer and pushes the higher specific conductance values (base flow) stored ground water toward the spring orifice, as seen by the sudden rise in base flow as the discharge hydrograph rises. This occurs because hydraulic pressure can be transmitted through an aquifer much faster than water can flow. Recharging precipitation also drains rapidly into the solution-enlarged fractures and voids of the karst and moves toward the spring orifice. The distribution and intensity of the rainfall, the size and geometry of the karst fracture and conduit system, and the resistance of the flow path (particularly that of its narrowest part) all control the rate at which the quick flow moves through the karst and discharges at the spring. This situation is complicated when the Current River is at a high stage, which inundates the spring with backwater, creates a higher hydraulic head over the spring, and increases the back pressure at the spring. As the quick flow subsides (usually after about 8 to 11 days), the hydraulic head differential between the conduits and the orifice is reduced, and the base flow increases again to a new equilibrium level before beginning the slow decline characteristic of a gravity draining aquifer.

\section{Atmospheric Environmental Tracers in Base Flow and Quick Flow: Estimation of Ground-Water Ages}

In the previous section, discharge from Big Spring was modeled as a mixture of two components-quick flow and base flow. A hydrograph separation model was developed using data on discharge and specific conductance from Big Spring to estimate the fractions of quick flow and base flow in Big Spring discharge. Concentration data of selected environmental tracers [chlorofluorocarbons (CFCs: CFC-11, CFC-12, and CFC-113), sulfur hexafluoride ( $\left.\mathrm{SF}_{6}\right)$, and tritium $\left.\left({ }^{3} \mathrm{H}\right)\right]$ in discharge from Big Spring also were used to test the hydrograph separation model, estimate ages of quick-flow and base-flow components, and estimate mixing fractions.

CFCs are volatile, synthetic compounds of carbon, chlorine, and fluorine that were manufactured for uses in refrigeration, air conditioning, blowing agents in foams and insulation, and in many other industrial and domestic applications. CFC-12 (dichlorodifluoromethane, $\mathrm{CF}_{2} \mathrm{Cl}_{2}$ ) was produced commercially from 1930, and CFC-11 (trichlorofluoromethane, $\mathrm{CFCl}_{3}$ ) was produced from 1936. Many other CFC compounds have since been produced-most notably CFC-113 (trichlorotrifluoroethane, $\mathrm{C}_{2} \mathrm{~F}_{3} \mathrm{Cl}_{3}$ ), produced commercially from 1944 and used primarily by the electronics industry. Release of CFCs to the atmosphere and subsequent incorporation into the hydrologic cycle has closely followed production (Gamlen and others, 1986; Midgley and Fisher, 1993). By the late 1980s, cumulative production of CFC-11, CFC-12, and CFC-113 totaled approximately 7.7, 10.2, and 2.4 million tons (Alternative Fluorocarbons Environmental Acceptability Study, 2006a), and in the northern hemisphere, atmospheric 
concentrations had risen to about 260, 480, and 70 pptv (parts per trillion by volume).

By 2001, atmospheric CFC concentrations were nearly constant or falling because of regulations imposed in 1987 by the Montreal Protocol to Reduce Substances that Deplete the Ozone Layer and subsequent amendments (Alternative Fluorocarbons Environmental Acceptability Study, 2006b; International Atomic Energy Agency, 2006), following recognition that atmospheric CFCs caused depletion of the earth's ozone layer and may contribute to global warming. Most of the samples collected from Big Spring were obtained between 2001 and 2003, when atmospheric concentrations of CFCs were nearly constant (table 5). In 2002, which represents the mid-point of the sample collection period, the average northern hemisphere concentrations of CFC-11, CFC-12, and CFC-113 in air were about 260, 545, and 81 pptv.

Sulfur hexafluoride $\left(\mathrm{SF}_{6}\right)$ is another atmospheric gas that is primarily of anthropogenic origin, but also occurs naturally in some rocks (Harnisch and Eisenhauer, 1998; Busenberg and Plummer, 2000). $\mathrm{SF}_{6}$ is mainly used as an electrical insulator in high voltage switches and transformers. The concentration of $\mathrm{SF}_{6}$ in the troposphere has increased from a steady-state value of 0.054 plus or minus 0.009 to about 6 pptv during the past 45 years (Busenberg and Plummer, 1997; 2000). The atmospheric history of $\mathrm{SF}_{6}$ is now well established (Maiss and Levin, 1994; Maiss and Brenninkmeijer, 1998; U.S. Geological Survey, 2006a) and the mixing fraction of $\mathrm{SF}_{6}$ is currently (2007) increasing at a rate of about 6 percent per year while those of the CFCs are nearly constant or decreasing. North American air contained about 5.1 pptv of $\mathrm{SF}_{6}$ in 2002 (table 5).

Tritium, the radioactive isotope of hydrogen (half-life of 12.32 years; Lucas and Unterweger, 2000), is the most commonly used environmental tracer to indicate the presence of modern recharge. Environmental tritium is formed naturally in the upper atmosphere from the bombardment of nitrogen by the flux of neutrons in cosmic radiation and in the recent past from atmospheric testing of nuclear weapons. Since 1952, the source from atmospheric tests of nuclear weapons overwhelmed the natural source and, therefore, the ${ }^{3} \mathrm{H}$ concentration in precipitation is represented by a series of pulses with the largest pulse occurring during 1963 and 1964. The shape of the ${ }^{3} \mathrm{H}$ pulse differs substantially from the relatively smooth concentration functions for $\mathrm{CFCs}_{\text {and }} \mathrm{SF}_{6}$. Because of various meteorological processes and atmospheric moisture sources (Rozanski and others, 1991), a local record of tritium in precipitation for a particular region being studied generally needs to be constructed. Several scaling procedures exist for reconstruction of local ${ }^{3} \mathrm{H}$ records on the basis of records from parts of North America (Michel, 1989, 2005). In 2002, precipitation in the study area averaged about 7.2 TU (tritium units). The concentration functions of $\mathrm{CFCs}, \mathrm{SF}_{6}$, and ${ }^{3} \mathrm{H}$ used to interpret the spring data are shown in figure 18.

Ground-water dating and environmental tracer applications with $\mathrm{CFCs}$ and $\mathrm{SF}_{6}$ are possible because (1) the history of the atmospheric concentrations is known or has been reconstructed from production/release data; (2) the Henry's Law solubilities of these tracers in water are known as a function of temperature, pressure, and salinity; and (3) instrumentation and analytical procedures are available to measure the concentrations of $\mathrm{CFCs}_{\text {and }} \mathrm{SF}_{6}$ in air and water (Busenberg and Plummer, 1992, 2000). Following recharge and isolation from the atmosphere, ground waters generally are unaffected by gas exchange processes because gas diffusion coefficients in water are approximately five orders of magnitude smaller than in air. Because the shape of the tritium concentration function differs substantially from that of $\mathrm{CFCs}_{\text {and }} \mathrm{SF}_{6}$ (fig. 18), the combined use of $\mathrm{CFC}$ or $\mathrm{SF}_{6}$ with tritium can provide considerable information that is of value in interpreting ground-water mixing and ages of young and old fractions in mixtures.

\section{Collection of Water Samples}

Ground water issuing from Big Spring was sampled with a stainless steel, nitrogen-operated, submersible piston pump at a low-flow rate to minimize loss of $\mathrm{CFCs}$ and $\mathrm{SF}_{6}$ and contamination from unsuitable pump-construction materials in the sample. The pump discharge line was made of refrigeration-grade copper tubing to avoid contamination from plastic materials. The CFC samples were fused into borosilicate glass ampoules with a ultra-pure nitrogen headspace. The $\mathrm{SF}_{6}$ samples were collected in 2-liter glass bottles with polycone seal caps without headspace. The samples were analyzed at the USGS Chlorofluorocarbon Laboratory in Reston, Virginia. Samples for tritium determination were collected in 1-liter plastic bottles and analyzed at the USGS Low-Level Tritium

Table 5. Atmospheric concentrations of CFC-11, CFC-12, CFC-113, SF ${ }_{6}$ and ${ }^{3} \mathrm{H}$ in precipitation in southern Missouri, $2001-03$.

[pptv, parts per trillion by volume; TU, tritium units; --, no data]

\begin{tabular}{|c|c|c|c|c|c|}
\hline Year & $\begin{array}{l}\text { CFC-11 } \\
\left(p p t v^{1}\right)\end{array}$ & $\begin{array}{l}\text { CFC-12 } \\
\left(p p t v^{1}\right)\end{array}$ & $\begin{array}{c}\text { CFC-113 } \\
\left(p p t v^{1}\right)\end{array}$ & $\begin{array}{c}S F_{6} \\
\left(p p t v^{1}\right)\end{array}$ & $\begin{array}{c}{ }^{3} \mathrm{H} \\
\left(\mathrm{TU}^{2}\right)\end{array}$ \\
\hline 2001 & 262 & 547 & 82 & 4.9 & 6 \\
\hline 2002 & 260 & 545 & 81 & 5.1 & 7 \\
\hline 2003 & 258 & 543 & 80 & 5.3 & -- \\
\hline
\end{tabular}

${ }^{1}$ http://water.usgs.gov/lab.

${ }^{2}$ R.L. Michel, U.S. Geological Survey, Menlo Park, Calif., written communication, 2006. 


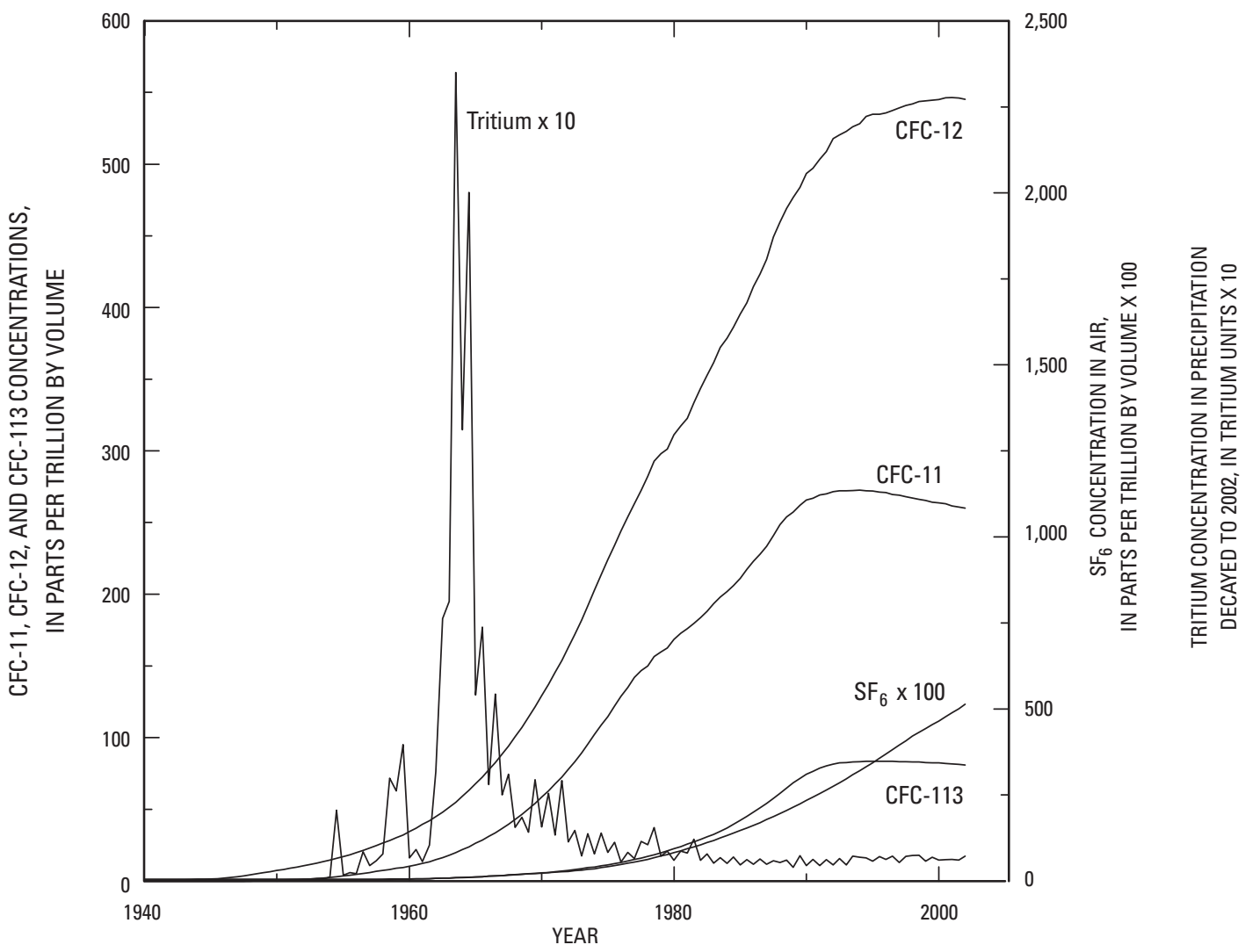

Figure 18. Concentrations of chlorofluorocarbons (CFC-11, CFC-12, and CFC-113) and sulfur hexafluoride $\left(\mathrm{SF}_{6}\right)$ in North American air and tritium in precipitation in Missouri decayed to 2002, 1940 to 2002.

Laboratory in Menlo Park, California, by electrolytic enrichment and liquid scintillation counting. Details of the sample collection procedure are described in U.S. Geological Survey (2006b), along with information on methods of laboratory analysis. CFCs are routinely detected at the USGS Chlorofluorocarbon Laboratory in water at concentrations greater than 0.3 to $1.0 \mathrm{pg} / \mathrm{kg}$ (picogram per kilogram of water). The detection of CFC-12 indicates post-1945 recharge or older water samples that contain a fraction of post-1945 water. Similarly, detection of CFC-11 and CFC-113 indicates post-1950 and post1957 water, or their mixtures. The detection of $\mathrm{SF}_{6}$ generally indicates post-1970 water or mixtures containing a fraction of post-1970 water.

Concentrations of $\mathrm{CFCs}, \mathrm{SF}_{6}$, and ${ }^{3} \mathrm{H}$ in recharging meteoric water are assumed to be consistent with air-water equilibrium at the time of infiltration or of the concentration of tritium in local precipitation at the time of recharge. The concentrations of atmospheric gases in recharge depend on temperature of recharge, altitude of recharge (barometric pressure), and entrapment of excess air in pore spaces above the water table that is forced downward during recharge.

Measurements of the concentrations of dissolved nitrogen $\left(\mathrm{N}_{2}\right)$ and argon (Ar) in the water samples permits determination of recharge temperature and excess air (U.S. Geological Survey, 2006b). The altitude of recharge was assumed to be that of the altitude of the water table in the catchment area of Big
Spring. Because the water in Big Spring remains aerobic, no potential for degradation of CFCs exists in the ground-water environment, or of denitrification. However, some of the water samples may contain an excess of $\mathrm{SF}_{6}$ from terrigenic sources. Although depth to ground water in the mature karst recharge area of Big Spring can range from a few feet to more than 400 $\mathrm{ft}$, air probably moves freely through the larger fractures and conduits of the mature karst, so that infiltration water remains in contact with modern air during recharge even through deep unsaturated zones. As a result, the CFC "age" remains modern until sufficient recharge occurs isolating the water sample from the unsaturated zone air. In karst environments such as Big Spring, the next storm probably provides sufficient recharge to isolate the sample from gas exchange with the unsaturated zone air.

By measuring concentrations of the $\mathrm{CFCs}$ and $\mathrm{SF}_{6}$ in ground water and by estimating the temperature, altitude of recharge, and excess air, the partial pressures of the gases in the water sample can be calculated in parts per trillion by volume. The estimated parts per trillion by volume concentrations are then compared with historic measured atmospheric data to estimate the apparent age of the ground water (Busenberg and Plummer, 1992; Cook and Solomon, 1995; Plummer and Busenberg, 1999; Busenberg and Plummer, 2000). The apparent age applies only to unmixed water samples. However, different aquifer flow regimes can cause ground-water samples 
collected from wells or springs to be a mixture of water of different ages. Consequently, these tracers can be used to assess the mixing of water of different ages in discharge from Big Spring.

\section{Interpretation of Mixing and Water Ages using Environmental Tracer Data}

The environmental tracer data collected as a part of this study are summarized in tables 6,7 , and 8 (at the back of this report) along with selected calculated results. Dissolved $\mathrm{N}_{2}$ and Ar data along with the calculated recharge temperature and quantity of excess air are listed in table 6 . The measured concentrations of CFCs in ground water from Big Spring and Greer Spring are summarized in table 7. The concentrations in table 7 are calculated from Henry's Law at the recharge temperature given in table 6 and reported in parts per trillion by volume. The corrections of the measured CFC values for excess air were small. Two sets of CFC ages are given in table 7. The first is the apparent, piston-flow age, calculated assuming an unmixed sample. The second is the age of the young fraction calculated using a binary mixing model that assumes that the young fraction is mixed (diluted) with old, pre-tracer water. The percentage of young water is calculated for the binary mixing model according to guidelines provided by the International Atomic Energy Agency (2006). As shown in table 7, neither of these models yield useful age information for discharge from Big Spring, but are given for reference purposes. The $\mathrm{SF}_{6}$ data are summarized in table 8, giving the measured concentration, and the parts per trillion by volume concentration calculated at the recharge temperature and corrected for excess air (table 6). Because of the extremely low solubility of $\mathrm{SF}_{6}$ in water, the excess air correction is substantial for $\mathrm{SF}_{6}$. The apparent piston-flow age for $\mathrm{SF}_{6}$, for reference purposes, and the available tritium concentrations are listed in table 8.

Assignment of an age to a ground-water sample depends on the model used to interpret the age; that is, all ground-water ages are model dependent. Several models were used to make preliminary age estimates with the $\mathrm{CFC}$ and $\mathrm{SF}_{6}$ data in tables 7 and 8 . The first model (piston-flow) assumes the samples are unmixed, as if recharge water flows through a pipe from point of recharge to discharge at Big Spring. Using the piston-flow model, CFC ages range from 13 to 31,1 to 30 , and 10 to 24 years for CFC-11, CFC-12, and CFC-113, (table 7). The binary mixing model results shown in table 7 assume mixing of a young component water with old tracer free water. The implied ages of the young fraction in this case (based on the CFC-113/CFC-11 ratio) range from 5 to 16 years with calculated mixing fractions of 31 to 99 percent young water (table 7). The $\mathrm{SF}_{6}$ piston flow apparent ages range from 9 to 21 years (table 8). The ages calculated from both models are all inconsistent with some of the physical and hydrogeologic observations at Big Spring because of the complexities of ground-water flow in karst areas, and are, therefore, invalid.
The first contradiction with the hydrogeologic data comes from the dye traces (discussed earlier) indicating traveltimes of first arrival of some fraction of discharge at Big Spring on the order of a few tens of days, followed by an attenuation of the dye pulse lasting over a period of at least several months. Because the dye traces have a relatively short traveltime to Big Spring does not mean that all the water discharging at Big Spring has ages of tens of days, but instead, discharge contains a component of fresh meteoric water that presumably is mixed with somewhat older stored ground water. Those fractions correspond with the quick-flow and base-flow components of the hydrograph. Based on the discharge and specific conductance hydrograph separation analysis, the fraction of quick flow varied from about 2 to 45 percent on the days environmental tracer samples were collected. The binary mixing model results would be consistent with the hydrograph separation results only if the quick-flow component had ages on the order of tens of years (table 7). This seems unlikely based on traveltimes from dye traces, but additional data are needed to resolve the question of the age of the quick-flow and base-flow components.

\section{Age of the Quick-Flow and Base-Flow Components at Big Spring Inferred from Tracer Concentrations as a Function of Percentage Quick Flow}

During this study, measured discharge made in conjunction with isotope sampling at Big Spring ranged from about 275 to $525 \mathrm{ft}^{3} / \mathrm{s}$, with one maximum discharge of $800 \mathrm{ft}^{3} / \mathrm{s}$. Most of the values of percentage quick flow, calculated using the discharge and specific conductance method, vary linearly with spring discharge (fig. 19). The concentrations of CFC-11, CFC-12, CFC-113, and $\mathrm{SF}_{6}$ (in parts per trillion by volume) in discharge from Big Spring are plotted as a function of percent quick flow in figure 20. For quick-flow components ranging from about 5 to 45 percent of discharge, the $\mathrm{CFC}$ and $\mathrm{SF}_{6}$ concentrations vary approximately linearly with percent quick flow. The highest calculated percentage of quick flow was 45 percent. Extrapolation of the linear relation between tracer concentration in spring discharge and percentage quick flow to 100 percent quick flow implies $\mathrm{CFC}$ and $\mathrm{SF}_{6}$ concentrations nearly identical to those in the 2002 atmosphere (table 5). This indicates most samples containing more than 5 percent quick flow have tracer concentrations consistent with dilution of modern water that was determined from the discharge and specific conductance analysis. The CFC concentration functions for air have been nearly constant for the past decade (fig. 18); therefore, a modern age based on CFCs applies to an age range of recharge from the early 1990s to the date of sample collection. In comparison, $\mathrm{SF}_{6}$ has increased steadily and indicates a modern age for the quick-flow component that is resolved approximately within 1 year. At the other extreme, extrapolating the linear relation of $\mathrm{CFC}$ and $\mathrm{SF}_{6}$ concentration from the modern air value (dot on the ordinate of figure 20) to zero 


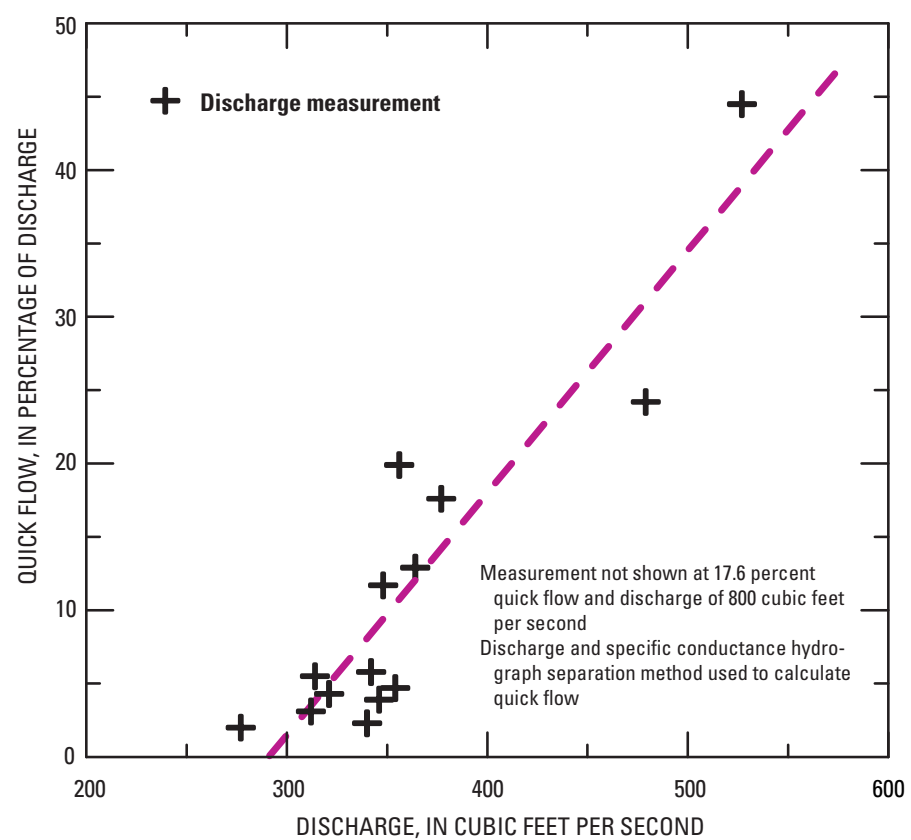

Figure 19. Discharge from Big Spring as a function of percentage quick flow, water years 2001-04.

percent quick flow implies concentrations of approximately 100 (90-105), 238 (220-250), 29 (20-35), and $1.4(1.2-1.9)$ pptv for CFC-11, CFC-12, CFC-113, and $\mathrm{SF}_{6}$ in the base-flow component, if discharge from Big Spring were a mixture of two components-modern water and an older component containing fixed constant tracer concentrations. The extrapolated tracer concentrations to zero percent quick flow imply baseflow (piston flow) recharge dates of about 1976 (1975-1977), 1974 (1973-1974), 1982 (1979-1983), and 1985 (1983-1988) based on CFC-12, CFC-11, CFC-113, and $\mathrm{SF}_{6}$ values. The difference in implied base-flow ages from the various tracers may indicate some concerns in the tracer systematics, but more likely indicate that the mixing scenario, while correctly identifying the quick-flow component as modern, does not adequately describe the age of the older base-flow water. As percent quick flow decreases to less than about 5 percent (between 5 and 2 percent quick flow), the tracer concentrations, particularly those of CFC-12 and CFC-11, decrease substantially less than the values extrapolated to zero percent quick flow (fig. 20). For example, if a line is drawn between modern CFC-12 and the lowest concentration measured (fig. 20), none of the other CFC-12 observations lie along the dilution line (fig. 20). This indicates that, while the old component was nearly constant in composition in mixtures containing more than about 5 percent quick flow, the reservoir of older water in the Big Spring watershed may be a series of water mixtures with piston-flow ages greater than those obtained by extrapolation to zero percent quick flow. Each sample point with a low percentage of quick flow (less than 5 percent) may be a unique mixture. By assuming a mixing model more complex than the binary model, the age of the old fraction can be estimated.

\section{Tracer Relations among CFC-11, CFC-113, and $\mathrm{SF}_{6}$-Mean Age of Base Flow}

Tracer-tracer plots provide a useful tool for examining more complex mixtures in ground water. Two such tracertracer plots are shown in figures $21\left(\mathrm{CFC}-11\right.$ and $\mathrm{SF}_{6}$ concentrations) and 22 (CFC-113 and $\mathrm{SF}_{6}$ concentrations). The lines on the figures represent several age/mixing models. The solid black line represents unmixed, piston-flow samples with the plus signs corresponding to water recharge dates along the piston-flow line. The straight dashed purple line, extending from the year 2002 to 0 concentration, represents the simple binary mixing of modern and old, tracer-free water. Results from two more-complex mixing models (exponential mixing and exponential-piston flow mixtures-the latter assuming a piston flow to exponential ratio of 1) are shown as dashed blue and dashed turquoise lines. The exponential model applies to a well-mixed reservoir or, in the case of a spring, an average of the ages of all the flow lines discharging from the spring. Further details of exponential and exponential-piston flow mixing can be found in Cook and Böhlke (1999).

The young component of quick flow is modern (fig. 20), so lines can be drawn from the modern point (upper right hand corner on figs. 21 and 22) through each sample point to the intersection with another model line to estimate the age of the old, base-flow component. The orange dots on figures 21 and 22 represent tracer-concentration measurements from Big Spring and the point labels give the percentage quick flow calculated from the hydrograph separation technique. If the ages of the base-flow water were described by piston flow, the apparent recharge dates of the base-flow component would decrease from about 1974 (45 percent quick flow) to about 1960 (2 percent quick flow) based on CFC-11 and $\mathrm{SF}_{6}$ data (fig. 21).

Although the actual mixing model for the base-flow component is uncertain, the data of figure 20 indicate that the baseflow component contains low concentrations of the measured environmental tracers, indicating relatively old age. Further, the base-flow component is likely a mixture because the piston-flow apparent ages differ among the various tracers in the base-flow component. If base-flow waters were unmixed, the piston-flow ages would agree between the various tracers; however, they do not. The lowest concentrations of CFC -11 , CFC-12, and CFC-113 at low percentage quick flow (fig. 20) correspond to piston flow apparent ages of 1972, 1972, and 1979. Agreement in piston-flow CFC-11 and CFC-12 apparent ages and young CFC-113 apparent age is characteristic of binary mixing of young and old (pre-tracer) water, although other mixing models could also result in this observation.

Although the precise mixing model for the base-flow component is uncertain, the exponential model can be applied to the tracer data from Big Spring to infer ranges of mean ages of water in the base-flow component. As the percentage of quick-flow water decreases to less than about 5 percent, the apparent age of the base-flow component decreases (fig. 20). Each storm would result in a small fraction of mixing of the 

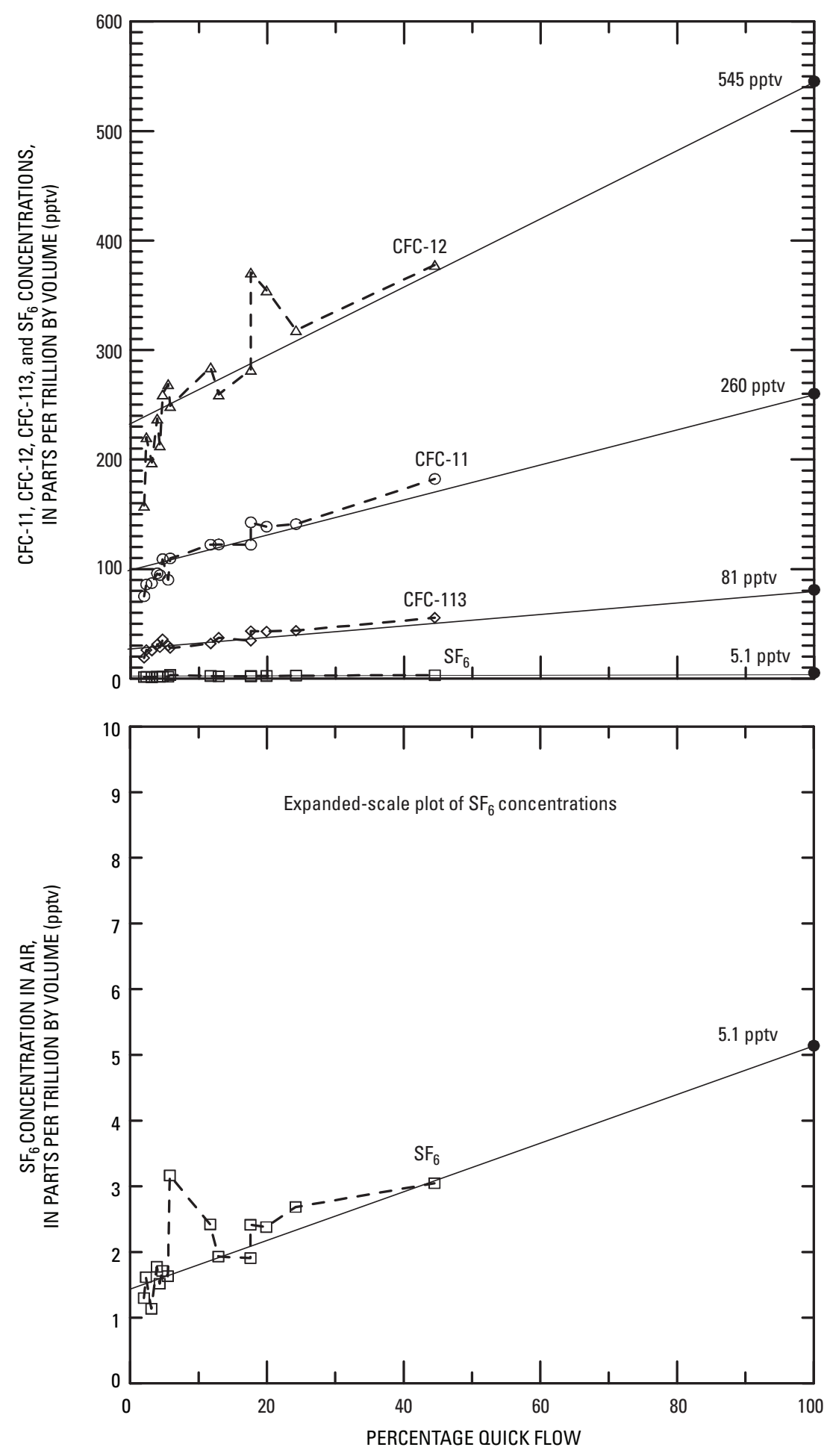

EXPLANATION

5.1 pptv Extrapolation of linear relation between tracer concentration in spring discharge and percentage of quick flow to 100 percent quick flow

Figure 20. Concentrations of chlorofluorocarbons (CFC-11, CFC-12, and CFC-113) and sulfur hexafluoride $\left(\mathrm{SF}_{6}\right)$ in discharge from Big Spring as a function of percentage quick flow. young component with the base-flow component. The environmental tracer data from Big Spring plot intermediate to the simple binary mixing of modern and old, pre-tracer water and results from the exponential mixture model (figs. 21 and 22). Based on the observation of short traveltimes of dye traces that discharged at Big Spring, the discharge contains fractions of modern water mixed with older water. Three binary mixing lines (dashed orange lines on figs. 21 and 22) were drawn from the modern water (2002) component, through the measured tracer concentration points, and projected to the exponential model to indicate mean ages of waters in the base-flow component. These binary mixing lines encompass most of the CFC-11, CFC-113, and $\mathrm{SF}_{6}$ data and indicate mean ages of water in the base-flow component ranging from approximately 30 to 200 years. The mean age of the base-flow component is youngest (approximately 30 to 40 years) in samples containing the highest quick-flow component (45 percent quick flow) and increases to 200 years or more as the fraction of quick flow decreases to less than 5 percent (figs. 21 and 22). This is a further indication that base flow is part of a continuum of older water of varying average ages. One sample from Big Spring plots outside the model boundaries on both figures (figs. 21 and 22) and may contain an excess of $\mathrm{SF}_{6}$ from terragenic sources. The samples from Greer Spring appear to be mostly dilutions of modern water with old, pre-tracer water.

\section{Tracer Relations among CFC-11, CFC-12, and $\mathrm{SF}_{6}$ - Mean Age of Base Flow}

The tracer-tracer plots (figs. 21 and 22) indicate generally concordant results among the data for CFC-11, CFC-113, and $\mathrm{SF}_{6}$. These data also are concordant with the few tritium measurements that were available (discussed in following tritium section). However, the CFC-12 data do not conform as well when used with the other tracer data. Inspection of the CFC-12 data in relation to the other tracers indicates local enrichment of CFC-12 of as much as 25 percent relative to CFC-11 in North American air (fig. 23). Unfortunately, the concentrations of CFCs in local air were 


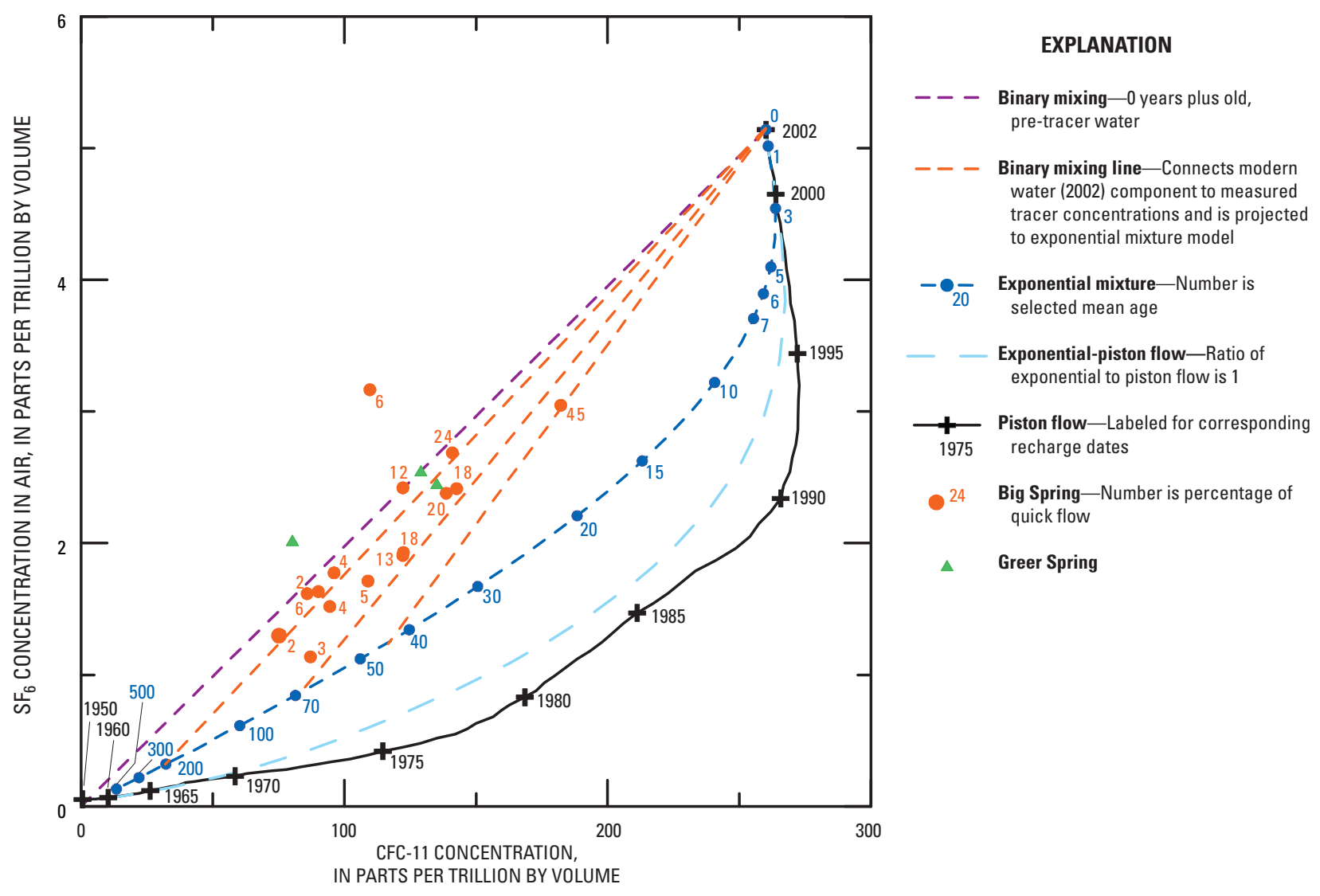

Figure 21. Concentrations of chlorofluorocarbon (CFC-11) and sulfur hexafluoride $\left(\mathrm{SF}_{6}\right)$ in discharge from Big Spring and Greer Spring in relation to several possible mixing models.

not measured during this investigation. In previous studies, observations similar to those of figure 23 have been interpreted as degradation of $\mathrm{CFC}-11$ relative to $\mathrm{CFC}-12$ in soils during infiltration (Plummer and others, 2001; International Atomic Energy Agency, 2006). However, because of the general concordance of CFC-11 with all the other environmental tracer data, CFC-11 degradation was not expected. Apparently, recharge from storms passes fairly rapidly to the water table in this karstic environment. Only the CFC-12 data seem elevated. The extrapolation of $\mathrm{CFC}-12$ concentrations as a function of percent quick flow in figure 20 to 100 percent quick flow, though they may be consistent with the composition of modern air, is poorly constrained at quick-flow fractions greater than 45 percent. This conclusion becomes apparent when the CFC-12 data are compared to CFC-11 (fig. 23). Even though the Big Spring waters appear elevated in CFC-12, the CFC-12 results generally are still concordant with the mixing relations indicated by the CFC-11, CFC-113, and $\mathrm{SF}_{6}$ data. When CFC-12 concentrations are plotted with $\mathrm{SF}_{6}$ concentration data (fig. 24), none of the samples plot along the binary dilution of modern and old (pre-tracer) water, but instead are shifted to somewhat elevated $\mathrm{CFC}-12$ concentrations and approach the model line for exponential mixing (blue line on fig. 24). Though these results differ somewhat from other tracer-tracer results, they still are consistent with the model of dilution of modern water (year 2002) with old water, and if the age distribution in the base flow can be modeled by exponential mixing, mean ages of approximately 20 years, increasing to approximately 200 years, with generally decreasing fraction of quick flow are implied (fig. 24).

\section{Inference of Base-Flow Age from Tritium Analysis}

Only six samples of tritium were collected. Three samples were from Big Spring, with percent quick-flow values of 2, 18, and 45 percent, and three samples were from Greer Spring. These tritium values are shown in relation to CFC-11, CFC-113, and $\mathrm{SF}_{6}$ in figure 25. All three plots are consistent with a mixing model of a modern component with an old component that does not contain tritium (pre-tracer). All three plots extrapolate to extremely low tritium values and indicate that the old fraction is mostly pre-1960s in age, and, if an exponential mixture occurs (dashed dark blue line on figure 25), the mean residence time would be more than several hundred years to be consistent with the measured tritium values. The one sample from Big Spring with 45 percent quick flow had a tritium concentration nearly one-half that of modern precipitation, consistent with the binary mixing sce- 


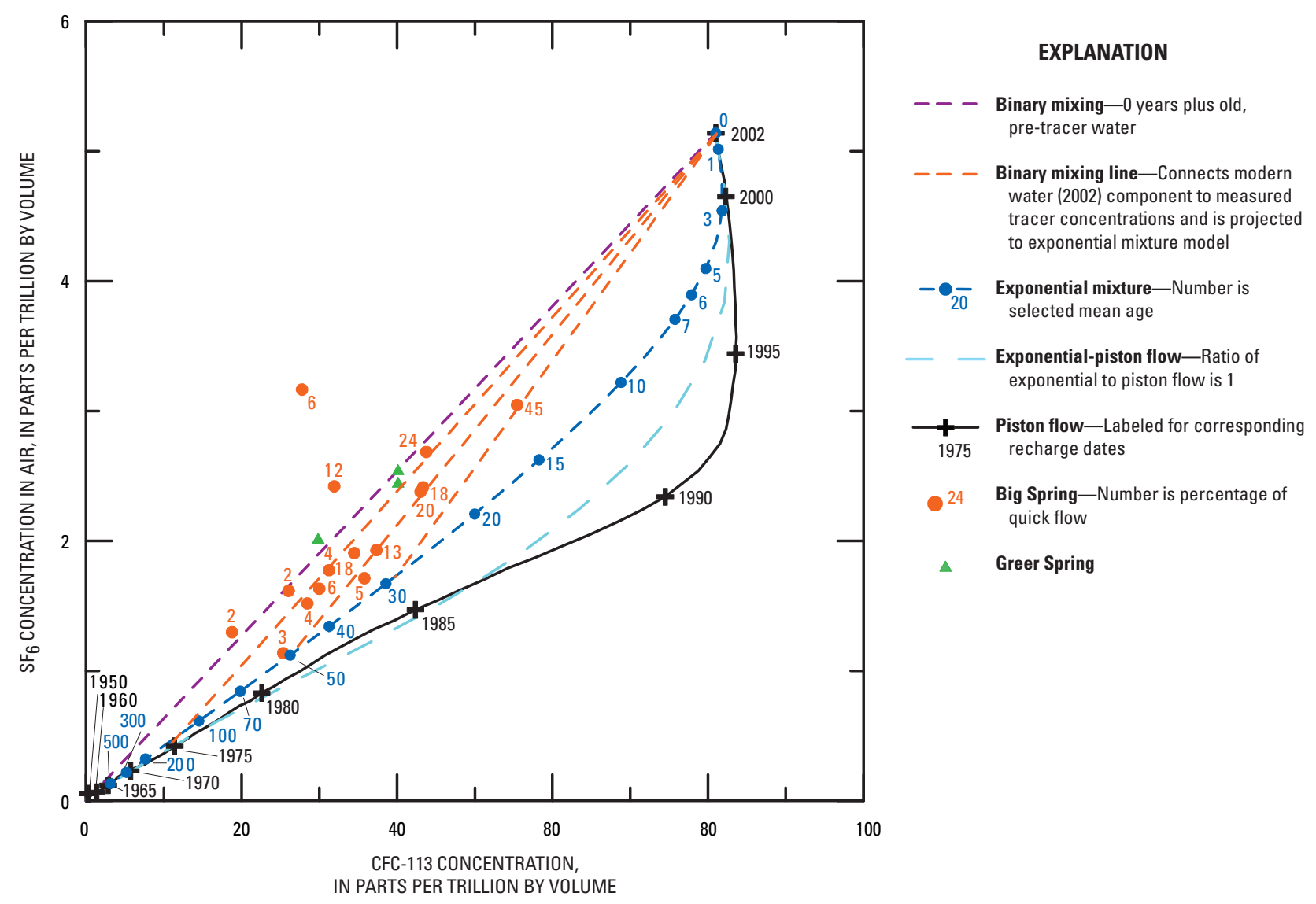

Figure 22. Concentrations of chlorofluorocarbon (CFC-113) and sulfur hexafluoride $\left(\mathrm{SF}_{6}\right)$ in discharge from Big Spring and Greer Spring in relation to several possible mixing models.

nario. Although the data point for 45 percent quick flow plots slightly below the binary mixing lines in figure 25 , the slope of the binary mixing line is expected to vary somewhat with seasonal variations in the tritium content of precipitation. The available tritium data are consistent with the previous observations obtained from CFC-11, CFC-113, and $\mathrm{SF}_{6}$. If the old fraction of discharge from Big Spring contained water from the mid-1960s, elevated tritium concentrations (fig. 18) would be detected in samples with a low percent quick flow. Instead, a decrease in tritium concentration occurs as percentage quick flow decreases (and fraction of baseflow increases; fig. 25). Therefore, the tritium data, in combination with the CFC and $\mathrm{SF}_{6}$ data indicate a mostly pre-nuclear weapons testing age in the base-flow component of the water.

\section{Inference of Base-Flow Age by Hydrograph Separation and Environmental Tracers}

Equations 1 to 4 permitted calculation of the percentage of base flow and quick flow in spring discharge. The extreme specific conductance values (quick flow $100 \mu \mathrm{S} / \mathrm{cm}$ and base flow $357 \mu \mathrm{S} / \mathrm{cm}$ ) used in the calculations of the quick-flow and base-flow components were determined from field observations or personal communication with technicians and were assumed constant with time. This was a reasonable assumption from thermodynamic considerations; the composition of the base-flow component should approach a nearly constant composition as water-rock reactions proceed toward equilibrium. That is, as the age of the base-flow component increases, the specific conductance of the base-flow component $(\mathrm{Cb}$ value of $357 \mu \mathrm{S} / \mathrm{cm}$ ) is assumed to approach a constant value. In general, the application of equations 1 to 4 to discharge would not be as reliable using concentrations of environmental tracers to obtain estimates of percent quick flow, unless it can be demonstrated that the ages of both flow components were constant. Still, there are advantages and limitations to using equations 1 to 4 with specific conductance and/or with environmental tracer data, both in conjunction with discharge data.

By solving equations 1 to 4 using transient environmental tracer data (CFCs, $\mathrm{SF}_{6}$, and tritium), information can be obtained about the concentration of an environmental tracer in the base-flow component. That information can then be used through an appropriate mixing model to obtain information on the age of the base-flow component. Using the calculated values of percent quick flow (based on the discharge and specific conductance method), the calculated concentrations of CFC-11, CFC-12, and CFC-113 in the base-flow component for Big Spring are given in figure 26 ( $\mathrm{SF}_{6}$ not shown). 


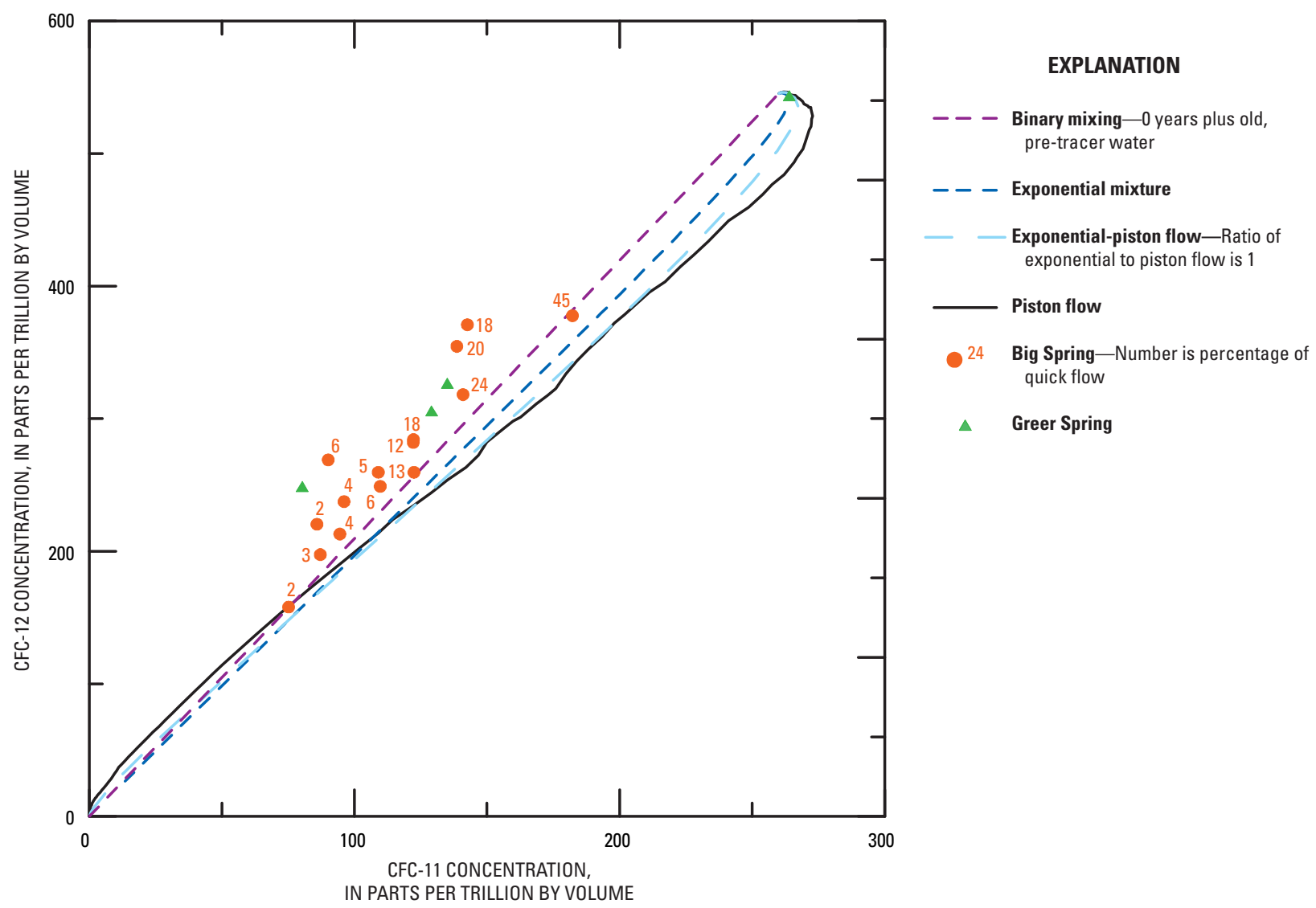

Figure 23. Concentrations of chlorofluorocarbons (CFC-11 and CFC-12) in discharge from Big Spring and Greer Spring in relation to several possible mixing models

The median concentrations of CFC $-11, \mathrm{CFC}-12, \mathrm{CFC}-113$, and $\mathrm{SF}_{6}$ in base flow were 100.9, 237, 28.1, and 1.4 pptv. The age of the base-flow component depends on the model used to interpret age. If piston flow is assumed, the median concentrations in base flow correspond to apparent recharge dates of 1974, 1976, 1982, and 1985, for CFC-11, CFC-12, CFC-113, and $\mathrm{SF}_{6}$. As discussed previously, the piston-flow model is unlikely to be applied to base flow from Big Spring. The calculated CFC concentrations of the base-flow component are nearly constant when percent quick flow is greater than about 5 percent of spring discharge, but decreases as percent quick flow decreases to less than 5 percent, implying older ages in the highest fraction of base flow (fig. 26). If the exponential model applies, the calculated base-flow concentrations indicate mean ages of 40 to more than 200 years. Apparently, some age stratification is present in the older resident water in the Ozark aquifer discharging to Big Spring.

\section{Recharge Temperatures and Water Temperatures}

The calculated recharge temperature determined from dissolved $\mathrm{N}_{2}$ and Ar concentrations in relation to the actual temperature of discharge from Big Spring (fig. 27) provides useful information about depth of ground-water flow through the Ozark aquifer that discharges at Big Spring and Greer Spring and the predominant season of recharge. All of the water samples from Big Spring and Greer Spring have water temperatures warmer than their $\mathrm{N}_{2}-$ Ar recharge temperature. The $\mathrm{N}_{2}-\mathrm{Ar}$ recharge temperatures range from approximately 10.5 to $14{ }^{\circ} \mathrm{C}$ and are in the range of long-term average air temperatures recorded in April $\left(13.0^{\circ} \mathrm{C}\right)$ and October (13.6 ${ }^{\circ} \mathrm{C}$ ) in southeast Missouri (National Oceanic and Atmospheric Administration, 2005). More precipitation occurs in April than in October in southeast Missouri (National Oceanic and Atmospheric Administration, 2005) and it is assumed that evapotranspiration may still be occurring in October and intercepting moisture that would otherwise be used to recharge the ground-water system. Based on this reasoning, the $\mathrm{N}_{2}-\mathrm{Ar}$ recharge temperature data indicates recharge to the Big Spring watershed occurs primarily in late winter to early spring. The water temperatures at Big Spring were slightly warmer than the mean annual temperature in southeast Missouri $\left(12.8^{\circ} \mathrm{C}\right.$; National Oceanic and Atmospheric Administration, 2005) and consistent with relatively shallow circulation (less than about $600 \mathrm{ft}$ ); that is, the discharge from 


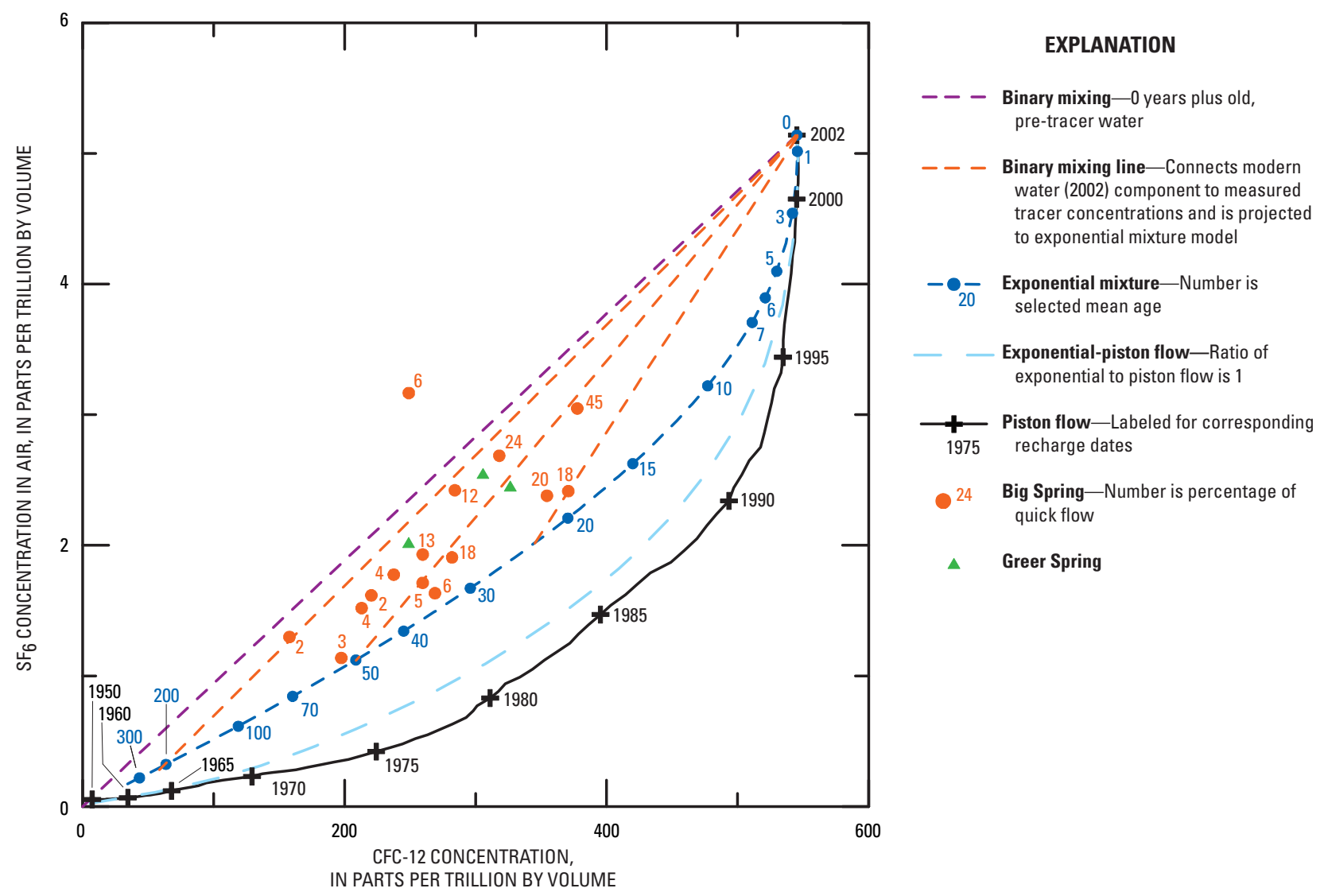

Figure 24. Concentrations of chlorofluorocarbon (CFC-12) and sulfur hexafluoride $\left(\mathrm{SF}_{6}\right)$ in discharge from Big Spring and Greer Spring in relation to several possible mixing models.

Big Spring does not appear to be warmed by deep circulation along a geothermal gradient.

\section{General Water Quality}

Springs are excellent sites for monitoring water quality in karst areas because springs typically are the point to which ground-water flow converges. Unlike water samples from wells that represent the quality of the ground water in the vicinity of the well, the quality of water discharging from a spring is representative of the aquifer in the spring recharge area. In the case of Big Spring, the recharge area includes several hundred square miles.

\section{Water Quality and Dissolution Rates of Carbonate Rock in the Big Spring Recharge Area}

The USGS has collected more than 130 water-quality samples at Big Spring since 1973. These samples were collected for multiple programs with different objectives resulting in a variety of chemical constituent suites being collected using several different sample-collection methods. Water sample-collection methods used over the years include equalwidth increment (EWI) cross sections, grab samples from the spring orifice, and pneumatic pumps placed in the spring orifice. The guidelines and procedures for these collection methods are described by Wilde and others (1999).

Since 1973, water samples from Big Spring have been analyzed for a variety of chemical constituents ranging from physical properties and major ions, nutrients, or indicator bacteria only, to extensive analyte suites including dissolved and total recoverable major and trace inorganic constituents, nutrients, indicator bacteria, pesticides, or stable isotopes. The following discussion of water quality is limited to general observations of selected physical properties, dissolved major cations and anions, nutrients, and indicator bacteria from 1973 through 2005. While the constituents being analyzed in water samples varied over time, these constituents were determined using standard USGS field and laboratory methods. Discharge, specific conductance, $\mathrm{pH}$, water temperature, and alkalinity were determined onsite at the time of sampling. The procedures for performing these field measurements are described by Wilde and Radtke (1998). Water samples for analysis of dissolved chemical constituents were filtered onsite through a $0.45-\mu \mathrm{m}$ (micrometer) membrane filter. Water samples for 

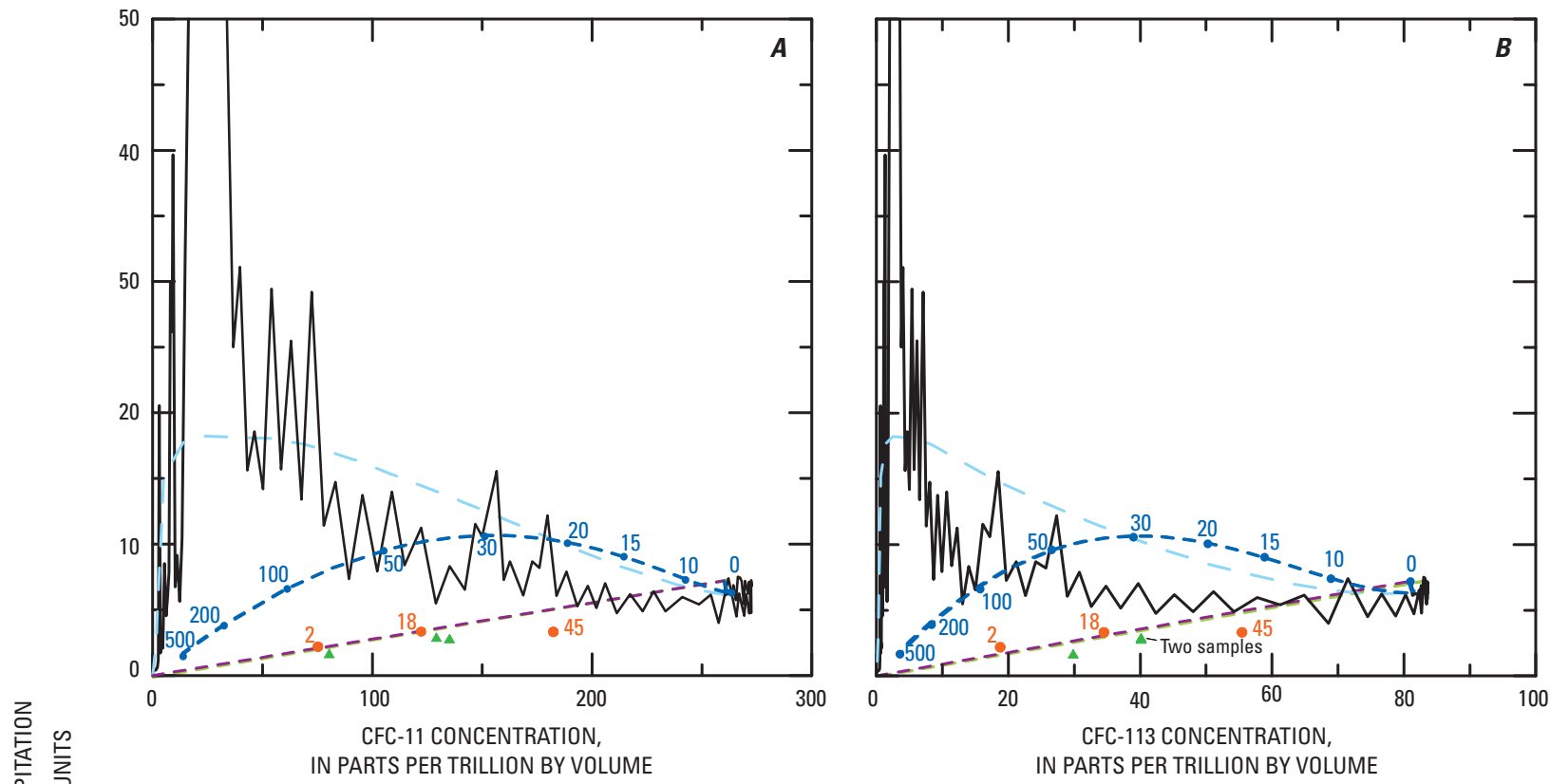

IN PARTS PER TRILLION BY VOLUME

IN PARTS PER TRILLION BY VOLUME

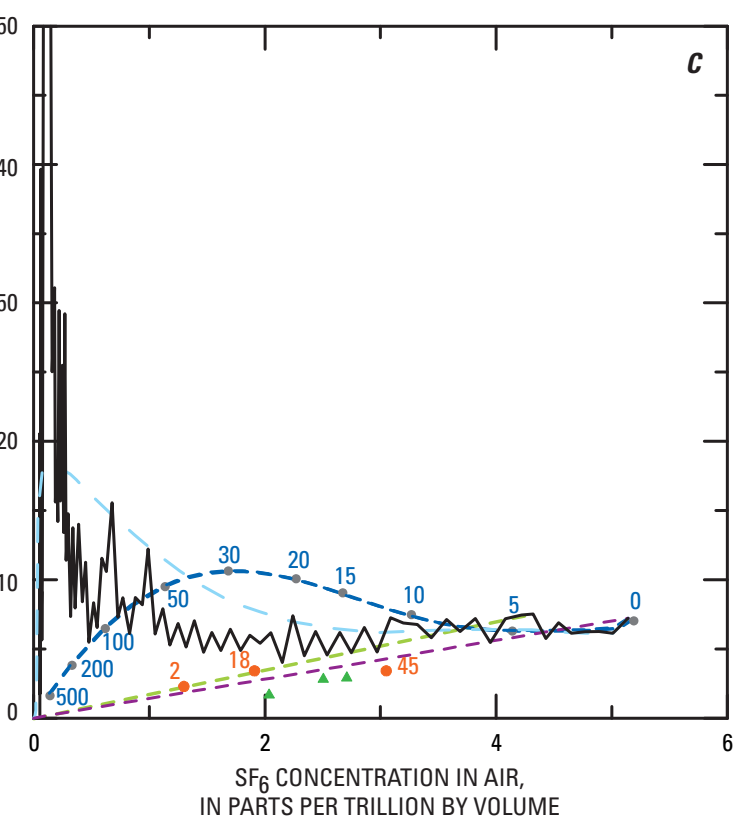

EXPLANATION

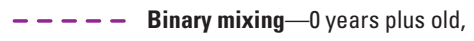
pre-tracer water

- - - - - Binary mixing -4 years plus old, pre-tracer water

_ -20 _ - Exponential mixture - Number is selected mean age

- - Exponential-piston flow

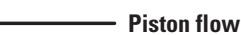

-2 Big Spring-Number is percentage of quick flow

Greer Spring

Note: Values are consistent with a model of dilution of modern water with an old fraction that does not contain tritium.

Figure 25. Tritium concentrations in precipitation, decayed to 2002, with concentrations of chlorofluorocarbons (CFC-11 and CFC-113) and sulfur hexafluoride $\left(\mathrm{SF}_{6}\right)$ in discharge from Big Spring and Greer Spring.

dissolved anions were placed into polyethylene bottles and samples for dissolved cations were placed in acid-washed polyethylene bottles and preserved with ultrapure nitric acid to a $\mathrm{pH}$ less than 2 . All water-quality samples were analyzed by laboratories of the USGS. Water samples were analyzed for inorganic substances according to methods described by Fishman and Friedman (1989). Physical properties and inorganic constituent concentrations in water samples collected from
2000 to 2002 at Big Spring, specifically for this study are in table 9 (at the back of this report). Water quality data collected outside of this study are available at http://nwis.waterdata. usgs.gov/mo/nwis/qwdata accessed April 23, 2007.

Water samples collected at Big Spring from 1973 to 2002 indicate specific conductance values and concentrations of most inorganic constituents, for example, calcium (Ca), magnesium $(\mathrm{Mg})$, sodium $(\mathrm{Na})$, and bicarbonate $\left(\mathrm{HCO}_{3}\right)$ generally 


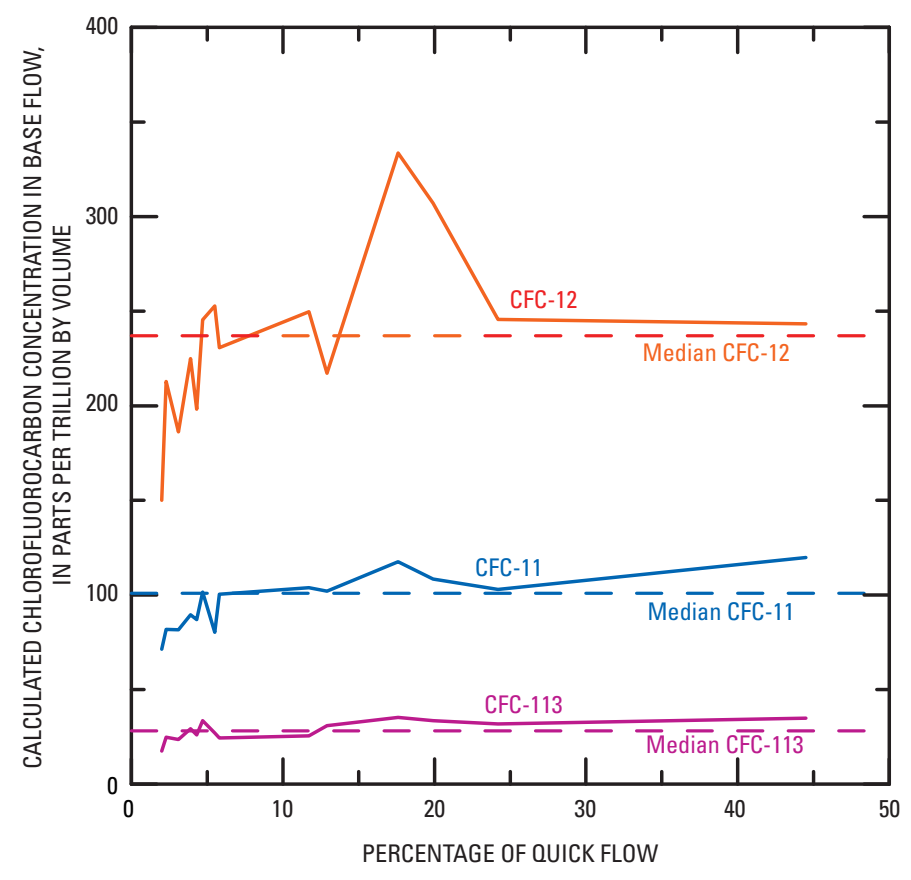

Figure 26. Calculated and median concentrations of chlorofluorocarbons (CFC-11, CFC-12, and CFC-113) in base flow as a function of percentage quick flow for Big Spring discharge.

decreased with increasing discharge (fig. 28). The decrease in constituent concentrations with increasing discharge indicates dilution of these predominantly base flow derived constituents with lower ionic strength quick flow. Concentrations of other constituents such as chloride $(\mathrm{Cl})$ and nitrite plus nitrate

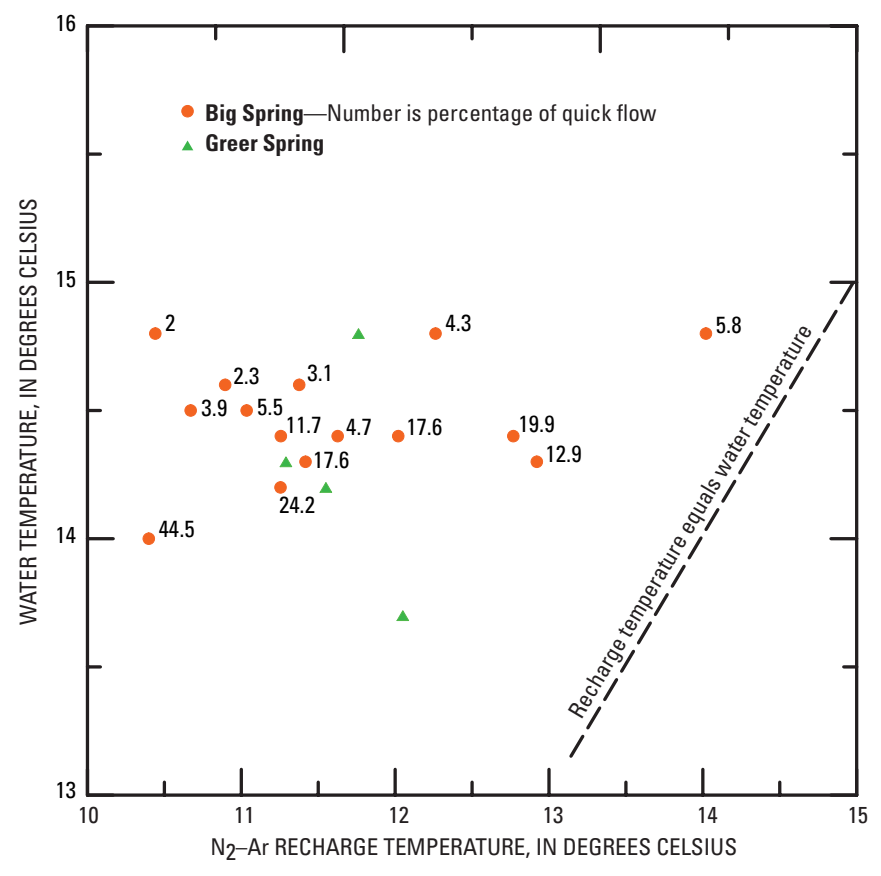

Figure 27. Recharge temperature determined from analyses of dissolved nitrogen $\left(\mathrm{N}_{2}\right)$ and argon (Ar) gas with the fieldmeasured water temperature, 2001-03.
$\left(\mathrm{NO}_{2}+\mathrm{NO}_{3}\right)$, and fecal coliform densities, however, exhibit little or no decrease with increasing discharge, indicating quick flow probably is a more important source of these constituents compared to base flow.

The predominant ions in water samples from Big Spring are $\mathrm{Ca}, \mathrm{Mg}$, and $\mathrm{HCO}_{3}$, which is consistent with the predominance of carbonate rocks in the spring recharge area. Strong positive linear relations existed between specific conductance and concentrations of $\mathrm{Ca}, \mathrm{Mg}$, and $\mathrm{HCO}_{3}\left(\mathrm{r}^{2}\right.$ values of $0.91,0.90$, and 0.76 ), whereas constituents such as $\mathrm{Cl}$ and $\mathrm{NO}_{2}+\mathrm{NO}_{3}$ exhibited no relation with specific conductance $\left(\mathrm{r}^{2}\right.$ values less than 0.10$)$. Strong positive linear relations also existed between barium $(\mathrm{Ba})$ and strontium $(\mathrm{Sr})$ and specific conductance $\left(r^{2}\right.$ values of 0.71 and 0.91$)$. The strong positive linear relations between these major and trace constituents and discharge is related to these constituents being common in carbonate rocks of the Ozark aquifer. Because of the strong positive relation between specific conductance and constituents such as $\mathrm{Ca}, \mathrm{Mg}$, and $\mathrm{Sr}$, specific conductance can be used to estimate concentrations of these constituents when analytical data are not available.

Forty-four water samples collected at Big Spring from 1973 to 2005 plot along the line of carbonic acid weathering (dissolution) of dolomite (fig. 29) and have molar ratios of Ca: $\mathrm{Mg}$ of near 1 (1.00 to 1.18). The dissolution of the mineral dolomite is likely the primary control on concentrations of $\mathrm{Ca}, \mathrm{Mg}$, and $\mathrm{HCO}_{3}$. Dissolution of dolomite and dissolution or precipitation of calcite also buffer the $\mathrm{pH}$ of the solution. Water in contact with dolomite $\left[\mathrm{CaMg}\left(\mathrm{CO}_{3}\right)_{2}\right]$ should dissolve equal molar quantities of $\mathrm{Ca}$ and $\mathrm{Mg}$, whereas water in contact with limestone [composed mostly of the mineral calcite $\left(\mathrm{CaCO}_{3}\right)$ ] will have much larger ratios of $\mathrm{Ca}: \mathrm{Mg}$ (Hem, 1992). Equilibrium-speciation calculations using the geochemical code PHREEQC (Parkhurst and Appelo, 1999) indicates that water samples from Big Spring generally are in equilibrium with the minerals calcite and dolomite. The saturation index (SI), which is the $\log 10$ of the ratio of the ion activity product (IAP) divided by the equilibrium constant (KT), was calculated for calcite and dolomite for all water samples with electrical charge balances within 5 percent (total of 40 samples). The SI indicates whether a mineral should be dissolving (SI less than zero), be at equilibrium (SI of zero), or precipitating (SI greater than zero). Because of analytical error and small uncertainties in thermodynamic data, differences in SI values of plus or minus 0.25 probably are insignificant. SI values for calcite ranged from -1.18 to 0.00 (median of -0.38). Dolomite SI values were smaller, ranging from -2.44 to -0.03 (median of -0.81), indicating general slight undersaturation with respect to dolomite in most samples. The smaller SI values were associated with larger spring discharges, indicating that quick flow water entering the spring conduit system does not reach equilibrium with calcite or dolomite by the time it emerges from the spring orifice. While rocks in the recharge area are predominantly dolomite, secondary calcite is common. Because calcite is more soluble, calcite SI values near zero are not uncommon with dolomite slightly undersaturated. 

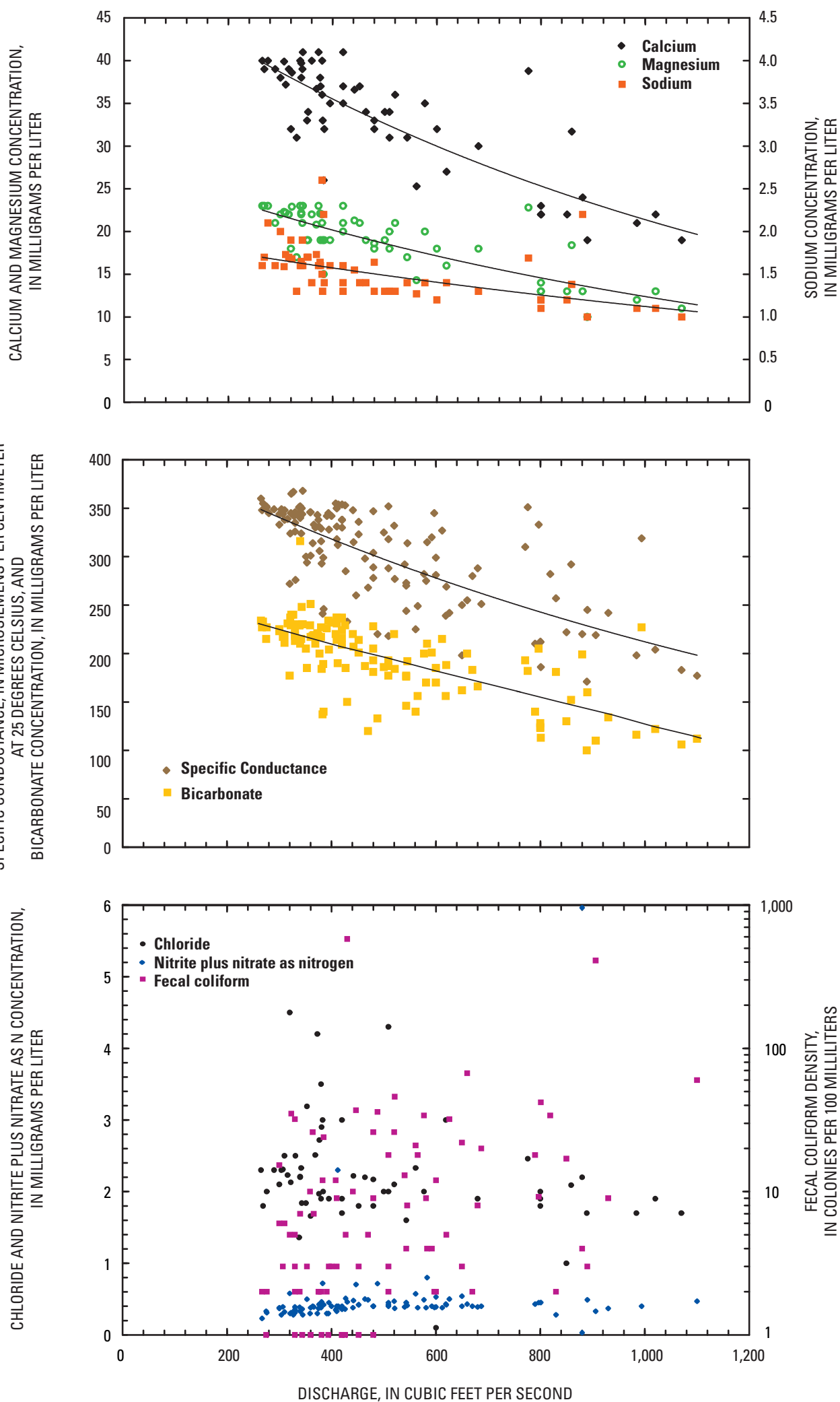

Figure 28. Relations between specific conductance, concentrations of selected inorganic constituents, fecal coliform densities, and discharge at Big Spring, 1973-2002.

Although calcite and dolomite SI values decreased with increasing discharge, molar ratios of $\mathrm{Ca}: \mathrm{Mg}$ exhibited no trends with discharge, indicating that infiltrating runoff water is buffered by a similar process as base-flow water. The near constant molar $\mathrm{Ca}: \mathrm{Mg}$ ratios indicated that dissolution of dolomitic rock in the unsaturated and phreatic conduits of the spring conduit system by infiltrating quick flow contributes to the increase in $\mathrm{Ca}$ and $\mathrm{Mg}$ loads during runoff.

The flux of $\mathrm{Ca}$ and $\mathrm{Mg}$ from Big Spring represents a considerable quantity of bedrock dissolved each day. Assuming all $\mathrm{Mg}$ is derived from dissolution of the mineral dolomite, and using an average $\mathrm{Mg}$ concentration of about $19 \mathrm{mg} / \mathrm{L}$ (milligrams per liter) at the mean annual discharge of $445 \mathrm{ft}^{3} / \mathrm{s}$ (fig. 28), about $157,000 \mathrm{~kg}$ (173 tons) of dolomitic bedrock, is dissolved in the Big Spring recharge area each day. This mass of dolomite represents a volume of about $1,950 \mathrm{ft}^{3}$ or a cube of rock $12.5 \mathrm{ft}$ on each side is dissolved each day.

\section{Estimated Annual} Suspended Sediment
Load of Big Spring

Suspended sediment concentrations (table 10, at the back of this report) in water samples from Big Spring were determined to estimate the suspended sediment load from the spring. Suspended sediment samples were collected about $1,500 \mathrm{ft}$ downstream from the spring when the spring branch was wadable and at the NPS bridge during high stages. Samples were collected with a depth-integrating sampler using the EWI method and at a single point in 


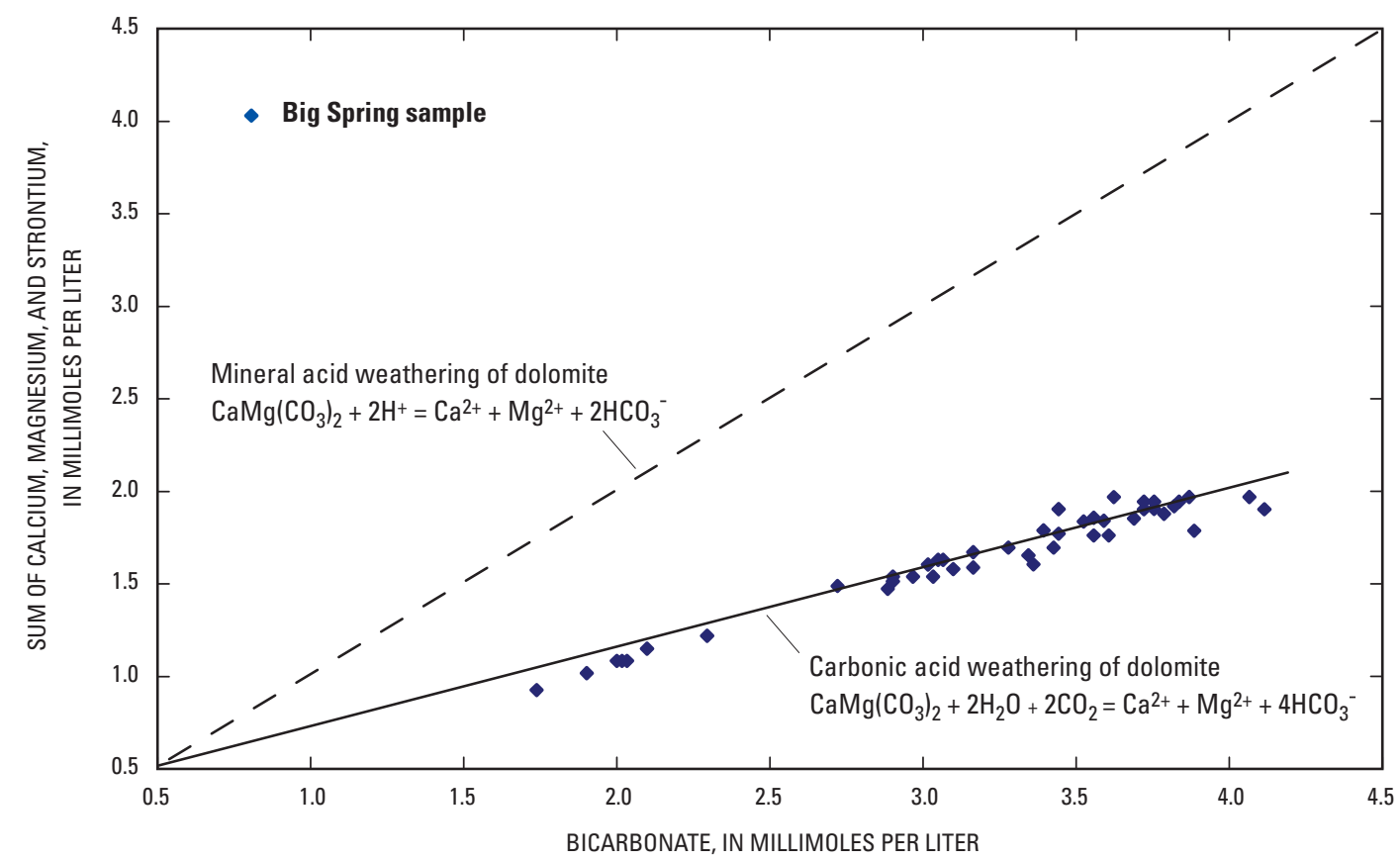

Figure 29. Relation between bicarbonate and the sum of calcium, magnesium, and strontium, 1973-2005.

the spring branch channel using an automatic sampler. All suspended sediment concentrations were determined in the USGS sediment laboratory in Rolla, Missouri. Before June 20, 2002, and from November 2003 to February 2004, suspended sediment concentrations were determined using the evaporation method (Guy, 1969). Samples collected at all other dates were analyzed using the filtration method (Guy, 1969). During evaporation method analyses of Big Spring water samples, dissolved solids concentration in the small quantity of supernatant water left in the sample bottle after decanting typically was greater than the suspended sediment concentration of the sample. Consequently, the filtration method was adopted for the suspended sediment analyses because it is more accurate identifying the smaller suspended sediment concentrations in

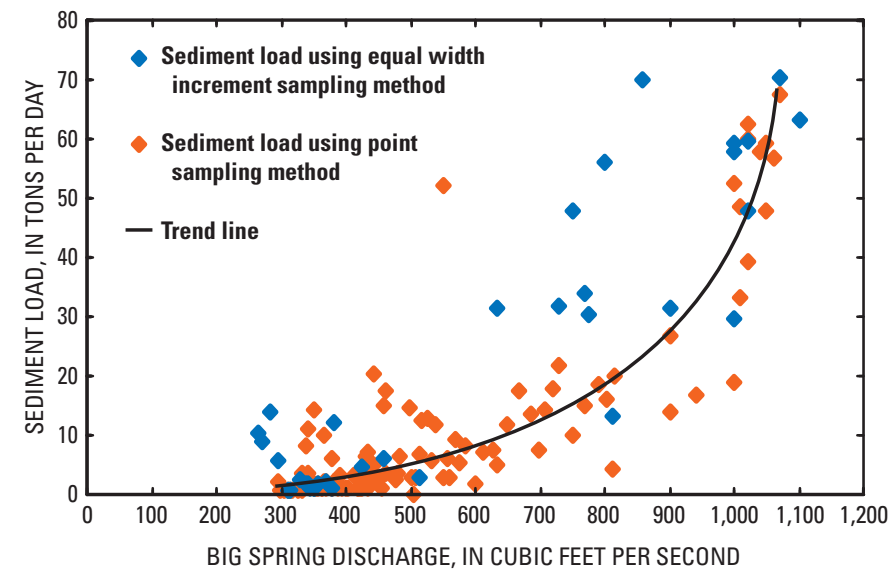

Figure 30. Suspended sediment load in water discharging from Big Spring, 2001-04. extremely clear water than the evaporation method. Most of the high-discharge suspended sediment samples were already collected and analyzed using the evaporation method before this issue was identified.

In an attempt to combine the two data sets from the different analysis methods, a cursory experiment was performed on a Big Spring water sample to determine the suspended sediment and dissolved solids concentrations that would typically be measured and reported using the evaporation method. The water sample was pumped through a filtration crucible to gather the suspended sediment, and the filtered water containing the dissolved solids was collected. The water containing the dissolved solids was processed using the evaporation method and the suspended sediment portion was processed using the filtration method. The results showed the suspended sediment concentration was $1.5 \mathrm{mg} / \mathrm{L}$ and the dissolved solids concentration was $17.1 \mathrm{mg} / \mathrm{L}$.

A correction was applied to the reported suspended sediment concentrations based on TDS concentrations estimated from Big Spring specific conductance measurements and the estimated volume of water left in the evaporation dish during decanting. Because of the good correlation $\left(r^{2}\right.$ value of 0.98 ) between TDS concentrations and specific conductance values from Big Spring, the TDS concentrations could be accurately estimated from the specific conductance (SC) data $(\mathrm{TDS}=0.5239 * \mathrm{SC})$. The largest unknown variable in the applied correction to the evaporation-method concentrations is the amount of water left in the evaporation dish after decanting. During simulated trials, the supernatant liquid left in the evaporation dish was typically about $90 \mathrm{~mL}$ (milliliters) plus or minus $5 \mathrm{~mL}$. 
Because the suspended sediment concentration of each sample is small and concerns associated with the analytical methods caused additional uncertainty in the measured sediment concentrations, an accurate comparison was not possible between sediment concentrations obtained from samples using the EWI method and the point sampler method. However, because of the severe turbulence at the orifice of Big Spring, the distance from the spring to the sediment sampling sites is small, and the sediment particles primarily are clay size, the sediment likely is well mixed across the spring branch channel and the point sampling method approximates the EWI sampling method.

Suspended sediment concentrations from both sampling methods (adjusted evaporation and filtration methods) were used with estimated spring discharge to calculate sediment loads carried by Big Spring (table 10; fig. 30). The suspended sediment load conveyed by Big Spring ranged from about 1 to about 70 ton/d (tons per day). Visual observations during high flow indicate the spring water does not become brown because of the sediment load, but normally becomes a light green. Sediment load increases as discharge increases, and the rate of increase is larger when discharge exceeds about $800 \mathrm{ft}^{3} / \mathrm{s}$. The sediment load during base-flow periods ranged from about 1 to about 7 ton/d.

\section{Summary and Conclusions}

Southeastern Missouri has been a prominent lead-mining area since shortly after the first French explorations occurred in the area in about 1700. In anticipation of future declining reserves of lead ore, mining companies have explored in a mature karst area of the Mark Twain National Forest, of southeastern Missouri. This is a highly valued and environmentally sensitive area because of its scenic beauty and recreational opportunities. The area contains the two largest springs in Missouri (Big Spring and Greer Spring) both of which flow into federally designated scenic rivers, along with other smaller springs. Concerns exist that mine dewatering in this area could lower water levels and cause a decrease in groundwater discharge to the springs. Also, the presence of losing streams in the exploration area is of concern because contaminants released during mining activities or from stored mine waste (tailings piles) potentially can migrate into the groundwater flow system. This could degrade the quality of water at nearby springs and threaten aquatic biota. The investigation of Big Spring is part of a larger investigation of the geology, hydrology, and aquatic biology of the exploration area initiated by these environmental concerns.

Water levels were measured or observed in 346 wells and 7 springs during the summer and fall 2000 to better define the recharge areas of Big Spring, Greer Spring, Mammoth Spring, and Boze Mill Spring. Ground-water levels generally were low because of the dry conditions and even lower in the mature karst terrain. Measured depth-to-water in summer 2000 ranged from 2.1 to 448.4 feet, but exceeded 200 feet in most wells located in the mature karst headwater areas of the
Eleven Point River, Spring Creek, Hurricane Creek, and Pike Creek. Two distinct potentiometric surfaces can be inferred from the water-level data. The shallow potentiometric surface, representing the water table where the depth-to-water was less than about 250 feet, tends to mimic topographic features and is strongly controlled by streams. The deep potentiometric surface represents ground-water hydraulic heads within the more mature karst areas where the depth-to-water was greater than about 250 feet. The deeper potentiometric surface indicates the presence of a highly permeable zone extending about 20 mile west of Big Spring toward the upper Hurricane Creek Basin. Deeper flowing water in the Big Spring recharge area is directed toward this permeable zone. A similar highly permeable zone extends about 10 miles west of Greer Spring, then trends to the northwest about 20 miles. The estimated sizes of the spring recharge areas are 426 square miles for Big Spring, 352 square miles for Greer Spring, 290 square miles for Mammoth Spring, and 54 square miles for Boze Mill Spring.

A discharge accumulation curve using Big Spring daily mean discharge data shows no substantial change in the discharge pattern of Big Spring occurred during the period of record, (water years 1922 through 2004) and observed longterm variations in spring discharge can be attributed to prolonged departures from normal precipitation. The quality of the computed spring discharge (using Big Spring stage-discharge rating curve and staff measurements) has been impaired by two factors. During low-flow conditions, thick watercress beds in the spring branch impede the natural movement of the flowing water and cause a higher-than-normal gage-height reading. During high-flow conditions increased flow in the Current River blocks the mouth of the spring branch and backwater causes a higher-than-normal gage-height reading. Also, at gage heights above about 9.5 feet water from the Current River flows over its banks upstream from Big Spring and enters the spring pool immediately downstream from the spring, but upstream from the gage on the NPS bridge. This additional river water is gaged along with the spring discharge causing additional complications in the stage-discharge relation. The entire area is inundated when the gage height reaches about 11 feet.

The maximum possible instantaneous flow from Big Spring has not been adequately defined because of backwater effects from the Current River during high-flow conditions. Physical constraints within the spring conduit system may restrict its maximum flow. The largest discharge measured at Big Spring during the period of record was 1,170 cubic feet per second on December 7, 1982.

To better determine the discharge from Big Spring, an acoustic Doppler system was installed to measure and record stream velocities in the spring branch. At low stage, acoustic Doppler-measured water velocities are about 2.5 feet per second, and the velocity data indicate considerable scatter for gage heights less than about 3 feet because of the presence of water cress in the channel. Above about a 3.0 feet stage, water velocities drop abruptly to about 1.5 feet per second as the backwater effect of the Current River stage propagates up the spring branch. Comparison of the calculated mean velocity 
(measured discharge divided by channel cross sectional area) to the acoustic Doppler velocity shows that the calculated mean velocity is smaller than the measured acoustic Doppler velocity when stage at the bridge is lower than about 3.0 feet. At higher stage (about 6 to nearly 10 feet), the calculated velocity is uniformly larger than the acoustic Doppler velocity by about 0.10 to 0.20 feet per second. For spring branch stages above 3.5 to 4.0 feet, the relation between stage and water velocities is more uniform, and the acoustic Doppler velocity data may be used to refine discharge data normally derived directly from the stage-discharge curve for Big Spring.

The daily mean water temperature of Big Spring for the water years 2001 through 2004 (October 2000 through September 2004) had little variability, ranging from 13 to $15^{\circ} \mathrm{C}$ (degree Celsius). Water temperatures generally vary less than $1{ }^{\circ} \mathrm{C}$ throughout the year. Lower daily mean water temperatures were recorded $\left(13.1\right.$ to $13.5^{\circ} \mathrm{C}$ ) from March to April 2002. During the 2001 through 2004 water years, there were many times when the daily mean spring water temperature dropped below $14.0{ }^{\circ} \mathrm{C}$, and each time was during or immediately following intense storms that occurred during the winter or spring. The warmest temperatures occur during October and November, traditionally low-flow periods, and the temperature decreases until April at which time water temperatures begin to increase. This indicates the water temperature in Big Spring shows a slight seasonal variation. The specific conductance values of water flowing from Big Spring is a result of the mixing of waters of different specific conductance. Water that has moved more slowly through the karst terrain and surrounding bedrock in the Big Spring recharge area accumulates dissolved solids to an equilibrium concentration that yields higher specific conductance values than water that moves more quickly through the larger fractures and conduits of the recharge area in response to intense rainfall.

Specific conductance of water from Big Spring (measured from October 2000 to September 2004) stabilized at about 357 microsiemens per centimeter at 25 degrees Celsius during extended periods of little rainfall, or moderate rainfall insufficient to cause measurable increase in spring discharge. During intervals of intense rainfall, or prolonged periods of moderate rainfall, water of lower specific conductance values that enters the larger fractures and conduits in the Big Spring recharge area quickly moves towards the spring orifice and discharges before reaching chemical equilibrium with the surrounding rock. The specific conductance of the ground water that discharges at the spring decreases as the ratio of quick-flowing water in the large fractures increases relative to the slowerflowing water in the smaller fractures. Observation of the rise in specific conductance values after a rainfall-induced decline shows that the recovery is slow and that the specific conductance approaches pre-storm values exponentially with time.

Base flow is defined herein as the component of spring flow derived from water that has traveled a long time through smaller fractures and pore space in the bedrock, and quick flow is associated with rapid transport of water to a spring through larger fractures following storm events. Dye-trace investigations in the Big Spring recharge area show that (1) quick flow from the eastern part of the recharge area can take 6 to 12 days to reach the spring at a rate of 1.5 to 3 miles per day, (2) quick flow from the central part of the recharge area can take 8 to 11 days to reach the spring, and flow at a rate of 1.5 to 2 miles per day, and (3) quick flow from the western part of the recharge area can take 42 days to reach the spring at a rate of 0.9 mile per day.

The computer program HYSEP was used to separate the Big Spring hydrograph into base-flow and quick-flow components for water years 2001 to 2004. The HYSEP analysis predicted that base-flow discharge was the dominant source of water that sustained spring flow, quick-flow discharge was small as compared to the base-flow discharge, but failed to yield base-flow and quick-flow discharge curves that matched observations of spring characteristics. Big Spring discharge data were used in combination with specific conductance data to develop an improved hydrograph separation method (discharge and specific conductance method) for the spring. The estimated annual mean quick flow ranged from 15 to 48 cubic feet per second for the HYSEP analysis, and ranged from 26 to 154 cubic feet per second for the discharge and specific conductance method. The discharge and specific conductance method consistently estimated a larger percentage of quick flow for each of the 4 water years.

During periods characterized by large and abrupt rises in the spring hydrograph, HYSEP calculated a linear increase or decrease in base flow, which apparently is a function of the length of time from the onset of a substantial rise in the hydrograph to the next recharge-induced rise. At nine major or more-isolated hydrograph peaks, HYSEP estimated quick flow rose abruptly and peaked on the same day as the discharge hydrograph peak, then declined to near zero within a month. The abrupt decline in quick-flow discharge appears to be inconsistent with quick-flow traveltimes estimated from dye-trace investigations.

Using the discharge and specific conductance method of hydrograph separation, the estimated base-flow component rises abruptly as the spring hydrograph rises, and attains a peak value on the same day as the discharge peak. The base-flow component declines abruptly from its peak value, and then several days later base flow begins to increase at an approximately linear trend. The onset of the period of linear rise in base flow appears to coincide with the time at which the percentage of quick flow has reached a maximum after each recharge-induced discharge peak. The time interval between the discharge peak and the peak in percentage quick flow ranges from 8 to 11 days for seven hydrograph peaks, consistent with large amounts of recharge and quick-flow traveltime estimates by dye-trace tests from the mature karst Hurricane Creek Basin in the central part of the recharge area. The incorporation of specific conductance values into the hydrograph separation process for springs can yield more reasonable hydrograph separation results than HYSEP.

The environmental tracers, chlorofluorocarbons (CFCs: CFC-11, CFC-12, CFC-113), sulfur hexafluoride ( $\left.\mathrm{SF}_{6}\right)$, 
and tritium $\left({ }^{3} \mathrm{H}\right)$ were used to test the discharge and specific conductance hydrograph separation model, estimate ages of quick-flow and base-flow components, and estimate mixing fractions. The concentrations of CFC-11, CFC-12, CFC-113, and $\mathrm{SF}_{6}$ in discharge from Big Spring vary approximately linearly with percent quick flow from about 5 to 45 percent of discharge. Extrapolation of the linear relation to 100 percent quick flow implies $\mathrm{CFC}$ and $\mathrm{SF}_{6}$ concentrations nearly identical to those in the 2002 atmosphere, and indicates a modern age for the quick-flow component. As percent quick flow falls below about 5 percent, the tracer concentrations fall below the values extrapolated to zero percent quick flow, which indicates that the reservoir of older water in the Big Spring watershed may be a series of water mixtures with piston-flow ages greater than those obtained by extrapolation to zero percent quick flow. Each sample point with a low percentage of quick flow (less than 5 percent) may be a unique mixture.

Tracer-tracer plots were used to examine several morecomplex mixing models such as exponential mixing (an average of the ages of all the flow lines discharging from the spring) and exponential-piston flow mixtures. The environmental tracer data from Big Spring plot intermediate to the simple binary mixing of modern and old, pre-tracer water and results from the exponential mixture model. The mean ages of waters in the base-flow component, derived from extrapolation of binary mixing lines between the modern (2002) component and intersection with the exponential model, and passing through the measured tracer concentration points, approximately range from 30 to 200 years. The mean age of the base-flow component is youngest (30 to 40 years) in samples containing the highest quick-flow component (45 percent quick flow) and increases to 200 years or more as the fraction of quick flow decreases to less than 5 percent.

Tritium data from Big Spring and Greer Spring in relation to $\mathrm{CFC}-11$, CFC-113, and $\mathrm{SF}_{6}$ are consistent with a model of dilution of a modern component with an old, pre-tracer component and indicates that the old fraction is mostly pre-1960s in age, and if an exponential mixture, the mean residence time would be more than several hundred years to be consistent with the measured tritium values. The equations derived for hydrograph separation using discharge and specific conductance also are applicable to $\mathrm{CFC}$ and $\mathrm{SF}_{6}$ tracer concentrations. Using the calculated values of percent quick flow (from the discharge and specific conductance hydrograph separation method), calculated median concentrations of CFC-11, CFC12, CFC-113 and $\mathrm{SF}_{6}$ in base flow were 100.9, 237, 28.1, and 1.4 parts per trillion by volume. The calculated CFC concentrations of the base-flow component is nearly constant when percent quick flow is greater than about 5 percent of spring discharge, but decreases as percent quick flow decreases to less than 5 percent, implying older ages in the highest fraction of base flow. If the exponential model applies, the calculated base-flow concentrations indicate mean ages of 40 to more than 200 years, suggesting some age stratification is present in the older resident water in the Ozark aquifer.
All of the water samples from Big Spring and Greer Spring have water temperatures warmer than their $\mathrm{N}_{2}-\mathrm{Ar}$ recharge temperature, which range from approximately 10.5 to $14{ }^{\circ} \mathrm{C}$. This suggests recharge to the Big Spring watershed occurs primarily in late winter to early spring. The water temperatures at Big Spring are consistent with relatively shallow circulation (less than about 600 feet), and does not appear to be warmed by deep circulation along a geothermal gradient.

Specific conductance values and concentrations of most inorganic constituents in water samples from Big Spring generally decrease with increasing discharge indicating dilution of these predominately base flow derived constituents with lower ionic strength runoff water, or quick flow. Concentrations of some constituents such as chloride $(\mathrm{Cl})$ and nitrite plus nitrate $\left(\mathrm{NO}_{2}+\mathrm{NO}_{3}\right)$, and fecal coliform densities, however, exhibit little or no decrease with increasing discharge indicating that quick flow is probably a more important source of these constituents compared to base flow. The predominant ions in water from Big Spring are calcium $(\mathrm{Ca})$, magnesium $(\mathrm{Mg})$, and bicarbonate $\left(\mathrm{HCO}_{3}\right)$, which is consistent with the predominance of carbonate rocks in the spring recharge area. Water samples from Big Spring plot along the line of dolomite dissolution by carbonic acid, and have a molar ratio of $\mathrm{Ca}: \mathrm{Mg}$ of near 1 , indicating dissolution of the mineral dolomite as the primary control on concentrations of $\mathrm{Ca}, \mathrm{Mg}$, and $\mathrm{HCO}_{3}$. Equilibrium-speciation calculations indicate that water samples from Big Spring generally are in equilibrium with the minerals calcite and dolomite. The flux of $\mathrm{Ca}$ and $\mathrm{Mg}$ from Big Spring represents the dissolution of about 1,950 cubic feet of dolomite per day.

The suspended sediment load of Big Spring was estimated to range from about 1 to 70 tons per day. The sediment load during base-flow periods ranged from about 1 to about 7 tons per day.

\section{References Cited}

Aley, Thomas, 1975, A predictive hydrologic model for evaluating the effects of land use and management on the quantity and quality of water from Ozarks springs: Protem, Mo., Ozark Underground Laboratory, 236 p. with appendices.

Alternative Fluorocarbons Environmental Acceptability Study, 2006a, accessed August 23, 2006, at URL http://www.afeas. org.

Alternative Fluorocarbons Environmental Acceptability Study, 2006b, accessed August 23, 2006, at URL http://www.afeas. org/montreal_protocol.html.

Burford, J., 1978, Underground treasures: The story of mining in Missouri, in Official Manual State of Missouri 19771978, K.M. Johnson, ed., p. 1-33.

Busenberg, E., and Plummer, L.N., 1992, Use of chlorofluorocarbons $\left(\mathrm{CCl}_{3} \mathrm{~F}\right.$ and $\left.\mathrm{CCl}_{2} \mathrm{~F}_{2}\right)$ as hydrologic tracers and agedating tools: Example_-The alluvium and terrace system of 
central Oklahoma: Water Resources Research, v. 28, no. 9, p. 2,257-2,284.

Busenberg, E., and Plummer, L.N., 1997, Use of sulfur hexafluoride as a dating tool and as a tracer of igneous and volcanic fluids in groundwater: Geological Society of America, Annual Meeting, GSA Abstracts with Programs, v. 29, no. 6, p A-78.

Busenberg E., and Plummer, L.N., 2000, Dating young ground water with sulfur hexafluoride: Natural and anthropogenic sources of sulfur hexafluoride: Water Resources Research, v. 36 no. 10 , p. 3,011-3,030.

Cook, P.G., and Solomon, D.K., 1995, The transport of atmospheric trace gases to the water table: Implications for groundwater dating with chlorofluorocarbons and krypton85: Water Resources Research, v. 31, p. 263-270.

Cook, P.G., and Böhlke, J.K., 1999, Determining time scales for groundwater flow and solute transport using environmental tracers, in Cook, P.G., and Herczeg, A., eds., Environmental tracers in subsurface hydrology: Boston, Kluwer Academic Publishers, p. 1-30.

Fishman, M.J., and Friedman, L.C., 1989, Methods for determination of inorganic substances in water and fluvial sediments: U.S. Geological Survey Techniques of WaterResources Investigations, book 5, chapter A1, 545 p.

Gamlen, P.H., Lane, B.C., Midgley, P.M., and Steed, J.M., 1986, The production and release to the atmosphere of $\mathrm{CCl}_{3} \mathrm{~F}$ and $\mathrm{CCl}_{2} \mathrm{~F}_{2}$ (chlorofluorocarbons $\mathrm{CFC} 11$ and $\mathrm{CFC}$ 12): Atmosphere Environment, v. 20, p. 1,077-1,085.

Guy, H.P., 1969, Laboratory theory and methods for sediment analysis: U.S. Geological Survey Techniques of WaterResources Investigations, book 5, chapter C1, 58 p.

Harnisch, J., and Eisenhauer, A., 1998, Natural $\mathrm{CF}_{4}$ and $\mathrm{SF}_{6}$ on Earth, 1998: Geophysical Research Letters, v. 25, p. 2,401-2,404.

Hauck, H.S., and Harris, T.E., 2006, Water resources dataMissouri water year 2005: U.S. Geological Survey WaterData Report MO-05-1, 724 p. (published annually).

Hem, J.D., 1992, Study and interpretation of the chemical characteristics of natural water ( $3 \mathrm{~d}$ ed.): U.S. Geological Survey Water-Supply Paper 2254, 263 p.

Imes, J.L., 1990a, Major geohydrologic units in and adjacent to the Ozark Plateaus province, Missouri, Arkansas, Kansas, and Oklahoma-Ozark aquifer: U.S. Geological Survey Hydrologic Investigations Atlas HA-711-E, 3 sheets.

Imes, J.L., 1990b, Major geohydrologic units in and adjacent to the Ozark Plateaus province, Missouri, Arkansas, Kansas, and Oklahoma-St. Francois aquifer: U.S. Geological Survey Hydrologic Investigations Atlas HA-711-C, 2 sheets.
Imes, J.L., 1990c, Major geohydrologic units in and adjacent to the Ozark Plateaus province, Missouri, Arkansas, Kansas, and Oklahoma-St. Francois confining layer: U.S. Geological Survey Hydrologic Investigations Atlas HA-711-D, 3 sheets.

Imes, J.L., 2002, Environmental issues and investigations associated with lead-zinc mining in a proposed new mining district and the Viburnum Trend Mining District of southeastern Missouri: U.S. Geological Survey Fact Sheet 005-02, 6 p.

Imes, J.L., and Emmett, L.F., 1994, Geohydrology of the Ozark Plateaus aquifer system in parts of Missouri, Arkansas, Oklahoma, and Kansas: U.S. Geological Survey Professional Paper 1414-D, 127 p.

Imes, J.L., and Fredrick, B.S., 2002, Using dye-tracing and chemical analyses to determine effects of a wastewater discharge to Jam Up Creek on water quality of Big Spring, southeastern Missouri, 2001: U.S. Geological Survey Fact Sheet 103-02, 6 p.

Imes, J.L., and Kleeschulte, M.J., 1995, Seasonal groundwater level changes (1990-93) and flow patterns in the Fristoe Unit of the Mark Twain National Forest, southern Missouri: U.S. Geological Survey Water-Resources Investigations Report 95-4096, 1 sheet.

International Atomic Energy Agency, 2006, Use of chlorofluorocarbons in hydrology: A Guidebook: International Atomic Energy Agency, Vienna, STI/PUB/1238, 277 p.

Kleeschulte, M.J., 2000, Ground- and surface-water relations in the Eleven Point and Current River Basins, south-central Missouri: U.S. Geological Survey Fact Sheet 032-00, 6 p.

Kleeschulte, M.J., 2001, Effects of lead-zinc mining on ground-water levels in the Ozark aquifer in the Viburnum Trend, southeastern Missouri: U.S. Geological Survey Water-Resources Investigations Report 00-4293, 28 p.

Kleeschulte, M.J., and Seeger, C.M., 2000, Depositional environment, stratigraphy, and vertical hydraulic conductivity of the St. Francois confining unit in the Fristoe Unit of the Mark Twain National Forest, Missouri: U.S. Geological Survey Water-Resources Investigations Report 00-4037, 65 p.

Kleeschulte, M.J., and Seeger, C.M., 2001, Stratigraphy and vertical hydraulic conductivity of the St. Francois confining unit in townships 25-27 N. and ranges 01-02 W., southeastern Missouri: U.S. Geological Survey Water-Resources Investigations Report 01-4270, 64 p.

Kleeschulte, M.J., and Seeger, C.M., 2003, Stratigraphy and vertical hydraulic conductivity of the St. Francois confining unit in the Viburnum Trend and evaluation of the unit in the Viburnum Trend and exploration areas, southeastern Mis- 
souri: U.S. Geological Survey Water-Resources Investigations Report 03-4329, $57 \mathrm{p}$.

Lucas, L. L., and Unterweger, M.P., 2000, Comprehensive review and critical evaluation of the half-life of tritium: Journal of Research, National Institute of Standards and Technology, v. 105, no. 4, p. 541-549.

Maiss, M., and Brenninkmeijer, C.A.M., 1998, Atmospheric $\mathrm{SF}_{6}$ : Trends, sources and prospects: Environmental Science and Technology, v. 32, p. 3,077-3,086.

Maiss, M., and Levin, I., 1994, Global increase of $\mathrm{SF}_{6}$ observed in the atmosphere: Geophysical Research Letters, v. 21, p. $569-572$.

Michel, R.L., 1989, Tritium deposition over the continental United States, 1953-1983, Atmospheric Deposition: Oxfordshire, United Kingdom, International Association of Hydrological Sciences, p. 109-115.

Michel, R.L., 2005, Tritium in the Hydrologic Cycle, in Aggarwal, P.K., Gat, J.R., and Froehlich, K.F.O., eds., Isotopes in the water cycle: past, present, and future of a developing science: Springer, Dordrecht, p. 53-66.

Midgley, P.M., and Fisher, D.A., 1993, Production and release to the atmosphere of chlorodifluoromethane (HCFC-22): Atmosphere Environment, v. 27A, p. 2,215-2,223.

National Oceanic and Atmospheric Administration, 1922-2005, Climatological data annual summary, Missouri: Asheville, North Carolina, National Climatic Center, v. 26-108, no. 13.

Orndorff, R.C., Weary, D.J., and Harrison, R.W., Harman, R.S. and Wick, C.M. (eds.), 2006, The role of sandstone in the development of an Ozark karst system, in Perspectives on karst geomorphology, hydrology, and geochemistry-A tribute volume to Derek C. Ford and William B. White:, Geological Society of America Special Paper 404, p. 31-38.

Parkhurst, D.L., and Appelo, C.A.J., 1999, User's guide to PHREEQC - A computer program for speciation, batchreaction, one-dimensional transport, and inverse geochemical calculations: U.S. Geological Survey Water-Resources Investigations Report 99-4259, 312 p.

Plummer, L.N., and Busenberg, E., 1999, Chlorofluorocarbons, in P. Cook and A. Herczeg (eds.), Environmental tracers in subsurface hydrology, chapter 15, Kluwer Academic Press, p. 441-478.

Plummer, L.N., Busenberg, E., Böhlke, J.K., Nelms, D.L., Michel, R.L., and Schlosser, P., 2001, Groundwater residence times in Shenandoah National Park, Blue Ridge Mountains, Virginia: USA: A multi-tracer approach: Chemical Geology, v. 179, no. 1-4, p. 93-111.
Rantz, S.E., and others, 1982, Measurement and computation of streamflow-volume 1 and 2: U.S. Geological Survey Water-Supply Paper 2175, $631 \mathrm{p}$.

Rozanski, K., Gonfiantini, R., and Araguás-Araguás, L., 1991, Tritium in the global atmosphere: Distribution patterns and recent trends: Journal of Physics G: Nuclear and Particle Physics, v. 17, p. S523-S536.

Rutledge, A.T., 1998, Computer programs for describing the recession of ground-water discharge and for estimating mean ground-water recharge and discharge from streamflow data-update: U.S. Geological Survey Water-Resources Investigations Report 98-4148, 43 p.

Sloto, R.A., and Crouse, M.Y., 1996, HYSEP: A computer program for streamflow hydrograph separation and analysis: U.S. Geological Survey Water-Resources Investigations Report 96-4040, 46 p.

University of Missouri-Columbia, 2006, University of Missouri information, accessed June 28, 2006, at URL http:// www.drought.unl.edu/dm/archive/99/drmon0928.htm.

U.S. Geological Survey, 2006a, The Reston Chlorofluorocarbon Laboratory, accessed May 26, 2006, at URL http:// water.usgs.gov/lab/softwarelair_curve.

U.S. Geological Survey, 2006b, The Reston Chlorofluorocarbon Laboratory, accessed May 26, 2006, at URL http:// water.usgs.gov/lab/cfc.

Vineyard, J.D., and Feder, G.L., 1982, Springs of Missouri: Rolla, Missouri, Missouri Division of Geology and Land Survey Water Resources Report 29, 212 p.

Waite, L.A., Hatten, D.O., and Cross, P.W., 1984, Water resources data-Missouri water year 1983: U.S. Geological Survey Water-Data Report MO-84-1, 293 p.

Warner, D.L., Fletcher, C.S., and Cesare, J.A., 1974, Effect of mining operations on ground water levels in the New Lead Belt, Missouri: Rolla, University of Missouri, Project Number A-060-MO, $86 \mathrm{p}$.

Wells, J.V.B., 1955, Compilation of records of surface waters of the United States through September 1950, Part 7 Lower Mississippi River Basin: U.S. Geological Survey WaterSupply Paper 1311, 606 p. with plate.

Wilde, F.D., and Radtke, D.B., 1998, National field manual for the collection of water-quality data: Field measurements: U.S. Geological Survey Techniques of Water-Resources Investigations, book 9, chapter A6, $238 \mathrm{p}$.

Wilde, F.D., Radtke, D.B., Gibs, Jacob, Iwatsubo, R.T., 1999, National field manual for the collection of water-quality data: Collection of water samples: U.S. Geological Survey Techniques of Water-Resources Investigations, book 9 , chapter A4, 103 p. with appendices. 

Tables 


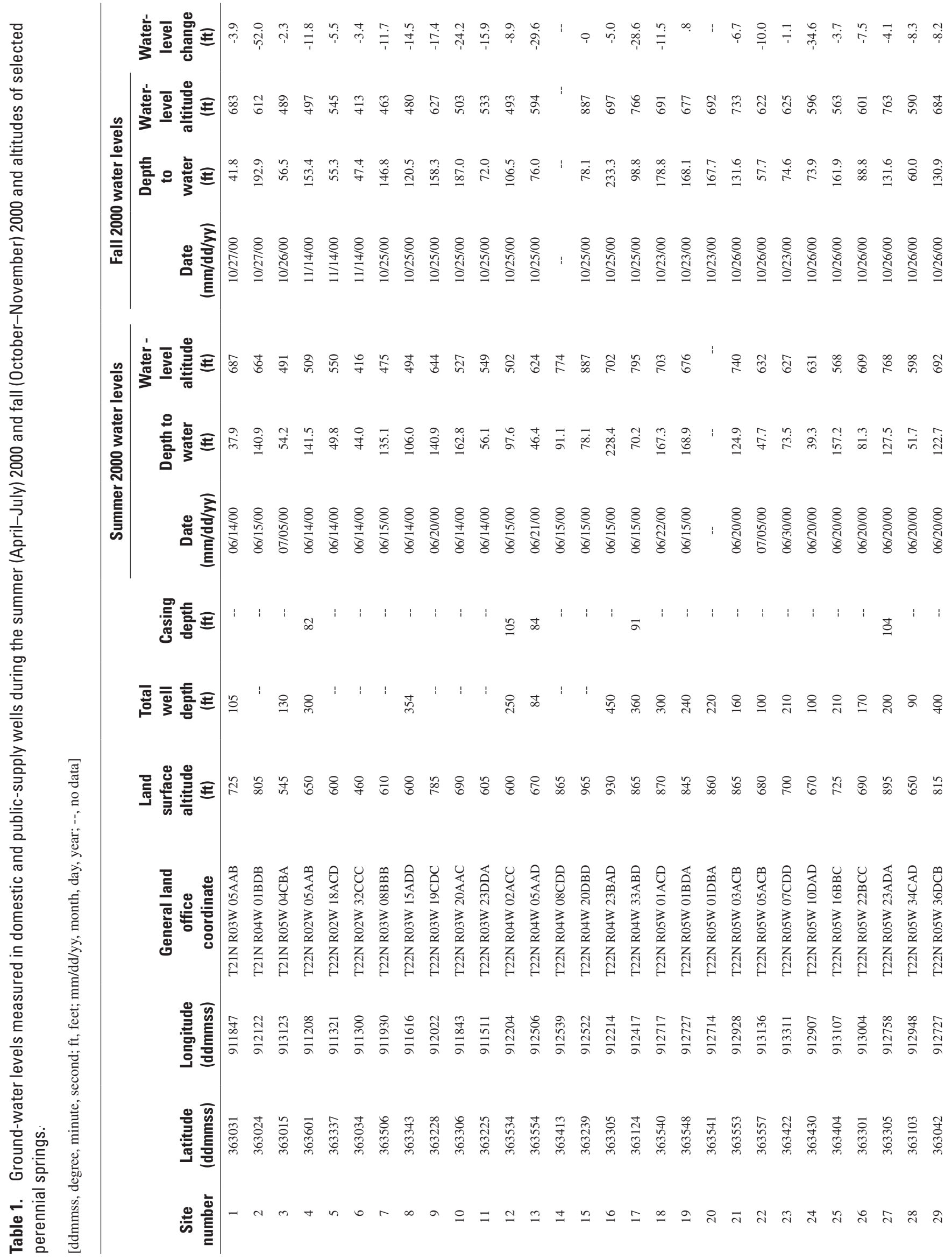




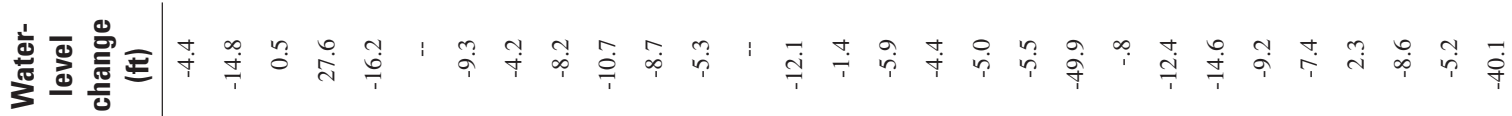

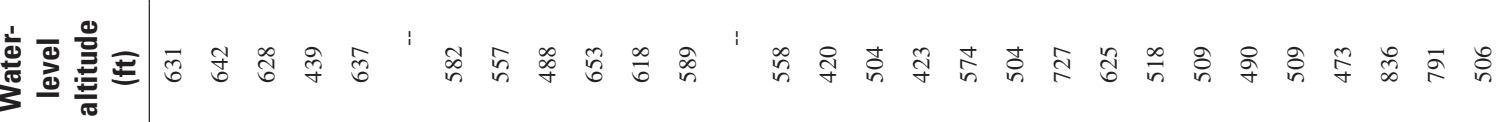
言

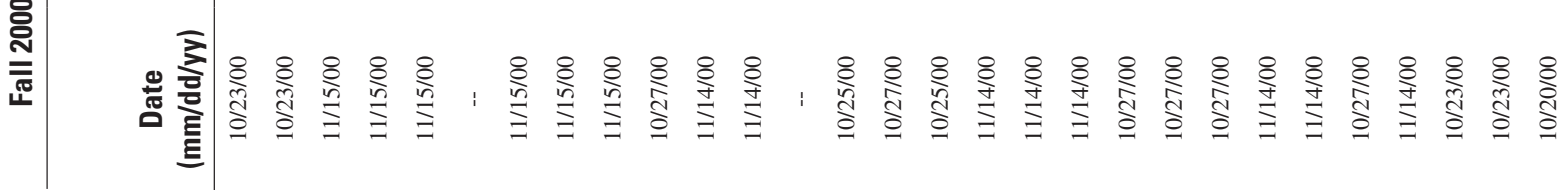

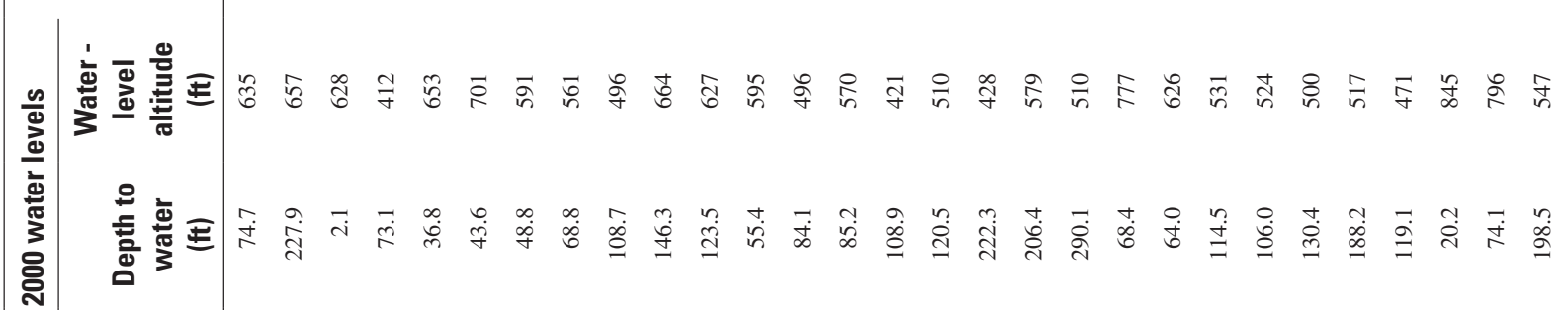

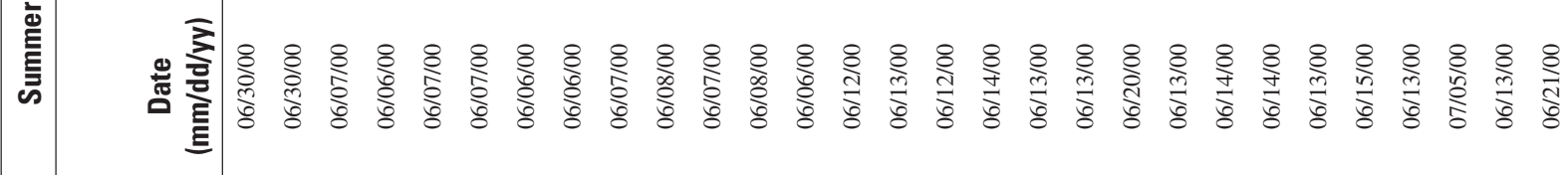
蛋

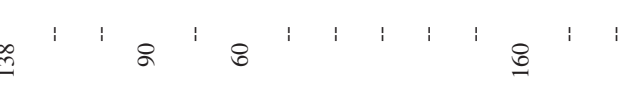

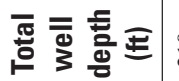
每 ‘

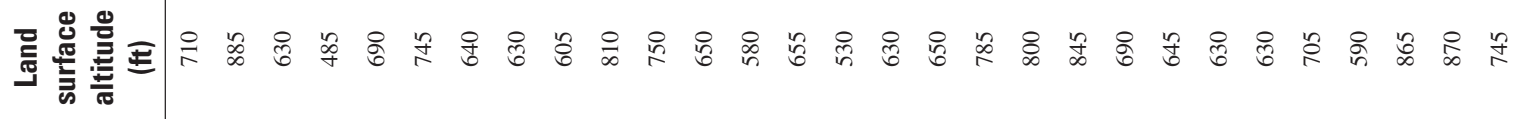
焉

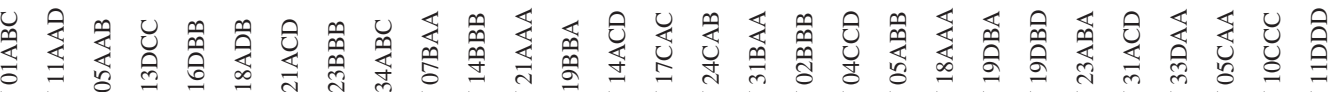

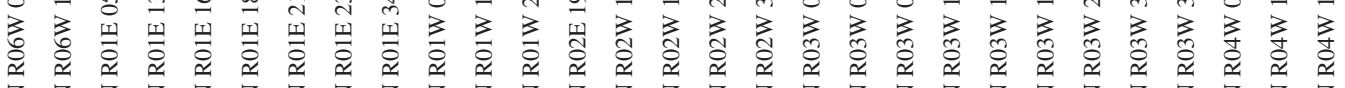

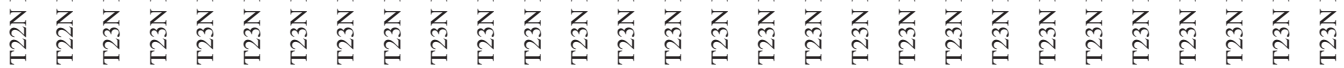

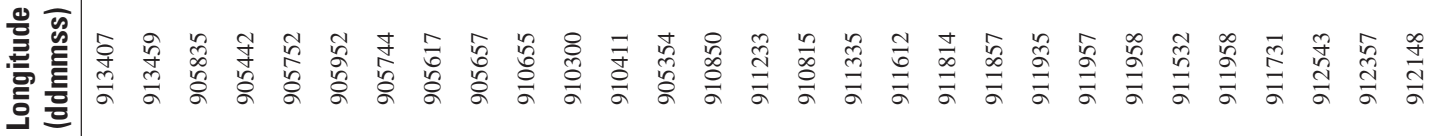

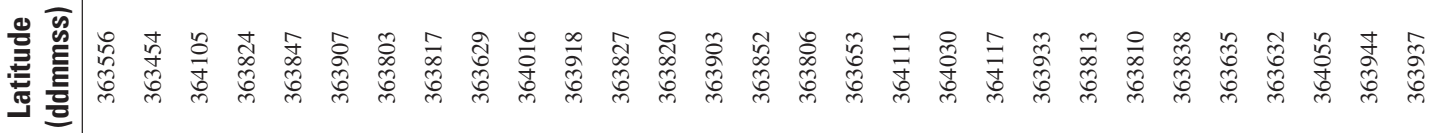

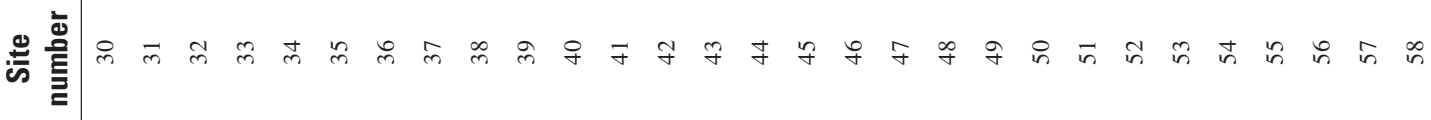




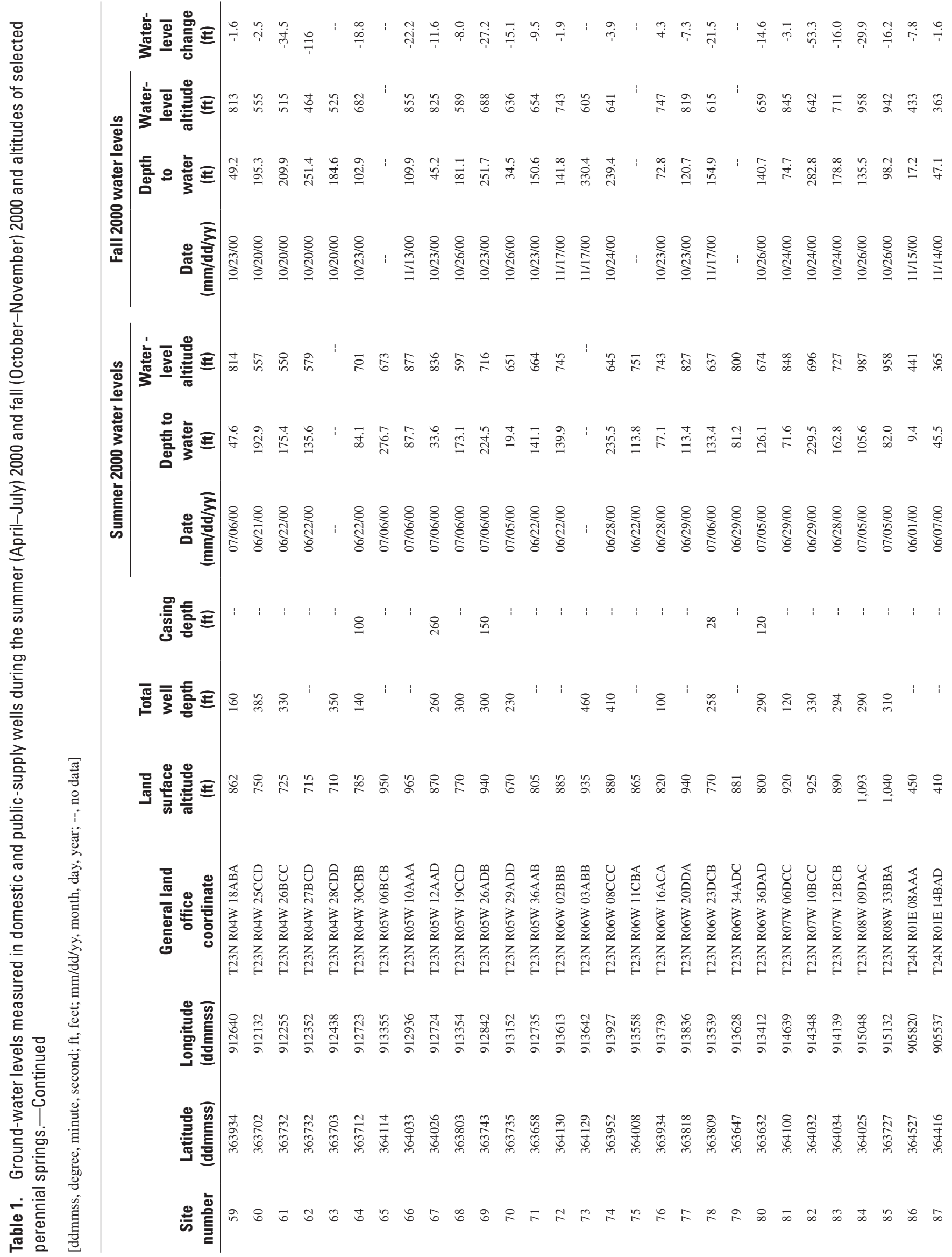




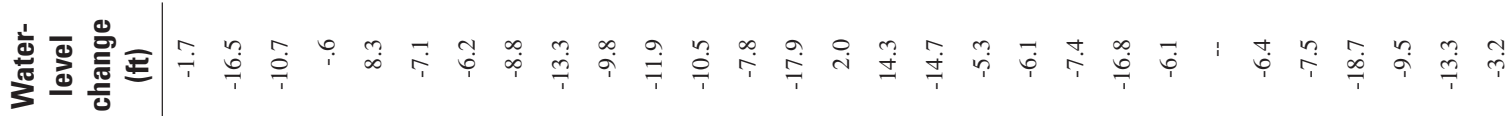

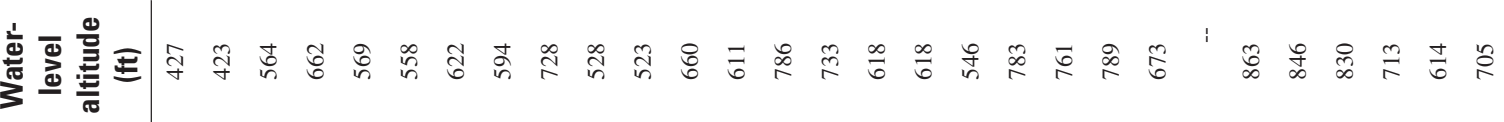

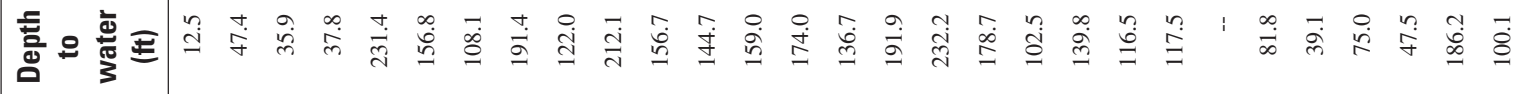

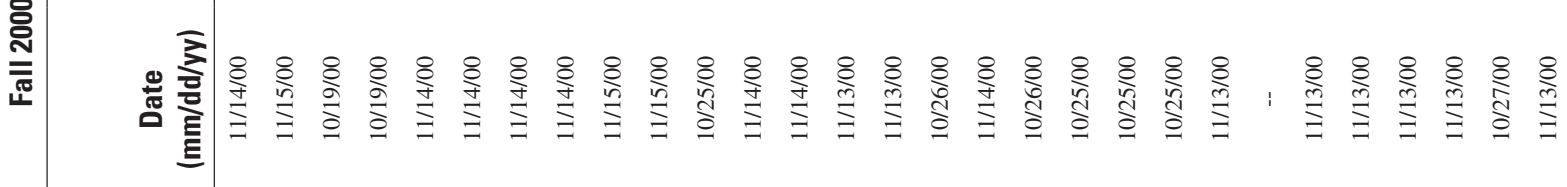

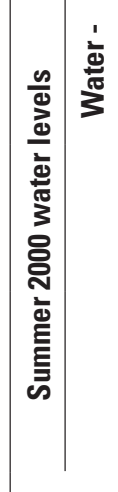
迹

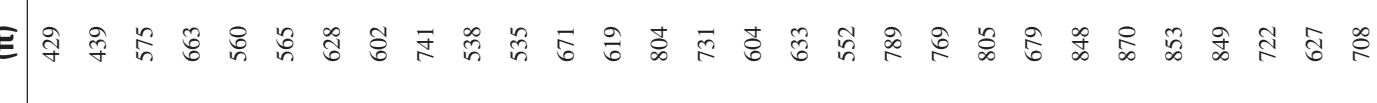

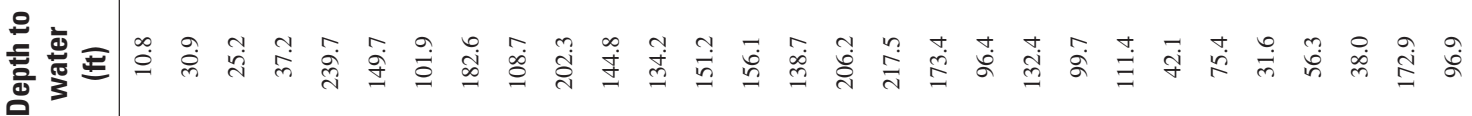

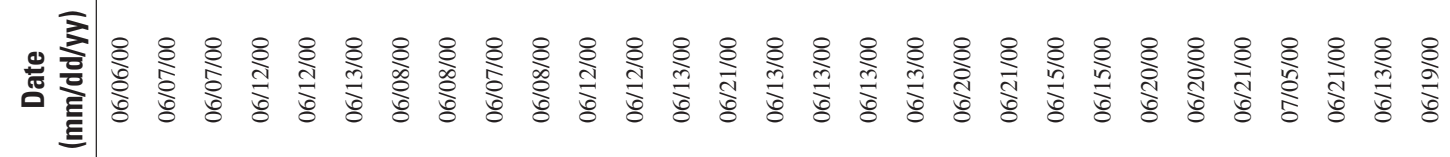

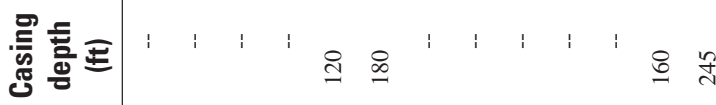

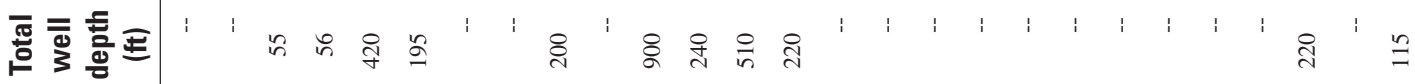

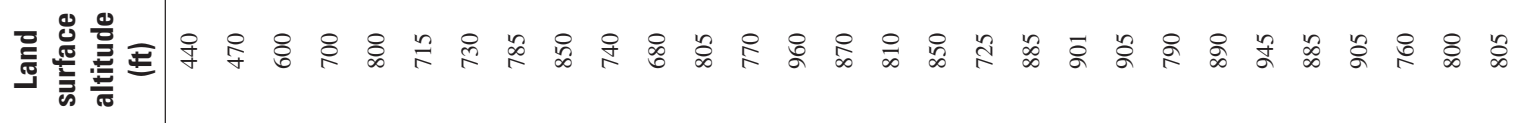
焉

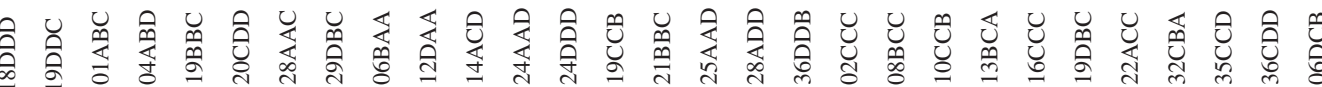

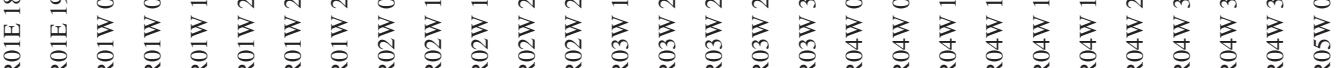

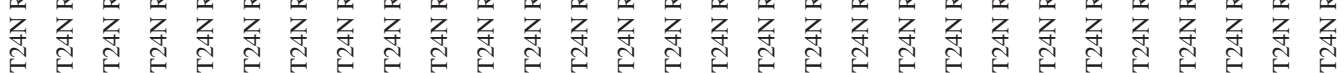

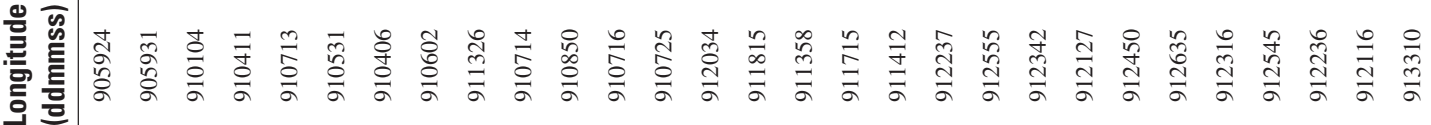

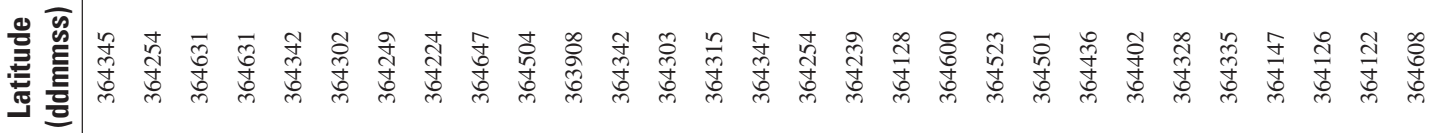

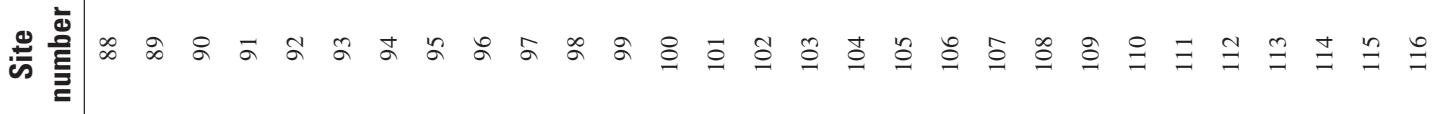




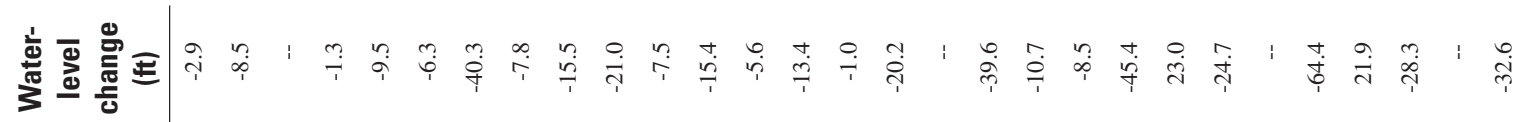

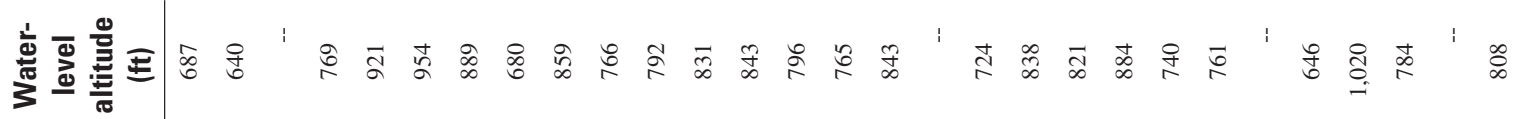

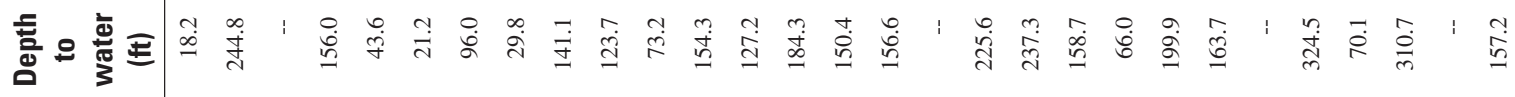

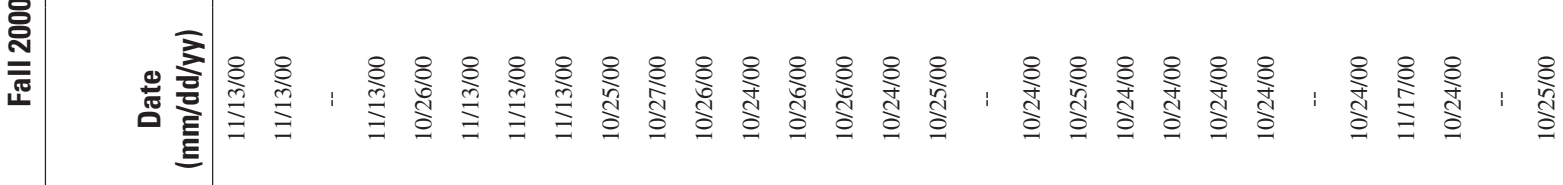

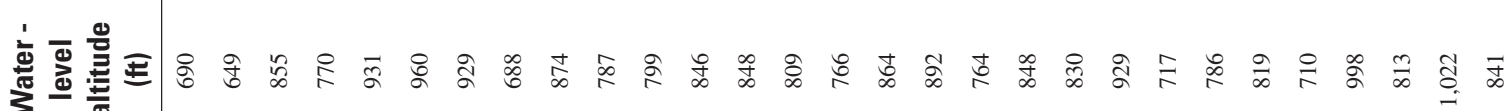

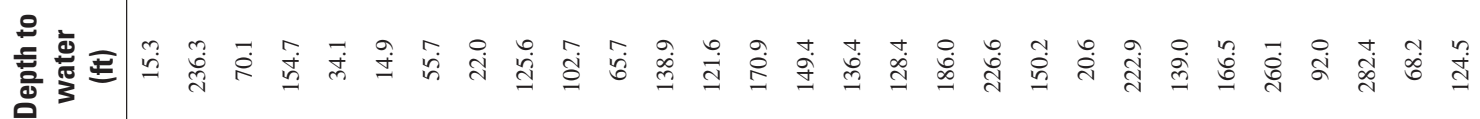

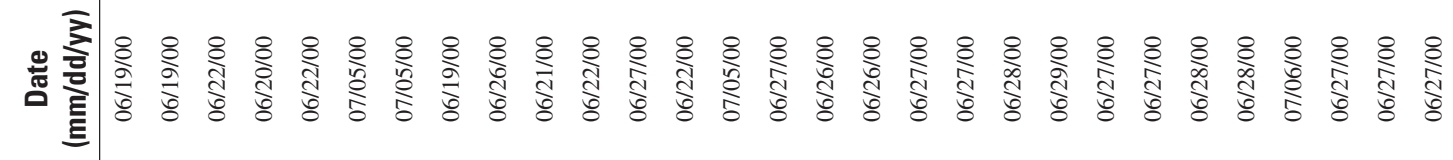

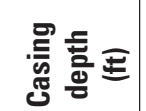

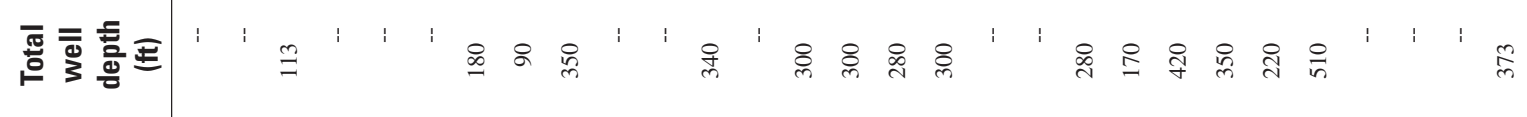

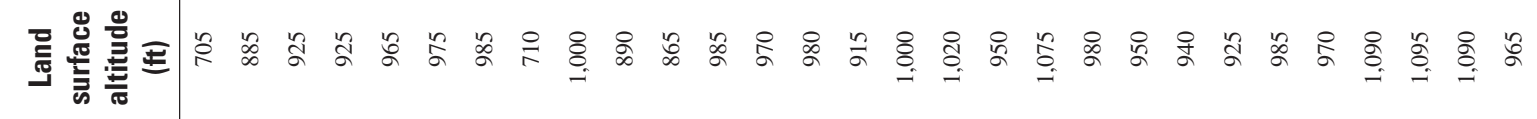

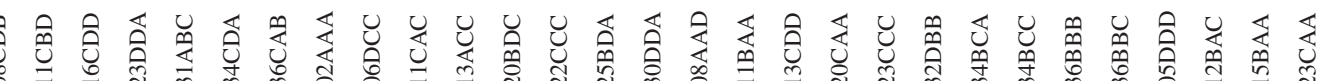

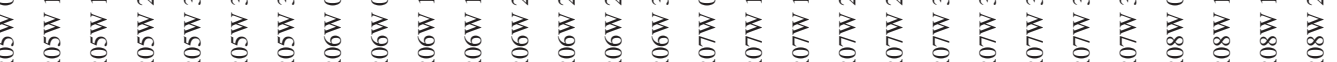

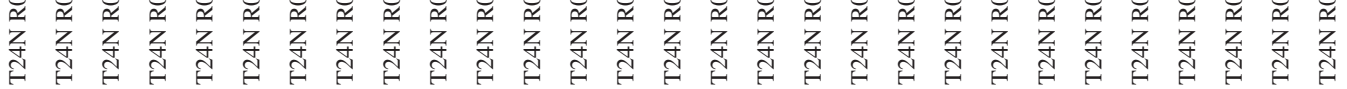

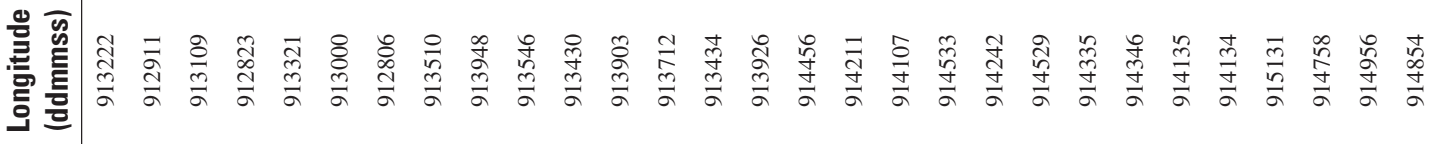

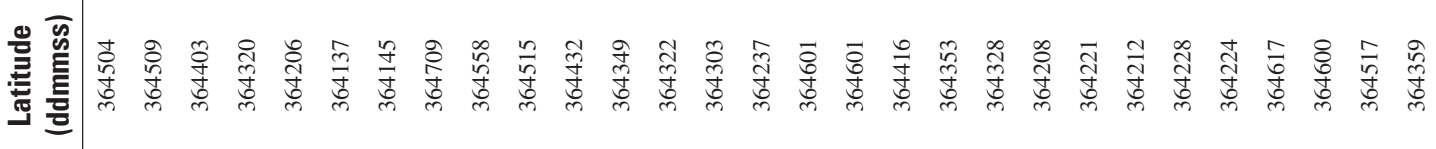

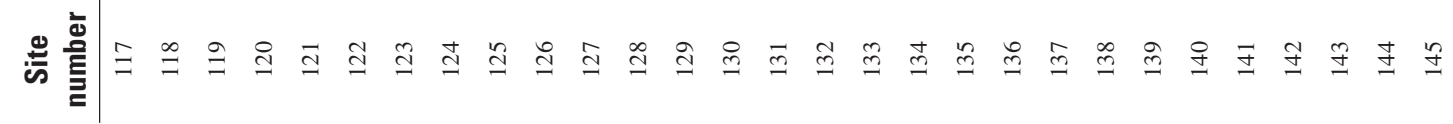




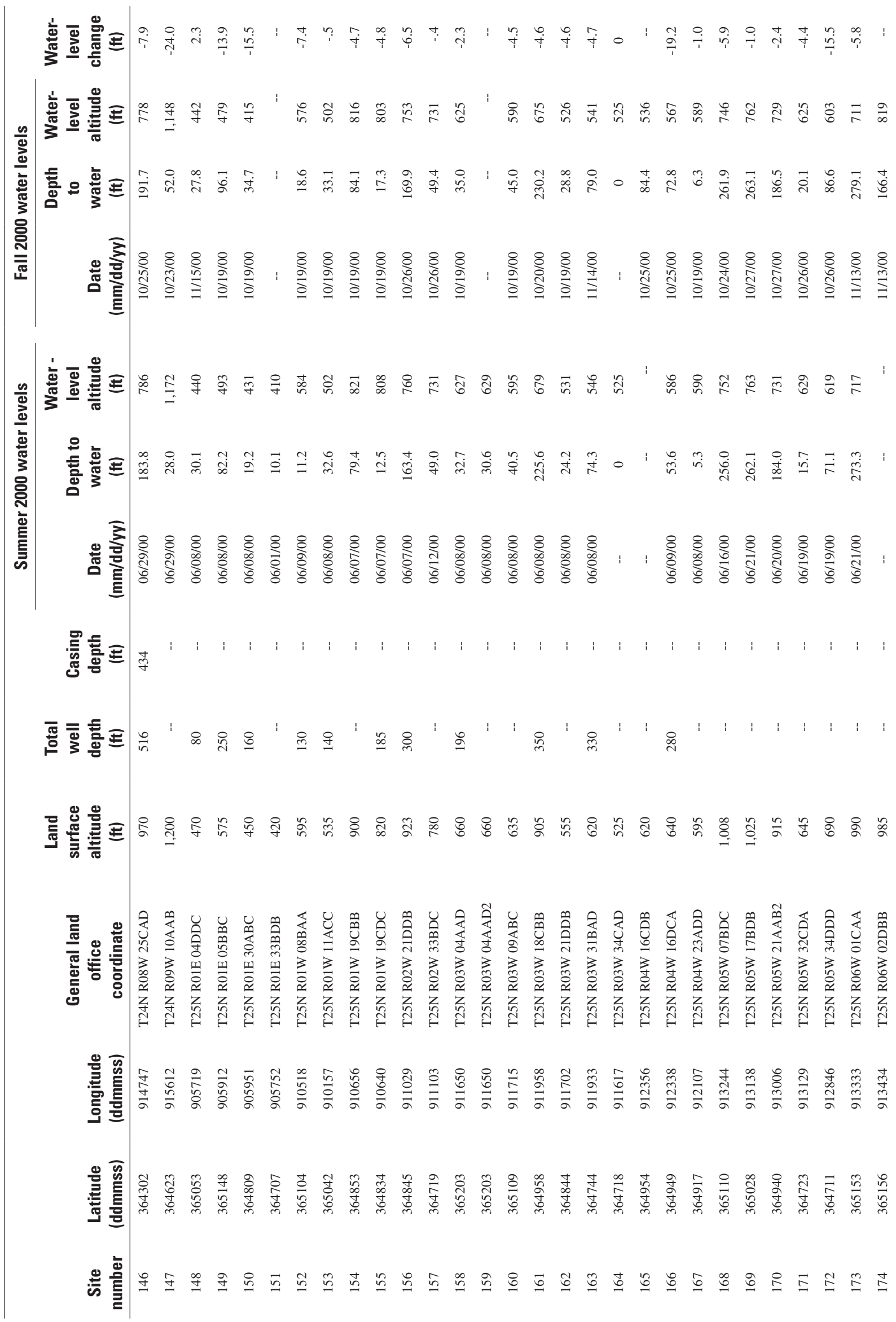




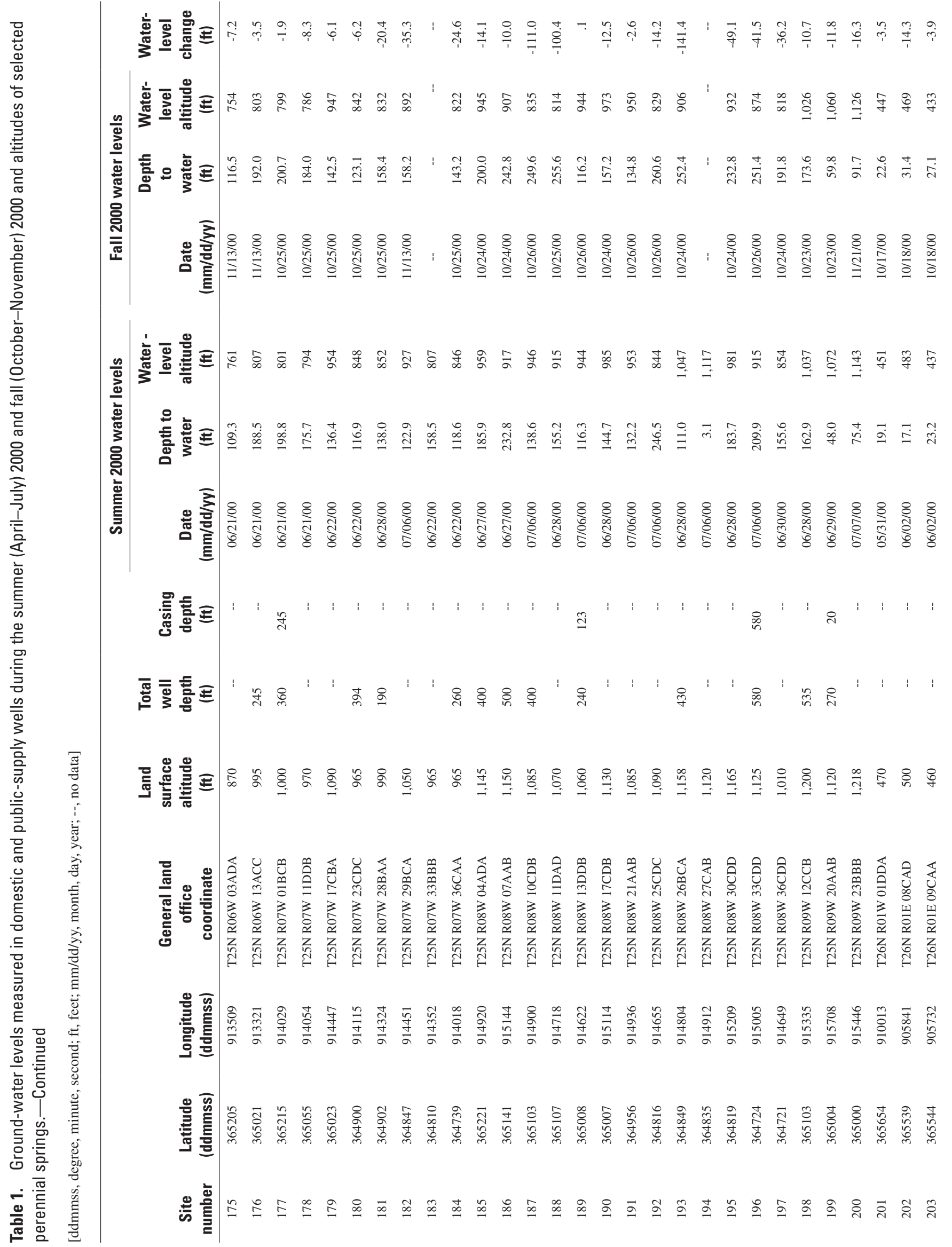




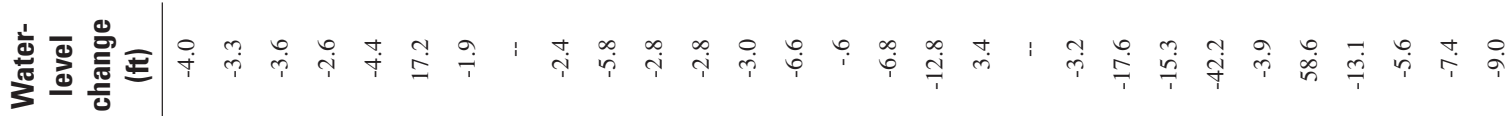

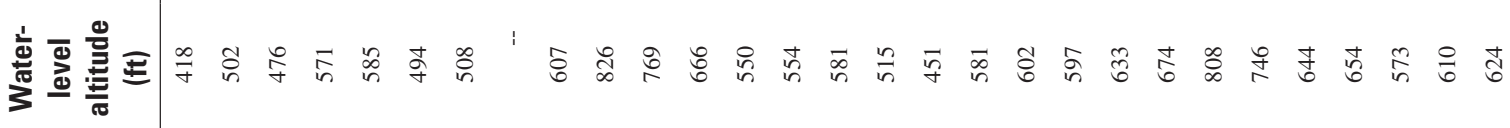

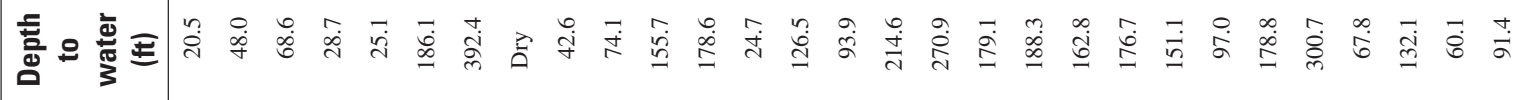

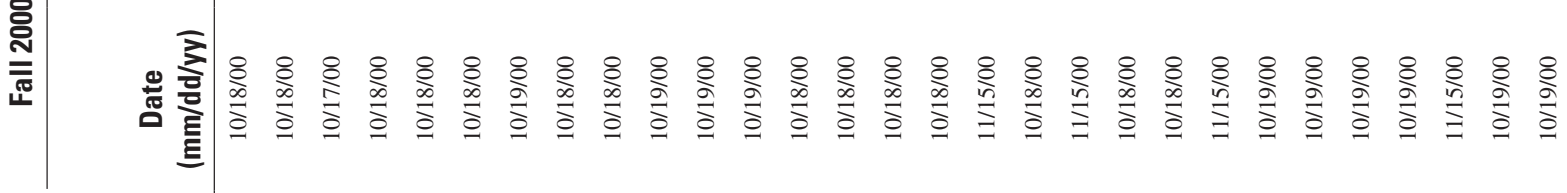

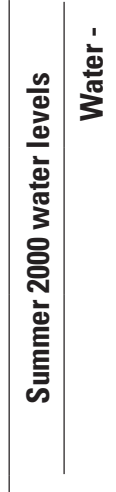

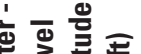

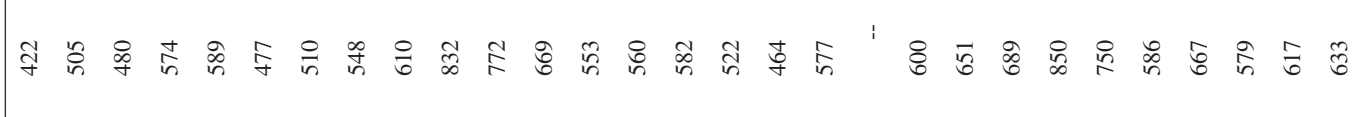

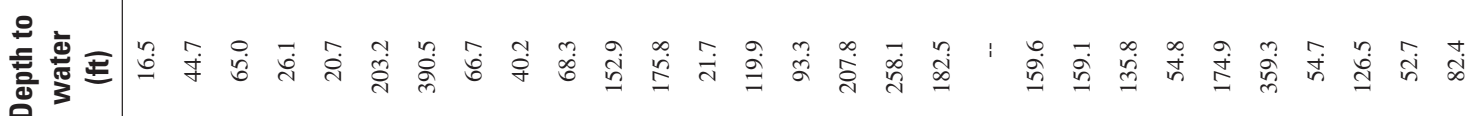

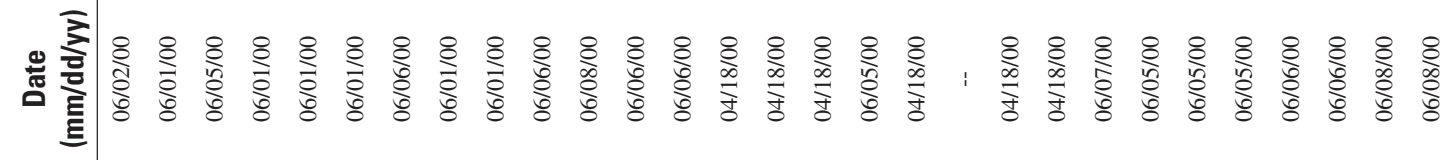

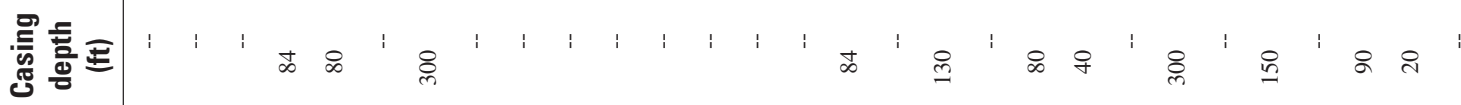

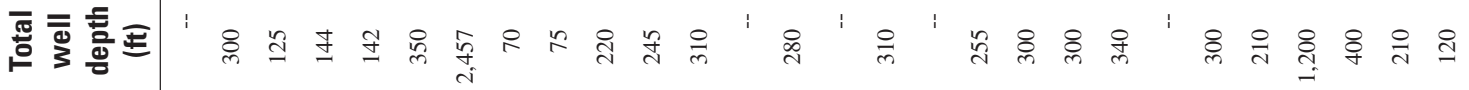

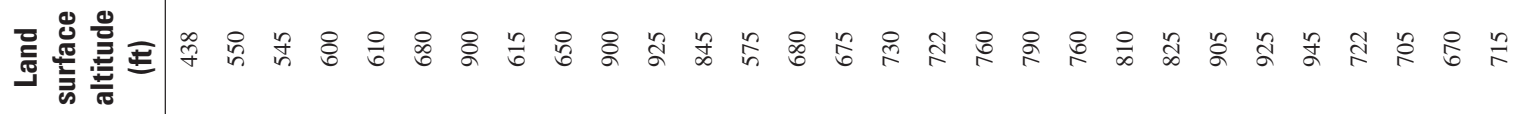

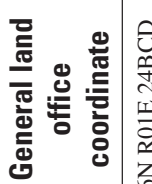

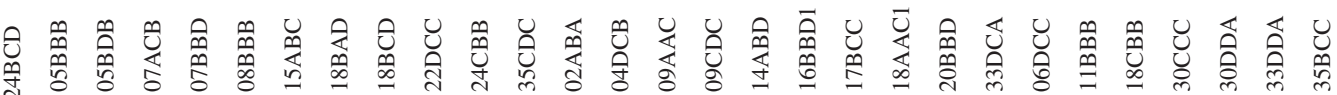

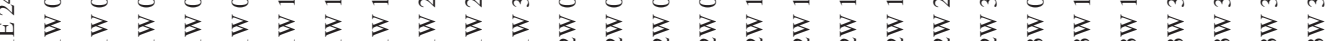

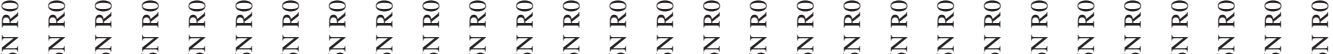

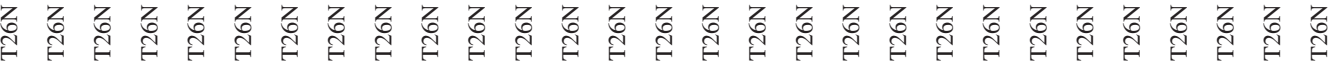

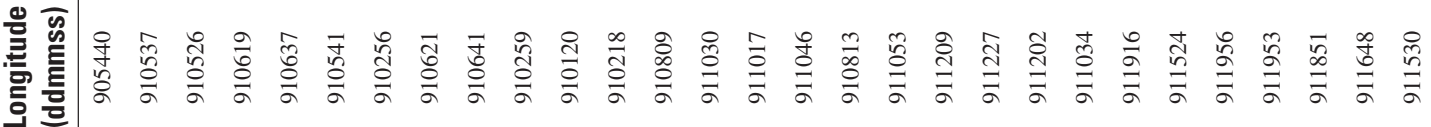

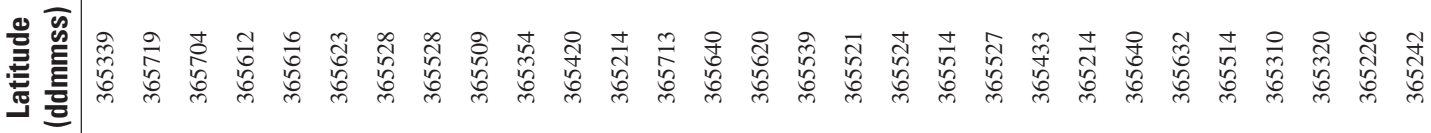

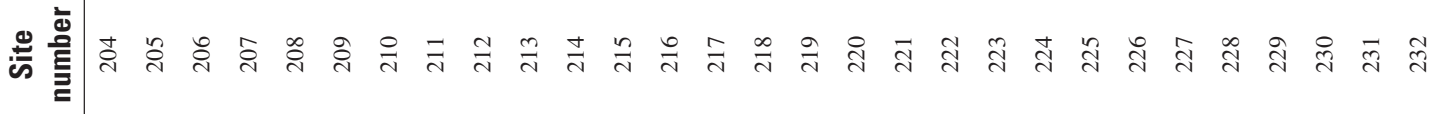




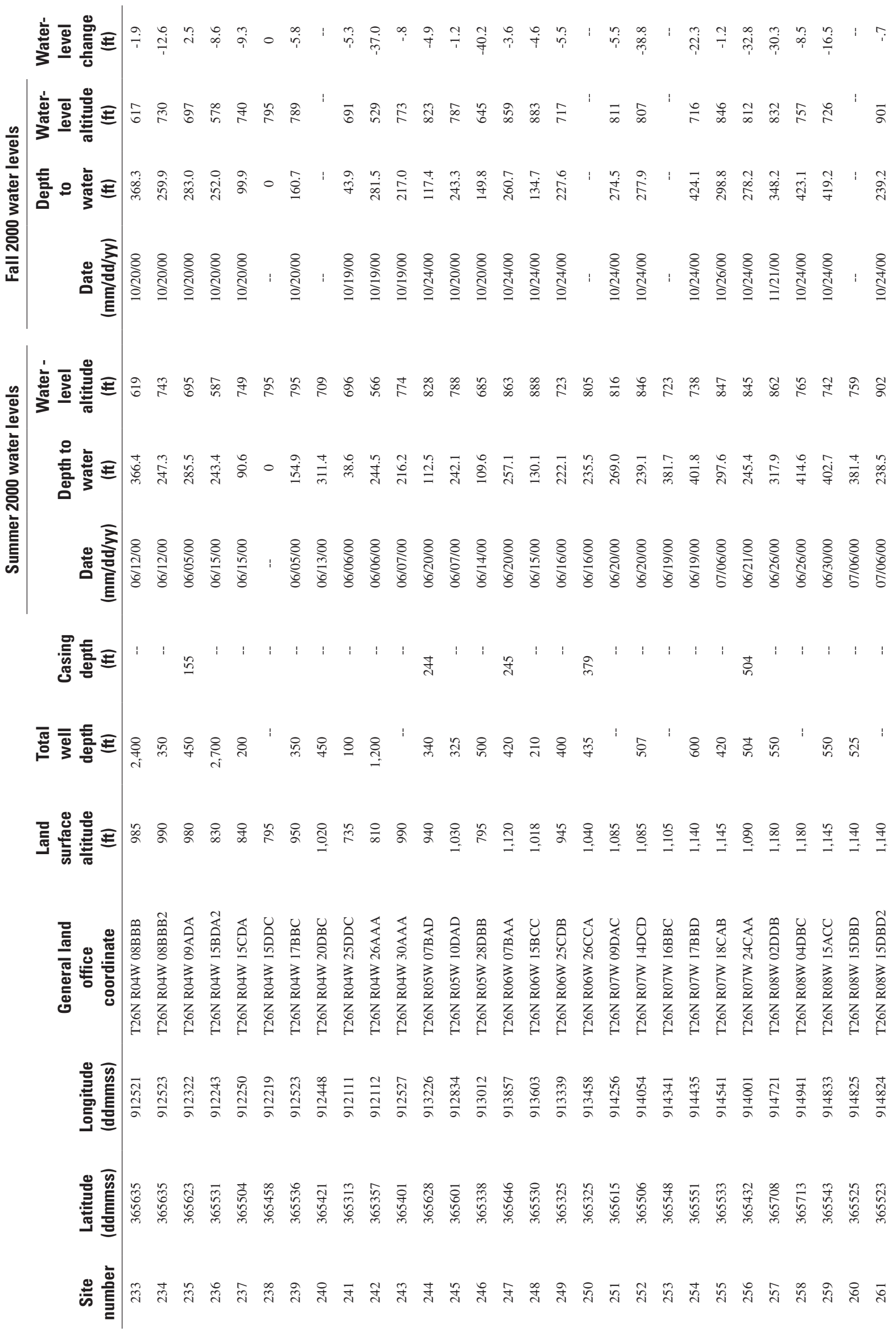




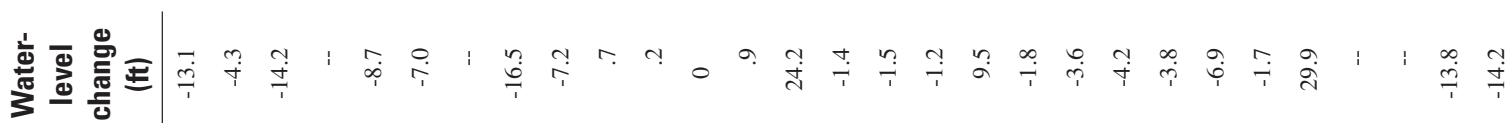

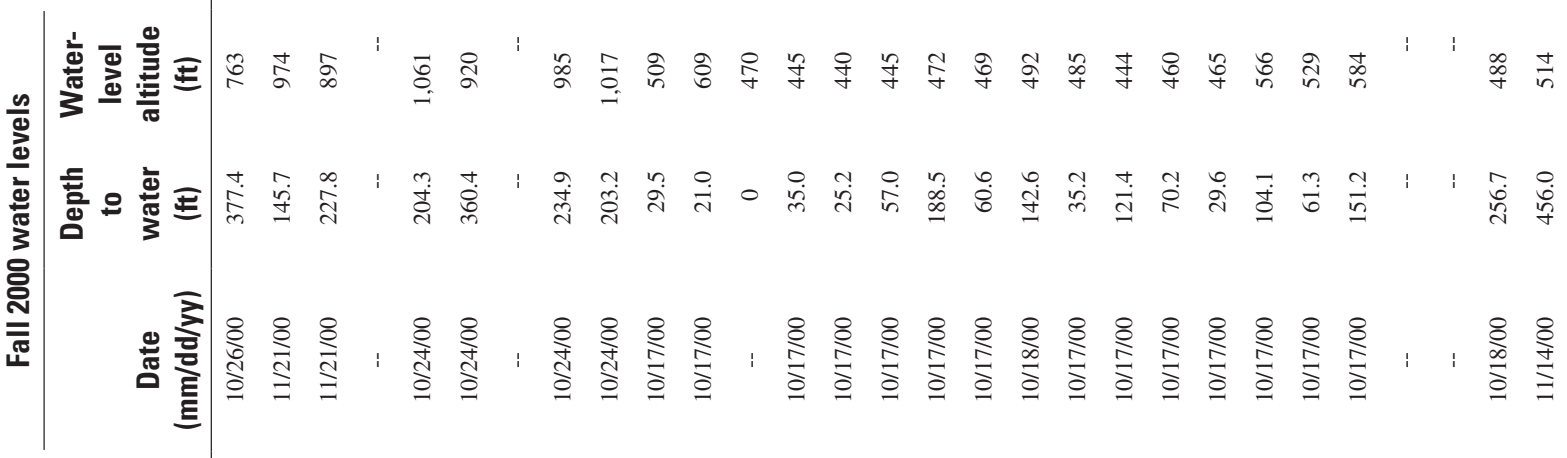

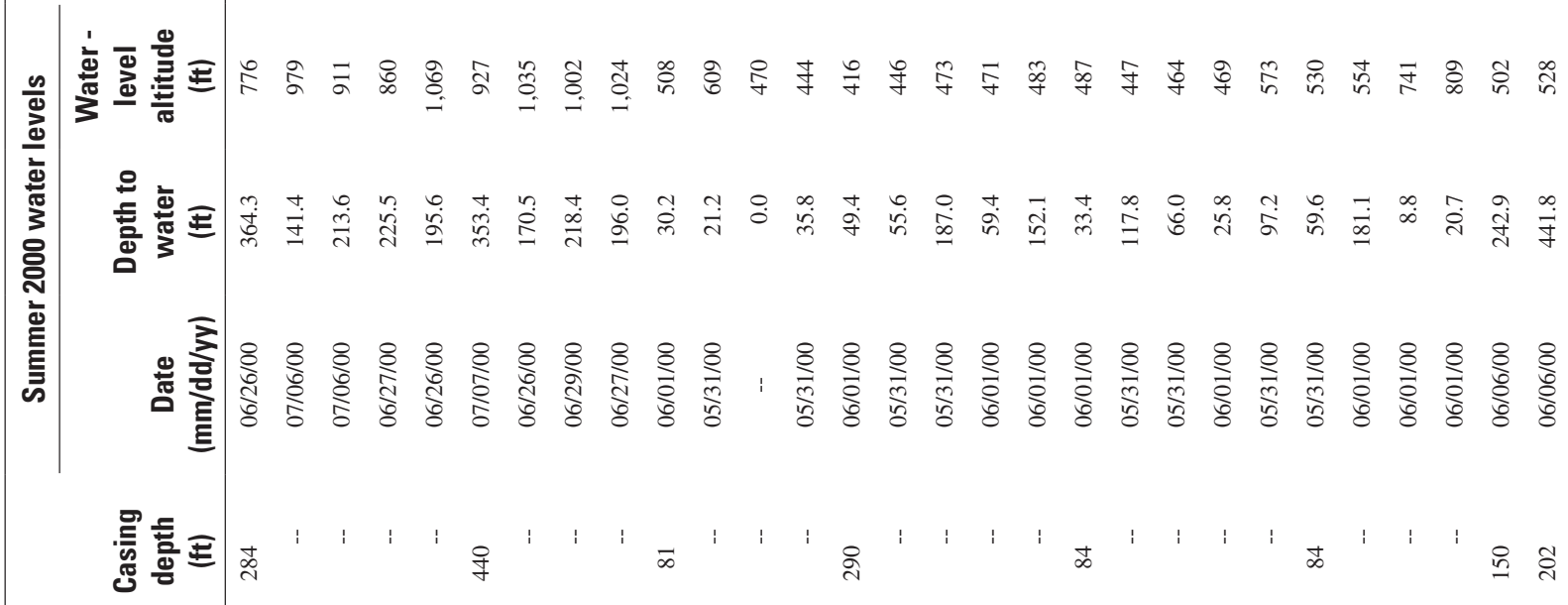

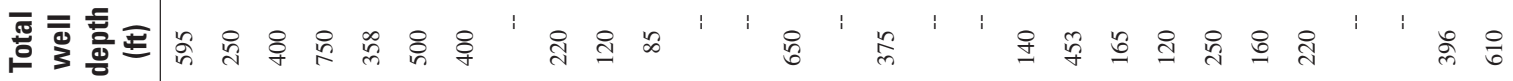

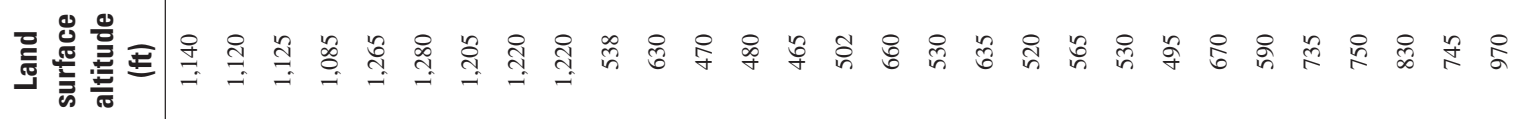

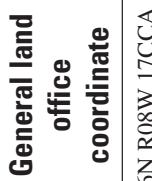

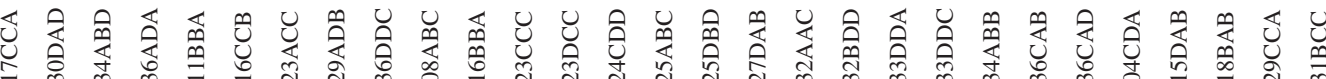

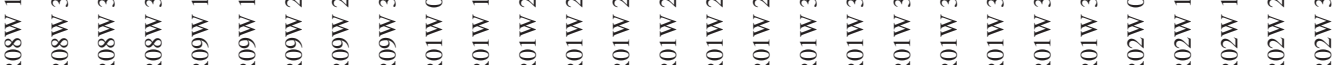

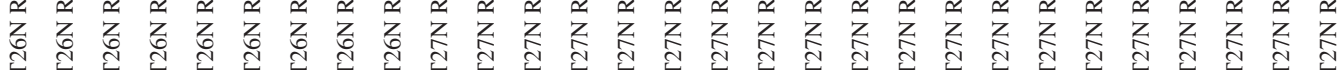

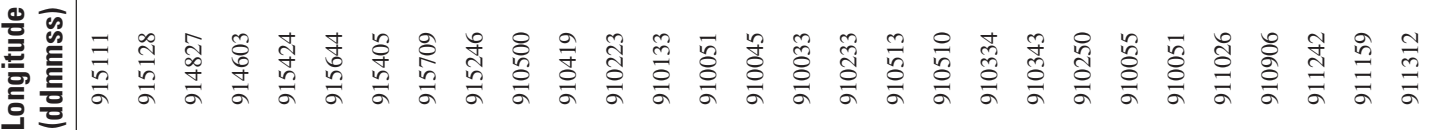

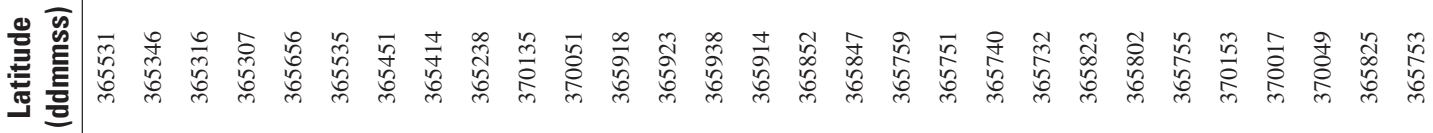

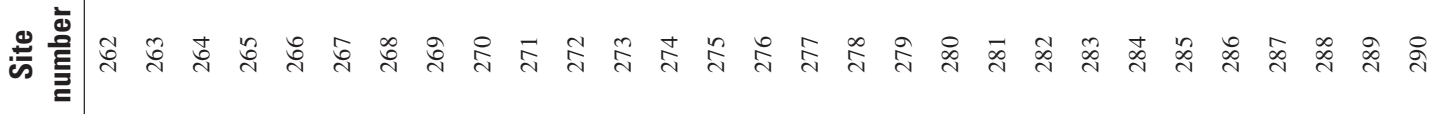




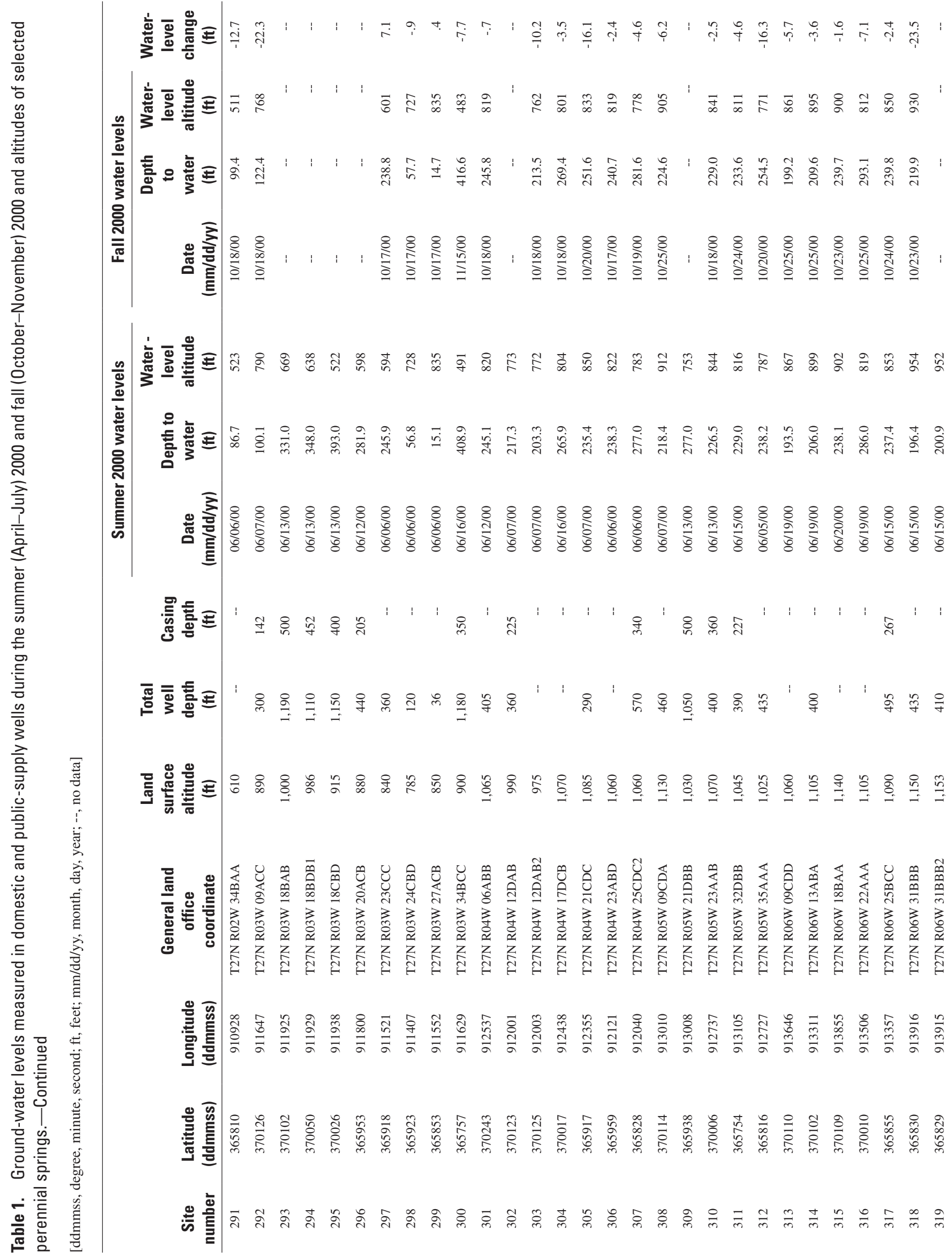




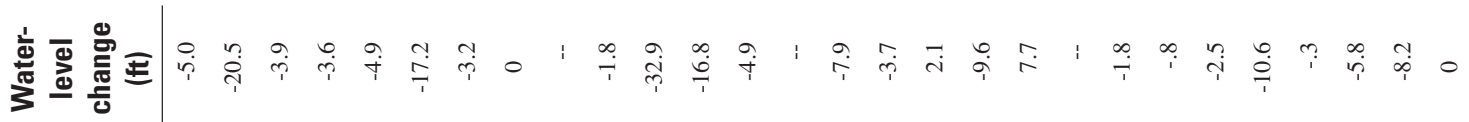

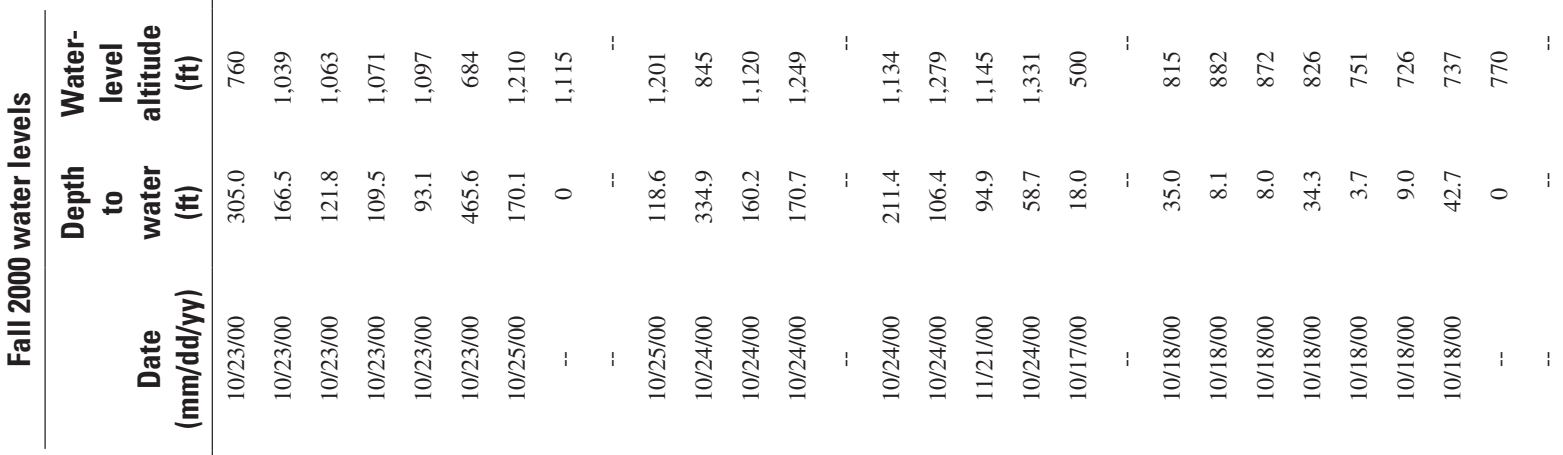

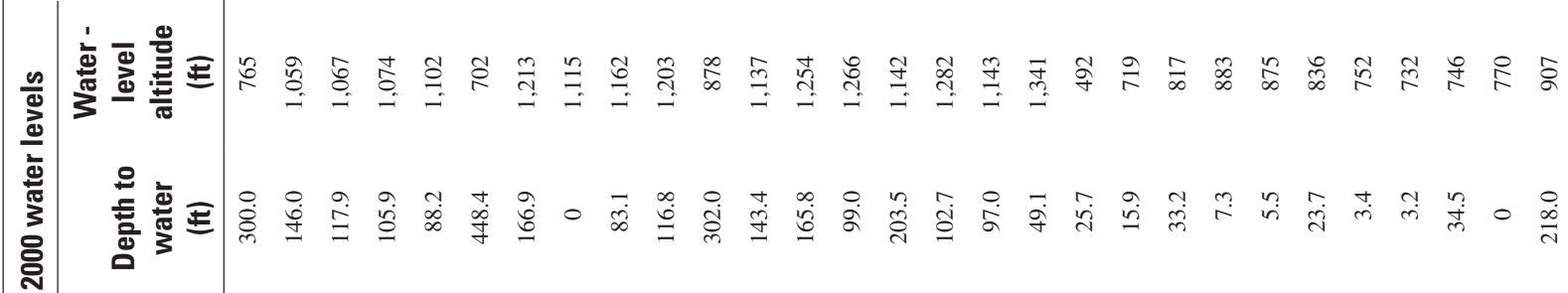

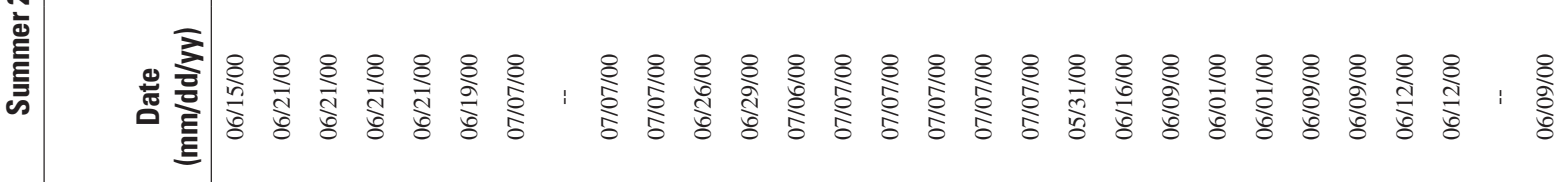
蛋

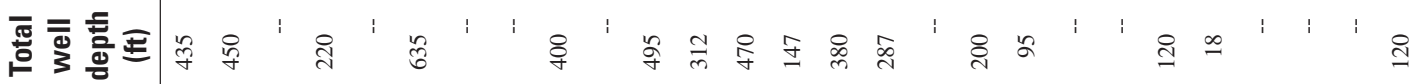

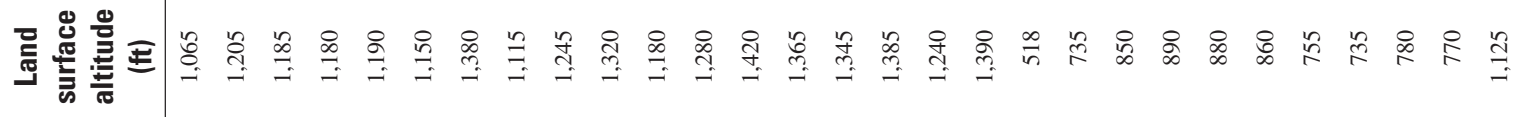
焉

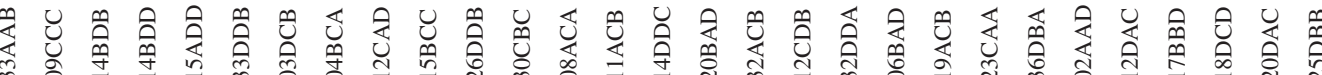

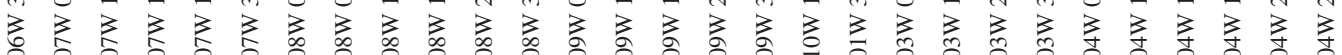

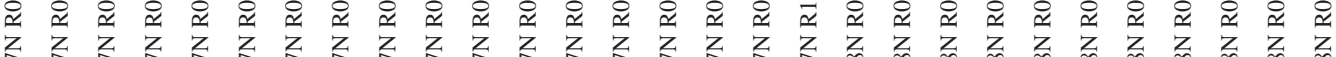

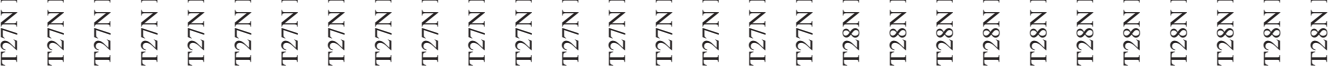

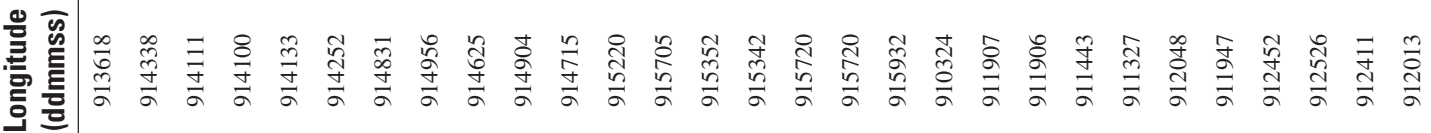

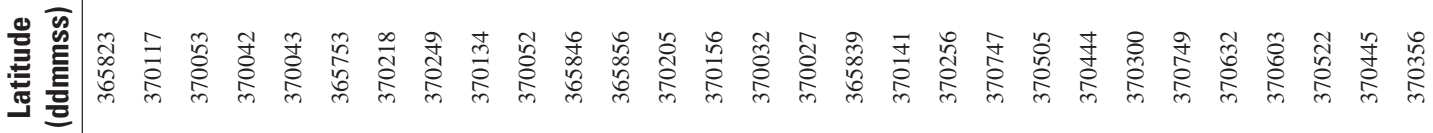

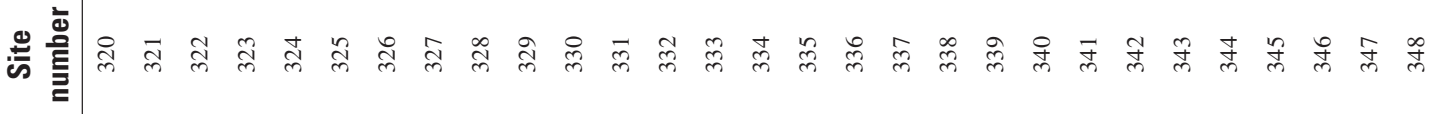




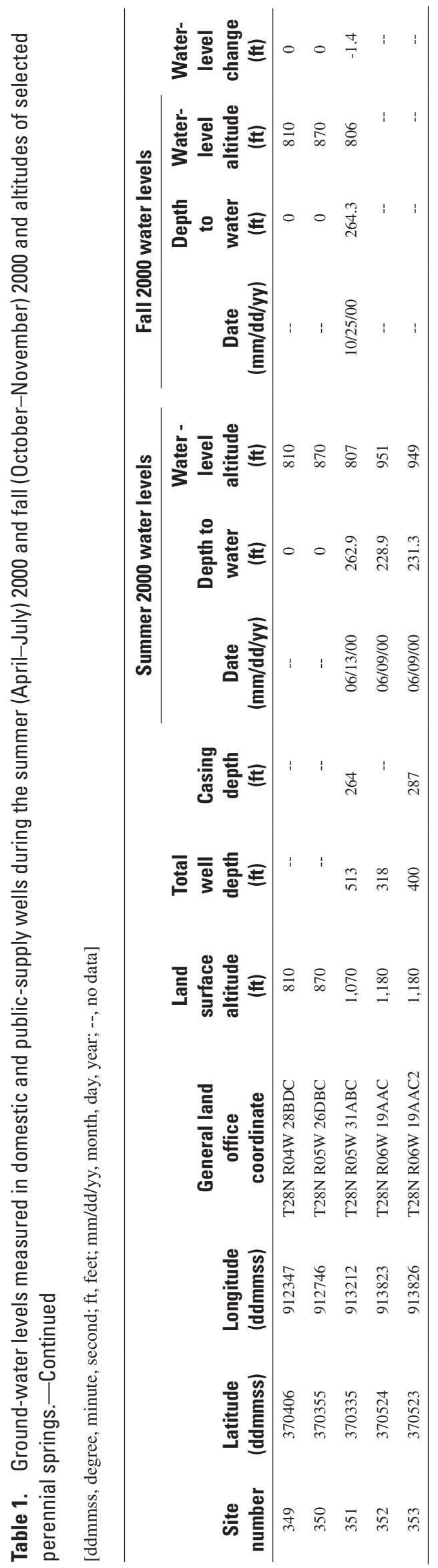


Table 2. Annual departure from normal precipitation and annual mean discharge data for Big Spring, water years 1922 through 2004.

$\left[\mathrm{ft}^{3} / \mathrm{s}\right.$, cubic feet per second]

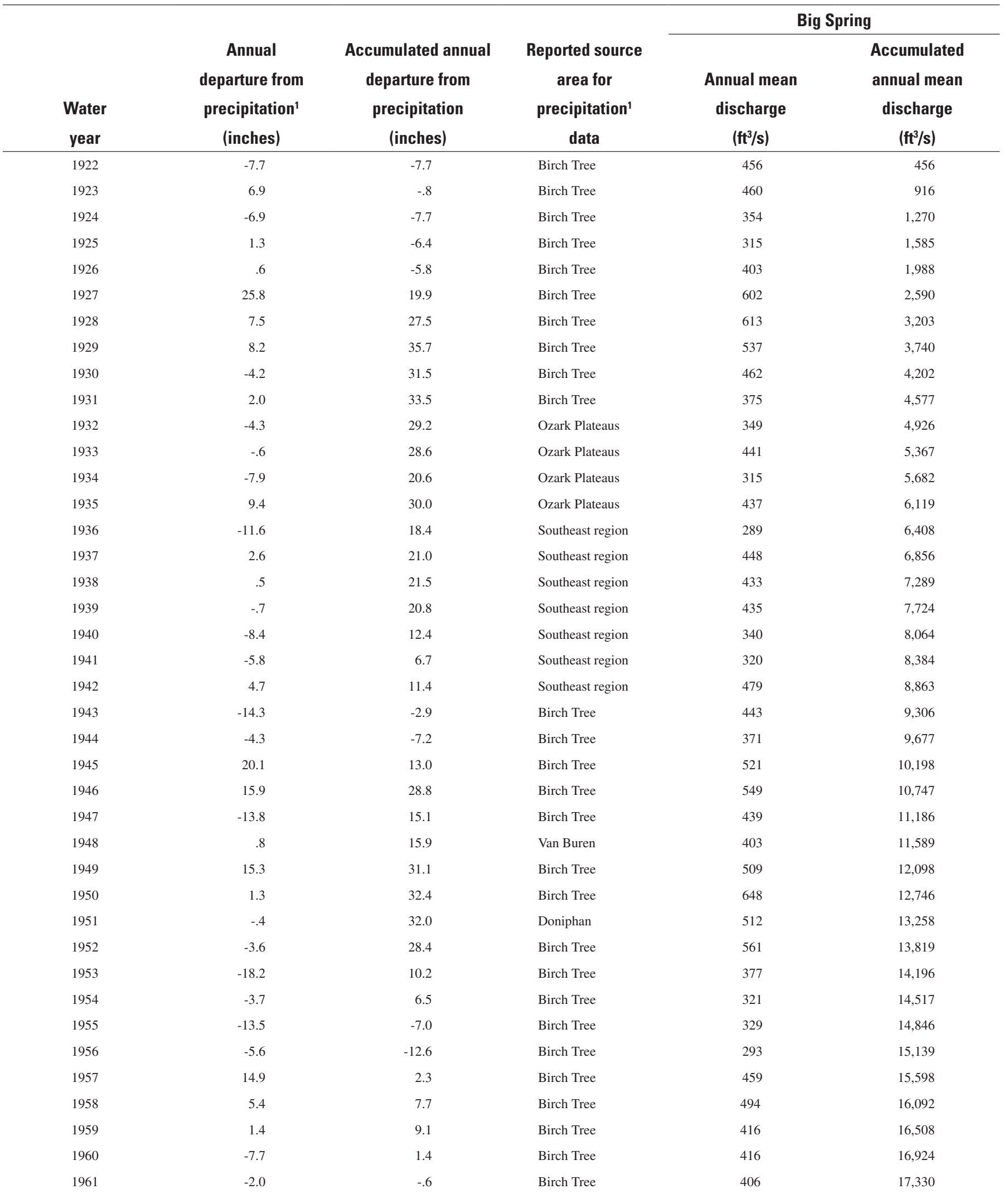


Table 2. Annual departure from normal precipitation and annual mean discharge data for Big Spring, water years 1922 through 2004.-Continued

$\left[\mathrm{ft}^{3} / \mathrm{s}\right.$, cubic feet per second]

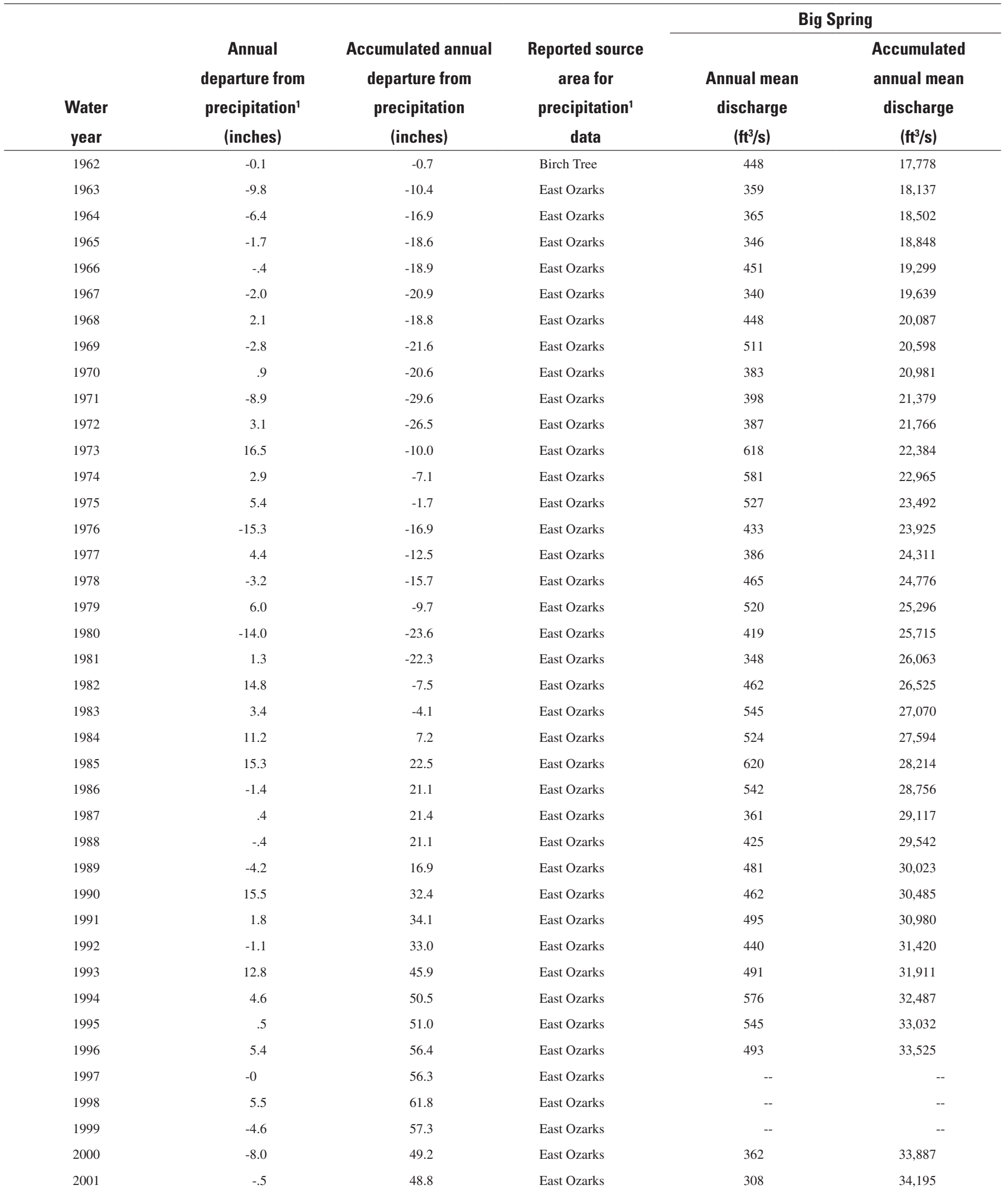


Table 2. Annual departure from normal precipitation and annual mean discharge data for Big Spring, water years 1922 through 2004. - Continued

$\left[\mathrm{ft}^{3} / \mathrm{s}\right.$, cubic feet per second]

\begin{tabular}{|c|c|c|c|c|c|}
\hline \multirow[b]{2}{*}{$\begin{array}{c}\text { Water } \\
\text { year }\end{array}$} & \multirow[b]{2}{*}{$\begin{array}{l}\text { Annual } \\
\text { departure from } \\
\text { precipitation' } \\
\text { (inches) }\end{array}$} & \multirow[b]{2}{*}{$\begin{array}{l}\text { Accumulated annual } \\
\text { departure from } \\
\text { precipitation } \\
\text { (inches) }\end{array}$} & \multirow[b]{2}{*}{$\begin{array}{l}\text { Reported source } \\
\text { area for } \\
\text { precipitation } \\
\text { data }\end{array}$} & \multicolumn{2}{|c|}{ Big Spring } \\
\hline & & & & $\begin{array}{c}\text { Annual mean } \\
\text { discharge } \\
\left(\mathrm{ft}^{3} / \mathrm{s}\right)\end{array}$ & $\begin{array}{l}\text { Accumulated } \\
\text { annual mean } \\
\text { discharge } \\
\left(\mathrm{ft}^{3} / \mathbf{s}\right)\end{array}$ \\
\hline 2002 & 9.2 & 58.0 & East Ozarks & 496 & 34,691 \\
\hline 2004 & 1.0 & 60.9 & East Ozarks & 462 & 35,516 \\
\hline
\end{tabular}

${ }^{1}$ National Oceanic and Atmospheric Administration (1922-2004). Normal precipitation calculated by National Oceanic and Atmospheric Administration for calender year. 


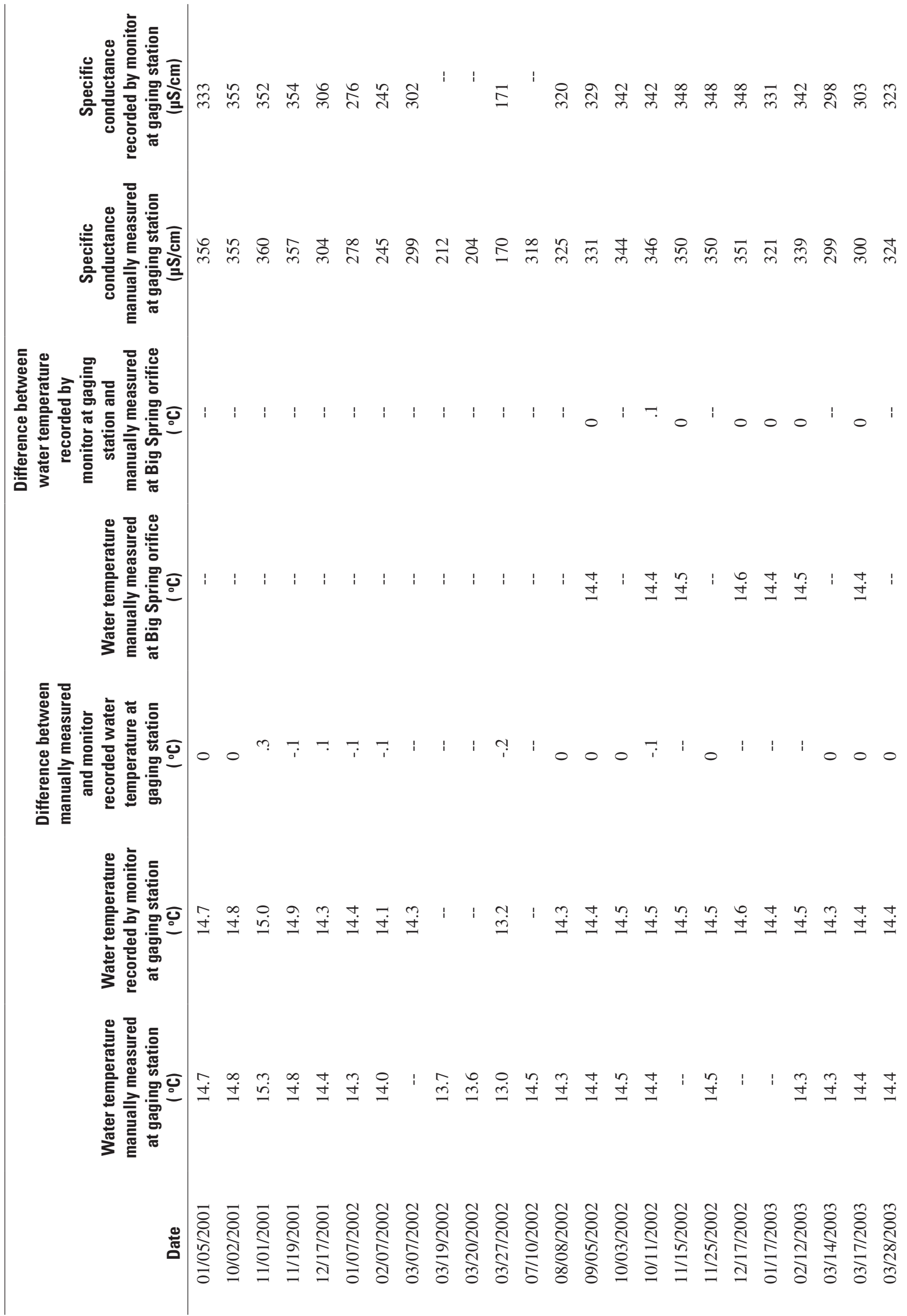



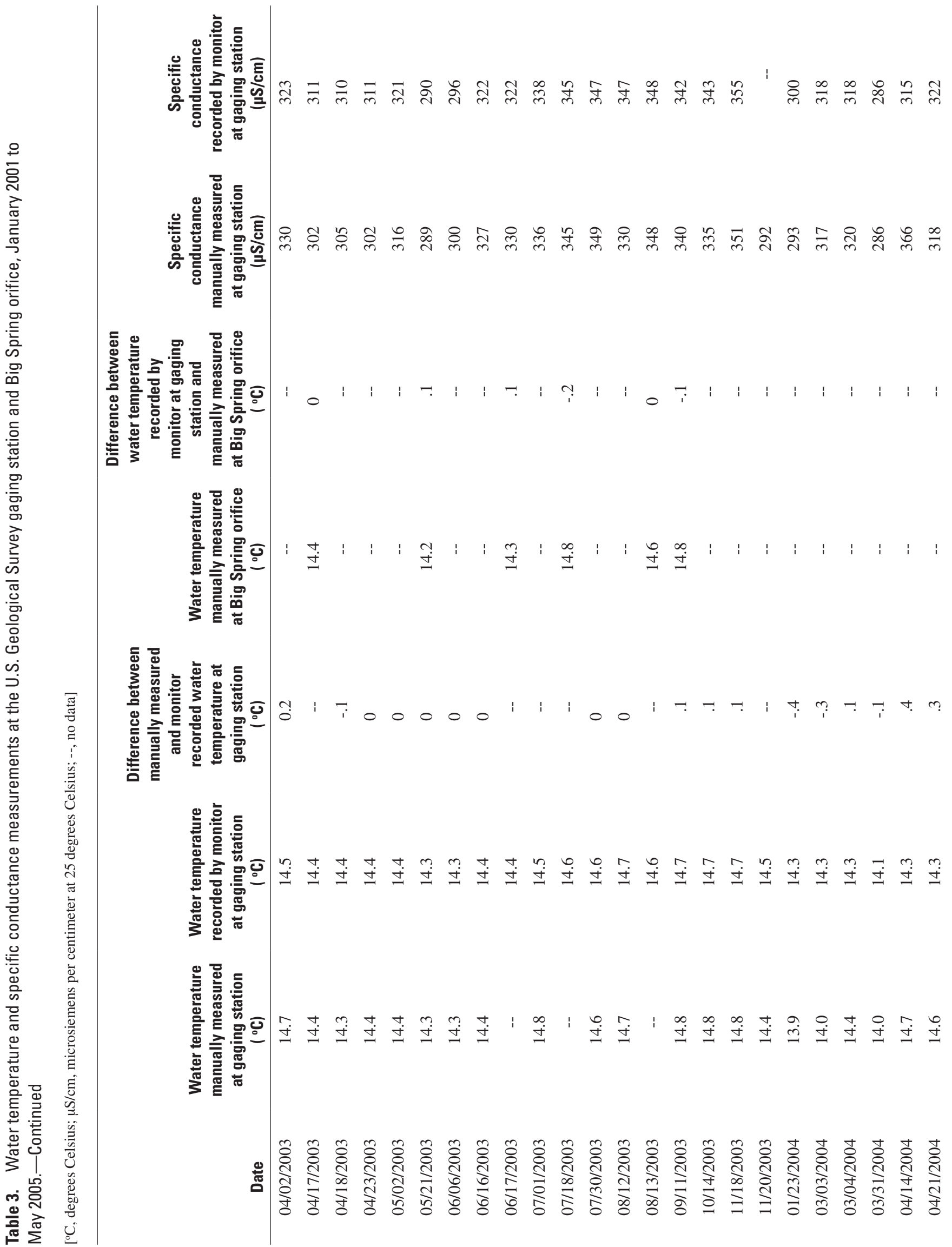

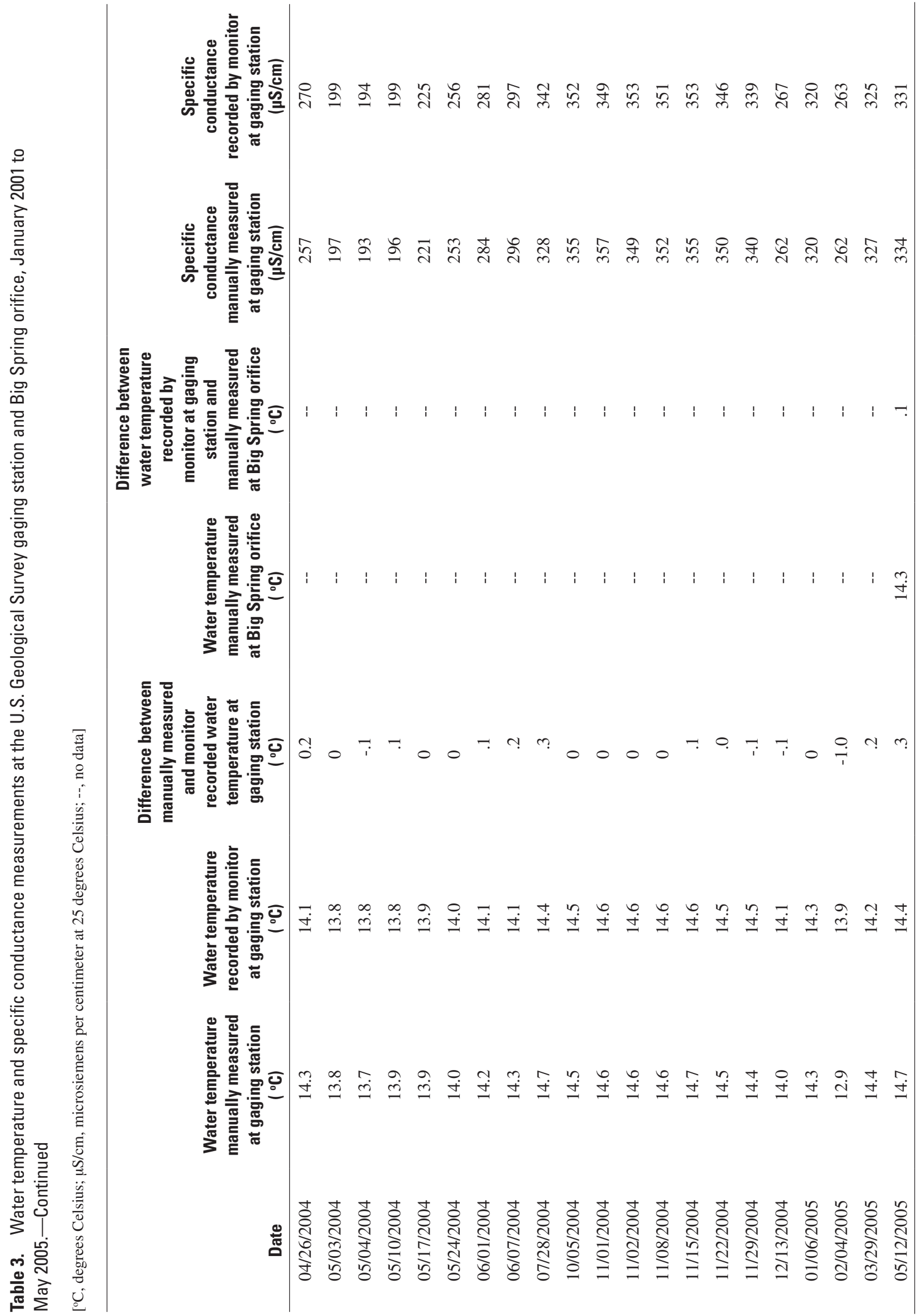


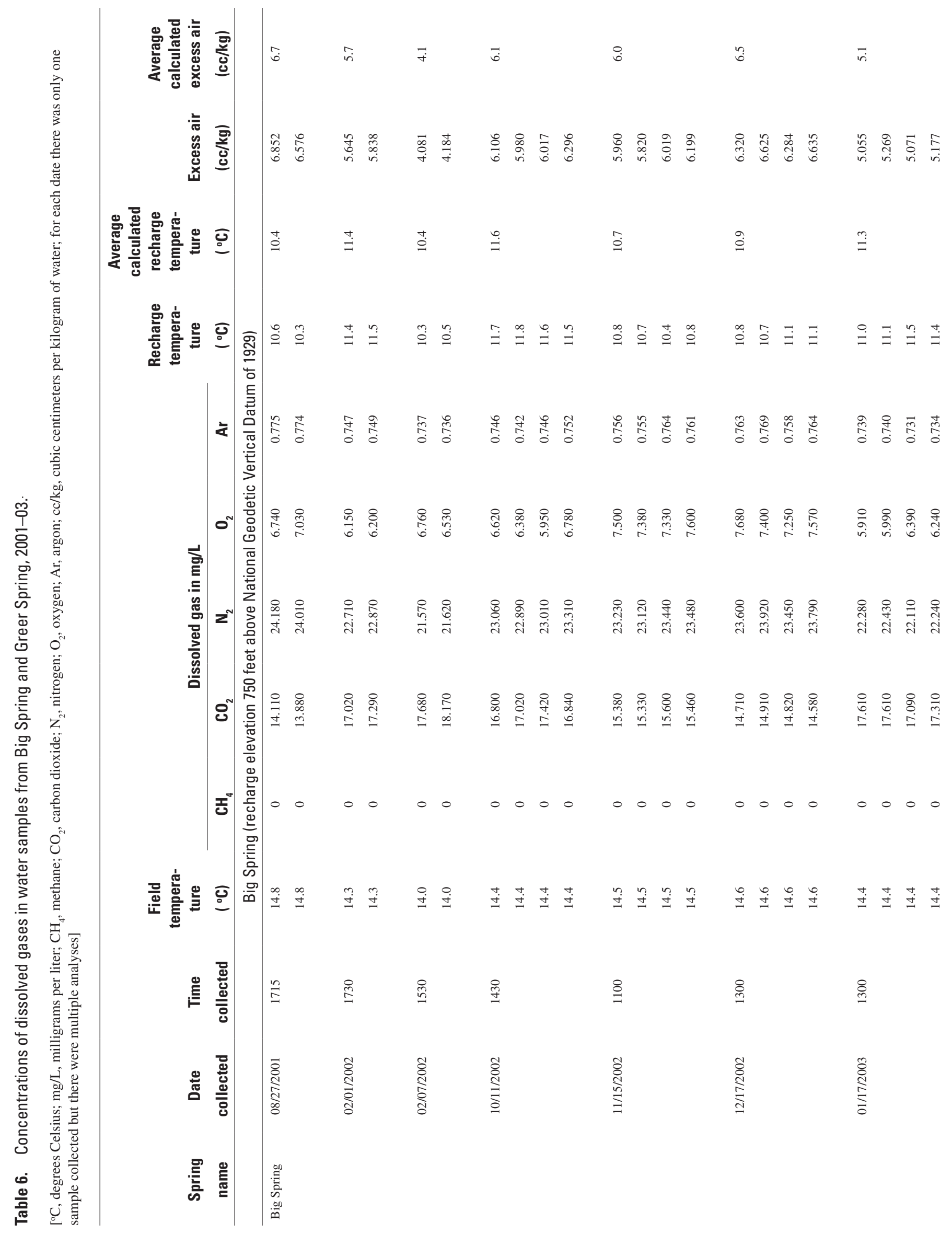




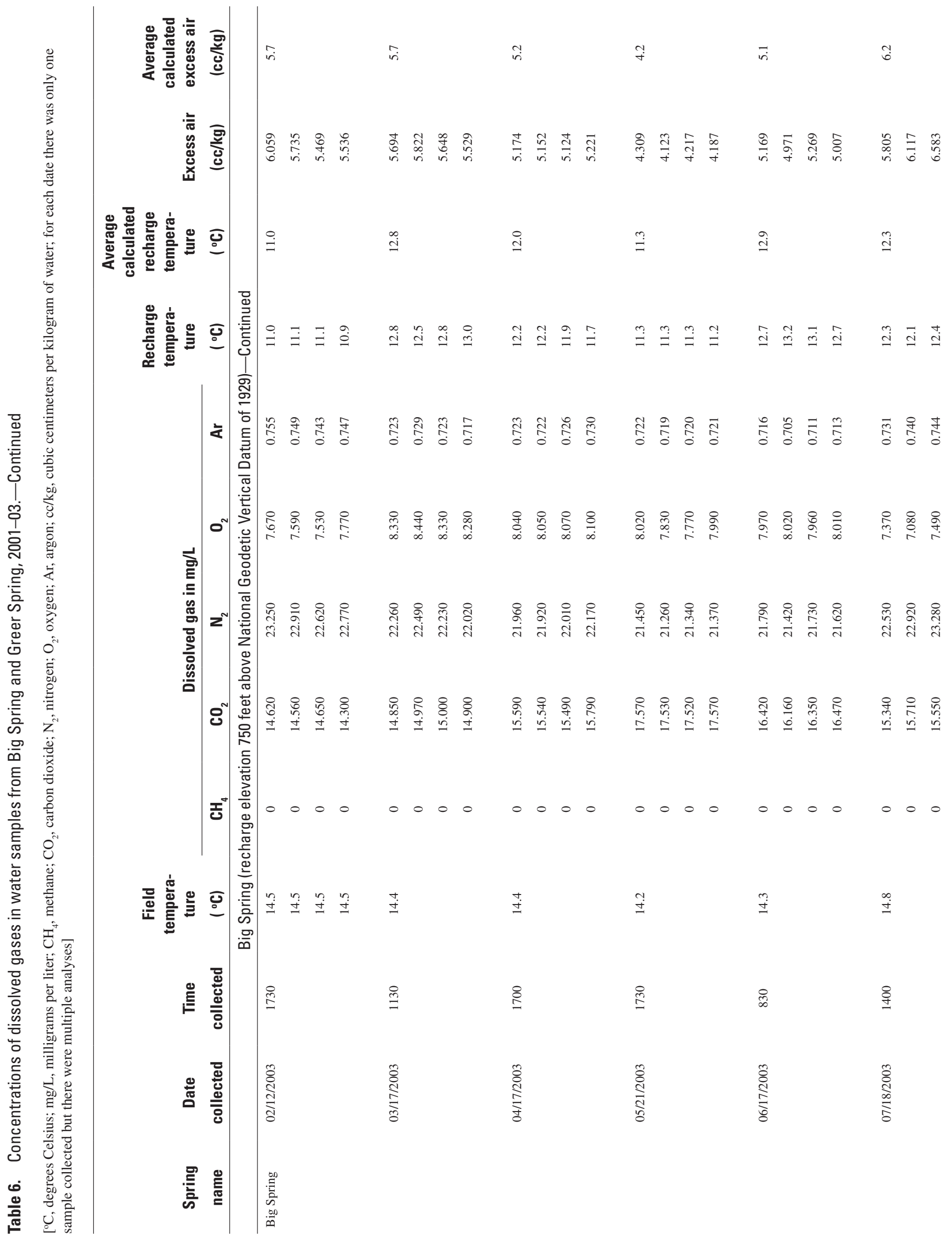




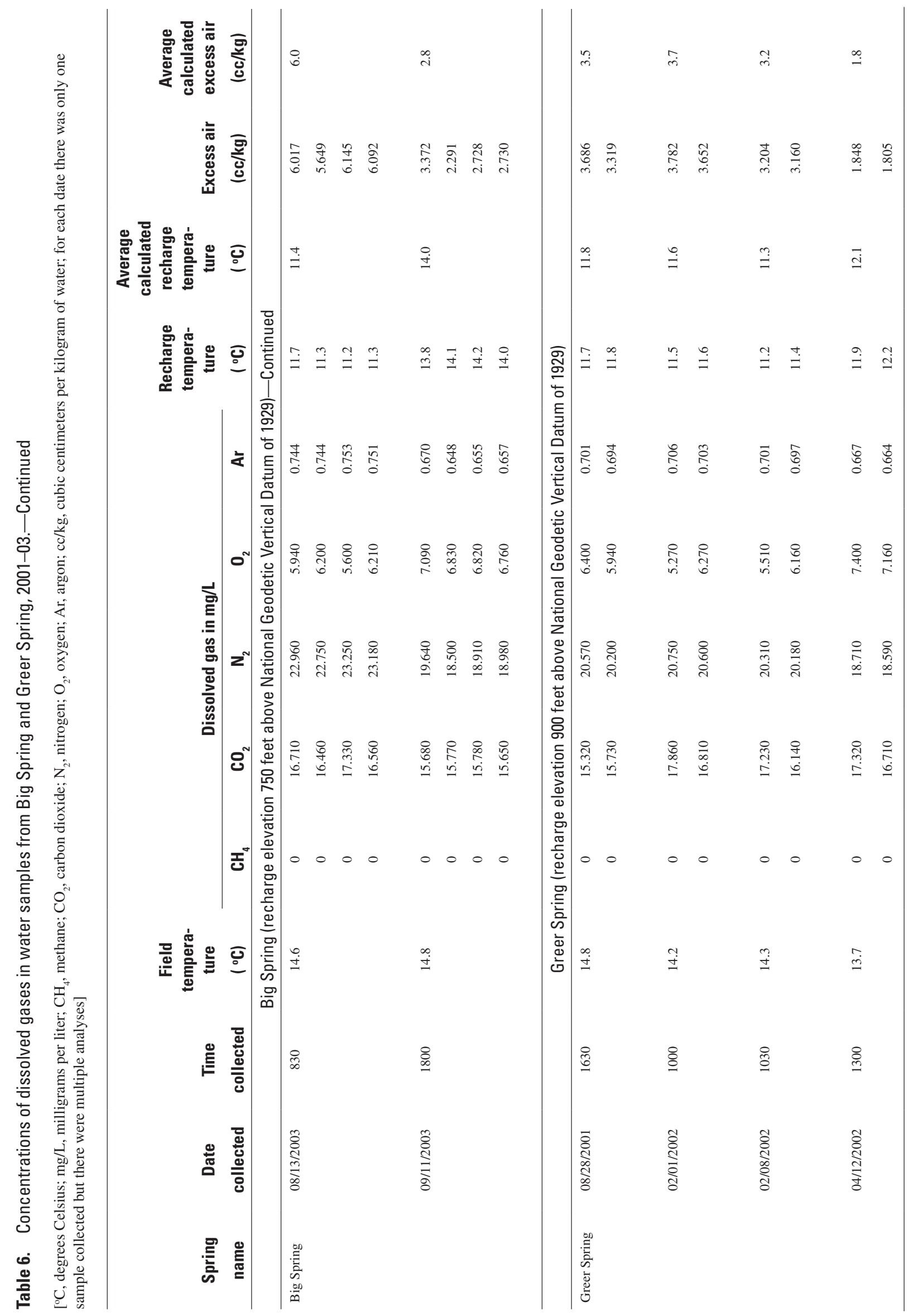




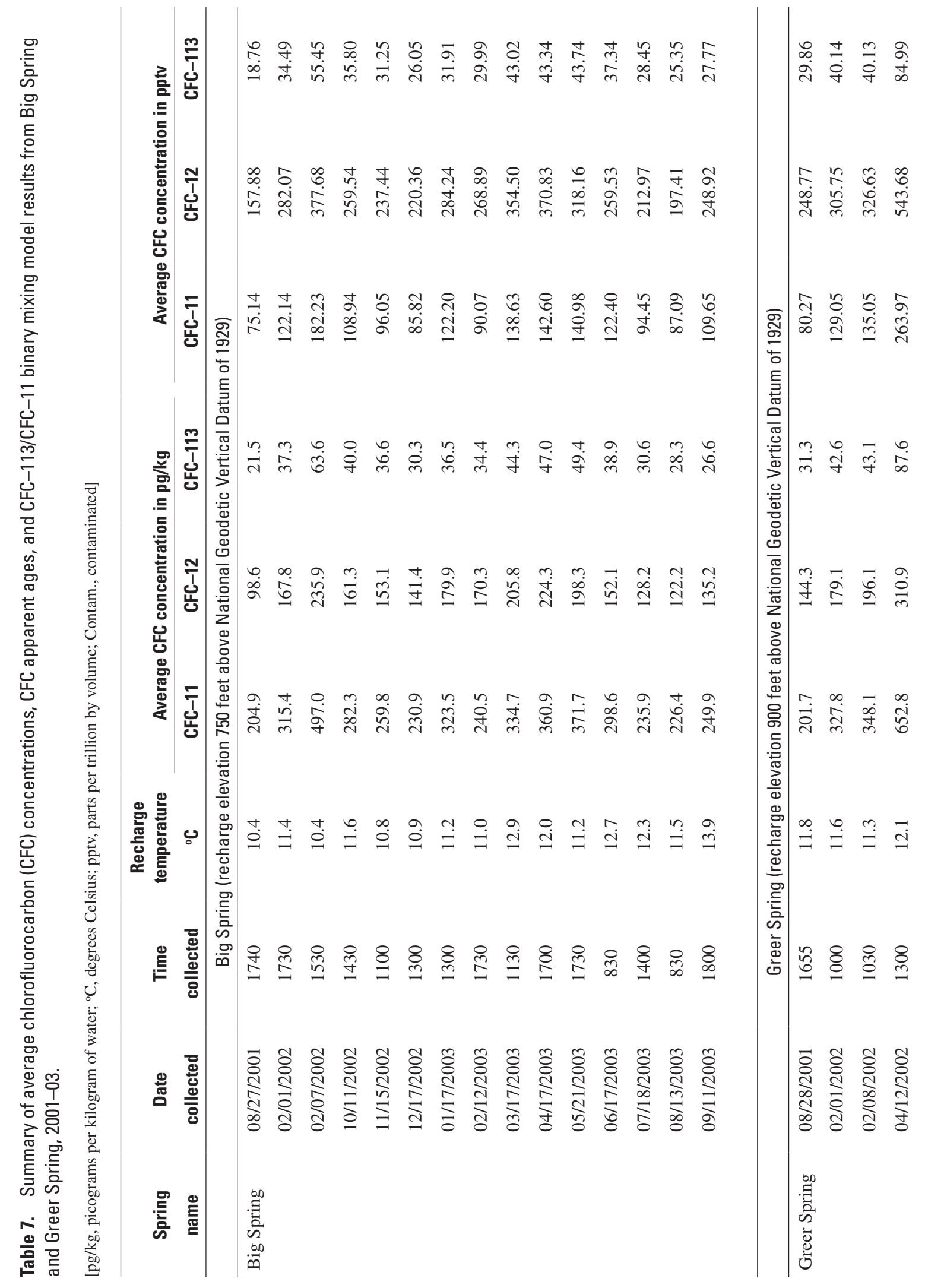



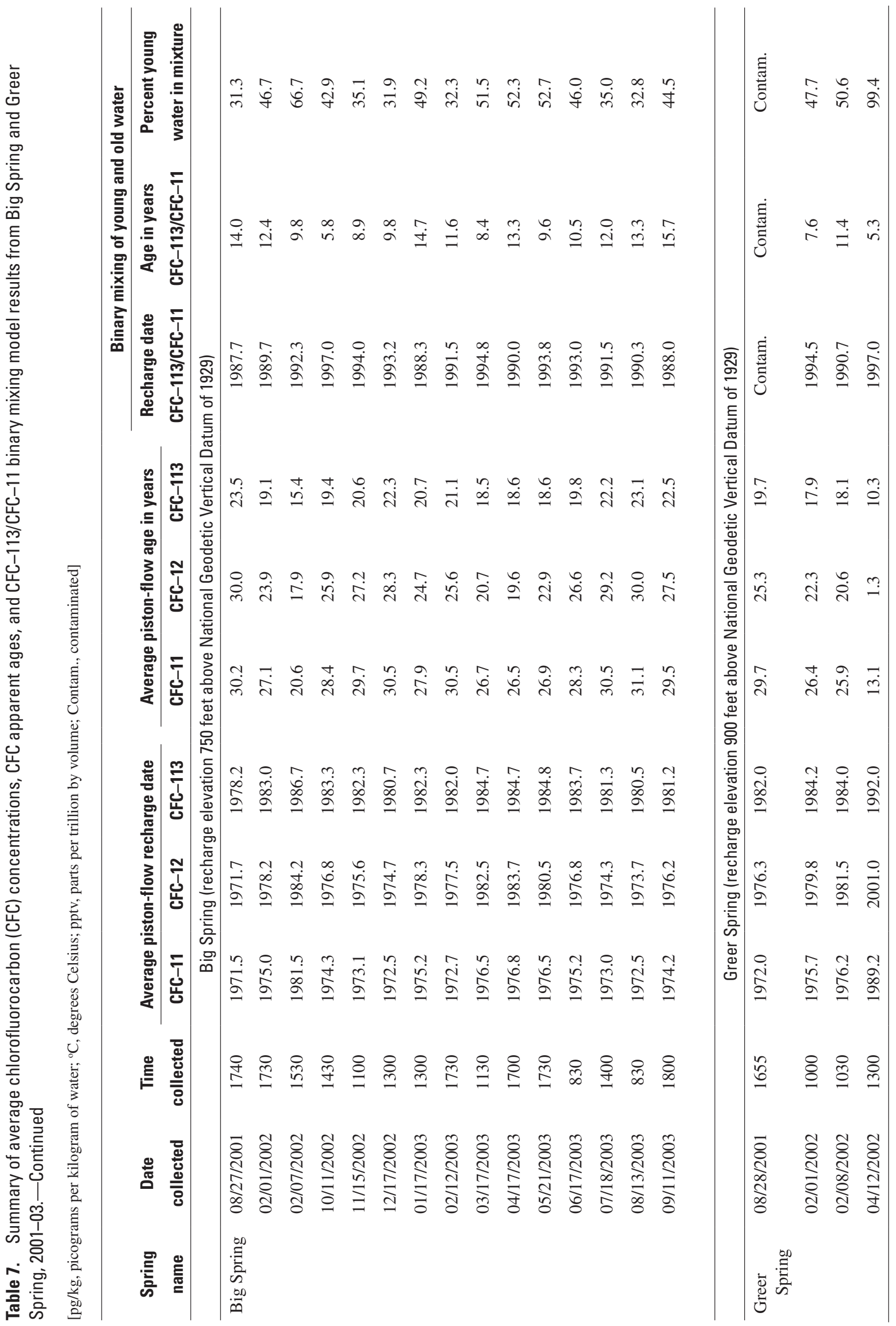


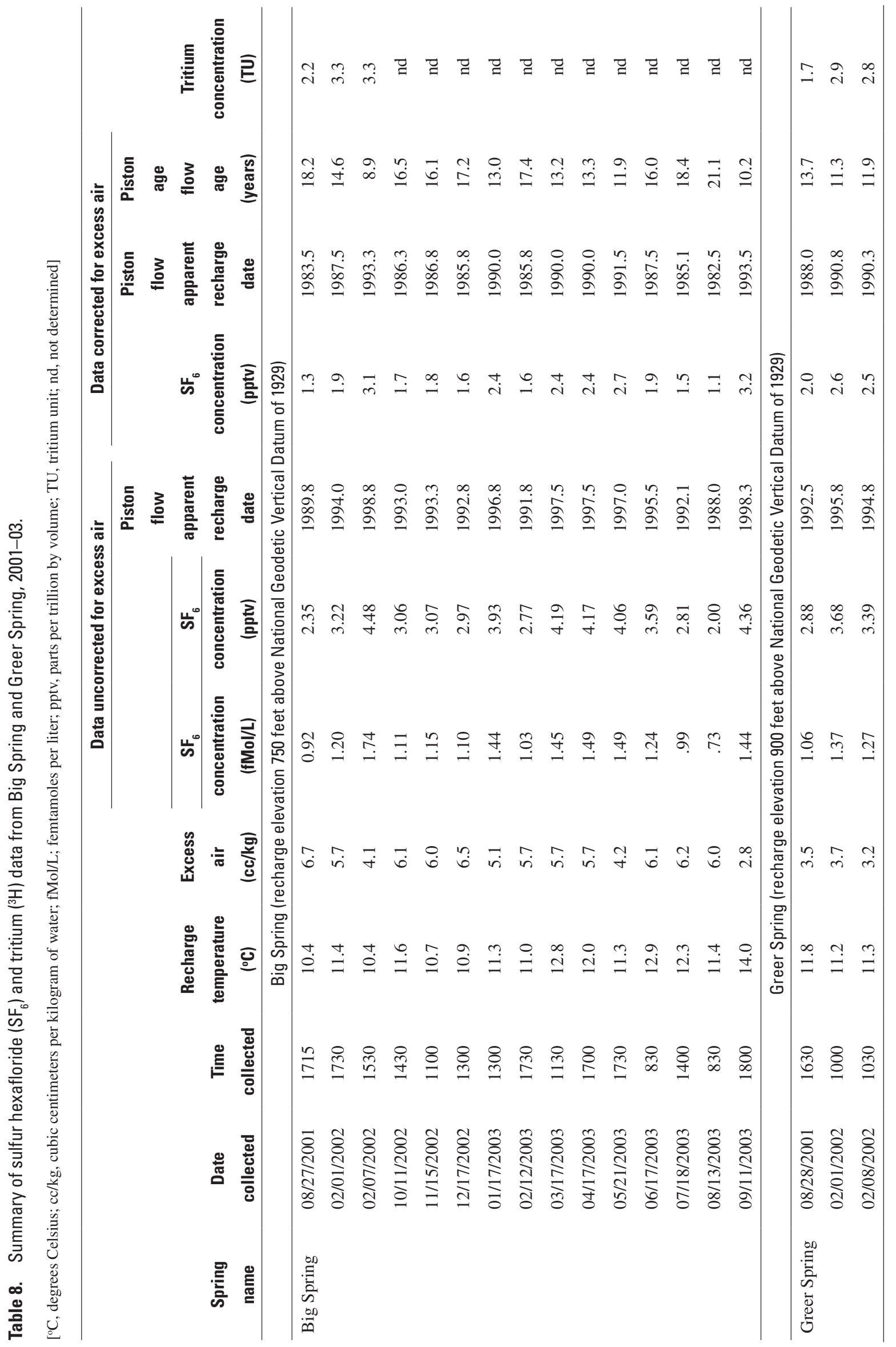




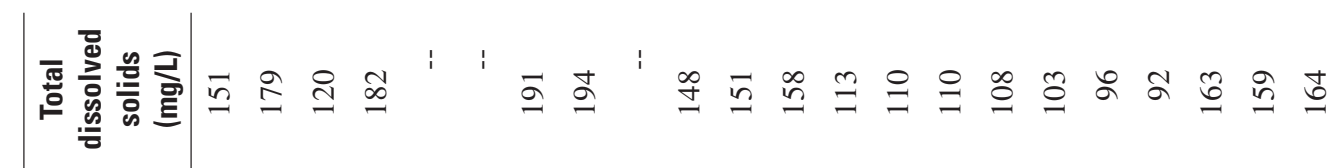

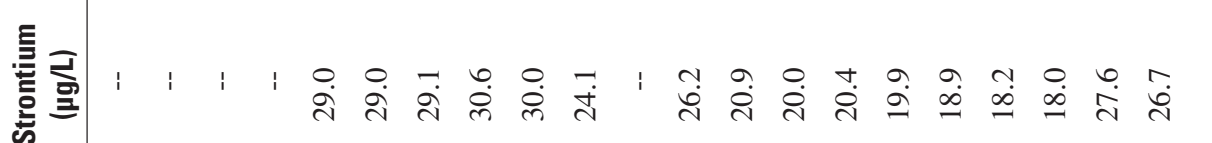

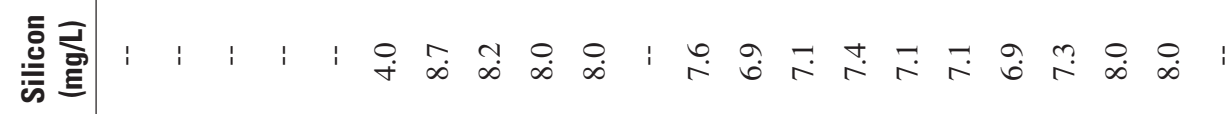

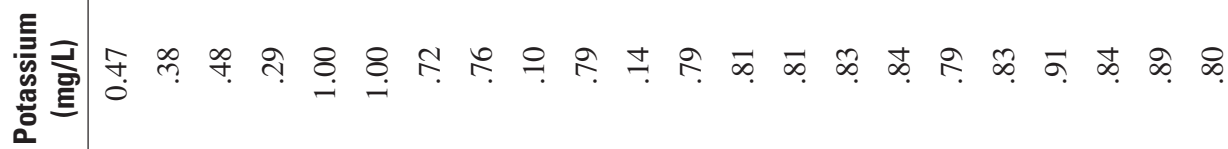

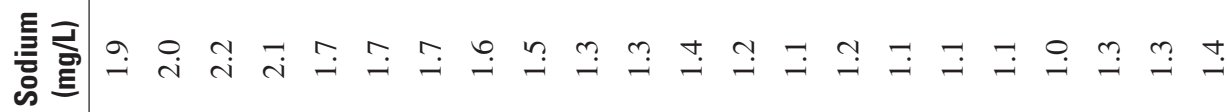
喜

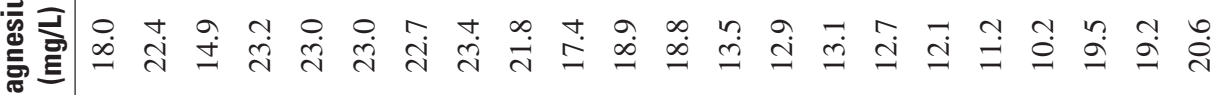

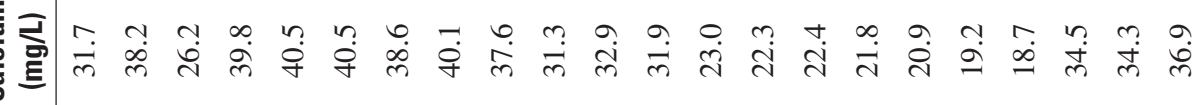
衰产

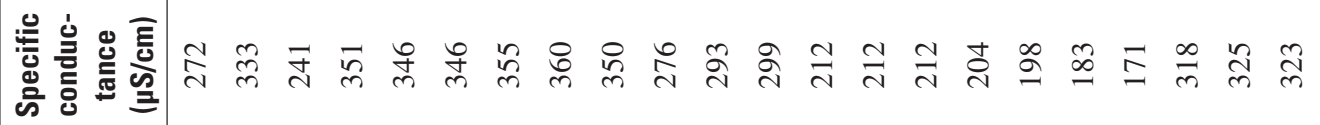

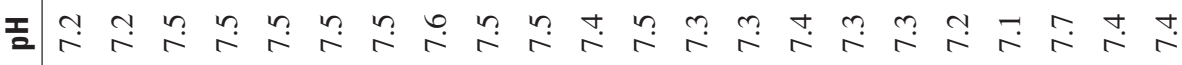

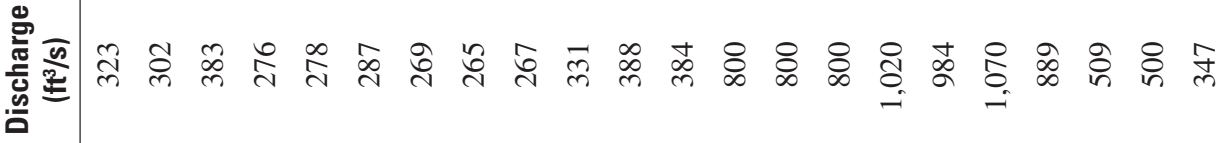

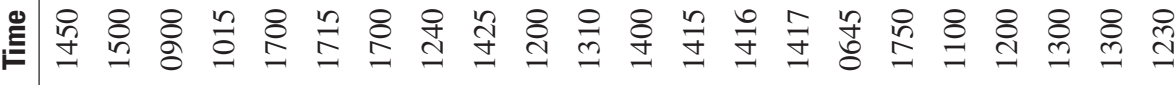

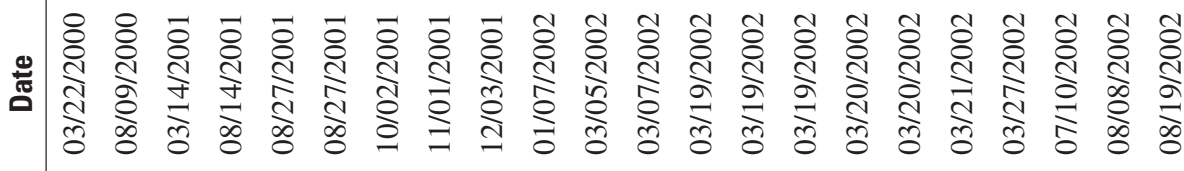




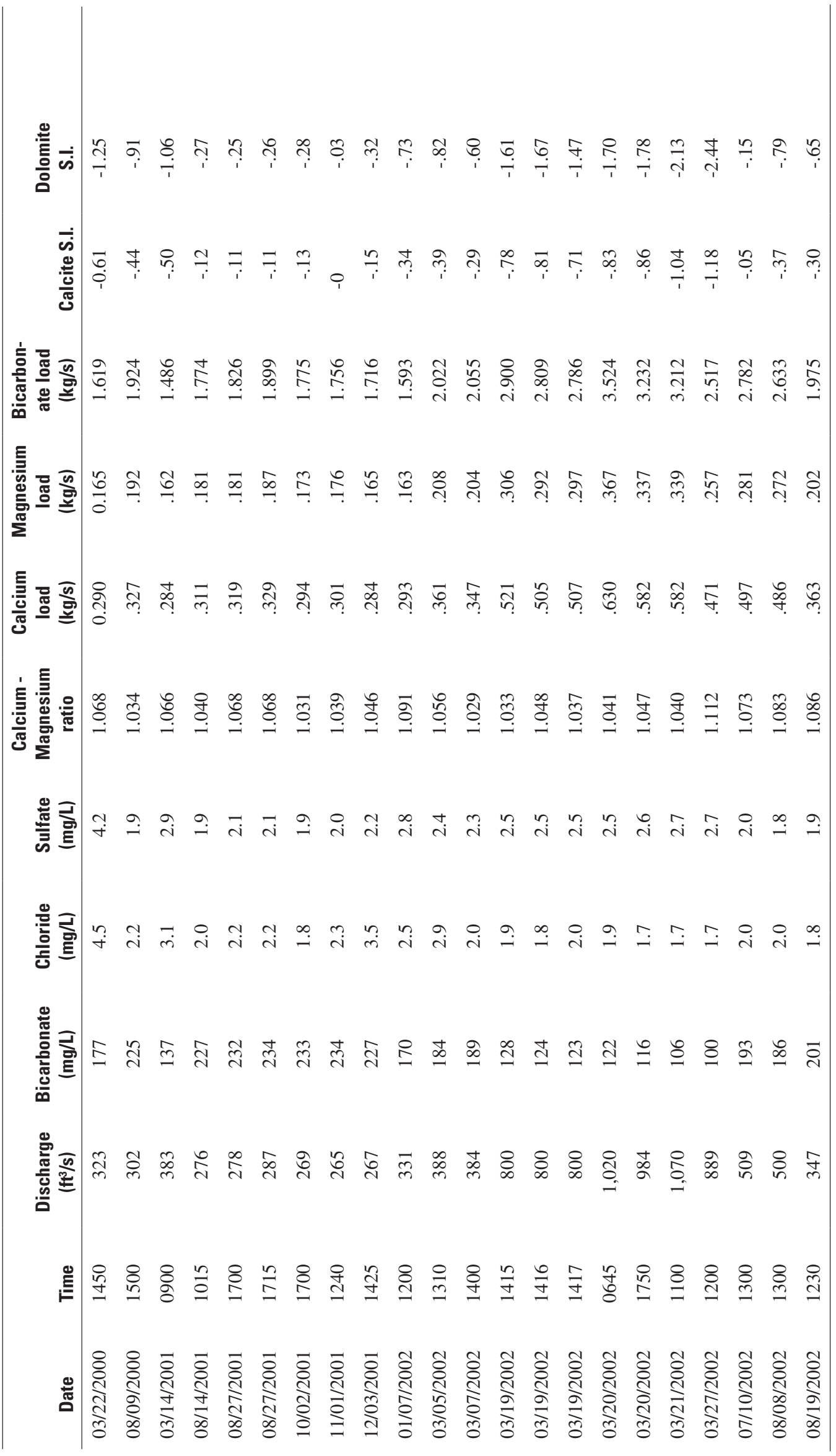


Table 10. Suspended sediment concentrations and sediment load of water discharging from Big Spring, 2001-04.

[ft³/s, cubic feet per second; mg/L, milligram per liter; EWI, equal width increment; TDS, total dissolved solids; --, no data]

\begin{tabular}{|c|c|c|c|c|c|c|c|c|c|}
\hline \multirow[b]{2}{*}{ Date } & \multirow[b]{2}{*}{ Time } & \multirow[b]{2}{*}{$\begin{array}{l}\text { Discharge } \\
\qquad\left(\mathrm{ft}^{3} / \mathrm{s}\right)\end{array}$} & \multirow[b]{2}{*}{$\begin{array}{c}\text { Total } \\
\text { dissolved } \\
\text { solids } 1 \\
\text { (mg/L) }\end{array}$} & \multicolumn{3}{|c|}{$\begin{array}{c}\text { EWI collection method } \\
\text { (corrected for TDS where necessary) }\end{array}$} & \multicolumn{3}{|c|}{$\begin{array}{l}\text { Point sampler collection method } \\
\text { (corrected for TDS where necessary) }\end{array}$} \\
\hline & & & & $\begin{array}{c}\text { Sediment } \\
\text { concen- } \\
\text { tration } \\
\text { (mg/L) }\end{array}$ & $\begin{array}{c}\text { Sediment } \\
\text { concen- } \\
\text { tration }^{2} \\
\text { (mg/L) }\end{array}$ & $\begin{array}{c}\text { Sediment } \\
\text { load } \\
\text { (tons/day) }\end{array}$ & $\begin{array}{c}\text { Sediment } \\
\text { concen- } \\
\text { tration } \\
\text { (mg/L) }\end{array}$ & $\begin{array}{c}\text { Sediment } \\
\text { concen- } \\
\text { tration }^{2} \\
(\mathrm{mg} / \mathrm{L})\end{array}$ & $\begin{array}{c}\text { Sediment } \\
\text { load } \\
\text { (tons/day) }\end{array}$ \\
\hline $02 / 07 / 2001$ & 1300 & 294 & 184 & 24 & 7 & 6 & -- & -- & -- \\
\hline $02 / 08 / 2001$ & 1400 & 295 & 183 & -- & -- & -- & 19 & 2 & 2 \\
\hline $02 / 24 / 2001$ & 1902 & 479 & 158 & -- & -- & -- & 17 & 3 & 4 \\
\hline $02 / 26 / 2001$ & 1520 & 730 & 143 & 29 & 16 & 32 & 24 & 11 & 22 \\
\hline $02 / 26 / 2001$ & 1902 & 720 & 143 & -- & -- & -- & 22 & 9 & 18 \\
\hline $02 / 28 / 2001$ & 1529 & 650 & 137 & -- & -- & -- & 19 & 7 & 12 \\
\hline 03/02/2001 & 1340 & 539 & 133 & -- & -- & -- & 20 & 8 & 12 \\
\hline 03/07/2001 & 1400 & 430 & 116 & -- & -- & -- & 16 & 6 & 6 \\
\hline 09/11/2001 & 1315 & 283 & 185 & 35 & 18 & 14 & -- & -- & -- \\
\hline $10 / 02 / 2001$ & 1700 & 264 & 184 & 31 & 14 & 10 & -- & -- & -- \\
\hline $11 / 01 / 2001$ & 1240 & 272 & 185 & 29 & 12 & 9 & -- & -- & -- \\
\hline $12 / 17 / 2001$ & 1330 & 800 & 179 & 42 & 26 & 56 & -- & -- & -- \\
\hline $12 / 18 / 2001$ & 1230 & 750 & 159 & 38 & 24 & 48 & -- & -- & -- \\
\hline $01 / 07 / 2002$ & 1200 & 330 & 145 & 16 & 3 & 3 & -- & -- & -- \\
\hline 03/07/2002 & 1540 & 383 & 158 & 26 & 12 & 12 & 16 & 2 & 2 \\
\hline 03/19/2002 & 1415 & 812 & 111 & 16 & 6 & 13 & 12 & 2 & 4 \\
\hline 03/19/2002 & 1926 & 999 & 111 & 21 & 11 & 30 & 17 & 7 & 19 \\
\hline $03 / 20 / 2002$ & 0326 & 1010 & 109 & -- & -- & -- & 22 & 12 & 33 \\
\hline 03/20/2002 & 0645 & 1020 & 107 & 27 & 17 & 48 & 24 & 14 & 39 \\
\hline 03/20/2002 & 1239 & 1000 & 106 & 31 & 21 & 58 & 29 & 19 & 52 \\
\hline 03/20/2002 & 1724 & 1020 & 103 & 31 & 22 & 60 & 32 & 23 & 62 \\
\hline 03/20/2002 & 2149 & 1050 & 101 & -- & -- & -- & 26 & 17 & 48 \\
\hline 03/20/2002 & 2324 & 1050 & 101 & -- & -- & -- & 30 & 21 & 59 \\
\hline $03 / 21 / 2002$ & 0524 & 1060 & 101 & -- & -- & -- & 29 & 20 & 57 \\
\hline $03 / 21 / 2002$ & 1123 & 1070 & 96 & 33 & 24 & 70 & 32 & 23 & 67 \\
\hline $03 / 21 / 2002$ & 1723 & 1040 & 93 & -- & -- & -- & 29 & 21 & 58 \\
\hline $03 / 21 / 2002$ & 2323 & 1020 & 91 & -- & -- & -- & 30 & 22 & 60 \\
\hline $03 / 22 / 2002$ & 0523 & 1010 & 91 & -- & -- & -- & 26 & 18 & 49 \\
\hline $03 / 22 / 2002$ & 1045 & 1000 & 89 & 30 & 22 & 59 & -- & -- & -- \\
\hline $03 / 27 / 2002$ & 1142 & 900 & 89 & 21 & 13 & 32 & 19 & 11 & 27 \\
\hline $03 / 28 / 2002$ & 1746 & 815 & 87 & -- & -- & -- & 17 & 9 & 20 \\
\hline $04 / 03 / 2002$ & 2346 & 586 & 97 & -- & -- & -- & 14 & 5 & 8 \\
\hline $04 / 07 / 2002$ & 1746 & 576 & 106 & -- & -- & -- & 13 & 3 & 5 \\
\hline $04 / 08 / 2002$ & 2346 & 790 & 114 & -- & -- & -- & 19 & 9 & 19 \\
\hline $04 / 10 / 2002$ & 0546 & 940 & 115 & -- & -- & -- & 17 & 7 & 17 \\
\hline $04 / 11 / 2002$ & 1146 & 803 & 106 & -- & -- & -- & 17 & 7 & 16 \\
\hline $04 / 12 / 2002$ & 1746 & 685 & 107 & -- & -- & -- & 17 & 7 & 14 \\
\hline $04 / 13 / 2002$ & 2346 & 708 & 105 & -- & -- & -- & 17 & 8 & 14 \\
\hline $04 / 15 / 2002$ & 0546 & 900 & 103 & -- & -- & -- & 15 & 6 & 14 \\
\hline $04 / 17 / 2002$ & 1400 & 770 & 97 & 25 & 16 & 34 & 16 & 7 & 15 \\
\hline $04 / 18 / 2002$ & 1746 & 699 & 100 & -- & -- & -- & 13 & 4 & 8 \\
\hline $04 / 23 / 2002$ & 1939 & 613 & 108 & -- & -- & -- & 14 & 4 & 7 \\
\hline
\end{tabular}


Table 10. Suspended sediment concentrations and sediment load of water discharging from Big Spring, 2001-04.-Continued $\left[\mathrm{ft}^{3} / \mathrm{s}\right.$, cubic feet per second; mg/L, milligram per liter; EWI, equal width increment; TDS, total dissolved solids; --, no data]

\begin{tabular}{|c|c|c|c|c|c|c|c|c|c|}
\hline \multirow[b]{2}{*}{ Date } & \multirow[b]{2}{*}{ Time } & \multirow[b]{2}{*}{$\begin{array}{l}\text { Discharge } \\
\quad\left(\mathrm{ft}^{3} / \mathrm{s}\right)\end{array}$} & \multirow[b]{2}{*}{$\begin{array}{c}\text { Total } \\
\text { dissolved } \\
\text { solids }^{1} \\
\text { (mg/L) }\end{array}$} & \multicolumn{3}{|c|}{$\begin{array}{c}\text { EWI collection method } \\
\text { (corrected for TDS where necessary) }\end{array}$} & \multicolumn{3}{|c|}{$\begin{array}{c}\text { Point sampler collection method } \\
\text { (corrected for TDS where necessary) }\end{array}$} \\
\hline & & & & $\begin{array}{c}\text { Sediment } \\
\text { concen- } \\
\text { tration } \\
\text { (mg/L) }\end{array}$ & $\begin{array}{c}\text { Sediment } \\
\text { concen- } \\
\text { tration }{ }^{2} \\
\text { (mg/L) }\end{array}$ & $\begin{array}{l}\text { Sediment } \\
\text { load } \\
\text { (tons/day) }\end{array}$ & $\begin{array}{c}\text { Sediment } \\
\text { concen- } \\
\text { tration } \\
\text { (mg/L) }\end{array}$ & $\begin{array}{c}\text { Sediment } \\
\text { concen- } \\
\text { tration }{ }^{2} \\
(\mathrm{mg} / \mathrm{L})\end{array}$ & $\begin{array}{c}\text { Sediment } \\
\text { load } \\
\text { (tons/day) }\end{array}$ \\
\hline $04 / 25 / 2002$ & 0139 & 750 & 113 & -- & -- & -- & 15 & 5 & 10 \\
\hline $04 / 27 / 2002$ & 1339 & 668 & 115 & -- & -- & -- & 20 & 10 & 17 \\
\hline $04 / 28 / 2002$ & 1939 & 629 & 117 & -- & -- & -- & 15 & 4 & 8 \\
\hline 05/06/2002 & 0739 & 552 & 132 & -- & -- & -- & 47 & 35 & 52 \\
\hline 05/07/2002 & 1339 & 557 & 133 & -- & -- & -- & 16 & 4 & 6 \\
\hline 05/13/2002 & 1430 & 1100 & 107 & 31 & 21 & 63 & -- & -- & -- \\
\hline 06/11/2002 & 0830 & 635 & 140 & 31 & 18 & 31 & 3 & 3 & 5 \\
\hline 06/20/2002 & 0043 & 570 & -- & -- & -- & -- & 6 & 6 & 9 \\
\hline $07 / 08 / 2002$ & 1843 & 509 & -- & -- & -- & -- & 2 & 2 & 3 \\
\hline 07/10/2002 & 1130 & 514 & -- & 2 & 2 & 3 & 5 & 5 & 7 \\
\hline 07/19/2002 & 0530 & 517 & -- & -- & -- & -- & 9 & 9 & 13 \\
\hline 07/20/2002 & 1130 & 527 & -- & -- & -- & -- & 9 & 9 & 13 \\
\hline $07 / 21 / 2002$ & 1730 & 532 & -- & -- & -- & -- & 4 & 4 & 6 \\
\hline $07 / 22 / 2002$ & 2330 & 499 & -- & -- & -- & -- & 11 & 11 & 15 \\
\hline 07/30/2002 & 1130 & 482 & -- & -- & -- & -- & 5 & 5 & 6 \\
\hline 08/08/2002 & 1300 & 458 & -- & 5 & 5 & 6 & 12 & 12 & 15 \\
\hline 08/13/2002 & 1110 & 456 & -- & -- & -- & -- & 1 & 1 & 1 \\
\hline $08 / 14 / 2002$ & 1710 & 461 & -- & -- & -- & -- & 14 & 14 & 17 \\
\hline $08 / 23 / 2002$ & 1110 & 444 & -- & -- & -- & -- & 17 & 17 & 20 \\
\hline $08 / 27 / 2002$ & 1330 & 440 & -- & -- & -- & -- & 2 & 2 & 2 \\
\hline 09/05/2002 & 1400 & 435 & -- & -- & -- & -- & 6 & 6 & 7 \\
\hline 09/05/2002 & 1210 & 435 & -- & -- & -- & -- & 1 & 1 & 1 \\
\hline $10 / 03 / 2002$ & 1345 & 358 & -- & 2 & 2 & 2 & 1 & 1 & 1 \\
\hline $10 / 18 / 2002$ & 2245 & 348 & -- & -- & -- & -- & 2 & 2 & 2 \\
\hline $10 / 30 / 2002$ & 0445 & 342 & -- & -- & -- & -- & 4 & 4 & 4 \\
\hline $11 / 15 / 2002$ & 0845 & 344 & -- & 1 & 1 & 1 & -- & -- & -- \\
\hline $11 / 22 / 2002$ & 2002 & 338 & -- & -- & -- & -- & 2 & 2 & 2 \\
\hline $12 / 04 / 2002$ & 0202 & 342 & -- & -- & -- & -- & 12 & 12 & 11 \\
\hline $12 / 17 / 2002$ & 1130 & 338 & -- & 2 & 2 & 2 & 9 & 9 & 8 \\
\hline $12 / 23 / 2002$ & 1730 & 335 & -- & -- & -- & -- & 3 & 3 & 3 \\
\hline $12 / 31 / 2002$ & 0530 & 364 & -- & -- & -- & -- & 1 & 1 & 1 \\
\hline 01/01/2003 & 1130 & 600 & -- & -- & -- & -- & 1 & 1 & 2 \\
\hline $01 / 02 / 2003$ & 1730 & 500 & -- & -- & -- & -- & 2 & 2 & 3 \\
\hline $01 / 03 / 2003$ & 2330 & 442 & -- & -- & -- & -- & 2 & 2 & 2 \\
\hline $01 / 10 / 2003$ & 0530 & 367 & -- & -- & -- & -- & 10 & 10 & 10 \\
\hline $01 / 16 / 2003$ & 1415 & 352 & -- & 1 & 1 & 1 & 15 & 15 & 14 \\
\hline $01 / 22 / 2003$ & 2253 & 333 & -- & -- & -- & -- & 4 & 4 & 4 \\
\hline $02 / 01 / 2003$ & 2253 & 325 & -- & -- & -- & -- & 1 & 1 & 1 \\
\hline 02/09/2003 & 1053 & 318 & -- & -- & -- & -- & 1 & 1 & 1 \\
\hline $02 / 12 / 2003$ & 1600 & 314 & -- & 1 & 1 & 1 & 1 & 1 & 1 \\
\hline $02 / 15 / 2003$ & 0306 & 381 & -- & -- & -- & -- & 2 & 2 & 2 \\
\hline $02 / 16 / 2003$ & 0906 & 401 & -- & -- & -- & -- & 1 & 1 & 1 \\
\hline
\end{tabular}


Table 10. Suspended sediment concentrations and sediment load of water discharging from Big Spring, 2001-04.—Continued [ft³/s, cubic feet per second; mg/L, milligram per liter; EWI, equal width increment; TDS, total dissolved solids; --, no data]

\begin{tabular}{|c|c|c|c|c|c|c|c|c|c|}
\hline \multirow[b]{2}{*}{ Date } & \multirow[b]{2}{*}{ Time } & \multirow[b]{2}{*}{$\begin{array}{c}\text { Discharge } \\
\left(\mathrm{ft}^{3} / \mathbf{s}\right)\end{array}$} & \multirow[b]{2}{*}{$\begin{array}{c}\text { Total } \\
\text { dissolved } \\
\text { solids } \\
\text { (mg/L) }\end{array}$} & \multicolumn{3}{|c|}{$\begin{array}{c}\text { EWI collection method } \\
\text { (corrected for TDS where necessary) }\end{array}$} & \multicolumn{3}{|c|}{$\begin{array}{l}\text { Point sampler collection method } \\
\text { (corrected for TDS where necessary) }\end{array}$} \\
\hline & & & & $\begin{array}{c}\text { Sediment } \\
\text { concen- } \\
\text { tration } \\
\text { (mg/L) }\end{array}$ & $\begin{array}{c}\text { Sediment } \\
\text { concen- } \\
\text { tration } \\
\text { (mg/L) }\end{array}$ & $\begin{array}{c}\text { Sediment } \\
\text { load } \\
\text { (tons/day) }\end{array}$ & $\begin{array}{c}\text { Sediment } \\
\text { concen- } \\
\text { tration } \\
(\mathrm{mg} / \mathrm{L})\end{array}$ & $\begin{array}{c}\text { Sediment } \\
\text { concen- } \\
\text { tration }^{2} \\
(\mathrm{mg} / \mathrm{L})\end{array}$ & $\begin{array}{c}\text { Sediment } \\
\text { load } \\
\text { (tons/day) }\end{array}$ \\
\hline $02 / 18 / 2003$ & 2106 & 354 & -- & -- & -- & -- & 1 & 1 & 1 \\
\hline $02 / 20 / 2003$ & 0306 & 419 & -- & -- & -- & -- & 1 & 1 & 1 \\
\hline $02 / 21 / 2003$ & 0906 & 460 & -- & -- & -- & -- & 3 & 3 & 4 \\
\hline $02 / 25 / 2003$ & 0306 & 425 & -- & -- & -- & -- & 2 & 2 & 2 \\
\hline $03 / 04 / 2003$ & 1506 & 379 & -- & -- & -- & -- & 1 & 1 & 1 \\
\hline 03/09/2003 & 1506 & 358 & -- & -- & -- & -- & 2 & 2 & 2 \\
\hline $03 / 14 / 2003$ & 0830 & 352 & -- & 1 & 1 & 1 & 2 & 2 & 2 \\
\hline 04/06/2003 & 0705 & 367 & -- & -- & -- & -- & 2 & 2 & 2 \\
\hline $04 / 07 / 2003$ & 1305 & 412 & -- & -- & -- & -- & 3 & 3 & 3 \\
\hline $04 / 08 / 2003$ & 0405 & 437 & -- & -- & -- & -- & 2 & 2 & 2 \\
\hline 04/10/2003 & 1605 & 419 & -- & -- & -- & -- & 1 & 1 & 1 \\
\hline $04 / 13 / 2003$ & 1905 & 388 & -- & -- & -- & -- & 1 & 1 & 1 \\
\hline $04 / 17 / 2003$ & 1305 & 377 & -- & 1 & 1 & 1 & 1 & 1 & 1 \\
\hline $04 / 23 / 2003$ & 2010 & 369 & -- & -- & -- & -- & 2 & 2 & 2 \\
\hline $04 / 25 / 2003$ & 1710 & 403 & -- & -- & -- & -- & 1 & 1 & 1 \\
\hline $04 / 26 / 2003$ & 0810 & 560 & -- & -- & -- & -- & 2 & 2 & 3 \\
\hline $04 / 26 / 2003$ & 2310 & 550 & -- & -- & -- & -- & 2 & 2 & 3 \\
\hline $04 / 28 / 2003$ & 2010 & 430 & -- & -- & -- & -- & 4 & 4 & 5 \\
\hline 05/10/2003 & 0011 & 449 & -- & -- & -- & -- & 2 & 2 & 2 \\
\hline $05 / 16 / 2003$ & 0011 & 426 & -- & 4 & 4 & 5 & 1 & 1 & 1 \\
\hline $05 / 17 / 2003$ & 1211 & 506 & -- & -- & -- & -- & 0 & 0 & 0 \\
\hline $05 / 22 / 2003$ & 0820 & 477 & -- & -- & -- & -- & 2 & 2 & 3 \\
\hline $05 / 31 / 2003$ & 0820 & 390 & -- & -- & -- & -- & 3 & 3 & 3 \\
\hline 06/10/2003 & 2330 & 362 & -- & -- & -- & -- & 1 & 1 & 1 \\
\hline $06 / 13 / 2003$ & 0530 & 379 & -- & -- & -- & -- & 6 & 6 & 6 \\
\hline $06 / 13 / 2003$ & 2330 & 394 & -- & -- & -- & -- & 1 & 1 & 1 \\
\hline $06 / 16 / 2003$ & 1747 & 369 & -- & 2 & 2 & 2 & 1 & 1 & 1 \\
\hline 06/28/2003 & 1747 & 346 & -- & -- & -- & -- & 2 & 2 & 2 \\
\hline 07/08/2003 & 0605 & 331 & -- & -- & -- & -- & 1 & 1 & 1 \\
\hline $08 / 12 / 2003$ & 1730 & 312 & -- & 1 & 1 & 1 & 1 & 1 & 1 \\
\hline 08/22/2003 & 1730 & 306 & -- & -- & -- & -- & 1 & 1 & 1 \\
\hline 08/28/2003 & 2330 & 298 & -- & -- & -- & -- & 1 & 1 & 1 \\
\hline 08/31/2003 & 1130 & 335 & -- & -- & -- & -- & 1 & 1 & 1 \\
\hline 09/02/2003 & 2330 & 421 & -- & -- & -- & -- & 1 & 1 & 1 \\
\hline $09 / 11 / 2003$ & 1630 & 342 & -- & 2 & 2 & 2 & -- & -- & -- \\
\hline $11 / 13 / 2003$ & 1545 & 306 & 178 & 14 & -2 & -2 & -- & -- & -- \\
\hline $11 / 18 / 2003$ & 1300 & 776 & 183 & 31 & 14 & 30 & -- & -- & -- \\
\hline $11 / 20 / 2003$ & 1500 & 859 & 151 & 44 & 30 & 70 & -- & -- & -- \\
\hline $02 / 06 / 2004$ & 0930 & 442 & 232 & -- & -- & -- & 25 & 4 & 5 \\
\hline
\end{tabular}

${ }^{1}$ TDS values are estimated from a linear regression relation of laboratory TDS values and specific conductance measurements. Values are entered only where TDS estimates are used to correct evaporation method laboratory analyses.

${ }^{2}$ Sediment analyses using the evaporation method (before June 20, 2002 and from November 2003 to February 2004) are corrected for the effect of TDS. 
For more information concerning the research described in this report, contact:

U.S. Geological Survey

Missouri Water Science Center

1400 Independence Road

Rolla, MO 65401

(573) 308-3667

http://mo.water.usgs.gov 



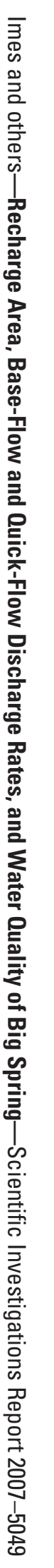

8 Printed on recycled paper 